ORNL/TM-2020/1707

Revision 0

\title{
Radial Deconsolidation and Leach-Burn-Leach of AGR-3/4 Compacts 1-4 and 10-4
}

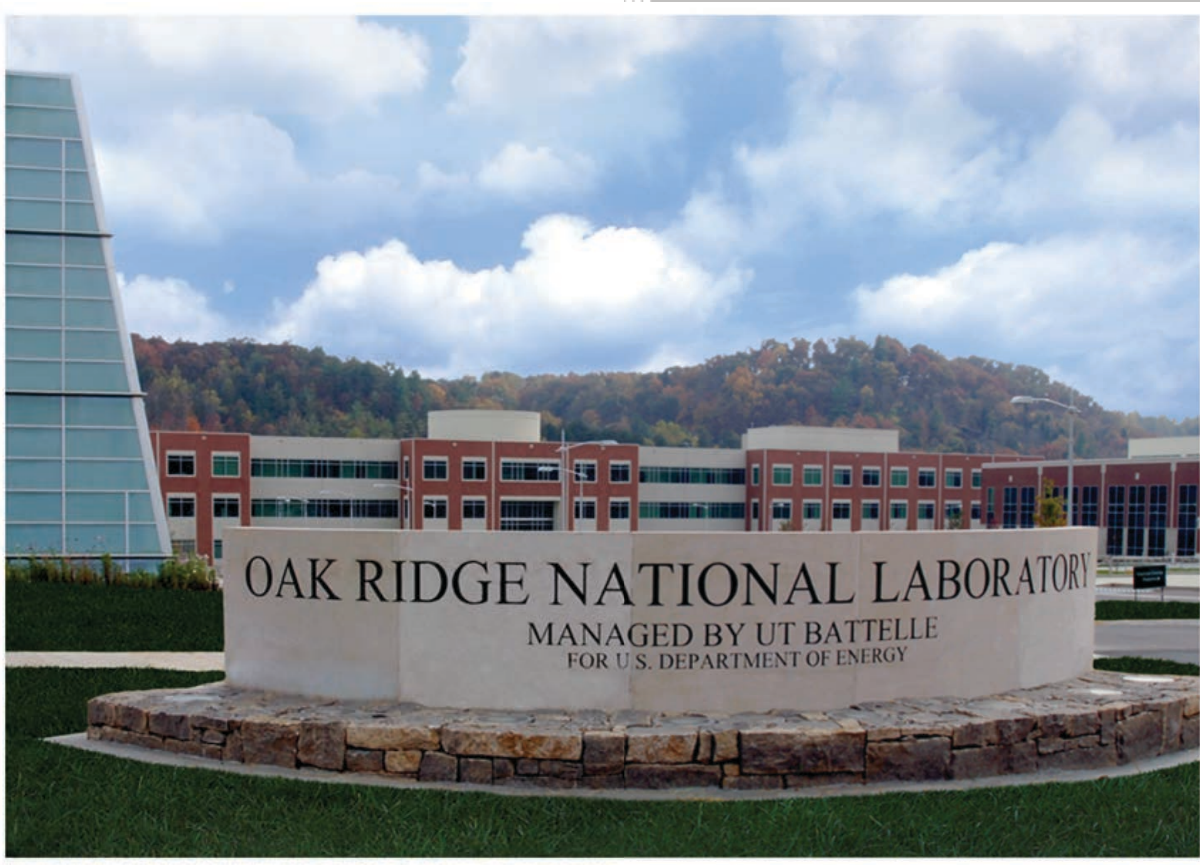

Approved for public release.

Distribution is unlimited.

John D. Hunn

Fred C. Montgomery

Darren J. Skitt

Grant W. Helmreich

September 2020 


\title{
DOCUMENT AVAILABILITY
}

Reports produced after January 1, 1996, are generally available free via US Department of Energy (DOE) SciTech Connect.

Website www.osti.gov

Reports produced before January 1, 1996, may be purchased by members of the public from the following source:

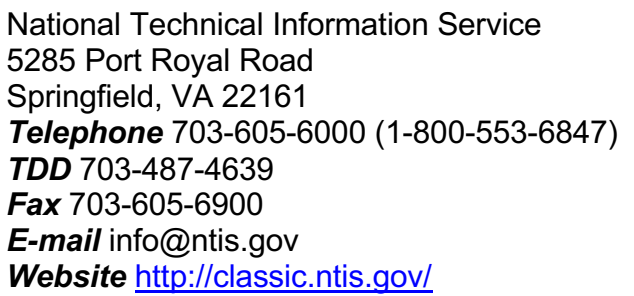

Reports are available to DOE employees, DOE contractors, Energy Technology Data Exchange representatives, and International Nuclear Information System representatives from the following source:

Office of Scientific and Technical Information

PO Box 62

Oak Ridge, TN 37831

Telephone 865-576-8401

Fax 865-576-5728

E-mail reports@osti.gov

Website http://www.osti.gov/contact.html

\begin{abstract}
This report was prepared as an account of work sponsored by an agency of the United States Government. Neither the United States Government nor any agency thereof, nor any of their employees, makes any warranty, express or implied, or assumes any legal liability or responsibility for the accuracy, completeness, or usefulness of any information, apparatus, product, or process disclosed, or represents that its use would not infringe privately owned rights. Reference herein to any specific commercial product, process, or service by trade name, trademark, manufacturer, or otherwise, does not necessarily constitute or imply its endorsement, recommendation, or favoring by the United States Government or any agency thereof. The views and opinions of authors expressed herein do not necessarily state or reflect those of the United States Government or any agency thereof.
\end{abstract}


ORNL/TM-2020/1707

Reactor and Nuclear Systems Division

\title{
RADIAL DECONSOLIDATION AND LEACH-BURN-LEACH OF AGR-3/4 COMPACTS 1-4 AND 10-4
}

\author{
John D. Hunn \\ Fred C. Montgomery \\ Darren J. Skitt \\ Grant W. Helmreich
}

Revision 0

Date Published: September 2020

\author{
Work sponsored by \\ US DEPARTMENT OF ENERGY \\ Office of Nuclear Energy_Advanced Reactor Technologies \\ under the
}

Advanced Gas Reactor Fuel Development and Qualification Program

Prepared by

OAK RIDGE NATIONAL LABORATORY

Oak Ridge, TN 37831-6283

managed by

UT-BATTELLE, LLC

for the

US DEPARTMENT OF ENERGY

under contract DE-AC05-00OR22725 



\section{CONTENTS}

REVISION LOG

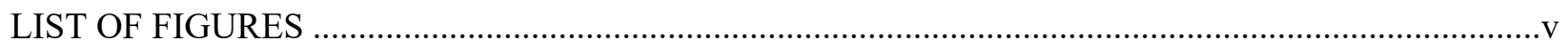

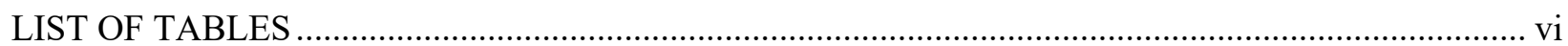

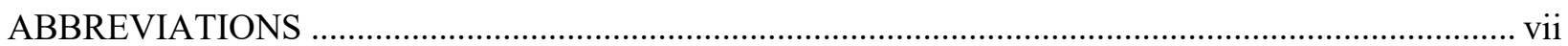

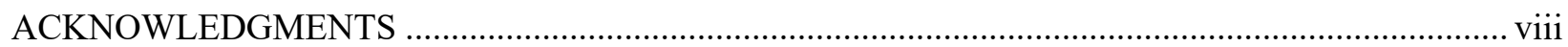

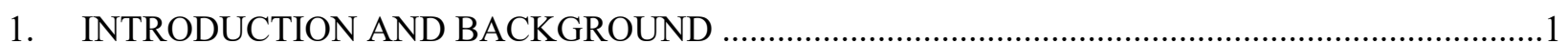

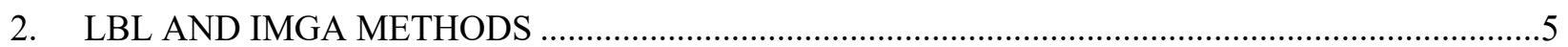

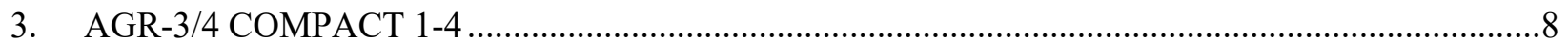

3.1 Radial Deconsolidation and Dimensional Analysis of Compact 1-4 …...............................

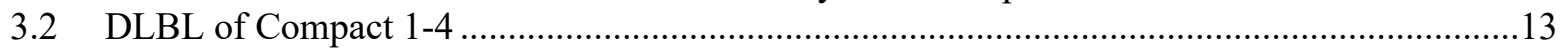

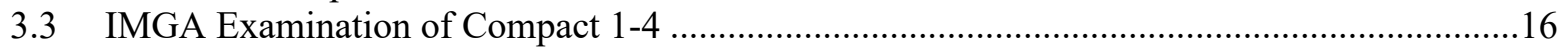

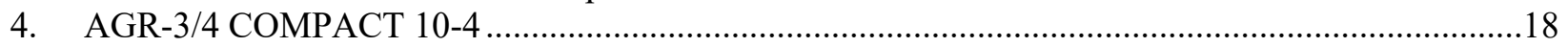

4.1 Radial Deconsolidation and Dimensional Analysis of Compact 10-4 ..................................18

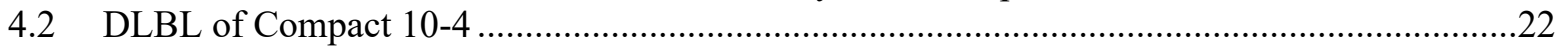

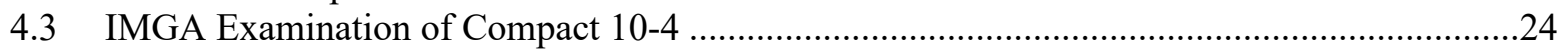

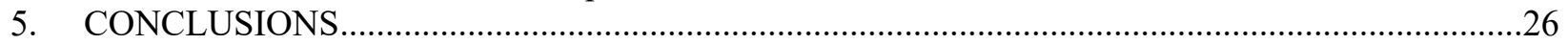

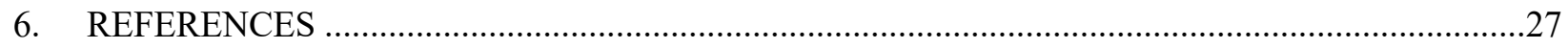

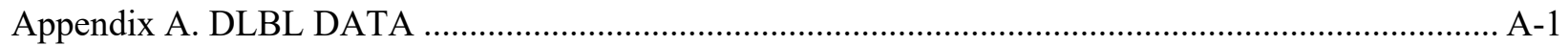

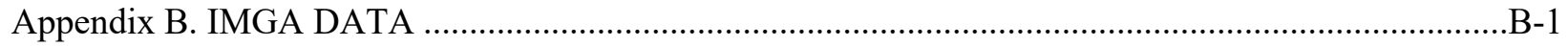

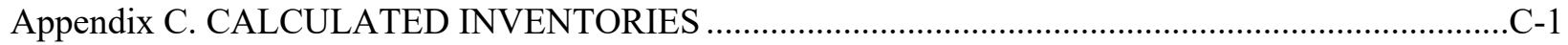


REVISION LOG

\begin{tabular}{cccc}
\hline Revision & Date & Affected pages & Revision description \\
\hline 0 & All & Initial issue & \\
& & \\
& & \\
& & \\
\hline
\end{tabular}




\section{LIST OF FIGURES}

Figure 1-1. X-ray radiographs of $2.5 \mathrm{~mm}$ sections from four AGR-3/4 compacts, with DTF

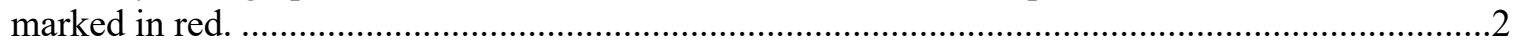

Figure 1-2. Radial deconsolidation rig in raised position for imaging and beaker exchange.......................

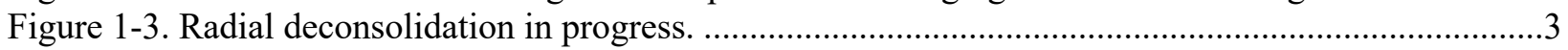

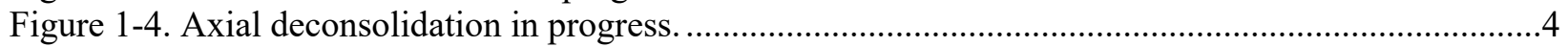

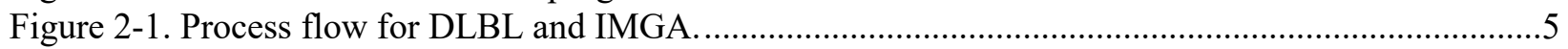

Figure 3-1. Compact 1-4 at each stage of radial deconsolidation. .........................................................9

Figure 3-2. Examples of Compact 1-4 automated photo analysis at each stage of radial

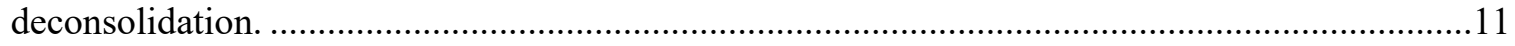

Figure 3-3. Examples of Compact 1-4 automated video analysis at each stage of radial

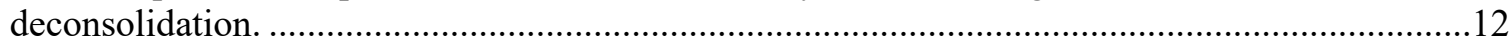

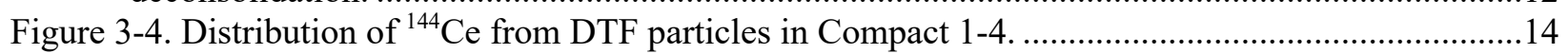

Figure 3-5. Concentration gradient of ${ }^{144} \mathrm{Ce}$ from DTF particles in Compact 1-4...................................15

Figure 3-6. Comparison of ${ }^{144} \mathrm{Ce},{ }^{137} \mathrm{Cs}$, and ${ }^{154} \mathrm{Eu}$ diffusion from DTF particles in Compact 1-4. ............15

Figure 3-7. Comparison of ${ }^{144} \mathrm{Ce},{ }^{235} \mathrm{U}$, and ${ }^{239} \mathrm{Pu}$ diffusion from DTF particles in Compact $1-4 \ldots \ldots \ldots \ldots \ldots . .15$

Figure 3-8. X-ray radiograph of AGR-3/4 compact. ..........................................................................16

Figure 3-9. Measured vs. calculated ${ }^{137} \mathrm{Cs}$ activity in 1344 particles from AGR-3/4 Compact 1-4 ...........17

Figure 4-1. Compact 10-4 at each stage of radial deconsolidation........................................................19

Figure 4-2. Examples of Compact 10-4 automated photo analysis at each stage of radial deconsolidation.

Figure 4-3. Examples of Compact 10-4 automated video analysis at each stage of radial

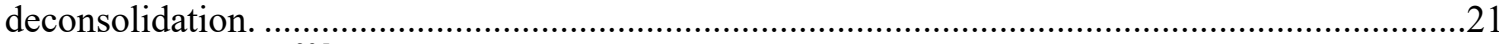

Figure 4-4. Distribution of ${ }^{235} \mathrm{U}$ from DTF particles in Compact 10-4 .............................................22

Figure 4-5. Concentration gradient of ${ }^{235} \mathrm{U}$ from DTF particles in Compact 10-4 .................................23

Figure 4-6. Comparison of ${ }^{144} \mathrm{Ce},{ }^{235} \mathrm{U}$, and ${ }^{239} \mathrm{Pu}$ diffusion from DTF particles in Compact $10-4 \ldots \ldots \ldots \ldots . .23$

Figure 4-7. Comparison of ${ }^{144} \mathrm{Ce},{ }^{137} \mathrm{Cs}$, and ${ }^{154} \mathrm{Eu}$ diffusion from DTF particles in Compact 10-4. ..........24

Figure 4-8. Measured vs. calculated ${ }^{137}$ Cs activity in 1705 particles from AGR-3/4 Compact 10-4.........25 


\section{LIST OF TABLES}

Table 1-1. Irradiation and safety test parameters for AGR-3/4 compacts analyzed in this study................4

Table 3-1. Equal volume segment plan for Compact 1-4 ......................................................................

Table 3-2. Segment results for Compact 1-4 measured with automated photo analysis ..............................8

Table 3-3. Comparison of average calibration factors in pixels $/ \mathrm{mm}$ from Compact 1-4 image analysis....10

Table 3-4. Comparison of analysis results for average initial diameter in $\mathrm{mm}$ for each Compact 1-4

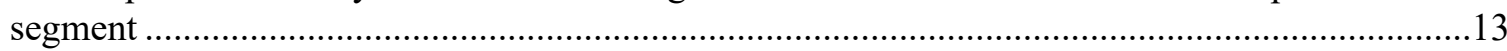

Table 3-5. Particle equivalents of ${ }^{144}$ Ce detected in Compact 1-4 DLBL solutions .................................14

Table 3-6. Number of particles in Compact 1-4 segments .................................................................16

Table 3-7. Statistical summary of Compact 1-4 driver fuel particle activities ..........................................17

Table 4-1. Equal volume segment plan for Compact 10-4 …...............................................................18

Table 4-2. Segment results for Compact 10-4 measured with automated photo analysis ..........................18

Table 4-3. Calibration factors in pixels/mm used for Compact 10-4 image analysis ...............................20

Table 4-4. Comparison of analysis results for initial diameter in mm for each Compact 10-4 segment.....22

Table 4-5. Particle equivalents of ${ }^{235} \mathrm{U}$ detected in Compact 10-4 DLBL solutions..................................22

Table 4-6. Comparison of particle equivalents of select nuclides in Compact 10-4 segments..................24

Table 4-7. Number of particles in Compact 10-4 segments .................................................................24

Table 4-8. Statistical summary of Compact 10-4 driver fuel particle activities .......................................25 


\section{ABBREVIATIONS}

AGR Advanced Gas Reactor (Fuel Development and Qualification Program)

AGR-1 first AGR program irradiation experiment

AGR-2 second AGR program irradiation experiment

AGR-3/4 third and fourth AGR program irradiation experiments

DLBL deconsolidation and leach-burn-leach

DTF designed-to-fail (fuel particle)

EOL end of life

FB-CVD fluidized-bed chemical vapor deposition (coating system)

FIMA fissions per initial metal atom

ID identification

INL Idaho National Laboratory

IMGA Irradiated Microsphere Gamma Analyzer

LBL leach-burn-leach

JMOCUP Jim's MCNP-ORIGEN2 Coupled Utility Program

$\mathrm{M} / \mathrm{A}$

$\mathrm{M} / \mathrm{C}$

measured vs. average

MCNP Monte Carlo N-Particle Transport code

ORIGEN Oak Ridge Isotope Generation and Depletion code

ORNL

PIE

RS

$\mathrm{SD}$

$\mathrm{SiC}$

SP

$\mathrm{TA}_{\max }$

$\mathrm{TA}_{\min }$

TAVA

TRISO

Oak Ridge National Laboratory

post-irradiation examination

randomly-selected (particles)

standard deviation

silicon carbide (TRISO layer)

special particle (abnormal particles typically identified with IMGA)

time-average maximum (temperature)

time-average minimum (temperature)

time-average, volume-average (temperature)

tristructural-isotropic (coated particles)

UCO uranium carbide and uranium oxide (fuel kernels) 


\section{ACKNOWLEDGMENTS}

This work was sponsored by the US Department of Energy Office of Nuclear Energy Advanced Reactor Technologies as part of the Advanced Gas Reactor Fuel Development and Qualification Program. Analysis of leach solutions and Core Conduction Cooldown Test Facility furnace components was conducted by the Oak Ridge National Laboratory (ORNL) Nuclear Analytical Chemistry and Isotopics Laboratory. Hot cell activities were supported by ORNL Irradiated Fuels Examination Laboratory staff. 


\section{INTRODUCTION AND BACKGROUND}

The Advanced Gas Reactor (AGR) Fuel Development and Qualification Program third and fourth irradiation experiments (AGR-3/4), originally planned as separate tests, were combined in one test train for irradiation in the Advanced Test Reactor at Idaho National Laboratory (INL). The irradiation test began on December 14, 2011 and ended on April 12, 2014 (Collin 2016). The originally planned AGR-3 and AGR-4 irradiation experiments were both focused on obtaining data on fission product transport to support the improvement of modeling. The AGR-3 experimental plan was focused on gaseous and metallic fission product release from the kernels and diffusion in the coatings during irradiation and postirradiation safety testing. The AGR-4 experimental plan was focused on diffusivities and sorptivities in the compact matrix and reactor graphite (Petti et al. 2005). These two goals were combined in the AGR-3/4 irradiation, which consisted of twelve independently monitored capsules that each contained four AGR-3/4 compacts in a single stack surrounded by an inner ring of matrix or graphite and an outer ring of graphite. There were two capsule types: a standard capsule and a "fuel body", in which the outer graphite ring included a floor and cap that fully enclosed the fuel (Stempien et al. 2018a). The fuel body design supported post-irradiation safety testing of the intact fuel and ring assembly to provide data on fission product transport and release from matrix and graphite at accident temperatures (Demkowicz 2017).

The key feature of the AGR-3/4 compacts was the inclusion of 20 "designed-to-fail" (DTF) fuel particles distributed along the centerline of each compact. A summary of the AGR-3/4 irradiation test compact fabrication campaign has been published by Hunn et al. (2012). The DTF fuel particles and surrounding "driver fuel" particles were fabricated at Oak Ridge National Laboratory (ORNL) using a lab-scale fluidized-bed chemical vapor deposition (FB-CVD) coating system with a chamber inner diameter of $50 \mathrm{~mm}$. Kernels came from a single composite (G73V-20-69303) manufactured by BWX Technologies, which was upgraded by manual sorting to remove debris and irregularly shaped kernels and renamed LEU03. The kernels contained both uranium carbide and uranium oxide phases (UCO) with an enrichment of $19.7 \%$, and were similar to those used in the first AGR program irradiation experiment (AGR-1). Kernel diameter was nominally $350 \mu \mathrm{m}$, with a measured average value of $357.3 \mu \mathrm{m}$ and a standard deviation of $1.6 \mu \mathrm{m}$ (Kercher and Hunn 2006). The AGR-3/4 driver fuel particles were standard tristructural-isotropic (TRISO)-coated particles similar to the TRISO particles used in the AGR-1 experiment (Lowden 2006). Four coater batches were upgraded and combined into one composite (LEU03-09T). The TRISO particle batches and composite were thoroughly characterized and found to pass all specifications (Hunn and Lowden 2007). The DTF particles were produced in a single batch (LEU03-07DTF) after an extensive development effort to ensure that the $20 \mu \mathrm{m}$ pyrolytic carbon coating met the specified properties for a coating expected to fail during irradiation without failing prematurely during compact heat treatment up to $1,800^{\circ} \mathrm{C}$ (Kercher et al. 2011). Overcoating and pressing of the AGR-3/4 DTF and driver fuel particles into the final cylindrical compact fuel form (nominally one half of an inch in both diameter and length) was accomplished using similar methods developed for the fabrication of compacts made for the second AGR program irradiation experiment (AGR-2), with the exception of new techniques for overcoating and distributing the DTF particles along the center line of the AGR-3/4 fuel compact. Overcoated DTF particles were imaged with x-ray radiography to verify that each overcoated particle contained exactly one DTF particle, and the overcoated particles were hand counted to ensure that each compact held exactly twenty DTF particles. Radiographs of $2.5 \mathrm{~mm}$ sections cut from the center of four AGR-3/4 compacts are shown in Figure 1-1, in which the compacts were sectioned so the radiography would show the DTF particles. The DTF particles were evenly distributed in the bottom three-quarters of the compact and within $\sim 1.3 \mathrm{~mm}$ of the compact centerline. The partial collapse of the linear stack of overcoated DTF particles was likely due to the overcoated DTF and surrounding driver fuel particles redistributing slightly after removal of the tube used to hold the overcoated DTF in position during addition of the overcoated driver fuel particles. Thorough characterization of AGR-3/4 fuel compact composite determined that it conformed to all specifications (Hunn, Trammell, and Montgomery 2011). In addition to 20 DTF particles, each AGR-3/4 compact held an average of 1898 driver fuel particles, based on a count of the particles deconsolidated from 18 randomly-selected compacts. 

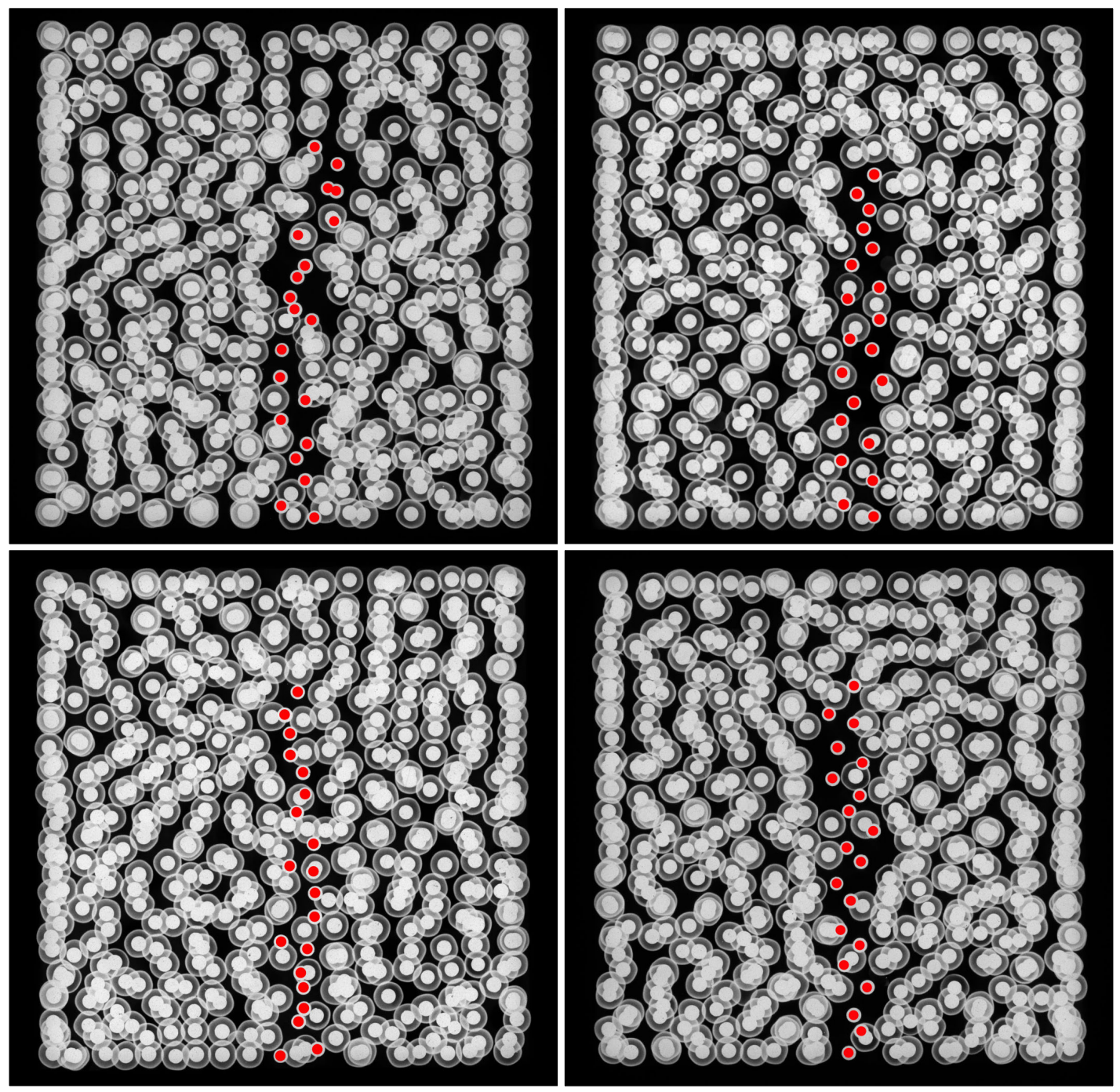

Figure 1-1. X-ray radiographs of $2.5 \mathrm{~mm}$ sections from four AGR-3/4 compacts, with DTF marked in red.

Ongoing post-irradiation examination (PIE) of the AGR-3/4 compacts includes radial deconsolidation of individual compacts to segment the compacts into separate collections of particles and matrix debris from concentric cylindrical volumes, each of which can be subjected to leach-burn-leach (LBL) analysis to quantify the presence of actinides and fission products released by the driver fuel and DTF particles. Typically, three cylindrical rings of driver fuel particles and matrix are removed, leaving a cylindrical core encompassing the DTF particles. The core section is then axially deconsolidated. Initial development and testing of the radial deconsolidation process were accomplished using unirradiated AGR-3/4 compacts (Helmreich, Montgomery, and Hunn 2015), and then the concept was modified for deconsolidation of irradiated AGR-3/4 compacts in the INL hot cells (Stempien 2017). Detailed information on the process and equipment can be obtained from the referenced reports.

Radial deconsolidation of irradiated AGR-3/4 compacts began at ORNL in 2020. Excess equipment from the development of the INL hot cell rig was shipped to ORNL and assembled for use at ORNL with minor modifications (Figure 1-2-Figure 1-4). Notably, a 20 mil shim $(0.5 \mathrm{~mm})$ was inserted between the sample holder and drive support bracket to reduce wobble of the compact and rod during rotation, and a slot was cut in the beaker opposite the spout so the required level of the nitric acid was lower, which made it easier to pick up the beaker without spilling acid. Deconsolidation was performed using $6 \mathrm{~mol} / \mathrm{L}$ nitric acid, and current was controlled at $0.8 \mathrm{~A}$ for the radial deconsolidation or $0.35 \mathrm{~A}$ for the axial deconsolidation (direct current voltage was typically around $5 \mathrm{~V}$ ). 


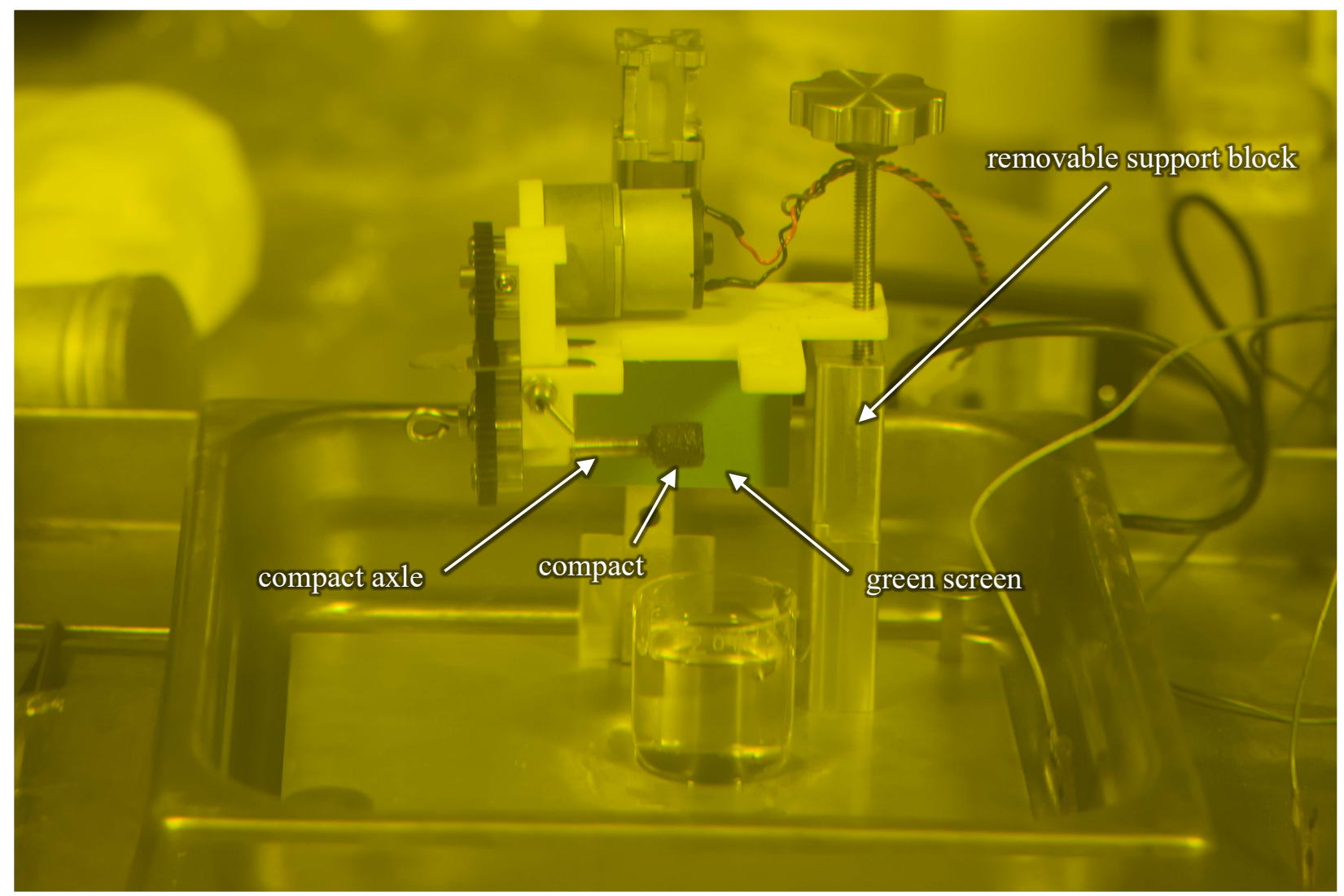

Figure 1-2. Radial deconsolidation rig in raised position for imaging and beaker exchange.

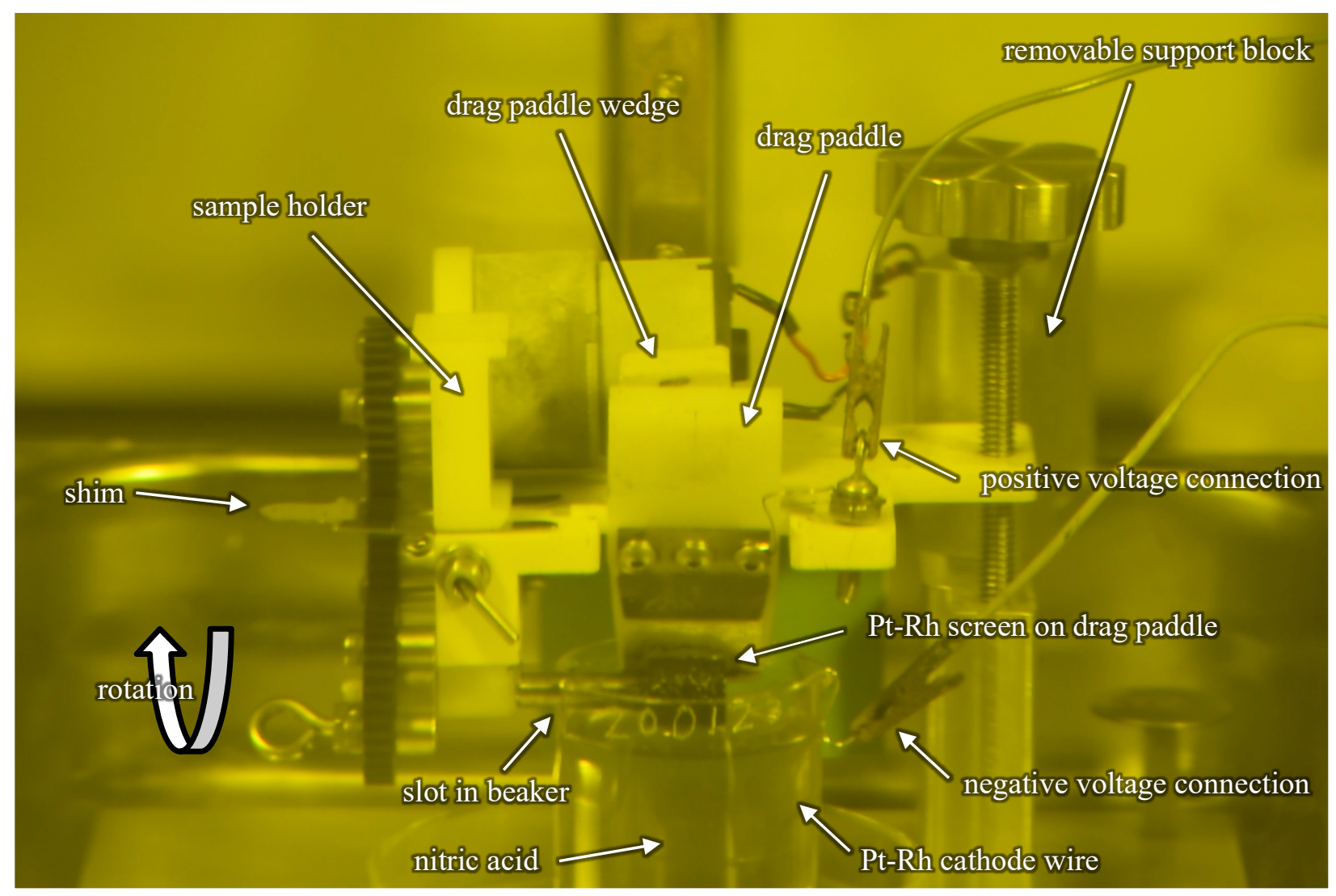

Figure 1-3. Radial deconsolidation in progress. 


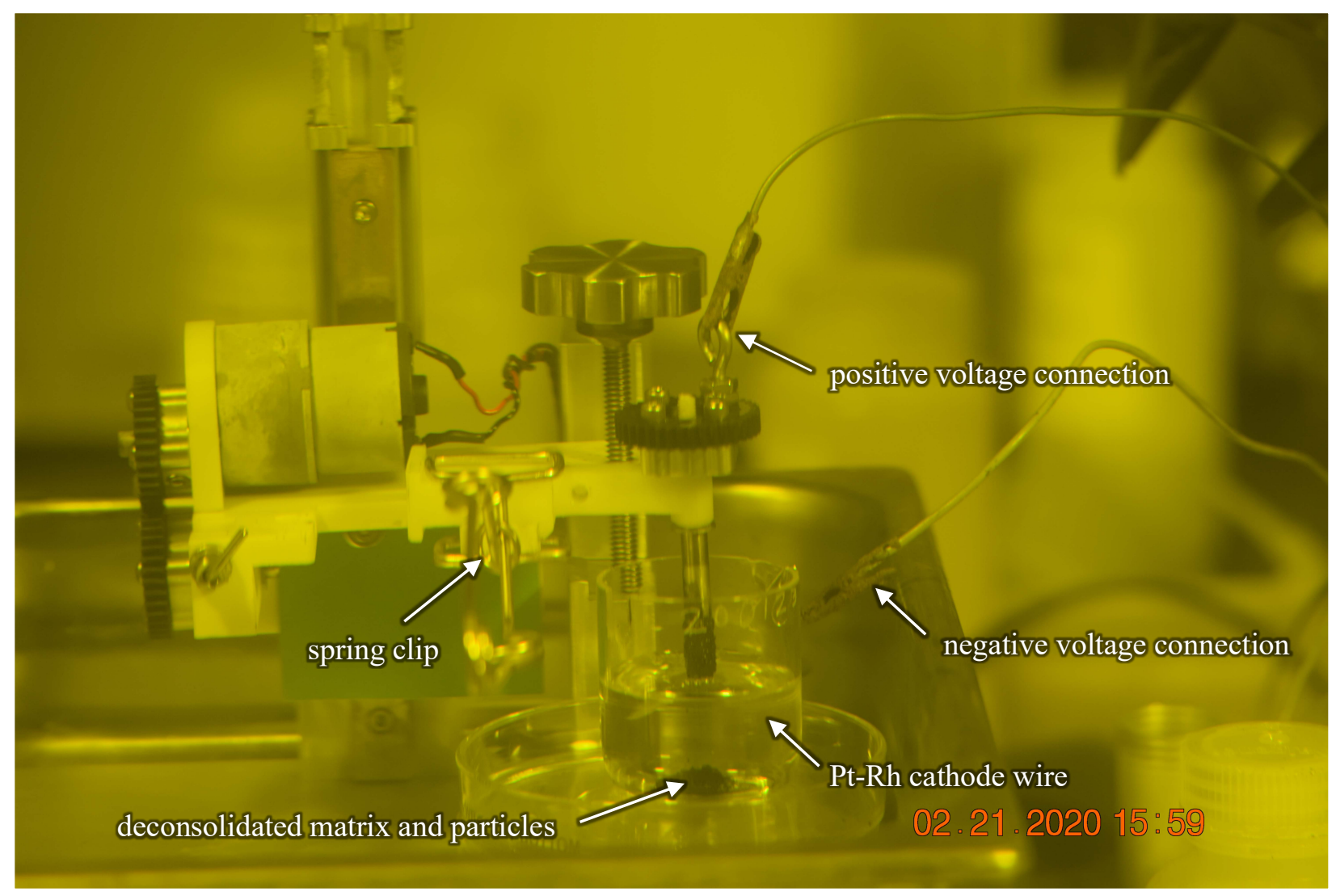

Figure 1-4. Axial deconsolidation in progress.

The AGR-3/4 compacts were irradiated to average calculated burnups of 4.85-15.27\% fissions per initial metal atom (FIMA), and the average calculated fluences of fast neutrons with energies $E_{n}>0.18 \mathrm{MeV}$ were $1.19-5.32 \times 10^{25} \mathrm{n} / \mathrm{m}^{2}$ (Sterbentz 2015). The calculated time-average, volume-average (TAVA) compact temperatures ranged between $832-1,376^{\circ} \mathrm{C}$ (Hawkes 2014). Table 1-1 shows the calculated irradiation conditions for two compacts subjected to radial deconsolidation and LBL (DLBL) at ORNL. Both compacts were irradiated in standard (not fuel body) capsules. Compact 1-4 was from the capsule located at the bottom of the test train and experienced burnup and temperatures near the lower end of the ranges for compacts in the AGR-3/4 irradiation test. Compact 10-4 experienced irradiation burnup and temperatures near the middle of the ranges and was safety tested prior to DLBL (Stempien et al. 2018b).

Table 1-1. Irradiation and safety test parameters for AGR-3/4 compacts analyzed in this study

\begin{tabular}{|c|c|c|c|c|c|c|c|}
\hline \multirow{2}{*}{ Compact ID $^{a}$} & \multirow{2}{*}{$\begin{array}{l}\text { Fabrication } \\
\text { ID number }\end{array}$} & \multirow{2}{*}{$\begin{array}{l}\text { Safety test } \\
\left({ }^{\circ} \mathrm{C}\right)\end{array}$} & \multirow{2}{*}{$\begin{array}{l}\text { Burnup }^{c} \\
\text { (\% FIMA) }\end{array}$} & \multirow{2}{*}{$\begin{array}{l}\text { Fast fluence }{ }^{c} \\
\qquad\left(\mathbf{n} / \mathbf{m}^{2}\right)\end{array}$} & \multicolumn{3}{|c|}{ Temperature $^{d}\left({ }^{\circ} \mathrm{C}\right)$} \\
\hline & & & & & TAVA & $\mathbf{T A}_{\min }$ & TA $A_{\max }$ \\
\hline AGR-3/4 Compact 1-4 & Z012 & none & 6.85 & $2.10 \times 10^{25}$ & 929 & 866 & 972 \\
\hline AGR-3/4 Compact 10-4 & Z140 & 1,400 & 11.43 & $3.75 \times 10^{25}$ & 1,168 & 1,079 & 1,231 \\
\hline
\end{tabular}

\footnotetext{
${ }^{a}$ The compact identification (ID) denotes the compact's location in the irradiation test train: capsule-level (Collin 2015).

${ }^{b}$ Each compact in the fabrication lot (LEU03-10T-OP2/LEU03-07DTF-OP1)-Z had a unique compact ID number from 001-175, and physical properties data are available and referenced by compact ID number (Hunn, Trammell, and Montgomery, 2011).

${ }^{c}$ Compact average burnups and fast neutron fluences $\left(\mathrm{E}_{\mathrm{n}}>0.18 \mathrm{MeV}\right)$ are based on daily depletion calculations (Sterbentz 2015).

${ }^{d}$ Compact TAVA, time-average minimum $\left(\mathrm{TA}_{\min }\right)$ and time-average maximum $\left(\mathrm{TA}_{\max }\right)$ temperatures are based on thermal calculations (Hawkes 2016).
} 


\section{LBL AND IMGA METHODS*}

After radial deconsolidation, LBL and gamma scanning of individual particles were performed using the same methods that were developed for destructive PIE of as-irradiated AGR-1 compacts, and the details of the equipment and methods have been previously reported (Hunn et al. 2013). Figure 2-1 is a flow diagram of the typical process for compact DLBL integrated with gamma survey of the particle inventory using the ORNL Irradiated Microsphere Gamma Analyzer (IMGA). Deconsolidation and leach solutions were analyzed by gamma and mass spectrometry, providing information about actinides and fission products that were not sealed inside retentive $\mathrm{SiC}$ layers. Results are expected to be dominated by actinides and fission products from the twenty DTF particles in each AGR-3/4 compact. However, actinides and fission products leached in the deconsolidation acid, pre-burn Soxhlet extractions of the particles and matrix, pot boil of the particles and matrix, and postburn pot leaches of the matrix may have also come from (1) uranium outside the $\mathrm{SiC}$ in the as-fabricated compacts, (2) diffusion through the driver fuel $\mathrm{SiC}$ layers during irradiation or safety testing, and/or (3) exposed kernels in driver fuel particles with failed TRISO. In addition, actinides and fission products leached in the postburn Soxhlet extractions of the particles may have come from (1) exposed kernels in driver fuel particles with failed $\mathrm{SiC}$ and/or (2) diffusively-released actinides and fission products that were not leached prior to the burn because they were previously sequestered in a pyrolytic carbon layer or in an insoluble chemical form.

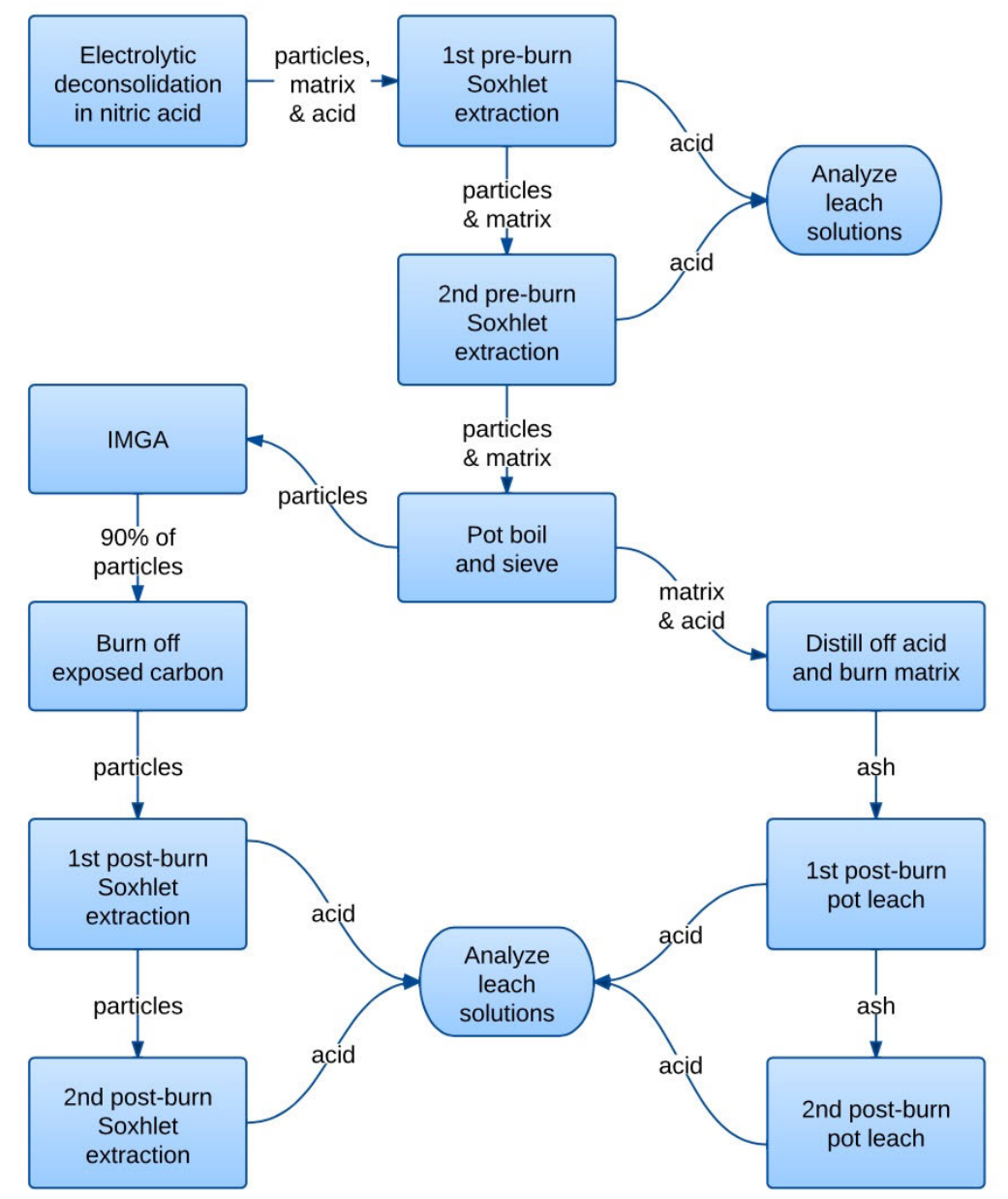

Figure 2-1. Process flow for DLBL and IMGA.

\footnotetext{
* This experimental methods section is a revised version of a similar section in a previous AGR-2 PIE report (Hunn et al. 2020), and is included herein for contextual information and definition of common terminology used throughout this report.
} 
Actinide and fission product measurements were converted to fractions of the total compact inventory, or compact fraction, using the standard ORNL AGR PIE approach (Hunn et al. 2013), which involved dividing by the calculated inventory. The calculated total inventory of each nuclide was estimated using physics calculations (Sterbentz 2015) and reported at three specific times after the end of the irradiation, also called the end of life (EOL): namely, one day after EOL, one year after EOL, and two years after EOL. Radionuclide quantities measured by gamma spectrometry (e.g., ${ }^{106} \mathrm{Ru},{ }^{110 \mathrm{~m}} \mathrm{Ag},{ }^{125} \mathrm{Sb},{ }^{134} \mathrm{Cs},{ }^{137} \mathrm{Cs}$, ${ }^{144} \mathrm{Ce}$, ${ }^{154} \mathrm{Eu}$, and ${ }^{155} \mathrm{Eu}$ ), or chemical separation and beta spectrometry in the special case of ${ }^{90} \mathrm{Sr}$, were decay-corrected to one day after EOL and divided by the calculated total inventory at that time to determine the compact fraction. For stable nuclides and actinides (e.g. ${ }^{235} \mathrm{U},{ }^{236} \mathrm{U},{ }^{238} \mathrm{U},{ }^{239} \mathrm{Pu}$, and ${ }^{240} \mathrm{Pu}$ ), the measured quantity was divided by the calculated total inventory at one year after EOL. This was done because radionuclide decay generated additional actinide and stable nuclides over the first year after the compacts were removed from the reactor, while any further increase in the calculated total inventories after one year was typically negligible. The mass spectrometry analysis was almost always performed after one year based on the time required for the test train to cool down and be disassembled. Results were also calculated and are often presented in terms of the equivalent particle inventory, or the number of particle equivalents, which is defined as the compact fraction multiplied by the average number of particles per compact: 1,918 for AGR-3/4 compacts (Hunn, Trammell, and Montgomery 2011).

The IMGA data are reported herein as activities in Bq/particle that were decay-corrected to one day after EOL or various unitless ratios that communicate the retained fraction of each nuclide. The simplest ratio was the measured activity of a particle, $A_{i}$, normalized to the average measured activity for all particles in a sample of $n$ particles, reported herein as the measured vs. average (M/A) value. For example,

$$
\frac{\mathrm{A}_{\mathrm{i}}\left({ }^{144} \mathrm{Ce}\right)}{\sum_{\mathrm{i}=1}^{\mathrm{n}}\left(\frac{1}{\mathrm{n}}\right) \mathrm{A}_{\mathrm{i}}\left({ }^{144} \mathrm{Ce}\right)}
$$

is the ${ }^{144} \mathrm{Ce} \mathrm{M} / \mathrm{A}$ value for Particle $i$ (i.e., the measured ${ }^{144} \mathrm{Ce}$ activity of Particle $i$, normalized to the average ${ }^{144} \mathrm{Ce}$ activity). The ratio form in Equation 2.1 was used to generate ${ }^{137} \mathrm{Cs},{ }^{144} \mathrm{Ce}$, and ${ }^{106} \mathrm{Ru}$ histograms of the IMGA survey results, which were centered on unity and had a distribution that resulted from measurement uncertainty and real particle-to-particle variation in isotopic content. For particles with negligible radionuclide release, this real particle-to-particle variation was related to variation in fissionable material and burnup, which might occur due to variation in kernel size and local neutron fluence.

A calculated value for the expected activity of a given radionuclide in each particle was estimated from the average calculated activity for that nuclide, $A_{\text {calc }}$, predicted by physics simulations (Sterbentz 2015) multiplied by the normalized activity of a different and preferably well-retained radionuclide to adjust for particle-to-particle variation in fissionable material and burnup. For instance,

$$
\mathrm{A}_{\text {calc }}\left({ }^{137} \mathrm{Cs}\right) \frac{\mathrm{A}_{\mathrm{i}}\left({ }^{144} \mathrm{Ce}\right)}{\sum_{\mathrm{i}=1}^{\mathrm{n}}\left(\frac{1}{\mathrm{n}}\right) \mathrm{A}_{\mathrm{i}}\left({ }^{144} \mathrm{Ce}\right)}
$$

is the calculated ${ }^{137} \mathrm{Cs}$ activity of Particle $i$ after adjusting for particle-to-particle variation in fissionable material and burnup using the normalized ${ }^{144} \mathrm{Ce}$ activity of Particle $i$. The normalized ${ }^{144} \mathrm{Ce}$ activity was typically used for making the adjustment to the average calculated ${ }^{137} \mathrm{Cs}$ activity to account for the variation in fissionable material and burnup in each particle. However, the normalized ${ }^{106} \mathrm{Ru}$ activity was used if it could be measured with greater accuracy, which was the case for later PIE due to quicker decay of the ${ }^{144} \mathrm{Ce}$ activity and the lower energy of the ${ }^{144} \mathrm{Ce}$ gamma emission.

The ratio of the measured activity in Particle $i$ vs. the calculated activity of Particle $i$ is reported herein as the measured vs. calculated $(\mathrm{M} / \mathrm{C})$ value. For example, 


$$
\frac{\mathrm{A}_{\mathrm{i}}\left({ }^{137} \mathrm{Cs}\right)}{\mathrm{A}_{\text {calc }}\left({ }^{137} \mathrm{Cs}\right) \frac{\mathrm{A}_{\mathrm{i}}\left({ }^{144} \mathrm{Ce}\right)}{\sum_{\mathrm{i}=1}^{\mathrm{n}}\left(\frac{1}{\mathrm{n}}\right) \mathrm{A}_{\mathrm{i}}\left({ }^{144} \mathrm{Ce}\right)}}
$$

is the ${ }^{137} \mathrm{Cs} \mathrm{M} / \mathrm{C}$ value for Particle $i$ adjusted for particle-to-particle variation in fissionable material and burnup using the normalized ${ }^{144} \mathrm{Ce}$ activity of Particle $i$. The ratio form in Equation 2.3 was used to generate a ${ }^{137} \mathrm{Cs} \mathrm{M} / \mathrm{C}$ histogram from the IMGA survey data that illustrated the cesium retention in each particle, in which particles with low cesium retention could be identified as discrete values below the main distribution. These low cesium particles were sorted out during the IMGA survey and labeled as special particles (SP) using the compact number, segment number, and a sequential ID (e.g., Particle 104-S1-SP01, Particle 104-S1-SP02, etc.). Special particles were retained for possible future examination.

After IMGA survey, special particles and a randomly riffled subsample of about 45 randomly-selected (RS) particles were subjected to longer gamma counting to obtain the better counting statistics. The M/C values were calculated from the long-count IMGA data for radionuclides other than ${ }^{137} \mathrm{Cs}$ using the ratio form in Equation 2.3, but rather than ${ }^{144} \mathrm{Ce}$, the normalized ${ }^{137} \mathrm{Cs}$ activity was used for making the adjustment to the average calculated radionuclide activities. For example,

$$
\frac{\mathrm{A}_{\mathrm{i}}\left({ }^{154} \mathrm{Eu}\right)}{\mathrm{A}_{\text {calc }}\left({ }^{154} \mathrm{Eu}\right) \frac{\mathrm{A}_{\mathrm{i}}\left({ }^{137} \mathrm{Cs}\right)}{\sum_{\mathrm{i}=1}^{\mathrm{n}}\left(\frac{1}{n}\right) \mathrm{A}_{\mathrm{i}}\left({ }^{137} \mathrm{Cs}\right)}}
$$

is the ${ }^{154} \mathrm{Eu} \mathrm{M} / \mathrm{C}$ value for Particle $i$ adjusted for particle-to-particle variation in fissionable material and burnup using the normalized ${ }^{137} \mathrm{Cs}$ activity of Particle $i$. The ${ }^{137} \mathrm{Cs}$ radionuclide was chosen for the adjustment over ${ }^{144} \mathrm{Ce}$ based on comparisons that showed that ${ }^{137} \mathrm{Cs}$ was a better choice for the inventory adjustment (Hunn et al. 2012). In the absence of $\mathrm{SiC}$ failure, cesium was retained well by the $\mathrm{SiC}$ coating, sometimes better than cerium. Furthermore, the buildup of ${ }^{137} \mathrm{Cs}$ was much more linear than ${ }^{144} \mathrm{Ce}$ as a function of burnup throughout the course of the AGR program irradiations because the irradiation tests extended over several ${ }^{144} \mathrm{Ce}$ half-lives. The average $\mathrm{M} / \mathrm{C}$ for well-retained radionuclides was not always close to unity, because error in the calculated inventory sometimes resulted in an offset which could be significant. The offset was substantial for the radionuclides of europium and antimony as a result of large errors in the calculated values.

Another calculated ratio, reported herein as the measured vs. adjusted average (M/AA) value, was determined in a manner similar to that used to determine $\mathrm{M} / \mathrm{C}$, except the offset in the calculated activity was mostly removed by replacing the average calculated activity, $A_{\text {calc }}$, predicted by physics simulations and used in Equation 2.3 and Equation 2.4 with the average measured activity. For instance,

$$
\frac{\mathrm{A}_{\mathrm{i}}\left({ }^{154} \mathrm{Eu}\right)}{\sum_{\mathrm{i}=1}^{\mathrm{n}}\left(\frac{1}{\mathrm{n}}\right) \mathrm{A}_{\mathrm{i}}\left({ }^{154} \mathrm{Eu}\right) \frac{\mathrm{A}_{\mathrm{i}}\left({ }^{137} \mathrm{Cs}\right)}{\sum_{\mathrm{i}=1}^{\mathrm{n}}\left(\frac{1}{n}\right) \mathrm{A}_{\mathrm{i}}\left({ }^{137} \mathrm{Cs}\right)}}
$$

is the ${ }^{154} \mathrm{Eu} \mathrm{M} / \mathrm{AA}$ value for Particle $i$ adjusted for particle-to-particle variation in fissionable material and burnup using the normalized ${ }^{137} \mathrm{Cs}$ activity of Particle $i$. This ratio form is useful for identifying particles with average retention. 


\section{AGR-3/4 COMPACT 1-4}

\subsection{RADIAL DECONSOLIDATION AND DIMENSIONAL ANALYSIS OF COMPACT 1-4}

Compact 1-4 was radially deconsolidated (Figure 1-3) in three stages to remove three cylindrical rings of driver fuel particles and matrix, leaving a cylindrical core encompassing the DTF particles. The core was then axially deconsolidated (Figure 1-4). A segment plan to achieve four segments of equal volume is shown in Table 3-1. Radial deconsolidation was paused several times during each deconsolidation stage to obtain a photo, which was manually examined to evaluate progress toward the target diameter for the segment (Table 3-1). Because of concern with overshooting the target diameters for each segment, deconsolidation was stopped short of each. At the end of each radial deconsolidation, the compact was raised to the imaging position (Figure 1-2), loose debris on the screen and compact were gently rinsed off into the deconsolidation beaker, the drag paddle was removed, and images were acquired of the compact to measure the residual diameter. At least 50 photos and a $30 \mathrm{~s}$ video were acquired of the rotating compact. The number of photos was based on analysis of the distribution of rotations presented to the camera, in which 40-50 images acquired at a varying capture rate was determined to provide sufficient randomness in the compact orientation. Table 3-2 shows the actual segment dimensions and volumes as determined by automated image analysis of the photos (discussed below); the time that deconsolidation was active (power applied) for each radially deconsolidated segment is also shown.

Table 3-1. Equal volume segment plan for Compact 1-4

\begin{tabular}{lcccc}
\hline Quantity & Segment 1 & Segment 2 & Segment 3 & Segment 4 \\
\hline Initial diameter $(\mathrm{mm})$ & 12.23 & 10.59 & 8.65 & 6.11 \\
Target diameter $(\mathrm{mm})$ & 10.59 & 8.65 & 6.11 & 0 \\
Segment thickness $(\mathrm{mm})$ & 0.82 & 0.97 & 1.27 & solid \\
Segment volume $\left(\mathrm{cm}^{3}\right)$ & 0.366 & 0.366 & 0.366 & 0.366
\end{tabular}

Note: Average diameter of the irradiated compact was $12.227 \mathrm{~mm}$ with a standard deviation of

$0.012 \mathrm{~mm}$, and length from a single measurement was $12.459 \mathrm{~mm}$ (Stempien et al. 2016).

Table 3-2. Segment results for Compact 1-4 measured with automated photo analysis

\begin{tabular}{lcccc}
\hline Quantity & Segment 1 & Segment 2 & Segment 3 & Segment 4 \\
\hline Initial diameter $(\mathrm{mm})$ & 12.23 & 11.02 & 9.28 & 6.55 \\
Residual diameter $(\mathrm{mm})$ & 11.02 & 9.28 & 6.55 & 0 \\
Segment thickness $(\mathrm{mm})$ & 0.60 & 0.87 & 1.37 & solid \\
Segment volume $\left(\mathrm{cm}^{3}\right)$ & 0.274 & 0.346 & 0.423 & 0.420 \\
Deconsolidation time $(\mathrm{min})$ & 42 & 43 & 66 & - \\
\hline
\end{tabular}

Photos of the compact at each stage in the process are shown in Figure 3-1. Material removal was relatively uniform along the length and around the circumference of the compact with respect to the average driver fuel particles diameter of $0.819 \mathrm{~mm}$ (Hunn and Lowden 2007). The key to this uniform removal was the use of the Pt-Rh screen, which not only provided electrical contact for the electrolytic circuit, but also provided a gentle shear force that helped dislodge particles and matrix debris as the matrix graphite was intercalated by the nitrate anions (Helmreich, Montgomery, and Hunn 2015). The residual diameter of the compact after the radial deconsolidation of Segment 3 was close to the outer diameter of the stainless steel tube used as a drive axle for compact rotation. The axle diameter of $6 \mathrm{~mm}$ presented a practical limit to the outer diameter of the solid core segment. This diameter was more than sufficient to ensure that any residuals of the DTF particles that remained in their original location $(<1.5 \mathrm{~mm}$ from the compact axis) were located within the core (Figure 1-1). 


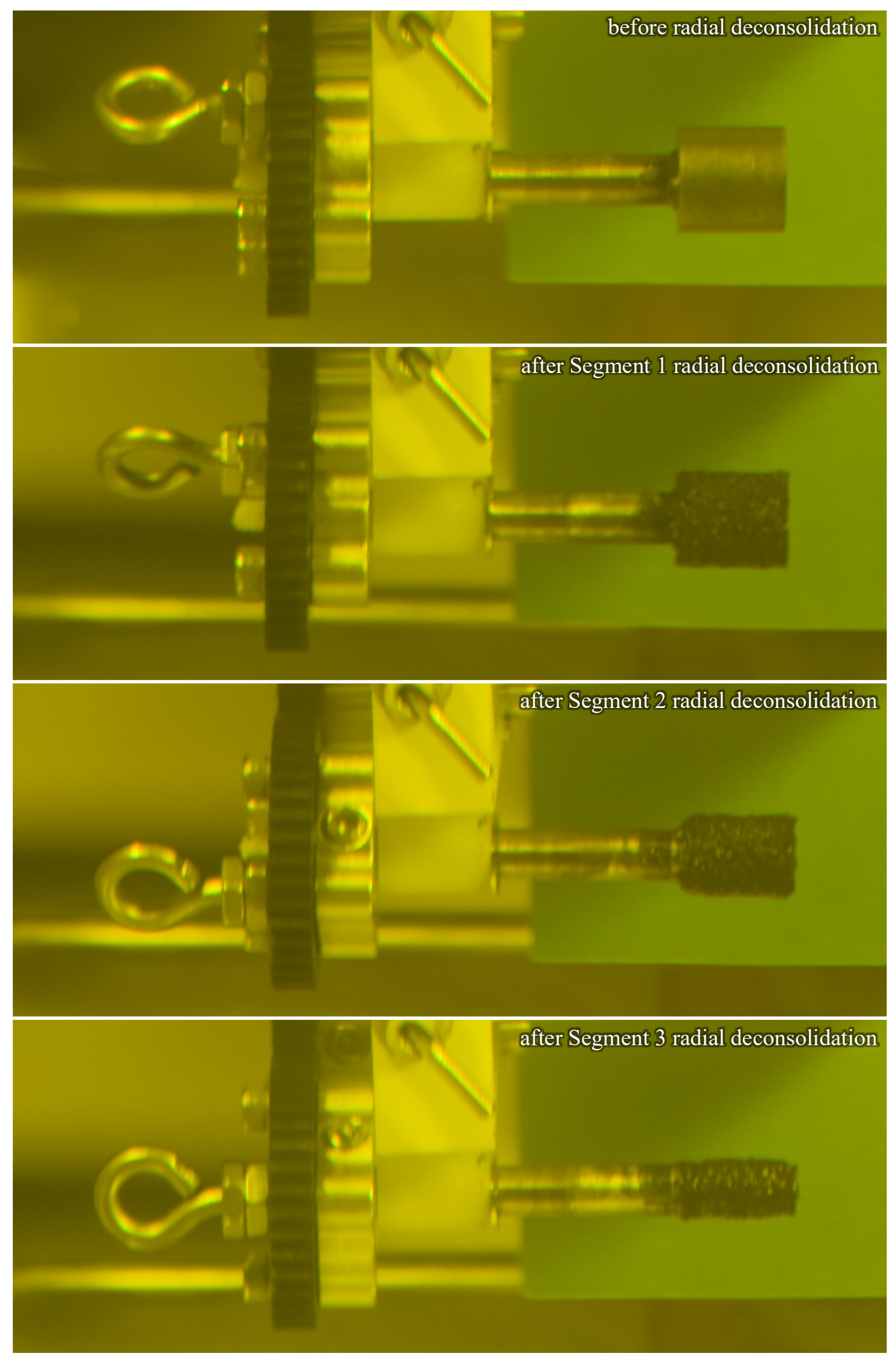

Figure 3-1. Compact 1-4 at each stage of radial deconsolidation. 
Automated image analysis was accomplished using a custom MATLAB script designed to differentiate the boundary between the image of the compact and the green cardboard located behind the compact. The green cardboard provided a convenient monochromatic "green screen" background that could be digitally removed; however, insufficient lighting in the hot cell produced shadows that introduced some challenges to this aspect of the image analysis. The MATLAB script also included code for the determination of the axle boundary, which could be used in two ways. The axle boundary could be used to apply a rotational correction to the image if the axle edges were not aligned to the image pixel array, which would effectively square the compact edges to the image as well. This rotational correction could be applied to each image individually to account for wobble or precession of the rotating axle. As a result of careful camera alignment and the insertion of a shim to remove wobble, no significant angle between the axle and the horizontal image axis was observed in any of the photos or videos, so no image rotation was applied.

The axle boundary could also be used to dimensionally calibrate the image based on its known diameter. However, the accuracy and precision of this calibration method was poor, due to low resolution and nonoptimal contrast at the axle boundary, coupled with the relatively small diameter of the axle rod, in which the uncertainty in determining the approximately 125 pixel axle diameter was in most cases greater than \pm 6 pixels $( \pm 5 \%)$. In lieu of calibrating each image using the axle diameter, the average diameter of the asirradiated compact of $12.227 \mathrm{~mm}$, which was measured with a micrometer during early AGR-3/4 PIE (Stempien et al. 2016), was used to determine one calibration factor for all photos and one calibration factor for all videos. This approach was supported by (1) the more effective boundary recognition achievable for the compact vs. the axle, (2) the larger compact size, which reduced the impact of low image resolution, and (3) a consistent image magnification within each image set and between photo or video image sets taken at different stages of the radial deconsolidation. Consistent magnification was achieved by establishing a reproducible camera placement, and this was verified by measuring the pixel height of the removable support block shown in Figure 1-2, which varied less than $0.1 \%$ between all photo image sets (1003-1004 pixels). Replacing the independent calibration of each image based on the axle boundary identification with the average image calibration based on $\sim 50$ images of the rotating compact prior to the start of the radial deconsolidation reduced the percent standard deviation in the measured as-irradiated compact diameter from $0.9 \%$ to $0.1 \%$ for the automated photo analysis and from $1.8 \%$ to $0.3 \%$ for the automated video analysis. The difference in the stochastic variation of the photo analysis vs. the video analysis was directly related to the pixel density of the acquired images, which was $32 \%$ lower for the video acquisition. Table 3-3 shows the average and standard deviation of the unused calibration factors obtained from the individual axle measurements compared with the single calibration factors that were ultimately applied.

Table 3-3. Comparison of average calibration factors in pixels $/ \mathrm{mm}$ from Compact 1-4 image analysis

\begin{tabular}{llcccc}
\hline $\begin{array}{l}\text { Calibration } \\
\text { Source }\end{array}$ & Analysis Method & $\begin{array}{c}\text { Before } \\
\text { Segment 1 }\end{array}$ & $\begin{array}{c}\text { After } \\
\text { Segment 1 }\end{array}$ & $\begin{array}{c}\text { After } \\
\text { Segment 2 }\end{array}$ & $\begin{array}{c}\text { After } \\
\text { Segment 3 }\end{array}$ \\
\hline Whole compact & automated from photos & $20.660 \pm 0.034$ & $20.660 \pm 0.034$ & $20.660 \pm 0.034$ & $20.660 \pm 0.034$ \\
Axle & automated from photos & $20.852 \pm 0.178$ & $21.905 \pm 0.260$ & $22.633 \pm 0.557$ & $21.936 \pm 0.501$ \\
Whole compact & automated from video & $6.730 \pm 0.022$ & $6.730 \pm 0.022$ & $6.730 \pm 0.022$ & $6.730 \pm 0.022$ \\
Axle & automated from video & $7.042 \pm 0.121$ & $7.129 \pm 0.174$ & $7.195 \pm 0.255$ & $7.28 \pm 0.289$ \\
\hline
\end{tabular}

Note: Shaded values obtained from the as-irradiated compact prior to radial deconsolidation were applied for image analysis. Note: Plus/minus values are the standard deviation of the measurements of each calibration factor.

Figure 3-2 shows an example of the output images from the automated photo analyses for each stage of radial deconsolidation, and Figure 3-3 shows examples of the automated video analyses. The blue overlay shows what the image analysis identified as part of the compact. The left edge of the blue field is truncated based on a user defined search area. The red lines show where the image analysis marked the axle boundaries and centerline. Figure 3-2c and Figure 3-2d are clear examples where the image analysis failed to accurately identify the top of the axle. Figure $3-3 \mathrm{c}$ is an example unique to the video analysis where there was an obvious excursion in the compact area; these cases were manually discarded after inspecting each output image from the automated analyses. 

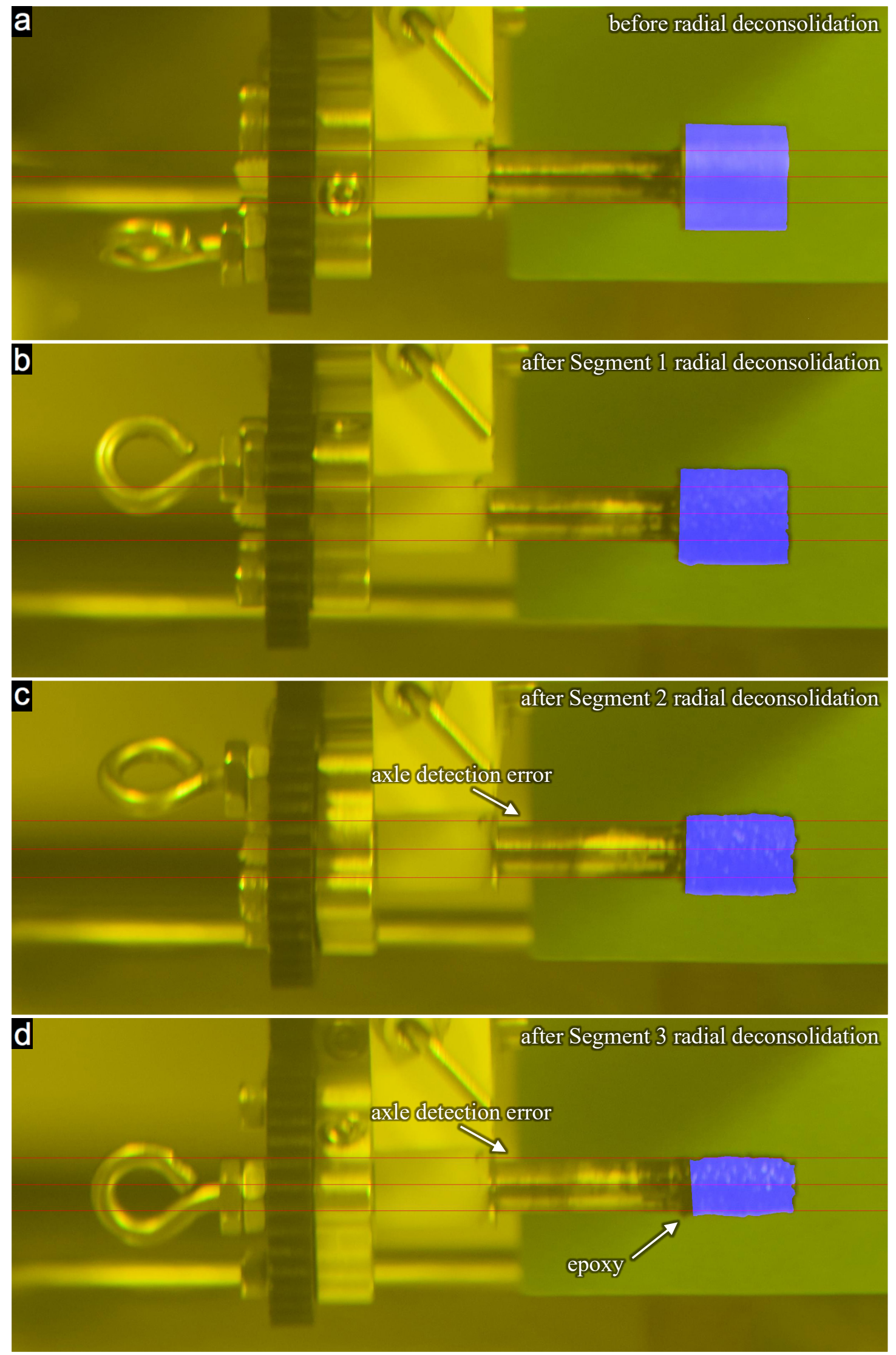

Figure 3-2. Examples of Compact 1-4 automated photo analysis at each stage of radial deconsolidation. 

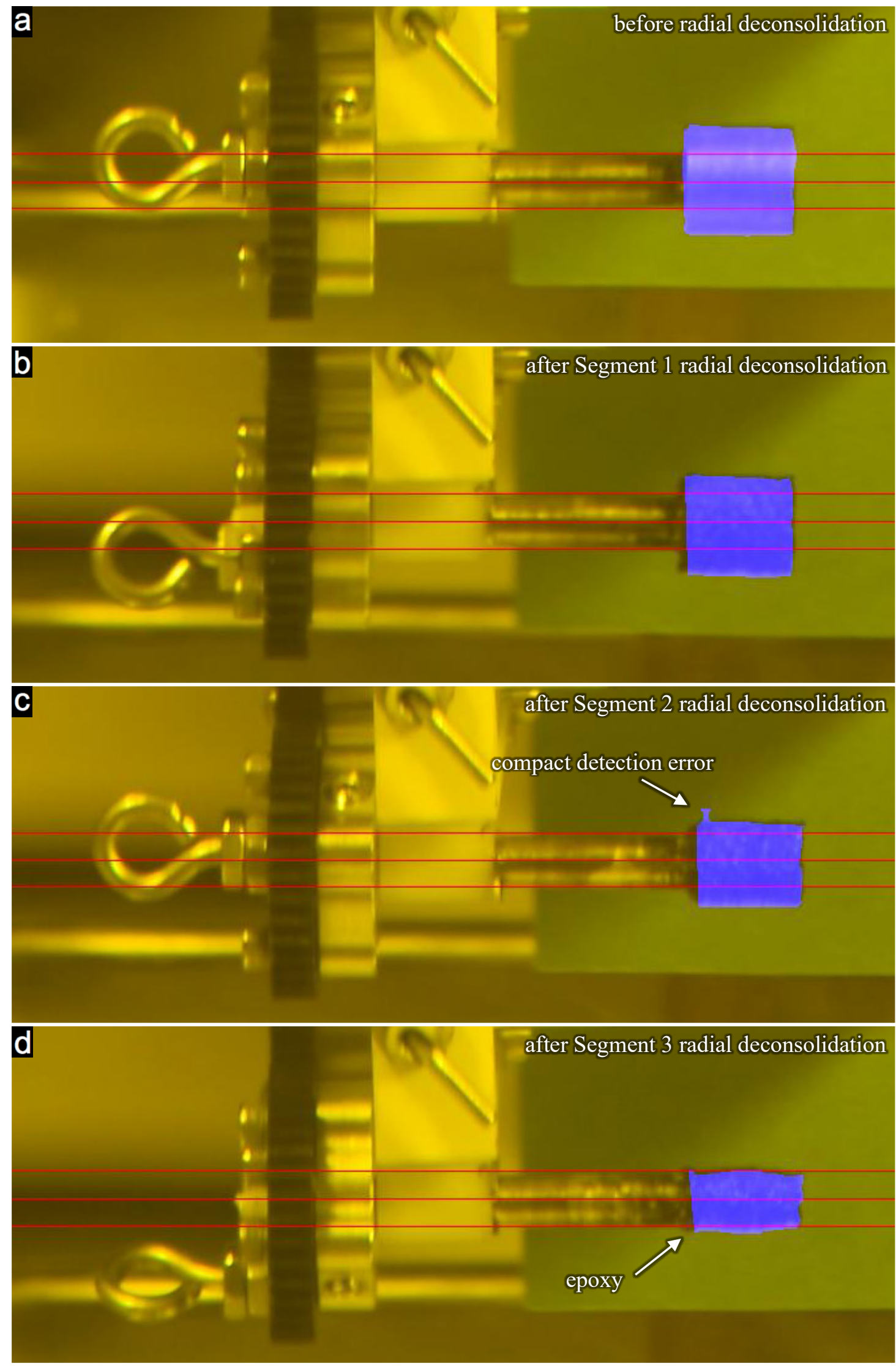

Figure 3-3. Examples of Compact 1-4 automated video analysis at each stage of radial deconsolidation. 
Table 3-4 compares the values determined for the initial diameter of each segment using automated image analysis of $\sim 50$ photos of the rotating compact vs. automated image analysis of $\sim 35$ frames from a $30 \mathrm{sec}$ video (every 51 frames). The average values for the initial diameter of Segment 1 are identical because the calibration factors (Table 3-3) were calculated from the average diameter of the whole compact in pixels, determined from the Segment 1 image set by each analysis, divided by the measured diameter of the as-irradiated compact. The difference in the standard deviations for the Segment 1 outer diameter was related to the pixel density of the acquired images, as previously discussed. This can be understood by considering the size of each pixel, in which a \pm 1 pixel uncertainty would correspond to $\pm 0.048 \mathrm{~mm}$ in the photo analysis and $\pm 0.15 \mathrm{~mm}$ in the video analysis. The video analysis results for the average outer diameters after each radial deconsolidation step yielded slightly higher values than the photo analysis results, but only by about one pixel. The average error in the measurements using either method is probably at least \pm 2 pixels. The difference in standard deviations in the outer diameters was less after radial deconsolidation, especially for Segment 4, in which the standard deviations were essentially the same. This indicated the photo analysis had sufficient pixel density to capture a real variation in the diameter around the circumference of the residual compact. The dimensional values obtained from the automated image analysis of the photos was used to process the LBL results discussed in Section 3.2.

Table 3-4. Comparison of analysis results for average initial diameter in $\mathrm{mm}$ for each Compact 1-4 segment

\begin{tabular}{lcccc}
\hline Analysis Method & Segment 1 & Segment 2 & Segment 3 & Segment 4 \\
\hline automated from photos & $12.227 \pm 0.016$ & $11.025 \pm 0.028$ & $9.282 \pm 0.039$ & $6.549 \pm 0.042$ \\
automated from video & $12.227 \pm 0.039$ & $11.154 \pm 0.055$ & $9.493 \pm 0.048$ & $6.665 \pm 0.049$ \\
\hline
\end{tabular}

Note: Plus/minus values are the standard deviation of the measurements of each image in the set.

\subsection{DLBL OF COMPACT 1-4}

After completion of the radial deconsolidation of each compact segment, the particles, matrix debris, and acid were transferred to a labeled storage vial. The beaker was rinsed several times, and the rinse was also added to the storage vial. The contents of each storage vial were sequentially analyzed using the process flow shown in Figure 2-1. The $6 \mathrm{~mol} / \mathrm{L}$ nitric acid used for deconsolidation was decanted off for separate analysis, and concentrated $(15.8 \mathrm{~mol} / \mathrm{L})$ nitric acid was used for the extractions and pot leaches. The details of the equipment and methods for Soxhlet extractor LBL have been previously reported (Hunn et al. 2013; Hunn and Montgomery 2020). The DLBL data for select actinides and fission products (both radionuclides and stable nuclides) is provided for each primary leach solution in Appendix A. In some cases, stable and radioactive isotopes of the same element were reported. The compact fraction data for ${ }^{133} \mathrm{Cs}$ and ${ }^{137} \mathrm{Cs}$ tended to agree closely, while ${ }^{134} \mathrm{Cs}$ was often lower. The ${ }^{140} \mathrm{Ce}$ compact fraction tended to track with, but somewhat exceed that of ${ }^{144} \mathrm{Ce}$, and the same was true for ${ }^{153} \mathrm{Eu}$ compared with ${ }^{154} \mathrm{Eu}$ and

${ }^{155} \mathrm{Eu}$. It is possible that ${ }^{133} \mathrm{Cs}$ and ${ }^{153} \mathrm{Eu}$ data were elevated by isobaric interferences. The stable ${ }^{109} \mathrm{Ag}$ nuclide provided some indication of silver behavior in the absence of measurable ${ }^{110 \mathrm{~m}} \mathrm{Ag}$, which had gone through too many half-lives prior to analysis. However previous comparisons have indicated a typically poor agreement between these two isotopes (Hunn et al. 2013).

Table 3-5 shows the particle equivalents of ${ }^{144}$ Ce detected in each DLBL solution. The first postburn particle leach from Compact 1-4 Segment 1 had 1.07 particle-equivalents of ${ }^{144} \mathrm{Ce}$, which indicated that a kernel from a driver fuel particle was exposed, possibly due to damage to the TRISO coating during particle handling in the IMGA. The actinides and fission products from this exposed kernel dominated the Segment 1 first postburn particle leach results for the actinides and radionuclides reported in Appendix Table A-1 and Appendix Table A-8. Therefore, the data from the Compact 1-4 Segment 1 postburn particle leaches should not be included in analyses focused on distribution of fission products from the DTF particles. The total ${ }^{144}$ Ce detected in the DLBL, not including the Segment 1 postburn particle leaches, was 19.9 particle equivalents. This was consistent with the presence of 20 DTF particles. Most of the ${ }^{144} \mathrm{Ce}$ in each segment was detected in the deconsolidation acid, and there was a clear trend in the total amount detected in each concentric cylindrical segment, which progressively decreased moving away 
from the core segment. This progression is shown graphically in Figure 3-4 in terms of the number of DTF particle equivalents detected in each segment.

Table 3-5. Particle equivalents of ${ }^{144}$ Ce detected in Compact 1-4 DLBL solutions

\begin{tabular}{lccccc}
\hline DLBL Step & Segment 1 & Segment 2 & Segment 3 & Segment 4 & Total \\
\hline Deconsolidation acid & $(0.075)$ & $(0.655)$ & $(0.938)$ & $(17.332)$ & $(19.000)$ \\
Preburn leach 1 & $<(0.0041)$ & $<(0.0031)$ & $<(0.0047)$ & $(0.143)$ & $(0.143)$ \\
Preburn leach 2 & $<(0.006)$ & $<(0.007)$ & $<(0.015)$ & $(0.054)$ & $(0.054)$ \\
Postburn matrix leach 1 & $(0.0064)$ & $(0.0067)$ & $(0.0047)$ & $(0.165)$ & $(0.183)$ \\
Postburn matrix leach 2 & $<(0.0017)$ & $<(0.003)$ & $<(0.0032)$ & $(0.0047)$ & $(0.0047)$ \\
Postburn particle leach 1 & $(1.073)$ & $<(0.037)$ & $<(0.020)$ & $(0.553)$ & $(1.626)$ \\
Postburn particle leach 2 & $<(0.0081)$ & $<(0.0068)$ & $<(0.0083)$ & $<(0.0086)$ & $(0.000)$ \\
\hline Pre-IMGA subtotal & $(0.081)$ & $(0.662)$ & $(0.943)$ & $(17.700)$ & $(19.385)$ \\
Post-IMGA subtotal & $(1.073)$ & $(0.000)$ & $(0.000)$ & $(0.553)$ & $(1.626)$ \\
Total & $(1.154)$ & $(0.662)$ & $(0.943)$ & $(18.253)$ & $(21.011)$ \\
Total without shaded values & $(0.081)$ & $(0.662)$ & $(0.943)$ & $(18.253)$ & $(19.938)$ \\
\hline
\end{tabular}

Note: Shaded values were associated with an exposed kernel from a driver fuel particle.

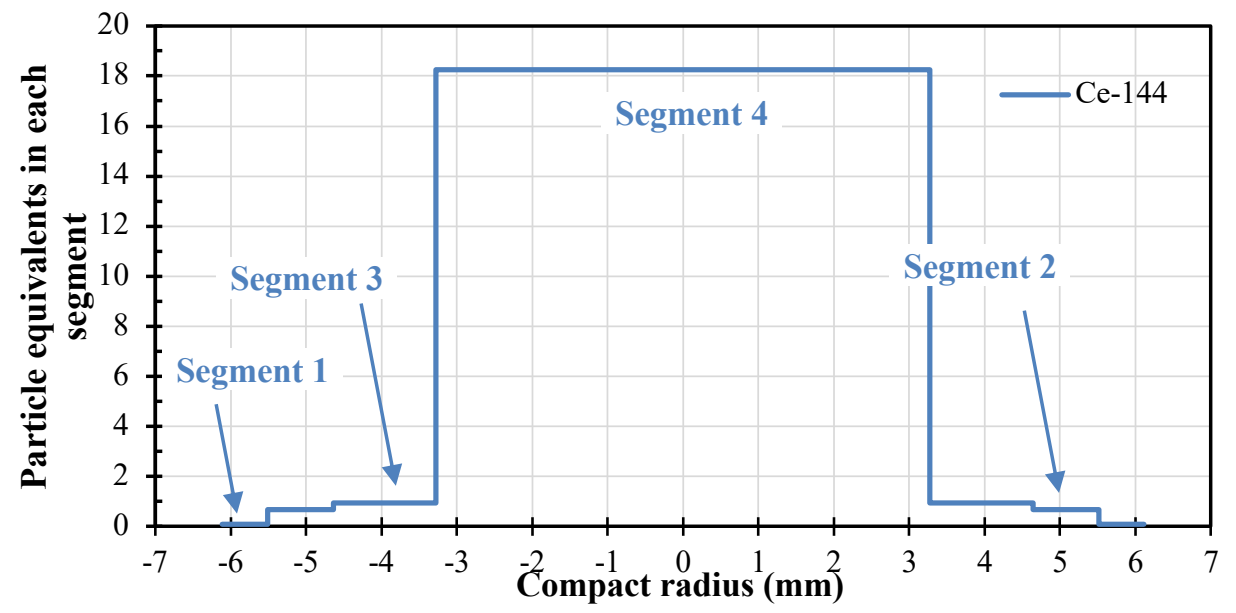

Figure 3-4. Distribution of ${ }^{144} \mathrm{Ce}$ from DTF particles in Compact 1-4 (Segment 1 post-burn particle leach not included).

For analysis of the diffusion of each nuclide, it is useful to convert the data into average concentration in each segment by dividing the nuclide quantity in each segment by the segment volume. Appendix Table A-22 contains concentration values for select actinides and fission products calculated from the total quantities detected in each Compact 1-4 segment and the segment volumes in Table 3-2 that were determined by the automated photo analysis. Figure 3-5 shows the ${ }^{144} \mathrm{Ce}$ data from Figure 3-4 scaled by the segment volume and plotted on a logarithmic scale. The arbitrary trend line shows the diffusion exhibited a roughly exponential nature, as might be expected, but the mathematical form of the concentration as a function of radius and the radial position in each segment that corresponded to the measured average concentration would have to be determined by further analysis beyond the scope of this report. The ${ }^{144} \mathrm{Ce}$ concentrations in Segment 2 and Segment 3 were similar, and Segment 2 did not align with the trend line in Figure 3-5. Figure 3-6 shows that the ${ }^{137} \mathrm{Cs}$ and ${ }^{154} \mathrm{Eu}$ concentrations exhibited the same peculiarity. Compared with ${ }^{144} \mathrm{Ce}$, the ${ }^{137} \mathrm{Cs}$ and ${ }^{154} \mathrm{Eu}$ concentrations were higher in the outer 3 segments. This was consistent with expectations that cesium and europium should be more mobile at the irradiation temperatures experienced by Compact 1-4 (Table 1-1). Figure 3-7 provides a comparison of the ${ }^{144} \mathrm{Ce},{ }^{235} \mathrm{U}$, and ${ }^{239} \mathrm{Pu}$ profiles. Cerium and uranium had similar profiles, while plutonium transport out of Segment 1 appeared to be relatively slower. 


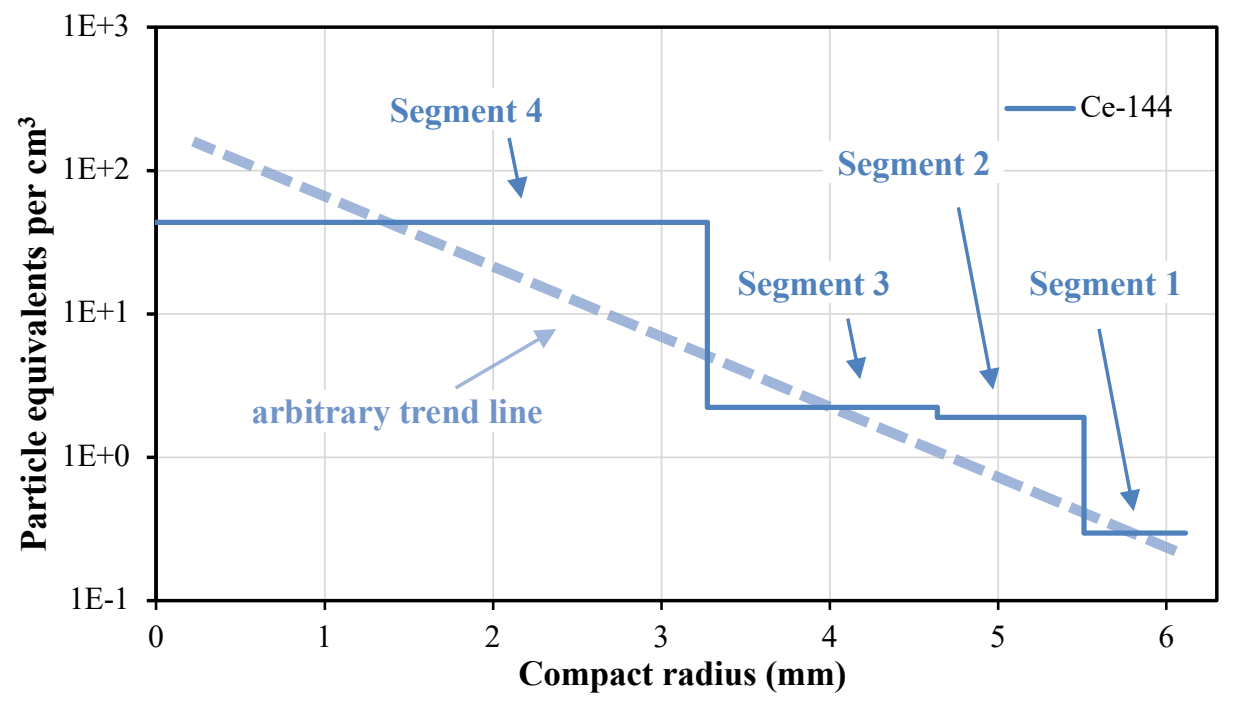

Figure 3-5. Concentration gradient of ${ }^{144} \mathrm{Ce}$ from DTF particles in Compact 1-4.

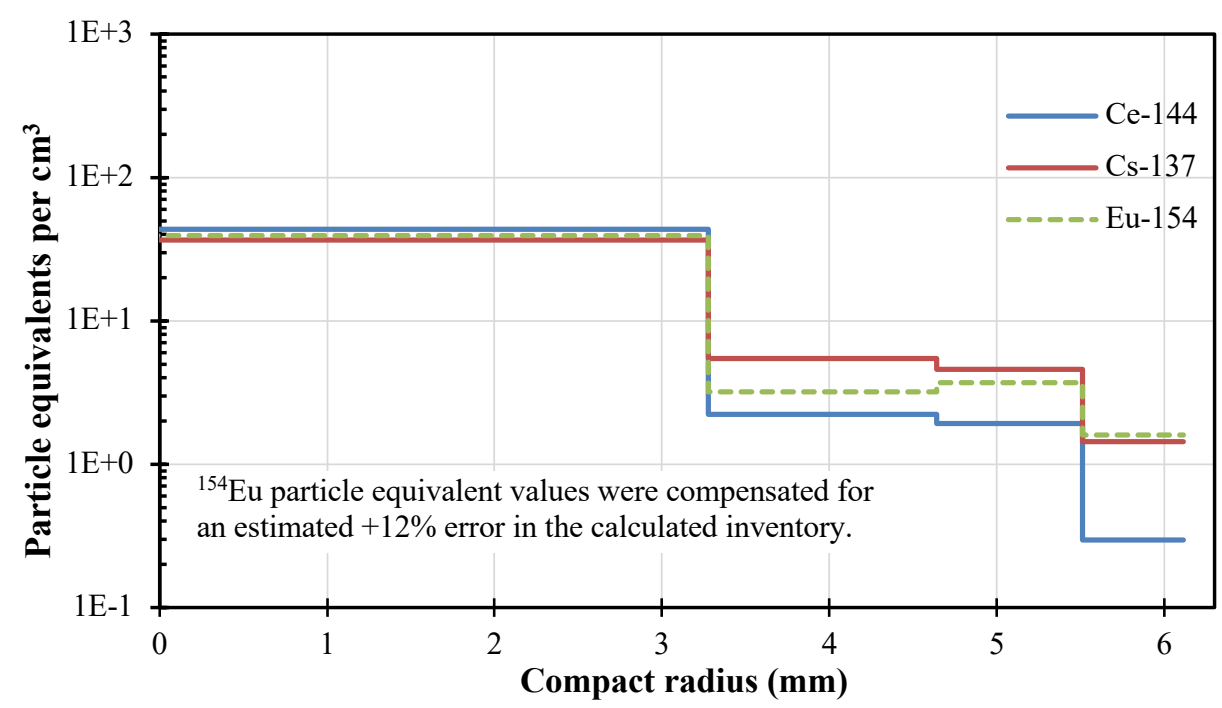

Figure 3-6. Comparison of ${ }^{144} \mathrm{Ce},{ }^{137} \mathrm{Cs}$, and ${ }^{154} \mathrm{Eu}$ diffusion from DTF particles in Compact 1-4.

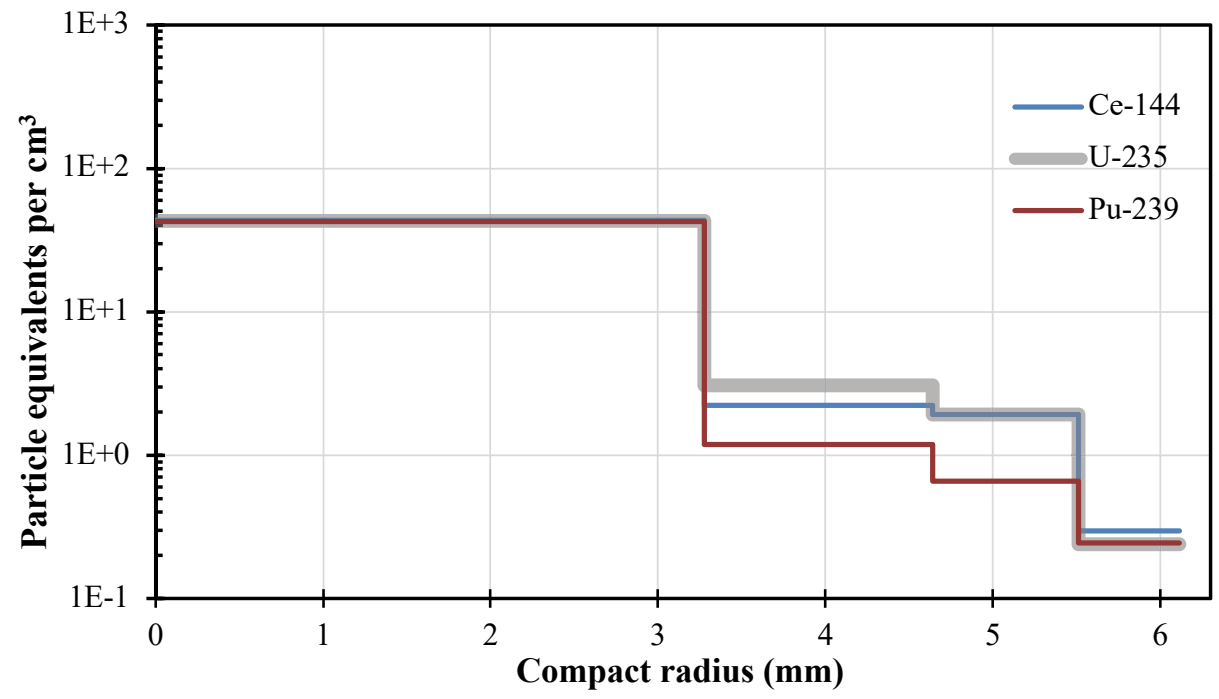

Figure 3-7. Comparison of ${ }^{144} \mathrm{Ce},{ }^{235} \mathrm{U}$, and ${ }^{239} \mathrm{Pu}$ diffusion from DTF particles in Compact 1-4. 


\subsection{IMGA EXAMINATION OF COMPACT 1-4}

As shown in Figure 2-1, driver fuel particles were separated from the matrix debris after the two preburn extractions by washing the acid and matrix debris through a sieve stack. Recovered particles were inspected under a stereoscope, imaged, and counted. The number of particles recovered from each segment were compared with a calculated value based on the segment volume and the assumptions that (1) the compact held the average number of particles (1898 driver fuel particles plus 20 DTF particles) and (2) the particles were evenly distributed. The actual number of particles in Segment 1 was higher than what was calculated using this assumption (Table 3-6), and this was not unexpected. Figure 1-1 and Figure 3-8 show that TRISO particles were packed more densely at the outer surface of the compacts. The Segment 1 thickness was less than the driver fuel particle diameter, but great enough for all particles near the surface to have been removed. It is likely that the residual surface after Segment 1 was removed was mostly matrix material and hollow cavities where near-surface particles had dropped out, which would have also contributed to the number of particles in Segment 2 being lower. Most of the particles from Segment 3 were lost when the hot cell operator knocked over the sieve stack during a cleaning operation. The lower particle count in the core section (444 actual vs. 550 calculated) was also not unexpected. Figure 1-1 shows larger matrix-only zones in the core, which were a result of the thicker overcoating applied to the DTF particles to help space them out axially (Hunn, Trammell, and Montgomery 2011). Recent progress in x-ray computed tomography and image analysis (Helmreich et al. 2018) make it possible to determine the particle distribution in the AGR-3/4 compacts more accurately. This will be pursued to refine the comparison of expected particle count with actual count, and may provide more confidence to the use of the optical analysis of compact diameter to determine radial deconsolidation volume. Higher fidelity DTF particle location data may also help with future diffusion analyses.

Table 3-6. Number of particles in Compact 1-4 segments

\begin{tabular}{|c|c|c|c|c|}
\hline Quantity & Segment 1 & Segment 2 & Segment 3 & Segment 4 \\
\hline Segment thickness (mm) & 0.60 & 0.87 & 1.37 & solid \\
\hline $\begin{array}{l}\text { Segment volume }\left(\mathrm{cm}^{3}\right) \text { measured with automated photo } \\
\text { analysis }\end{array}$ & 0.274 & 0.346 & 0.423 & 0.420 \\
\hline $\begin{array}{l}\text { Calculated number of particles assuming an even } \\
\text { distribution throughout the compact }\end{array}$ & 359 & 454 & 555 & 550 \\
\hline Actual number of particles recovered from each segment & 538 & 374 & $28^{a}$ & $444^{b}$ \\
\hline
\end{tabular}

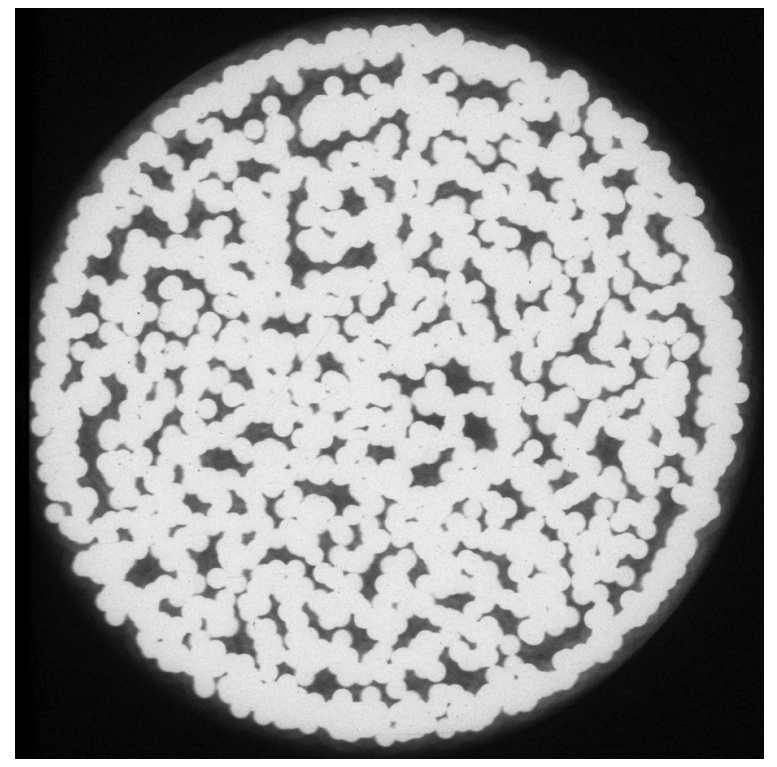

Figure 3-8. X-ray radiograph of AGR-3/4 compact. 
Figure 3-9 shows the results of the IMGA survey of particles from Compact 1-4 using a 1,200 s live count time, in which results from all segments were combined into a single histogram. Out of 1,364 driver fuel particles recovered from Compact 1-4, 1344 particles were counted with the IMGA. The other 20 likely dropped off in unrecoverable locations during the automated particle transfer between sample vials and the gamma counting position. This can happen when multiple particles are picked up either by two or three particles bridging the vacuum needle opening or by extra particles clinging to the particle on the tip. One particle (Particle 014-SP01) was identified in Segment 4 that had a low ${ }^{137} \mathrm{Cs} /{ }^{144} \mathrm{Ce}$ ratio, which was due to an above average ${ }^{144} \mathrm{Ce}$ count rather than a low ${ }^{137} \mathrm{Cs}$ count. This was automatically isolated for $4 \mathrm{~h}$ gamma counting, which revealed that the high ${ }^{144} \mathrm{Ce}$ count was simply a counting error due to the low activity of ${ }^{144} \mathrm{Ce}$ after about 7 half-lives (Appendix Table B-1). There were no indications for the presence of particles with failed $\mathrm{SiC}$ in any of the segments.

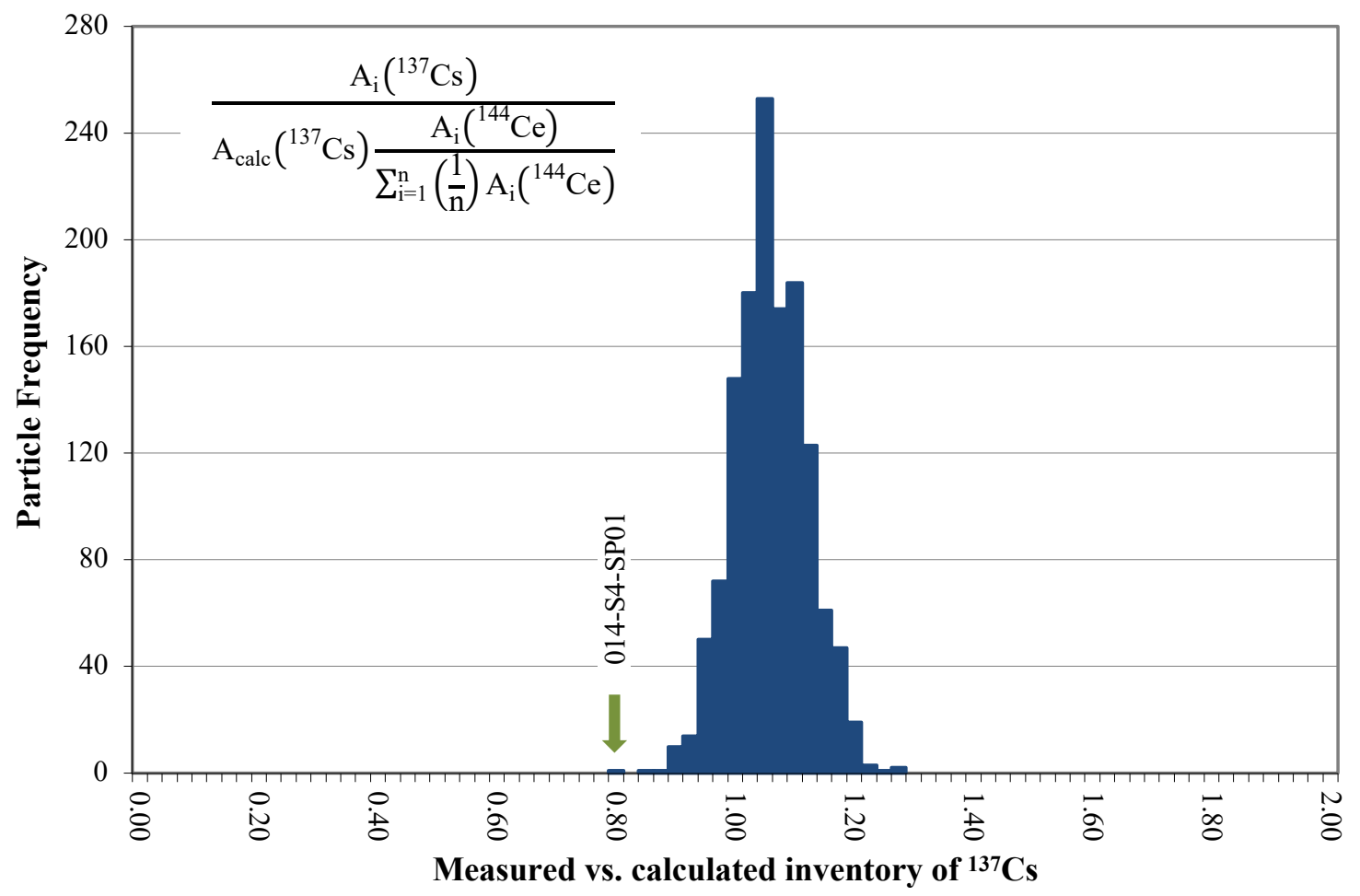

Figure 3-9. Measured vs. calculated ${ }^{137}$ Cs activity in 1344 particles from AGR-3/4 Compact 1-4.

After IMGA survey, 15 particles randomly-selected from each segment population were counted for $4 \mathrm{~h}$ each (along with Particle 014-S4-SP01). Results are documented in Appendix Table B-1, and Table 3-7 shows the means and standard deviations (SD) of the sample of 60 RS particles. No outliers were identified, and mean values were within the uncertainties in the analysis and calculated inventories $\left({ }^{125} \mathrm{Sb}\right.$ and ${ }^{154} \mathrm{Eu}$ means had the same offset related to error in the calculated inventory commonly observed in all AGR tests).

Table 3-7. Statistical summary of Compact 1-4 driver fuel particle activities

\begin{tabular}{lccccccc}
\hline & Value & ${ }^{106} \mathbf{R u}$ & ${ }^{125} \mathbf{S b}$ & ${ }^{{ }^{134}} \mathbf{C s}$ & ${ }^{137} \mathbf{C s}$ & ${ }^{144} \mathbf{C e}$ & ${ }^{154} \mathbf{E u}$ \\
\hline Mean & $\mathrm{Bq}$ & $4.01 \mathrm{E}+6$ & $9.44 \mathrm{E}+4$ & $9.35 \mathrm{E}+5$ & $1.87 \mathrm{E}+6$ & $2.78 \mathrm{E}+7$ & $2.85 \mathrm{E}+4$ \\
Mean & $\mathrm{M} / \mathrm{C}$ & 0.99 & 0.75 & 1.00 & 1.05 & 0.96 & 0.89 \\
SD & $\mathrm{Bq}$ & $10.5 \%$ & $8.7 \%$ & $9.2 \%$ & $8.1 \%$ & $7.7 \%$ & $9.9 \%$ \\
SD & $\mathrm{M} / \mathrm{C}$ & $4.3 \%$ & $3.8 \%$ & $2.3 \%$ & - & $1.7 \%$ & $3.3 \%$ \\
\hline
\end{tabular}




\section{AGR-3/4 COMPACT 10-4}

\subsection{RADIAL DECONSOLIDATION AND DIMENSIONAL ANALYSIS OF COMPACT 10-4}

Compact 10-4 was radially deconsolidated in two stages to remove two cylindrical rings of driver fuel particles and matrix, leaving a cylindrical core encompassing the DTF particles, which was then axially deconsolidated. The original segment plan was to generate four segments of equal volume, as shown in Table 4-1. However, an issue arose during the first deconsolidation, in which the wedge that resides behind the drag paddle to keep the Pt screen pressed against the compact was hung up on the beaker. As with Compact 1-4, radial deconsolidation was paused several times during each deconsolidation stage to obtain a photo, which was manually examined to evaluate progress toward the target diameter for the segment. However, because the screen was not pressed against the paddle, some deconsolidated material was not removed, and this made it appear that the Segment 1 target diameter had not been reached. When the radial deconsolidation was resumed with the wedge correctly positioned, the already deconsolidated material was quickly removed, and the Segment 1 target diameter was exceeded. Due to the overshoot of the first segment target diameter, new targets were calculated to produce three roughly equal segments. As was done for Compact 1-4, at least 50 photos and a $30 \mathrm{~s}$ video were acquired of the rotating residual at the end of each radial deconsolidation. Table 4-2 shows the actual segment dimensions and volumes as determined by automated image analysis of the photos (discussed below); the time that deconsolidation was active (power applied) for each radially deconsolidated segment is also shown.

Table 4-1. Equal volume segment plan for Compact 10-4

\begin{tabular}{lcccc}
\hline Quantity & Segment 1 & Segment 2 & Segment 3 & Segment 4 \\
\hline Initial diameter $(\mathrm{mm})$ & 12.15 & 10.52 & 8.59 & 6.08 \\
Target diameter $(\mathrm{mm})$ & 10.52 & 8.59 & 6.08 & 0 \\
Segment thickness $(\mathrm{mm})$ & 0.81 & 0.97 & 1.26 & solid \\
Segment volume $\left(\mathrm{cm}^{3}\right)$ & 0.36 & 0.36 & 0.36 & 0.36 \\
\hline
\end{tabular}

Note: Average diameter of the irradiated compact was $12.152 \mathrm{~mm}$ with a standard deviation of $0.009 \mathrm{~mm}$, and length from a single measurement was $12.433 \mathrm{~mm}$ (Stempien et al. 2016).

Table 4-2. Segment results for Compact 10-4 measured with automated photo analysis

\begin{tabular}{lccc}
\hline Quantity & Segment 1 & Segment 2 & Segment 3 \\
\hline Initial diameter $(\mathrm{mm})$ & 12.15 & 9.62 & 7.14 \\
Residual diameter $(\mathrm{mm})$ & 9.62 & 7.14 & 0 \\
Segment thickness $(\mathrm{mm})$ & 1.26 & 1.24 & solid \\
Segment volume $\left(\mathrm{cm}^{3}\right)$ & 0.54 & 0.41 & 0.50 \\
Deconsolidation time (min) & 61 & 22 & \\
\hline
\end{tabular}

Photos of the compact at each stage in the process are shown in Figure 4-1. As for Compact 1-4, material removal was relatively uniform along the length and around the circumference of the compact. The nylon threaded rod shown in Figure 4-1 was inserted into the hollow axle tube as part of the mounting process. To bond the compact to the rod, conducting epoxy was packed into half the axle and the nylon threaded rod inserted until in contact with the epoxy. A nylon nut on the rod prevented it from pressing on the epoxy. The axle was loaded into the hot cell, and the sample holder (axle, gear, and bracket) was assembled (Figure 1-3). The compact and axle were loaded into a mounting jig developed at INL to align the axle to the center of the compact (Stempien 2017). The axle was placed in contact with the compact to provide electrical connection during axial deconsolidation (Figure 1-4), the nylon nut was backed off about one turn, and pressed into the axle. This ejected an easily metered small volume of epoxy, which squeezed through slots in the end of the axle and formed a small tapered bead at the joining (Figure 4-1). 

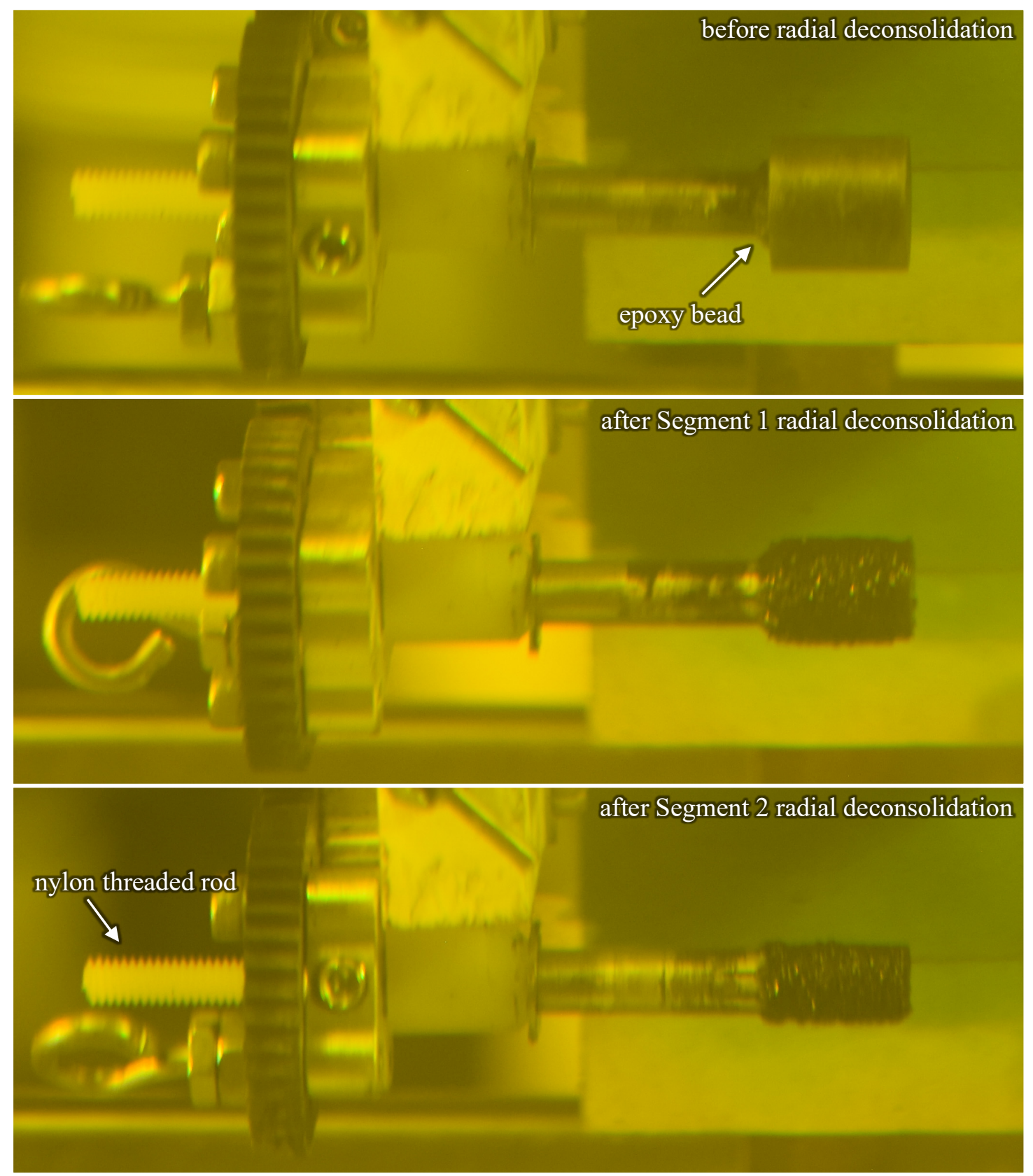

Figure 4-1. Compact 10-4 at each stage of radial deconsolidation.

Automated image analysis was accomplished using a custom MATLAB script as described in Section 3.1. As for Compact 1-4, in lieu of calibrating each image using the axle diameter, the average diameter of the as-irradiated compact of $12.152 \mathrm{~mm}$, which was measured with a micrometer during early AGR-3/4 PIE (Stempien et al. 2016), was used to calibrate the images. While all images of the Compact 1-4 segments were acquired with a consistent image magnification, this was not the case for Compact 10-4. As for the Compact 1-4 image analysis, the pixel height of the removable support block shown in Figure 1-2, was measured in each image set. The photos of the as-irradiated compact used to establish the calibration and those of the residual compact after Segment 1 were consistent to \pm 1 pixel (1113-1114). The pixel height of the removable support block in the Segment 2 photos was 1\% lower (1102). Therefore, a 1\% adjustment was applied to the calibration factor to correct for the magnification difference. Table 4-3 shows the average and standard deviation of the calibration factors used for the analysis. 
Table 4-3. Calibration factors in pixels/mm used for Compact 10-4 image analysis

\begin{tabular}{lcc}
\hline Calibration Source & Analysis Method & Before Segment 1 \\
\hline Whole compact & automated from photos & $22.468 \pm 0.104$ \\
Whole compact & automated from video & $7.221 \pm 0.030$ \\
\hline Note: Plus/minus values are the standard deviation of the measurements of each calibration factor.
\end{tabular}

Figure 4-2 shows an example of the output images from the automated photo analyses for each stage of radial deconsolidation, and Figure 4-3 shows examples of the automated video analyses. The blue overlay shows what the image analysis identified as part of the compact. The left edge of the blue field is truncated based on a user defined search area. The left side of the as-irradiated compact was intentional left out to avoid problems related with the shadow on the green screen. As with Compact 1-4, analysis results were manually inspected, and flawed results discarded.

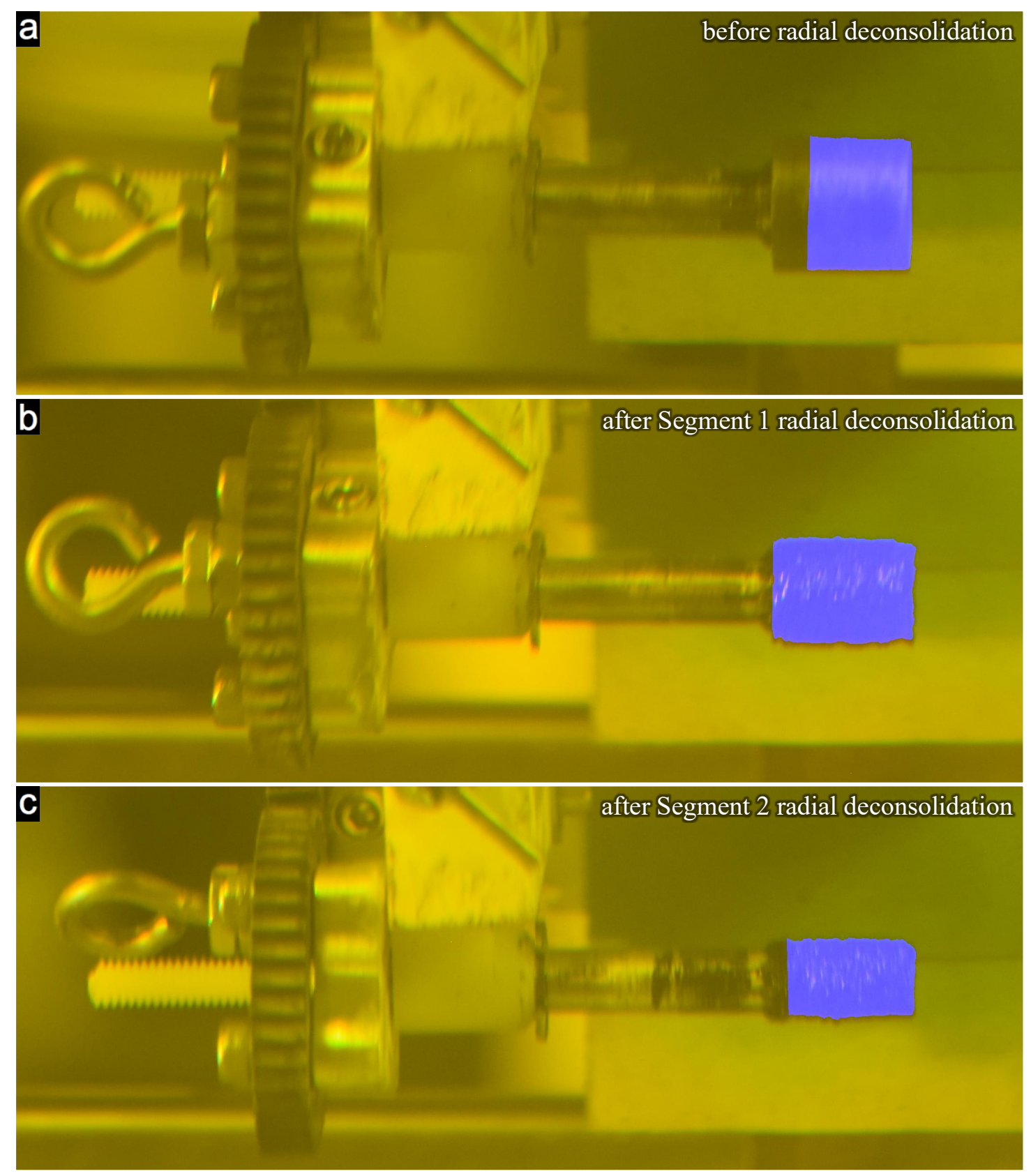

Figure 4-2. Examples of Compact 10-4 automated photo analysis at each stage of radial deconsolidation. 


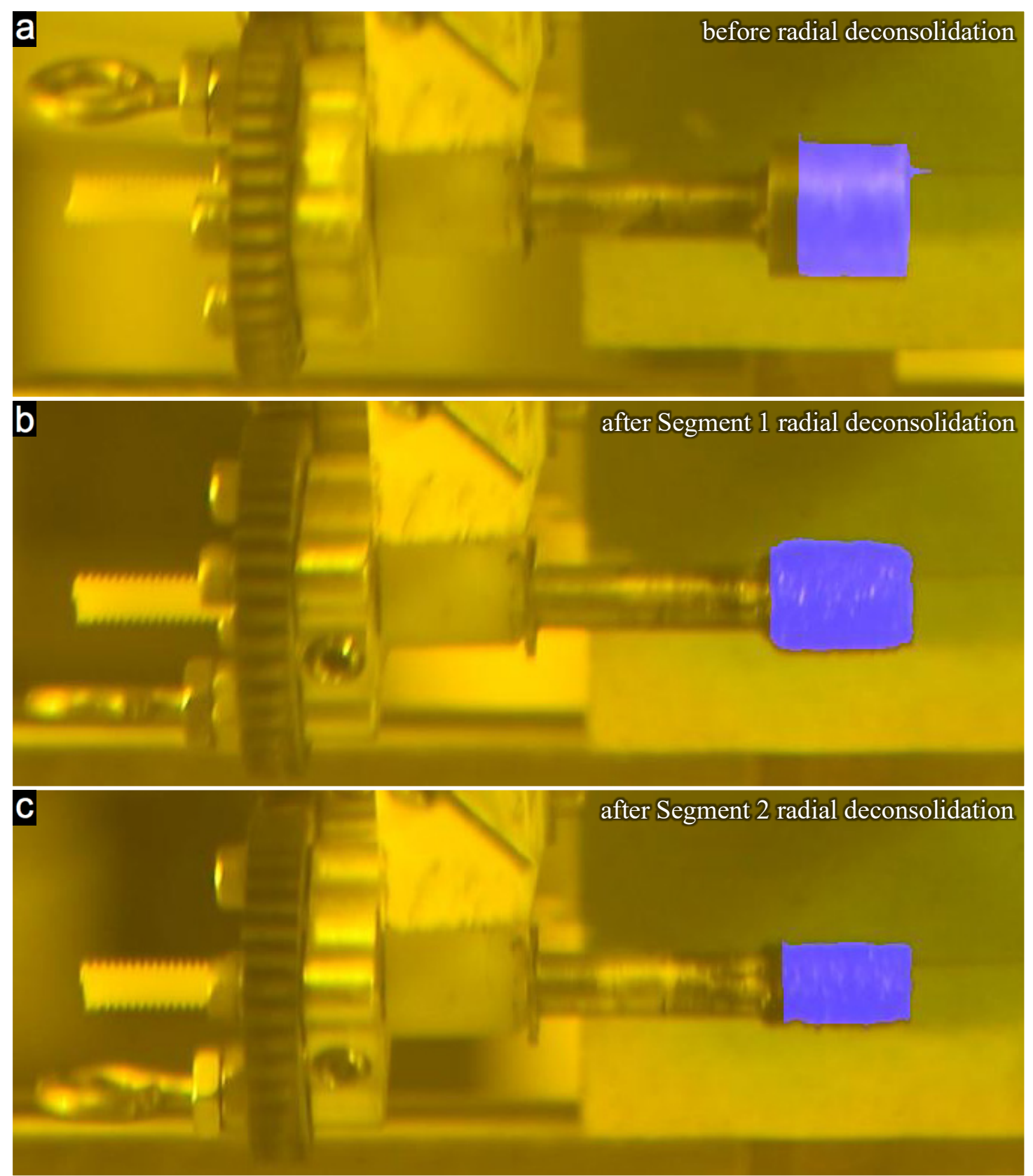

Figure 4-3. Examples of Compact 10-4 automated video analysis at each stage of radial deconsolidation.

Table 4-4 compares the values determined for the initial diameter of each segment using automated image analysis of 50-60 photos of the rotating compact vs. automated image analysis of 30-60 video frames. Results from manual analysis of 10 images are also included in the table for verification. Average values were in good agreement, but the standard deviations were noticeably higher than for the Compact 1-4 analyses (Table 3-4). This was due to the poorer focus, which is evident if Figure 4-2 and Figure 4-3 are compared with Figure 3-2 and Figure 3-3, respectively. A different lens with higher zoom has been acquired for future radial deconsolidation, which should help with this issue if combined with better lighting. The dimensional values obtained from the automated image analysis of the photos was used to process the LBL results discussed in Section 4.2. 
Table 4-4. Comparison of analysis results for initial diameter in $\mathrm{mm}$ for each Compact 10-4 segment

\begin{tabular}{lccc}
\hline Analysis Method & Segment 1 & Segment 2 & Segment 3 \\
\hline automated from photos & $12.152 \pm 0.056$ & $9.622 \pm 0.060$ & $7.069 \pm 0.085$ \\
automated from video & $12.152 \pm 0.051$ & $9.742 \pm 0.067$ & $7.125 \pm 0.142$ \\
manual from photos & $12.152 \pm 0.065$ & $9.733 \pm 0.106$ & $7.168 \pm 0.085$ \\
\hline Note: Plus/minus values are the standard deviation of the measurements of each image in the set.
\end{tabular}

\subsection{DLBL OF COMPACT 10-4}

After completion of the radial deconsolidation of each Compact 10-4 segment, the particles and matrix debris were subjected to the same DLBL process applied to the material from Compact 1-4. The DLBL data for select actinides and fission products (both radionuclides and stable nuclides) is provided for each primary leach solution in Appendix A. Table 4-5 shows the particle equivalents of ${ }^{235} \mathrm{U}$ detected in each DLBL solution. The total ${ }^{235} \mathrm{U}$ detected in the DLBL was 21.0 particle equivalents. This was consistent with the presence of 20 DTF particles. There is insufficient data to determine whether the apparent one "extra" particle equivalent was measurement uncertainty or a contribution from the Compact 1-4 driver fuel; it was likely the former, given the variation observed between the ${ }^{235} U$ and ${ }^{238} \mathrm{U}$ isotopes (Appendix A). Most of the ${ }^{235} \mathrm{U}$ in each segment was detected in the deconsolidation acid, and there was a clear trend in the total amount detected in each concentric cylindrical segment, which progressively decreased moving away from the core segment. This progression is shown graphically in Figure 4-4 in terms of the number of DTF particle equivalents detected in each segment.

Table 4-5. Particle equivalents of ${ }^{235} \mathrm{U}$ detected in Compact 10-4 DLBL solutions

\begin{tabular}{lcccc}
\hline DLBL Step & Segment 1 & Segment 2 & Segment 3 & Total \\
\hline Deconsolidation acid & $(0.188)$ & $(0.830)$ & $(19.416)$ & $(20.433)$ \\
Preburn leach 1 & $(0.0013)$ & $(0.016)$ & $(0.342)$ & $(0.360)$ \\
Preburn leach 2 & $(0.0009)$ & $(0.0055)$ & $(0.012)$ & $(0.018)$ \\
Postburn matrix leach 1 & $(0.018)$ & $(0.0083)$ & $(0.050)$ & $(0.077)$ \\
Postburn matrix leach 2 & $(0.0008)$ & $(0.0021)$ & $(0.0019)$ & $(0.0048)$ \\
Postburn particle leach 1 & $(0.022)$ & $(0.021)$ & $(0.042)$ & $(0.085)$ \\
Postburn particle leach 2 & $(0.0031)$ & $(0.0021)$ & $(0.014)$ & $(0.019)$ \\
\hline Pre-IMGA subtotal & $(0.209)$ & $(0.862)$ & $(19.822)$ & $(20.893)$ \\
Post-IMGA subtotal & $(0.025)$ & $(0.023)$ & $(0.056)$ & $(0.104)$ \\
Total & $(0.234)$ & $(0.885)$ & $(19.878)$ & $(20.997)$ \\
\hline
\end{tabular}

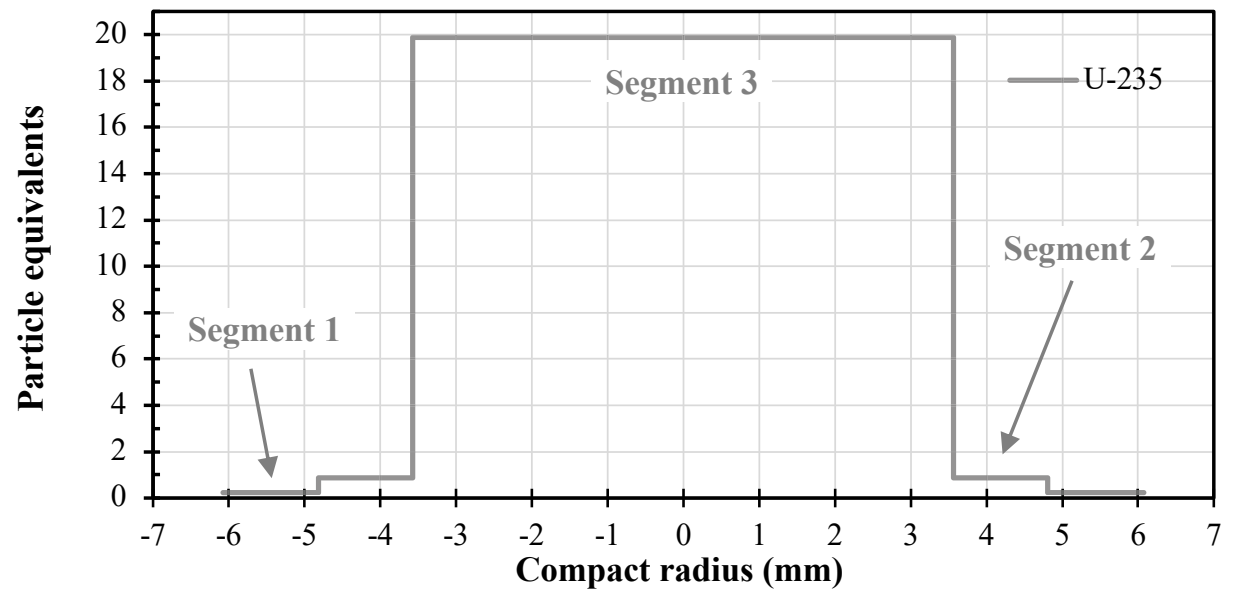

Figure 4-4. Distribution of ${ }^{235} \mathrm{U}$ from DTF particles in Compact 10-4. 
Appendix Table A-23 contains concentration values for select actinides and fission products calculated from the total quantities detected in each Compact 10-4 segment and the segment volumes in Table 4-2 that were determined by the automated photo analysis. Figure 4-5 shows the ${ }^{235} \mathrm{U}$ data from Figure 4-4 scaled by the segment volume and plotted on a logarithmic scale. The arbitrary trend line shows the diffusion exhibited a roughly exponential nature, as might be expected, but the mathematical form of the concentration as a function of radius and the radial position in each segment that corresponded to the measured average concentration would have to be determined by further analysis beyond the scope of this report. Figure 4-6 provides a comparison of the ${ }^{144} \mathrm{Ce},{ }^{235} \mathrm{U}$, and ${ }^{239} \mathrm{Pu}$ profiles. Uranium and plutonium had similar profiles, while cerium transport appeared to be relatively slower. Figure $4-7$ shows that ${ }^{137} \mathrm{Cs}$ and ${ }^{154} \mathrm{Eu}$ exhibited indications of more active diffusion, with noticeable depletion of their total inventory and higher concentration in the outer two segments. The ${ }^{137} \mathrm{Cs}$ and ${ }^{154} \mathrm{Eu}$ concentrations were also higher in the outer 3 segments from Compact 1-4 (Figure 3-6), but the depletion in the core segment was less severe. This difference was most likely related to the fact that Compact 10-4 was irradiated at a higher temperature and safety tested at $1,400^{\circ} \mathrm{C}$ after the irradiation (Table 1-1). Table $4-6$ shows the particle equivalents of these nuclides measured with DLBL in each segment.

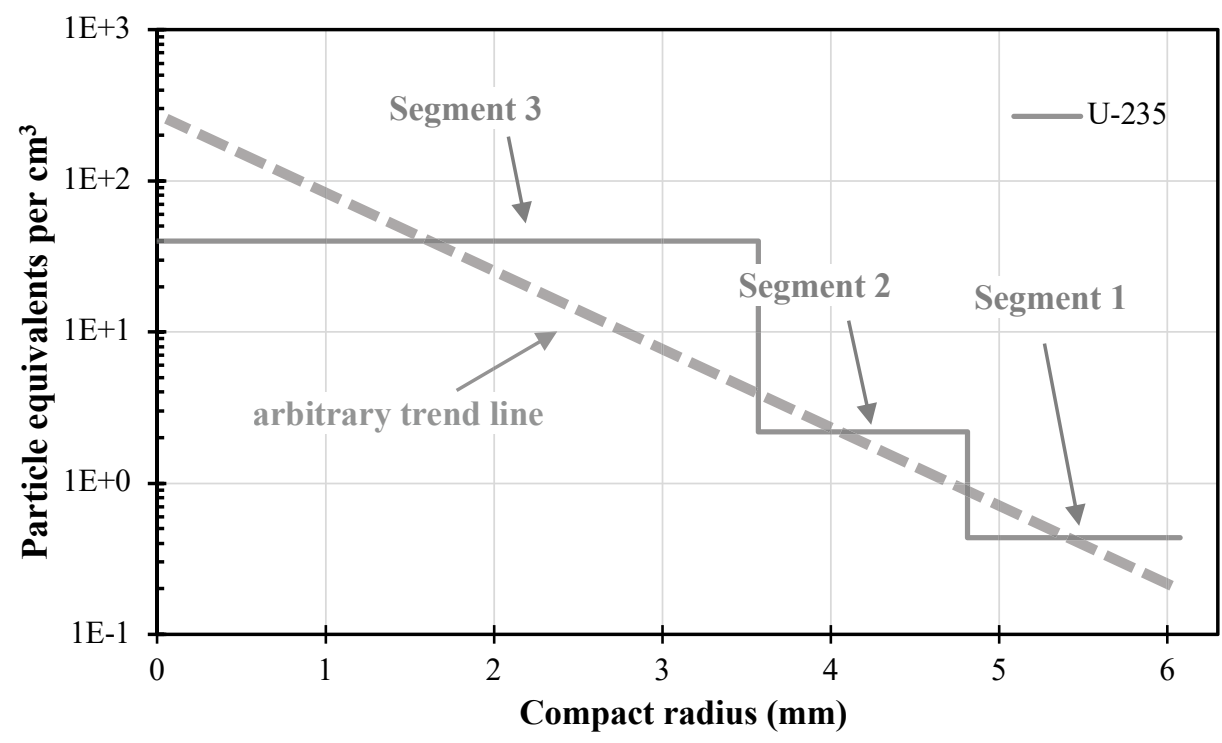

Figure 4-5. Concentration gradient of ${ }^{235} \mathrm{U}$ from DTF particles in Compact 10-4.

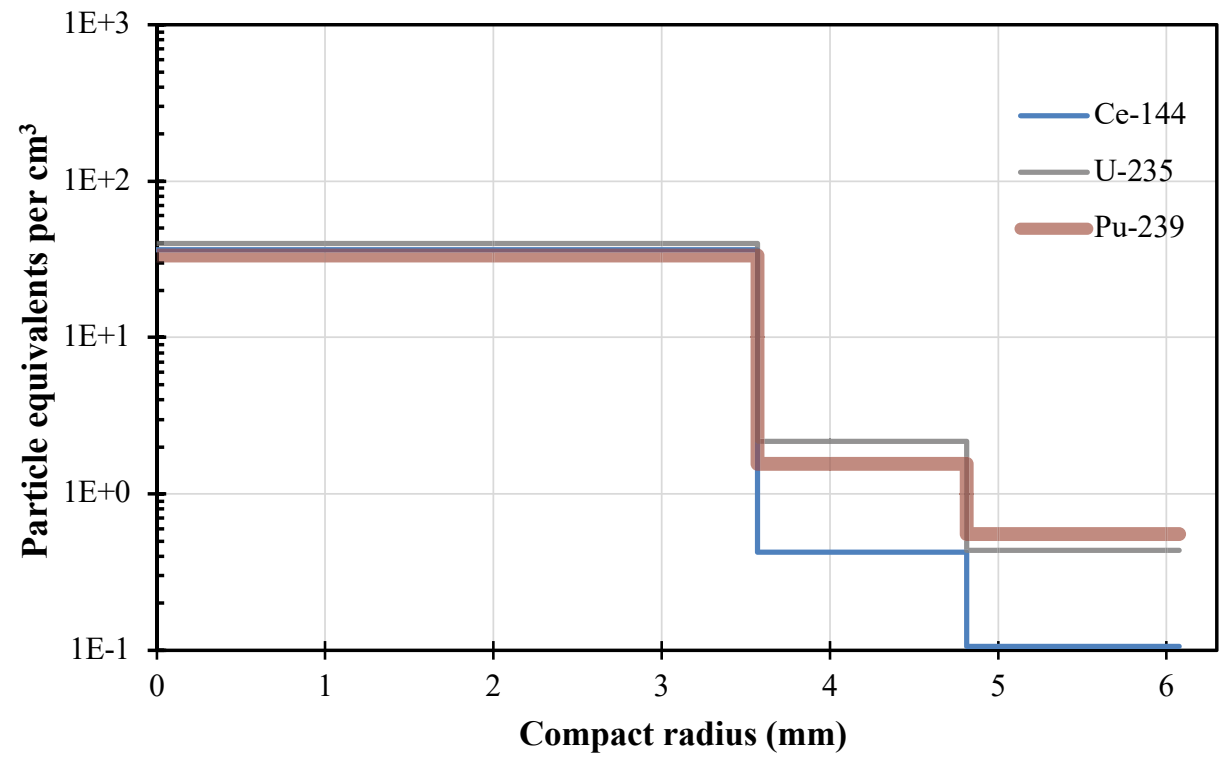

Figure 4-6. Comparison of ${ }^{144} \mathrm{Ce},{ }^{235} \mathrm{U}$, and ${ }^{239} \mathrm{Pu}$ diffusion from DTF particles in Compact 10-4. 


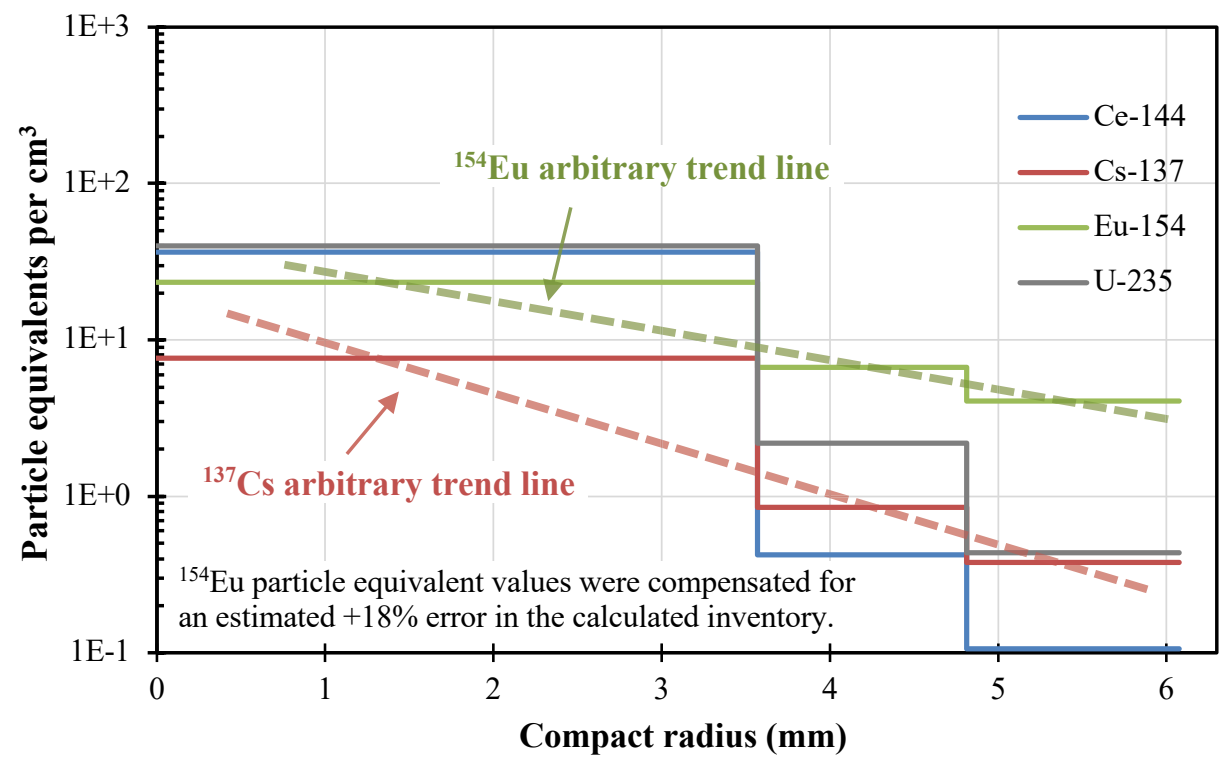

Figure 4-7. Comparison of ${ }^{144} \mathrm{Ce},{ }^{137} \mathrm{Cs}$, and ${ }^{154} \mathrm{Eu}$ diffusion from DTF particles in Compact 10-4.

Table 4-6. Comparison of particle equivalents of select nuclides in Compact 10-4 segments

\begin{tabular}{lcccc}
\hline Nuclide & Segment $\mathbf{1}$ & Segment 2 & Segment 3 & Total \\
\hline${ }^{235} \mathrm{U}$ & $(0.234)$ & $(0.885)$ & $(19.878)$ & $(20.997)$ \\
${ }^{144} \mathrm{Ce}$ & $(0.057)$ & $(0.172)$ & $(18.139)$ & $(18.368)$ \\
${ }^{239} \mathrm{Pu}$ & $(0.298)$ & $(0.630)$ & $(16.653)$ & $(17.581)$ \\
${ }^{90} \mathrm{Sr}$ & $(1.973)$ & $(2.452)$ & $(9.915)$ & $(14.341)$ \\
${ }^{154} \mathrm{Eu}{ }^{a}$ & $(1.850)$ & $(2.291)$ & $(9.834)$ & $(13.975)$ \\
${ }^{137} \mathrm{Cs}$ & $(0.203)$ & $(0.346)$ & $(3.806)$ & $(4.356)$ \\
\hline
\end{tabular}

${ }^{a}$ Values for ${ }^{154} \mathrm{Eu}$ were adjusted for offset in calculated inventory

\subsection{IMGA EXAMINATION OF COMPACT 10-4}

Compact 10-4 driver fuel particles were separated from the matrix debris, inspected under a stereoscope, imaged, and counted. Table 4-7 compares the number of particles recovered from each segment with a calculated number determined as described in Section 3.3. The actual number of particles in Segment 1 was close to what was calculated. This was different from what was observed for Compact 1-4, and consistent with the discussion of why Compact 1-4 Segment 1 had more than the calculated number. The greater thickness of Compact 10-4 Segment 1, compared with Compact 1-4 Segment 1 (Table 3-6), included the higher density of near-surface particles and the higher density of matrix material below the near-surface particles. This evened out the variation created when particles align along the die walls during compacting and overcoat, which cannot move outward beyond the die walls, preferentially moves inward. Figure 3-8 shows these two zones of denser and sparser particle population near the compact surface. The total number of particles recovered for IMGA was 134 particles short of the average number per AGR-3/4 compact, which suggests particles were lost somewhere in the process.

Table 4-7. Number of particles in Compact 10-4 segments

\begin{tabular}{lccc}
\hline Quantity & Segment 1 & Segment 2 & Segment 4 \\
\hline Segment thickness $(\mathrm{mm})$ & 1.26 & 1.24 & solid \\
Segment volume $\left(\mathrm{cm}^{3}\right)$ measured with automated photo analysis & 0.538 & 0.406 & 0.498 \\
Calculated number of particles assuming an even distribution & 715 & 540 & 662 \\
Actual number of particles recovered from each segment & 730 & 497 & $557^{a}$ \\
\hline
\end{tabular}

${ }^{a}$ The 20 DTF particles were added to the counted number of driver fuel particles recovered from the core segment. 
Figure 3-9 shows the results of the individual IMGA surveys of particles from each segment combined into a single histogram. Two particles in Segment 1 (Particle 104-S1-SP01 and Particle 104-S1-SP02) were culled out in accordance with the IMGA particle sorting algorithms, and both had calculated ${ }^{137} \mathrm{Cs}$ $\mathrm{M} / \mathrm{C}$ values above 2. Particle 104-S1-SP01 had very low measured activities of both ${ }^{137} \mathrm{Cs}$ and ${ }^{144} \mathrm{Ce}$, and may have been a chunk of matrix debris. Particle 104-S1-SP02 had above average ${ }^{137} \mathrm{Cs}$ activity and below average ${ }^{144}$ Ce activity. Three particles in Segment 3, Particle 104-S3-SP01, Particle 104-S3-SP02, and Particle 104-S3-SP03, were also culled out. These three particles all had unmeasurable ${ }^{137} \mathrm{Cs}$ activity. Particle 104-S3-SP01 and Particle 104-S3-SP02 had below average ${ }^{144} \mathrm{Ce}$ activity, while Particle 104-S3-SP03 had above average ${ }^{144} \mathrm{Ce}$ activity. All five particles were gamma counted for $4 \mathrm{~h}$, and results are shown in Appendix Table B-2. Particle 104-S1-SP02 had activities that indicated it probably came from an AGR-2 irradiated compact. The measurable activities associated with the other special particles suggest that they were just matrix material. There were no indications that these could be failed TRISO. Further analysis of the special particles is planned and will confirm these current hypotheses.

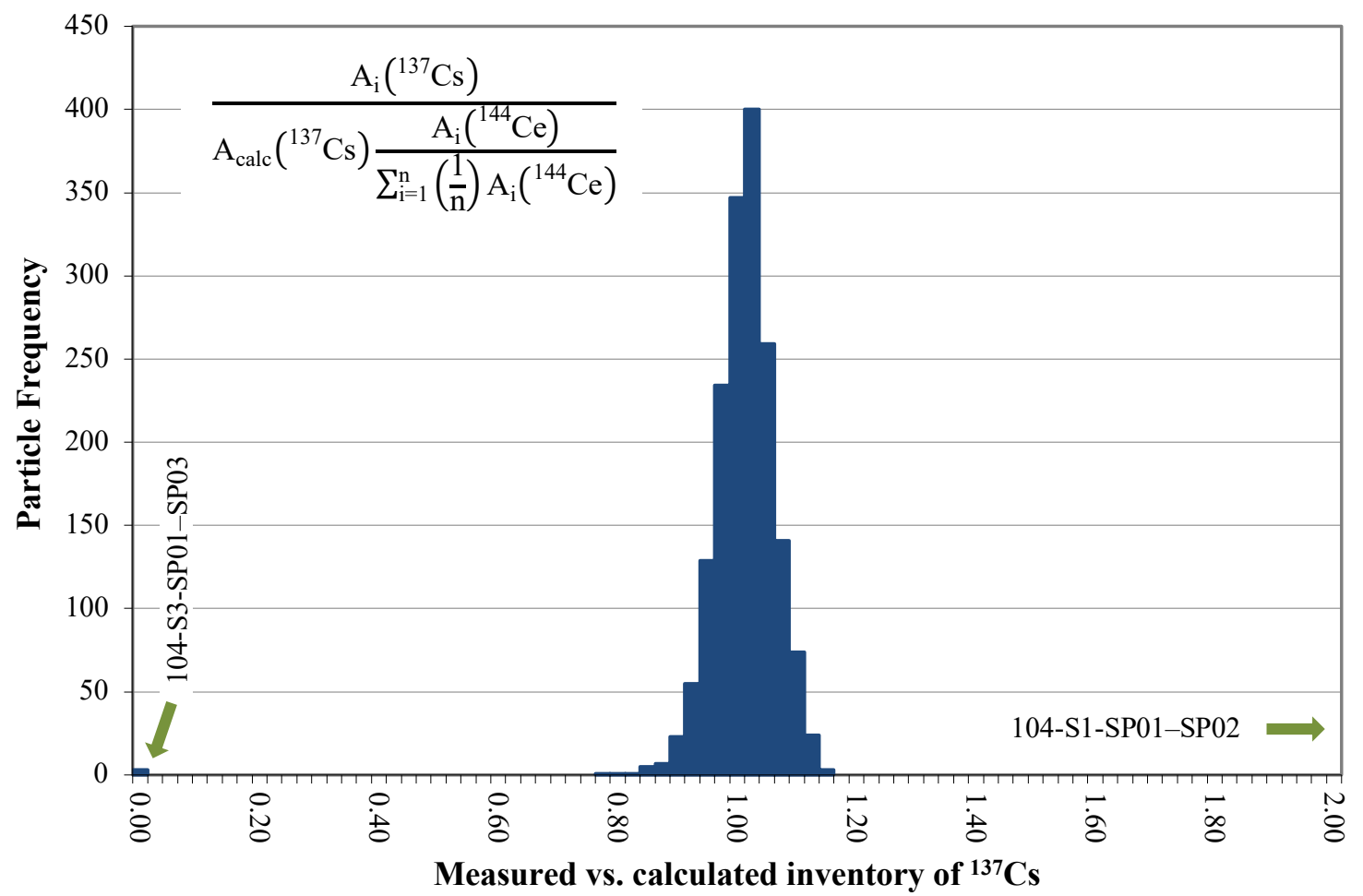

Figure 4-8. Measured vs. calculated ${ }^{137}$ Cs activity in 1705 particles from AGR-3/4 Compact 10-4.

After IMGA survey, 15 particles randomly-selected from each segment population were counted for $4 \mathrm{~h}$ each. Results are documented in Appendix B and Table 3-7 shows the means and standard deviations of the sample of 45 RS particles. No outliers were identified, and mean values were within the uncertainties in the analysis and calculated inventories $\left({ }^{125} \mathrm{Sb}\right.$ and ${ }^{154} \mathrm{Eu}$ means had the same offset related to error in the calculated inventory commonly observed in all AGR tests).

Table 4-8. Statistical summary of Compact 10-4 driver fuel particle activities

\begin{tabular}{lccccccc}
\hline & Value & ${ }^{106} \mathbf{R u}$ & ${ }^{125} \mathbf{S b}$ & ${ }^{134} \mathbf{C s}$ & ${ }^{137} \mathbf{C s}$ & ${ }^{144} \mathbf{C e}$ & ${ }^{154} \mathbf{E u}$ \\
\hline Mean & $\mathrm{Bq}$ & $9.65 \mathrm{E}+6$ & $1.59 \mathrm{E}+5$ & $2.74 \mathrm{E}+6$ & $3.02 \mathrm{E}+6$ & $4.86 \mathrm{E}+7$ & $7.91 \mathrm{E}+4$ \\
Mean & $\mathrm{M} / \mathrm{C}$ & 1.10 & 0.70 & 0.97 & 1.01 & 1.06 & 0.85 \\
SD & $\mathrm{Bq}$ & $9.1 \%$ & $9.1 \%$ & $9.3 \%$ & $9.8 \%$ & $7.2 \%$ & $8.9 \%$ \\
SD & $\mathrm{M} / \mathrm{C}$ & $4.5 \%$ & $5.4 \%$ & $2.1 \%$ & - & $4.1 \%$ & $3.5 \%$ \\
\hline
\end{tabular}




\section{CONCLUSIONS}

Two compacts from the AGR-3/4 irradiation were subjected to radial DLBL and particles were examined with the ORNL IMGA. Compact 1-4 was from the capsule located at the bottom of the test train and experienced burnup and temperatures near the lower end of the ranges for compacts in the AGR-3/4 irradiation test. Compact 10-4 experienced irradiation burnup and temperatures near the middle of the ranges and was safety tested at $1,400^{\circ} \mathrm{C}$ prior to radial deconsolidation.

Radial deconsolidation was successfully executed on both compacts with some challenges related to stopping the deconsolidation of each segment at the exact target diameter. Radial uniformity across the compact was excellent (Figure 3-1 and Figure 4-1). Automated image analysis was applied to both photos and videos of the rotating residual after completion of the radial deconsolidation of each segment. Insufficient lighting and marginal resolution challenged the image analysis program, added the need for tedious manual verification of results, and limited the accuracy of the diameter measurement. These deficiencies will be addressed before the next run. Use of the mounting axle as an internal calibration standard was hampered by the imaging conditions and the relatively small radius of the axle. An alternate method of internal calibration was applied by using the as-irradiated compact, which had previously been inspected with a micrometer system designed and operated at INL. This produced acceptable results and may be used as a primary or secondary calibration source for future tests. However, a larger and more reproducible calibration standard will also be considered.

Leach-burn-leach analysis of the particles and matrix debris was performed using a well-tested and refined Soxhlet extraction method developed prior to the start of AGR-1 PIE. No issues were experienced with the extraction, but hot cell operator staff turnover probably contributed to a few issues with particle handling. Results of the DLBL were consistent with the presence of actinides and fission products from 20 DTF particles in each compact. There were no indications that any driver fuel particles exhibited abnormal release of actinides or fission products due to defective or failed coatings, which could have impacted the experiment if such particles were present. There was also no strong evidence of excessive diffusive release from the driver fuel particles of the radionuclides primarily studied. A high fraction of diffusive release of silver was indicated by the stable ${ }^{109} \mathrm{Ag}$ isotope, but ${ }^{110 \mathrm{~m}} \mathrm{Ag}$ had decayed too much to measure. The radial DLBL data revealed an expected concentration profile, with most of the kernel material retained in the core section and a roughly exponential drop in the concentration as a function of distance from the centerline of the compact. Compact 10-4, which had been irradiated at a higher temperature, and also subjected to post-irradiation heating to $1,400^{\circ} \mathrm{C}$, clearly retained a lower fraction of certain nuclides released by the DTF particles. Cesium release was dramatically higher in Compact 10-4, compared with Compact 1-4. Europium and strontium were also less well retained. Further detailed study in conjunction with results from other AGR-3/4 compacts subjected to radial deconsolidation, as well as analysis of the matrix and graphite rings that surrounded the compacts, will further illuminate other observations whose discussion based on just the two compacts reported herein would be premature. 


\section{REFERENCES}

Collin, Blaise P. 2015. AGR-3/4 Irradiation Experimental Plan. INL/PLN-3867, Revision 1. Idaho Falls: Idaho National Laboratory.

Collin, Blaise P. 2016. AGR-3/4 Irradiation Test Final As-Run Report. INL/EXT-15-35550, Revision 1. Idaho Falls: Idaho National Laboratory.

Croff, Allen G. 1983. "ORIGEN2: A Versatile Computer Code for Calculating the Nuclide Compositions and Characteristics of Nuclear Materials." Nucl. Tech. 62: 335-352.

Demkowicz, Paul A., John D. Hunn, David A. Petti, and Robert N. Morris. 2016. "Key results from irradiation and post-irradiation examination of AGR-1 UCO TRISO fuel." Proc. 8th International Topical Meeting on High Temperature Reactor Technology (HTR-2016). Las Vegas, November 6-10, 2016. Also published in Nucl. Eng. Des. 329: 102-109.

Demkowicz, Paul A. 2017. AGR-3/4 Phase 2 Post-Irradiation Examination Plan. INL/PLN-5382, Revision 0. Idaho Falls: Idaho National Laboratory.

Hawkes, Grant L. 2016. AGR-3/4 Daily As-Run Thermal Analyses. INL/ECAR-2807, Revision 1. Idaho Falls: Idaho National Laboratory.

Helmreich, Grant W., Fred C. Montgomery, and John D. Hunn. 2015. Development of a Radial Deconsolidation Method. ORNL/TM-2015/699, Revision 0. Oak Ridge: Oak Ridge National Laboratory.

Helmreich, Grant W., John D. Hunn, Daniel R. Brown, and Brandon J. Blamer. 2018. "New Method for Analysis of X-ray Computed Tomography Scans of TRISO Fuel Forms." Proc. 9th International Topical Meeting on High Temperature Reactor Technology (HTR-2018). Warsaw, October 8-10, 2018. Also published in Nucl. Eng. Des. 357: 110418.

Hunn, John D., and Richard A. Lowden. 2007. Data Compilation for AGR-3/4 Driver Coated Particle Composite LEU03-09T. ORNL/TM-2007/019, Revision 0. Oak Ridge: Oak Ridge National Laboratory.

Hunn, John D., Michael P. Trammell, and Fred C. Montgomery. 2011. Data Compilation for AGR-3/4 Designed-to-Fail (DTF) Fuel Compact Lot (LEU03-10T-OP2/LEU03-07DTF-OP1)-Z. ORNL/TM2011/124, Revision 0. Oak Ridge: Oak Ridge National Laboratory.

Hunn, John D., Richard A. Lowden, James H. Miller, Brian C. Jolly, Michael P. Trammell, Andrew K. Kercher, Fred C. Montgomery, and Chinthaka M. Silva. 2012. "Fabrication and Characterization of Driver Fuel Particles, Designed-to-Fail Fuel Particles, and Fuel Compacts for the US AGR-3/4 Irradiation Test." Proc. 6th International Topical Meeting on High Temperature Reactor Technology (HTR-2012). Tokyo, October 28-November 1, 2012. Also published in Nucl. Eng. Des. 271: 123130.

Hunn, John D., Robert N. Morris, Charles A. Baldwin, Fred C. Montgomery, Chinthaka M. Silva, and Tyler J. Gerczak. 2012. AGR-1 Irradiated Compact 6-1-1 PIE Report: Evaluation of As-Irradiated Fuel Performance Using Leach Burn Leach, IMGA, Materialography, and X-ray Tomography. ORNL/TM-2012/233, Revision 0. Oak Ridge: Oak Ridge National Laboratory.

Hunn, John D., Robert N. Morris, Charles A. Baldwin, Fred C. Montgomery, Chinthaka M. Silva, and Tyler J. Gerczak. 2013. AGR-1 Irradiated Compact 4-4-2 PIE Report: Evaluation of As-Irradiated Fuel Performance with Leach Burn Leach, IMGA, Materialography, and X-ray Tomography. ORNL/TM-2013/236, Revision 0. Oak Ridge: Oak Ridge National Laboratory. 
Hunn, John D., Robert N. Morris, Fred C. Montgomery, Tyler J. Gerczak, Darren J. Skitt, Charles A. Baldwin, John A. Dyer, Grant W. Helmreich, Brian D. Eckhart, Zachary M. Burns, Paul A. Demkowicz, and John D. Stempien. 2018. "Post-Irradiation Examination and Safety Testing of US AGR-2 Irradiation Test Compacts." Proc. 9th International Topical Meeting on High Temperature Reactor Technology (HTR-2018). Warsaw, October 8-10, 2018.

Hunn, John D., and Fred C. Montgomery. 2020. Data Acquisition Method: Leach-Burn-Leach Analysis of Irradiated Fuel Compacts Using a Soxhlet Extractor in the 3525 Hot Cell. AGR-CHAR-DAM-37, Revision 4. Oak Ridge: Oak Ridge National Laboratory.

Kercher, Andrew K., and John D. Hunn. 2006. Results from ORNL Characterization of Nominal $350 \mu \mathrm{m}$ LEUCO Kernels (LEU03) from the BWXT G73V-20-69303 Composite. ORNL/TM-2006/552, Revision 0. Oak Ridge: Oak Ridge National Laboratory.

Kercher, Andrew K., Brian C. Jolly, Fred C. Montgomery, Chinthaka M. Silva, and John D. Hunn. 2011. Data Compilation for AGR-3/4 Designed-to-Fail (DTF) Fuel Particle Batch LEU03-07DTF. ORNL/TM-2011/109, Revision 0. Oak Ridge: Oak Ridge National Laboratory.

Lowden, Richard A. 2006. Fabrication of Baseline and Variant Particle Fuel for AGR-1. ORNL/CF-2006/02, Revision 0. Oak Ridge: Oak Ridge National Laboratory.

Ludwig, Scott B., and Allen G. Croff. 2002. ORIGEN2.2-Isotope Generation and Depletion Code Matrix Exponential Method. Oak Ridge: Oak Ridge National Laboratory.

Petti, David A., Richard R. Hobbins, James M. Kendall, and John J. Saurwein. 2005. Technical Program Plan for the Advanced Gas Reactor Fuel Development and Qualification Program. INL/EXT-0500465, Revision 1. Idaho Falls: Idaho National Laboratory.

Stempien, John D., Francine J. Rice, Phil L. Winston, and Jason M. Harp. 2016. AGR-3/4 Irradiation Test Train Disassembly and Component Metrology First Look Report. INL/EXT-16-38005, Revision 1. Idaho Falls: Idaho National Laboratory.

Stempien, John D. 2017. Radial Deconsolidation and Leach-Burn-Leach of AGR-3/4 Compact 3-3, 12-1, and 12-3. INL/EXT-17-43182, Revision 0. Idaho Falls: Idaho National Laboratory.

Stempien, John D., Paul A. Demkowicz, Jason M. Harp, and Philip L. Watson. 2018a. AGR-3/4 Experiment Preliminary Mass Balance. INL/EXT-18-46049, Revision 0. Idaho Falls: Idaho National Laboratory.

Stempien, John D., Paul A. Demkowicz, Edward L. Reber, and Cad L. Christensen. 2018b. "Preliminary Results from the First Round of Post-Irradiation Heating Tests of Fuel Compacts from the AGR-3/4 Irradiation." Proc. 9th International Topical Meeting on High Temperature Reactor Technology (HTR-2018). Warsaw, October 8-10, 2018.

Sterbentz, James W. 2015. JMOCUP As-Run Daily Depletion Calculation for the AGR-3/4 TRISO Particle Experiment in ATR Northeast Flux Trap. ECAR-2753, Revision 1. Idaho Falls: Idaho National Laboratory.

X-5 Monte Carlo Team. 2003. MCNP_A General Monte Carlo N-Particle Transport Code. Version 5, Volume I (LA-UR-03-1987) and Volume II (LA-CP-03-0245). Los Alamos: Los Alamos National Laboratory. 


\section{APPENDIX A. DLBL DATA}

The tables in this appendix document the DLBL data for select actinides and fission products (both radionuclides and stable nuclides). Data is provided for each primary leach solution in terms of compact fraction and particle equivalents, as described in Section 2. Appendix C contains the calculated inventory data used to convert the measured values to compact fraction. Particle equivalents were calculated from the compact fraction by multiplying by an average number of particles per compact of 1918 .

In some cases, stable and radioactive isotopes of the same element were reported. The compact fraction data for ${ }^{133} \mathrm{Cs}$ and ${ }^{137} \mathrm{Cs}$ tended to agree closely, while ${ }^{134} \mathrm{Cs}$ was often lower. The ${ }^{140} \mathrm{Ce}$ compact fraction tended to track with, but somewhat exceed that of ${ }^{144} \mathrm{Ce}$, and the same was true for ${ }^{153} \mathrm{Eu}$ compared with ${ }^{154} \mathrm{Eu}$ and ${ }^{155} \mathrm{Eu}$. It is possible that ${ }^{133} \mathrm{Cs}$ and ${ }^{153} \mathrm{Eu}$ data were elevated by isobaric interferences. The stable

${ }^{109} \mathrm{Ag}$ nuclide provided some indication of silver behavior in the absence of measurable ${ }^{110 \mathrm{~m}} \mathrm{Ag}$, which had gone through too many half-lives prior to analysis. However previous comparisons have indicated a typically poor agreement between these two isotopes (Hunn et al. 2013).

Appendix Table A-1. Exposed U and Pu detected by DLBL of AGR-3/4 Compact 1-4 Segment 1

\begin{tabular}{lccccc}
\hline DLBL Step & ${ }^{235} \mathbf{U}$ & ${ }^{236} \mathbf{U}$ & ${ }^{238} \mathbf{U}$ & ${ }^{239} \mathbf{P u}$ & ${ }^{240} \mathbf{P u}$ \\
\hline \multirow{2}{*}{ Deconsolidation acid } & $2.62 \mathrm{E}-5$ & $2.87 \mathrm{E}-5$ & $3.16 \mathrm{E}-5$ & $3.00 \mathrm{E}-6$ & $7.36 \mathrm{E}-6$ \\
& $(0.050)$ & $(0.055)$ & $(0.061)$ & $(0.0057)$ & $(0.014)$ \\
Preburn leach 1 & $2.44 \mathrm{E}-6$ & $1.87 \mathrm{E}-5$ & $6.71 \mathrm{E}-5$ & $1.04 \mathrm{E}-6$ & $3.63 \mathrm{E}-6$ \\
& $(0.0047)$ & $(0.036)$ & $(0.129)$ & $(0.002)$ & $(0.007)$ \\
Preburn leach 2 & $7.70 \mathrm{E}-7$ & $5.68 \mathrm{E}-6$ & $2.08 \mathrm{E}-5$ & $9.68 \mathrm{E}-7$ & $2.82 \mathrm{E}-6$ \\
& $(0.0015)$ & $(0.011)$ & $(0.040)$ & $(0.0019)$ & $(0.0054)$ \\
Postburn matrix leach 1 & $4.54 \mathrm{E}-6$ & $3.01 \mathrm{E}-5$ & $1.05 \mathrm{E}-4$ & $2.91 \mathrm{E}-5$ & $8.50 \mathrm{E}-5$ \\
& $(0.0087)$ & $(0.058)$ & $(0.202)$ & $(0.056)$ & $(0.163)$ \\
Postburn matrix leach 2 & $1.59 \mathrm{E}-7$ & $1.18 \mathrm{E}-6$ & $4.20 \mathrm{E}-6$ & $6.59 \mathrm{E}-7$ & $1.89 \mathrm{E}-6$ \\
& $(0.0003)$ & $(0.0023)$ & $(0.0081)$ & $(0.0013)$ & $(0.0036)$ \\
Postburn particle leach 1 ${ }^{a}$ & $4.74 \mathrm{E}-4$ & $5.82 \mathrm{E}-4$ & $5.94 \mathrm{E}-4$ & $6.18 \mathrm{E}-4$ & $6.82 \mathrm{E}-4$ \\
& $(0.908)$ & $(1.116)$ & $(1.139)$ & $(1.185)$ & $(1.307)$ \\
Postburn particle leach 2 ${ }^{a}$ & $3.27 \mathrm{E}-6$ & $5.35 \mathrm{E}-6$ & $1.12 \mathrm{E}-5$ & $9.44 \mathrm{E}-6$ & $1.85 \mathrm{E}-5$ \\
& $(0.0063)$ & $(0.010)$ & $(0.021)$ & $(0.018)$ & $(0.036)$ \\
\hline \multirow{2}{*}{ Total } & $5.11 \mathrm{E}-4$ & $6.72 \mathrm{E}-4$ & $8.34 \mathrm{E}-4$ & $6.62 \mathrm{E}-4$ & $8.01 \mathrm{E}-4$ \\
& $(0.980)$ & $(1.288)$ & $(1.599)$ & $(1.270)$ & $(1.536)$ \\
\hline
\end{tabular}

Note: Values are reported as compact inventory fractions and particle equivalents (in parentheses).

${ }^{a}$ Because of the presence of an exposed kernel in the first postburn particle leach, no scaling factor was applied to account for $\sim 11 \%$ particle population withheld from postburn analysis. 
Appendix Table A-2. Exposed U and Pu detected by DLBL of AGR-3/4 Compact 1-4 Segment 2

\begin{tabular}{lccccc}
\hline DLBL Step & ${ }^{235} \mathbf{U}$ & ${ }^{236} \mathbf{U}$ & ${ }^{238} \mathbf{U}$ & ${ }^{239} \mathbf{P u}$ & ${ }^{240} \mathbf{P u}$ \\
\hline \multirow{2}{*}{ Deconsolidation acid } & $3.35 \mathrm{E}-4$ & $3.54 \mathrm{E}-4$ & $3.54 \mathrm{E}-4$ & $1.55 \mathrm{E}-5$ & $2.23 \mathrm{E}-5$ \\
& $(0.642)$ & $(0.679)$ & $(0.678)$ & $(0.030)$ & $(0.043)$ \\
Preburn leach 1 & $6.12 \mathrm{E}-7$ & $3.19 \mathrm{E}-6$ & $1.12 \mathrm{E}-5$ & $2.38 \mathrm{E}-6$ & $6.59 \mathrm{E}-6$ \\
& $(0.0012)$ & $(0.0061)$ & $(0.021)$ & $(0.0046)$ & $(0.013)$ \\
Preburn leach 2 & $6.13 \mathrm{E}-7$ & $4.40 \mathrm{E}-6$ & $1.63 \mathrm{E}-5$ & $<6.7 \mathrm{E}-7$ & $<3.3 \mathrm{E}-6$ \\
& $(0.0012)$ & $(0.0084)$ & $(0.031)$ & $<(0.0013)$ & $<(0.0063)$ \\
Postburn matrix leach 1 & $7.73 \mathrm{E}-6$ & $4.73 \mathrm{E}-5$ & $1.67 \mathrm{E}-4$ & $5.69 \mathrm{E}-5$ & $1.76 \mathrm{E}-4$ \\
& $(0.015)$ & $(0.091)$ & $(0.321)$ & $(0.109)$ & $(0.338)$ \\
Postburn matrix leach 2 & $4.28 \mathrm{E}-7$ & $2.51 \mathrm{E}-6$ & $8.80 \mathrm{E}-6$ & $3.72 \mathrm{E}-6$ & $1.10 \mathrm{E}-5$ \\
& $(0.0008)$ & $(0.0048)$ & $(0.017)$ & $(0.0071)$ & $(0.021)$ \\
Postburn particle leach 1 ${ }^{a}$ & $4.28 \mathrm{E}-6$ & $4.09 \mathrm{E}-5$ & $1.22 \mathrm{E}-4$ & $5.33 \mathrm{E}-5$ & $1.41 \mathrm{E}-4$ \\
& $(0.0082)$ & $(0.078)$ & $(0.234)$ & $(0.102)$ & $(0.271)$ \\
Postburn particle leach ${ }^{a}{ }^{a}$ & $1.98 \mathrm{E}-7$ & $1.06 \mathrm{E}-6$ & $3.63 \mathrm{E}-6$ & $2.57 \mathrm{E}-6$ & $6.87 \mathrm{E}-6$ \\
& $(0.0004)$ & $(0.002)$ & $(0.007)$ & $(0.0049)$ & $(0.013)$ \\
\hline \multirow{2}{*}{ Total } & $3.48 \mathrm{E}-4$ & $4.53 \mathrm{E}-4$ & $6.83 \mathrm{E}-4$ & $1.34 \mathrm{E}-4$ & $3.64 \mathrm{E}-4$ \\
& $(0.668)$ & $(0.870)$ & $(1.310)$ & $(0.258)$ & $(0.699)$
\end{tabular}

Note: Values are reported as compact inventory fractions and particle equivalents (in parentheses).

${ }^{a}$ Postburn particle leach data were scaled to account for $\sim 14 \%$ particle population withheld from postburn analysis.

Appendix Table A-3. Exposed U and Pu detected by DLBL of AGR-3/4 Compact 1-4 Segment 3

\begin{tabular}{|c|c|c|c|c|c|}
\hline DLBL Step & ${ }^{235} \mathbf{U}$ & ${ }^{236} \mathbf{U}$ & ${ }^{238} \mathbf{U}$ & ${ }^{239} \mathbf{P u}$ & ${ }^{240} \mathrm{Pu}$ \\
\hline Deconsolidation acid & $\begin{array}{c}6.61 \mathrm{E}-4 \\
(1.268)\end{array}$ & $\begin{array}{c}6.98 \mathrm{E}-4 \\
(1.339)\end{array}$ & $\begin{array}{c}7.04 \mathrm{E}-4 \\
(1.350)\end{array}$ & $\begin{array}{c}1.86 \mathrm{E}-4 \\
(0.357)\end{array}$ & $\begin{array}{c}1.85 \mathrm{E}-4 \\
(0.355)\end{array}$ \\
\hline Preburn leach 1 & $\begin{array}{c}1.16 \mathrm{E}-6 \\
(0.0022)\end{array}$ & $\begin{array}{c}6.78 \mathrm{E}-6 \\
(0.013)\end{array}$ & $\begin{array}{c}2.44 \mathrm{E}-5 \\
(0.047)\end{array}$ & $\begin{array}{c}4.71 \mathrm{E}-6 \\
(0.009)\end{array}$ & $\begin{array}{l}1.13 \mathrm{E}-5 \\
(0.022)\end{array}$ \\
\hline Preburn leach 2 & $\begin{array}{l}2.46 \mathrm{E}-6 \\
(0.0047)\end{array}$ & $\begin{array}{c}1.55 \mathrm{E}-5 \\
(0.030)\end{array}$ & $\begin{array}{c}5.84 \mathrm{E}-5 \\
(0.112)\end{array}$ & $\begin{array}{c}1.27 \mathrm{E}-5 \\
(0.024)\end{array}$ & $\begin{array}{c}3.70 \mathrm{E}-5 \\
(0.071)\end{array}$ \\
\hline Postburn matrix leach 1 & $\begin{array}{l}4.83 \mathrm{E}-6 \\
(0.0093)\end{array}$ & $\begin{array}{c}2.13 \mathrm{E}-5 \\
(0.041)\end{array}$ & $\begin{array}{c}7.64 \mathrm{E}-5 \\
(0.146)\end{array}$ & $\begin{array}{c}2.27 \mathrm{E}-5 \\
(0.043)\end{array}$ & $\begin{array}{c}6.58 \mathrm{E}-5 \\
(0.126)\end{array}$ \\
\hline Postburn matrix leach 2 & $\begin{array}{c}5.29 \mathrm{E}-7 \\
(0.001)\end{array}$ & $\begin{array}{c}1.91 \mathrm{E}-6 \\
(0.0037)\end{array}$ & $\begin{array}{c}7.44 \mathrm{E}-6 \\
(0.014)\end{array}$ & $\begin{array}{l}3.33 \mathrm{E}-6 \\
(0.0064)\end{array}$ & $\begin{array}{c}8.47 \mathrm{E}-6 \\
(0.016)\end{array}$ \\
\hline Postburn particle leach $1^{a}$ & $\begin{array}{l}2.21 \mathrm{E}-6 \\
(0.0042)\end{array}$ & $\begin{array}{l}1.30 \mathrm{E}-5 \\
(0.025)\end{array}$ & $\begin{array}{c}3.89 \mathrm{E}-5 \\
(0.075)\end{array}$ & $\begin{array}{c}1.91 \mathrm{E}-5 \\
(0.037)\end{array}$ & $\begin{array}{c}5.37 \mathrm{E}-5 \\
(0.103)\end{array}$ \\
\hline Postburn particle leach $2^{a}$ & $\begin{array}{l}5.73 \mathrm{E}-7 \\
(0.0011)\end{array}$ & $\begin{array}{c}7.06 \mathrm{E}-6 \\
(0.014)\end{array}$ & $\begin{array}{c}2.03 \mathrm{E}-5 \\
(0.039)\end{array}$ & $\begin{array}{c}1.22 \mathrm{E}-5 \\
(0.023)\end{array}$ & $\begin{array}{c}3.39 \mathrm{E}-5 \\
(0.065)\end{array}$ \\
\hline Total & $\begin{array}{c}6.73 \mathrm{E}-4 \\
(1.291)\end{array}$ & $\begin{array}{l}7.64 \mathrm{E}-4 \\
(1.465)\end{array}$ & $\begin{array}{c}9.29 \mathrm{E}-4 \\
(1.783)\end{array}$ & $\begin{array}{c}2.61 \mathrm{E}-4 \\
(0.501)\end{array}$ & $\begin{array}{c}3.95 \mathrm{E}-4 \\
(0.758)\end{array}$ \\
\hline
\end{tabular}

Note: Values are reported as compact inventory fractions and particle equivalents (in parentheses).

${ }^{a}$ Because most of the particles deconsolidated from Segment 3 were lost when sieve stack was knocked over, only $\sim 2 \%$ of the particles were included in postburn particle leach and data were not scaled. 
Appendix Table A-4. Exposed U and Pu detected by DLBL of AGR-3/4 Compact 1-4 Segment 4

\begin{tabular}{|c|c|c|c|c|c|}
\hline DLBL Step & ${ }^{235} \mathbf{U}$ & ${ }^{236} \mathbf{U}$ & ${ }^{238} \mathbf{U}$ & ${ }^{239} \mathrm{Pu}$ & ${ }^{240} \mathrm{Pu}$ \\
\hline Deconsolidation acid & $\begin{array}{c}9.30 \mathrm{E}-3 \\
(17.831)\end{array}$ & $\begin{array}{l}9.44 \mathrm{E}-3 \\
(18.104)\end{array}$ & $\begin{array}{l}9.22 \mathrm{E}-3 \\
(17.684)\end{array}$ & $\begin{array}{l}8.86 \mathrm{E}-3 \\
(16.995)\end{array}$ & $\begin{array}{l}8.35 \mathrm{E}-3 \\
(16.023)\end{array}$ \\
\hline Preburn leach 1 & $\begin{array}{c}5.55 \mathrm{E}-5 \\
(0.106)\end{array}$ & $\begin{array}{c}5.82 \mathrm{E}-5 \\
(0.112)\end{array}$ & $\begin{array}{c}6.10 \mathrm{E}-5 \\
(0.117)\end{array}$ & $\begin{array}{c}1.57 \mathrm{E}-4 \\
(0.300)\end{array}$ & $\begin{array}{c}1.51 \mathrm{E}-4 \\
(0.290)\end{array}$ \\
\hline Preburn leach 2 & $\begin{array}{l}1.48 \mathrm{E}-5 \\
(0.028)\end{array}$ & $\begin{array}{l}1.70 \mathrm{E}-5 \\
(0.033)\end{array}$ & $\begin{array}{c}2.04 \mathrm{E}-5 \\
(0.039)\end{array}$ & $\begin{array}{c}3.12 \mathrm{E}-5 \\
(0.060)\end{array}$ & $\begin{array}{c}3.59 \mathrm{E}-5 \\
(0.069)\end{array}$ \\
\hline Postburn matrix leach 1 & $\begin{array}{c}2.49 \mathrm{E}-5 \\
(0.048)\end{array}$ & $\begin{array}{c}3.95 \mathrm{E}-5 \\
(0.076)\end{array}$ & $\begin{array}{c}8.17 \mathrm{E}-5 \\
(0.157)\end{array}$ & $\begin{array}{c}5.86 \mathrm{E}-5 \\
(0.112)\end{array}$ & $\begin{array}{c}8.81 \mathrm{E}-5 \\
(0.169)\end{array}$ \\
\hline Postburn matrix leach 2 & $\begin{array}{l}6.29 \mathrm{E}-7 \\
(0.0012)\end{array}$ & $\begin{array}{c}1.05 \mathrm{E}-6 \\
(0.002)\end{array}$ & $\begin{array}{l}2.50 \mathrm{E}-6 \\
(0.0048)\end{array}$ & $\begin{array}{c}2.09 \mathrm{E}-6 \\
(0.004)\end{array}$ & $\begin{array}{l}3.89 \mathrm{E}-6 \\
(0.0075)\end{array}$ \\
\hline Postburn particle leach $1^{a}$ & $\begin{array}{c}2.39 \mathrm{E}-5 \\
(0.046)\end{array}$ & $\begin{array}{c}3.09 \mathrm{E}-5 \\
(0.059)\end{array}$ & $\begin{array}{c}4.67 \mathrm{E}-5 \\
(0.090)\end{array}$ & $\begin{array}{c}1.99 \mathrm{E}-4 \\
(0.381)\end{array}$ & $\begin{array}{c}2.30 \mathrm{E}-4 \\
(0.441)\end{array}$ \\
\hline Postburn particle leach $2^{a}$ & $\begin{array}{c}6.60 \mathrm{E}-7 \\
(0.0013)\end{array}$ & $\begin{array}{l}3.23 \mathrm{E}-6 \\
(0.0062)\end{array}$ & $\begin{array}{c}1.03 \mathrm{E}-5 \\
(0.020)\end{array}$ & $\begin{array}{c}7.34 \mathrm{E}-6 \\
(0.014)\end{array}$ & $\begin{array}{c}1.77 \mathrm{E}-5 \\
(0.034)\end{array}$ \\
\hline Total & $\begin{array}{l}9.42 \mathrm{E}-3 \\
(18.062)\end{array}$ & $\begin{array}{l}9.59 \mathrm{E}-3 \\
(18.391)\end{array}$ & $\begin{array}{l}9.44 \mathrm{E}-3 \\
(18.111)\end{array}$ & $\begin{array}{l}9.32 \mathrm{E}-3 \\
(17.866)\end{array}$ & $\begin{array}{l}8.88 \mathrm{E}-3 \\
(17.034)\end{array}$ \\
\hline
\end{tabular}

Note: Values are reported as compact inventory fractions and particle equivalents (in parentheses).

${ }^{a}$ Postburn particle leach data were scaled to account for $\sim 15 \%$ particle population withheld from postburn analysis.

Appendix Table A-5. Exposed U and Pu detected by DLBL of AGR-3/4 Compact 10-4 Segment 1

\begin{tabular}{lccccc}
\hline DLBL Step & ${ }^{235} \mathbf{U}$ & ${ }^{236} \mathbf{U}$ & ${ }^{238} \mathbf{U}$ & ${ }^{239} \mathbf{P u}$ & ${ }^{\mathbf{2 4 0}} \mathbf{P u}$ \\
\hline \multirow{2}{*}{ Deconsolidation acid } & $9.78 \mathrm{E}-5$ & $9.77 \mathrm{E}-5$ & $1.13 \mathrm{E}-4$ & $4.98 \mathrm{E}-5$ & $4.88 \mathrm{E}-5$ \\
& $(0.188)$ & $(0.187)$ & $(0.217)$ & $(0.095)$ & $(0.094)$ \\
Preburn leach 1 & $6.64 \mathrm{E}-7$ & $9.87 \mathrm{E}-7$ & $4.14 \mathrm{E}-6$ & $3.56 \mathrm{E}-6$ & $5.20 \mathrm{E}-6$ \\
& $(0.0013)$ & $(0.0019)$ & $(0.0079)$ & $(0.0068)$ & $(0.010)$ \\
Preburn leach 2 & $4.83 \mathrm{E}-7$ & $5.57 \mathrm{E}-7$ & $2.23 \mathrm{E}-6$ & $1.65 \mathrm{E}-6$ & $2.84 \mathrm{E}-6$ \\
& $(0.0009)$ & $(0.0011)$ & $(0.0043)$ & $(0.0032)$ & $(0.0055)$ \\
Postburn matrix leach 1 & $9.61 \mathrm{E}-6$ & $1.43 \mathrm{E}-5$ & $6.84 \mathrm{E}-5$ & $3.09 \mathrm{E}-5$ & $5.48 \mathrm{E}-5$ \\
& $(0.018)$ & $(0.027)$ & $(0.131)$ & $(0.059)$ & $(0.105)$ \\
Postburn matrix leach 2 & $4.43 \mathrm{E}-7$ & $7.78 \mathrm{E}-7$ & $3.69 \mathrm{E}-6$ & $2.00 \mathrm{E}-6$ & $3.47 \mathrm{E}-6$ \\
& $(0.0008)$ & $(0.0015)$ & $(0.0071)$ & $(0.0038)$ & $(0.0067)$ \\
Postburn particle leach 1 ${ }^{a}$ & $1.16 \mathrm{E}-5$ & $3.21 \mathrm{E}-5$ & $1.12 \mathrm{E}-4$ & $5.78 \mathrm{E}-5$ & $1.01 \mathrm{E}-4$ \\
& $(0.022)$ & $(0.062)$ & $(0.215)$ & $(0.111)$ & $(0.194)$ \\
Postburn particle leach ${ }^{a}{ }^{a}$ & $1.61 \mathrm{E}-6$ & $3.91 \mathrm{E}-6$ & $1.74 \mathrm{E}-5$ & $9.77 \mathrm{E}-6$ & $1.63 \mathrm{E}-5$ \\
& $(0.0031)$ & $(0.0075)$ & $(0.033)$ & $(0.019)$ & $(0.031)$ \\
\hline \multirow{2}{*}{ Total } & $1.22 \mathrm{E}-4$ & $1.50 \mathrm{E}-4$ & $3.21 \mathrm{E}-4$ & $1.55 \mathrm{E}-4$ & $2.33 \mathrm{E}-4$ \\
& $(0.234)$ & $(0.288)$ & $(0.615)$ & $(0.298)$ & $(0.446)$
\end{tabular}

Note: Values are reported as compact inventory fractions and particle equivalents (in parentheses).

${ }^{a}$ Postburn particle leach data were scaled to account for $\sim 8 \%$ particle population withheld from postburn analysis. 
Appendix Table A-6. Exposed U and Pu detected by DLBL of AGR-3/4 Compact 10-4 Segment 2

\begin{tabular}{lccccc}
\hline DLBL Step & ${ }^{235} \mathbf{U}$ & ${ }^{236} \mathbf{U}$ & ${ }^{238} \mathbf{U}$ & ${ }^{239} \mathbf{P u}$ & ${ }^{240} \mathbf{P u}$ \\
\hline \multirow{2}{*}{ Deconsolidation acid } & $4.33 \mathrm{E}-4$ & $4.11 \mathrm{E}-4$ & $4.14 \mathrm{E}-4$ & $2.07 \mathrm{E}-4$ & $1.98 \mathrm{E}-4$ \\
& $(0.830)$ & $(0.789)$ & $(0.794)$ & $(0.396)$ & $(0.381)$ \\
Preburn leach 1 & $8.33 \mathrm{E}-6$ & $9.91 \mathrm{E}-6$ & $2.01 \mathrm{E}-5$ & $9.64 \mathrm{E}-6$ & $1.38 \mathrm{E}-5$ \\
& $(0.016)$ & $(0.019)$ & $(0.039)$ & $(0.018)$ & $(0.026)$ \\
Preburn leach 2 & $2.87 \mathrm{E}-6$ & $1.36 \mathrm{E}-6$ & $6.52 \mathrm{E}-6$ & $3.57 \mathrm{E}-6$ & $5.89 \mathrm{E}-6$ \\
& $(0.0055)$ & $(0.0026)$ & $(0.012)$ & $(0.0069)$ & $(0.011)$ \\
Postburn matrix leach 1 & $4.31 \mathrm{E}-6$ & $1.11 \mathrm{E}-5$ & $5.09 \mathrm{E}-5$ & $2.81 \mathrm{E}-5$ & $4.84 \mathrm{E}-5$ \\
& $(0.0083)$ & $(0.021)$ & $(0.098)$ & $(0.054)$ & $(0.093)$ \\
Postburn matrix leach 2 & $1.08 \mathrm{E}-6$ & $2.68 \mathrm{E}-6$ & $1.07 \mathrm{E}-5$ & $4.98 \mathrm{E}-6$ & $7.77 \mathrm{E}-6$ \\
& $(0.0021)$ & $(0.0051)$ & $(0.021)$ & $(0.0096)$ & $(0.015)$ \\
Postburn particle leach 1 ${ }^{a}$ & $1.09 \mathrm{E}-5$ & $3.46 \mathrm{E}-5$ & $1.26 \mathrm{E}-4$ & $6.75 \mathrm{E}-5$ & $1.15 \mathrm{E}-4$ \\
& $(0.021)$ & $(0.066)$ & $(0.242)$ & $(0.129)$ & $(0.220)$ \\
Postburn particle leach ${ }^{a}{ }^{a}$ & $1.07 \mathrm{E}-6$ & $4.88 \mathrm{E}-6$ & $2.09 \mathrm{E}-5$ & $7.97 \mathrm{E}-6$ & $1.44 \mathrm{E}-5$ \\
& $(0.0021)$ & $(0.0094)$ & $(0.040)$ & $(0.015)$ & $(0.028)$ \\
\hline \multirow{2}{*}{ Total } & $4.61 \mathrm{E}-4$ & $4.76 \mathrm{E}-4$ & $6.49 \mathrm{E}-4$ & $3.28 \mathrm{E}-4$ & $4.03 \mathrm{E}-4$ \\
& $(0.885)$ & $(0.913)$ & $(1.246)$ & $(0.630)$ & $(0.774)$
\end{tabular}

Note: Values are reported as compact inventory fractions and particle equivalents (in parentheses).

${ }^{a}$ Postburn particle leach data were scaled to account for $\sim 10 \%$ particle population withheld from postburn analysis.

Appendix Table A-7. Exposed U and Pu detected by DLBL of AGR-3/4 Compact 10-4 Segment 3

\begin{tabular}{lccccc}
\hline DLBL Step & ${ }^{235} \mathbf{U}$ & ${ }^{\mathbf{2 3 6}} \mathbf{U}$ & ${ }^{\mathbf{2 3 8}} \mathbf{U}$ & ${ }^{\mathbf{2 3 9}} \mathbf{P u}$ & ${ }^{\mathbf{2 4 0}} \mathbf{P u}$ \\
\hline \multirow{2}{*}{ Deconsolidation acid } & $1.01 \mathrm{E}-2$ & $9.45 \mathrm{E}-3$ & $9.47 \mathrm{E}-3$ & $7.20 \mathrm{E}-3$ & $7.09 \mathrm{E}-3$ \\
& $(19.416)$ & $(18.116)$ & $(18.158)$ & $(13.806)$ & $(13.593)$ \\
Preburn leach 1 & $1.79 \mathrm{E}-4$ & $1.75 \mathrm{E}-4$ & $1.94 \mathrm{E}-4$ & $3.20 \mathrm{E}-4$ & $3.84 \mathrm{E}-4$ \\
& $(0.342)$ & $(0.335)$ & $(0.372)$ & $(0.614)$ & $(0.737)$ \\
Preburn leach 2 & $6.07 \mathrm{E}-6$ & $6.64 \mathrm{E}-6$ & $1.14 \mathrm{E}-5$ & $3.12 \mathrm{E}-5$ & $3.97 \mathrm{E}-6$ \\
& $(0.012)$ & $(0.013)$ & $(0.022)$ & $(0.060)$ & $(0.0076)$ \\
Postburn matrix leach 1 & $2.61 \mathrm{E}-5$ & $1.37 \mathrm{E}-4$ & $5.94 \mathrm{E}-4$ & $3.93 \mathrm{E}-4$ & $6.18 \mathrm{E}-4$ \\
& $(0.050)$ & $(0.263)$ & $(1.139)$ & $(0.753)$ & $(1.186)$ \\
Postburn matrix leach 2 & $9.89 \mathrm{E}-7$ & $4.70 \mathrm{E}-6$ & $2.17 \mathrm{E}-5$ & $1.21 \mathrm{E}-5$ & $2.01 \mathrm{E}-5$ \\
& $(0.0019)$ & $(0.009)$ & $(0.042)$ & $(0.023)$ & $(0.039)$ \\
Postburn particle leach 1 ${ }^{a}$ & $2.21 \mathrm{E}-5$ & $3.07 \mathrm{E}-5$ & $7.41 \mathrm{E}-5$ & $6.57 \mathrm{E}-4$ & $8.58 \mathrm{E}-4$ \\
& $(0.042)$ & $(0.059)$ & $(0.142)$ & $(1.259)$ & $(1.646)$ \\
Postburn particle leach ${ }^{a}{ }^{a}$ & $7.08 \mathrm{E}-6$ & $4.41 \mathrm{E}-5$ & $1.84 \mathrm{E}-4$ & $7.18 \mathrm{E}-5$ & $1.39 \mathrm{E}-4$ \\
& $(0.014)$ & $(0.085)$ & $(0.354)$ & $(0.138)$ & $(0.267)$ \\
\hline \multirow{2}{*}{ Total } & $1.04 \mathrm{E}-2$ & $9.84 \mathrm{E}-3$ & $1.05 \mathrm{E}-2$ & $8.68 \mathrm{E}-3$ & $9.11 \mathrm{E}-3$ \\
& $(19.878)$ & $(18.879)$ & $(20.227)$ & $(16.653)$ & $(17.476)$ \\
\hline
\end{tabular}

Note: Values are reported as compact inventory fractions and particle equivalents (in parentheses).

${ }^{a}$ Postburn particle leach data were scaled to account for $\sim 7 \%$ particle population withheld from postburn analysis. 
Appendix Table A-8. Typically tracked beta/gamma-emitting fission products detected by DLBL of AGR-3/4 Compact 1-4 Segment 1

\begin{tabular}{|c|c|c|c|c|c|c|c|c|c|}
\hline DLBL Step & ${ }^{90} \mathrm{Sr}$ & ${ }^{106} \mathbf{R u}$ & ${ }^{110 m} \mathrm{Ag}$ & ${ }^{125} \mathrm{Sb}$ & ${ }^{134} \mathrm{Cs}$ & ${ }^{137} \mathrm{Cs}$ & ${ }^{144} \mathrm{Ce}$ & ${ }^{154} \mathbf{E u}$ & ${ }^{155} \mathbf{E u}$ \\
\hline Deconsolidation acid & $\begin{array}{c}3.15 \mathrm{E}-5 \\
(0.060)\end{array}$ & $\begin{array}{l}<3.7 \mathrm{E}-5 \\
<(0.071)\end{array}$ & $\begin{array}{c}<1.2 \mathrm{E}-2 \\
<(23.973)\end{array}$ & $\begin{array}{l}<4.7 \mathrm{E}-5 \\
<(0.090)\end{array}$ & $\begin{array}{l}1.30 \mathrm{E}-4 \\
(0.249)\end{array}$ & $\begin{array}{l}1.76 \mathrm{E}-4 \\
(0.337)\end{array}$ & $\begin{array}{c}3.89 \mathrm{E}-5 \\
(0.075)\end{array}$ & $\begin{array}{c}4.09 \mathrm{E}-5 \\
(0.079)\end{array}$ & $\begin{array}{c}4.95 \mathrm{E}-5 \\
(0.095)\end{array}$ \\
\hline Preburn leach 1 & $\begin{array}{l}1.05 \mathrm{E}-6 \\
(0.002)\end{array}$ & $\begin{array}{c}7.41 \mathrm{E}-6 \\
(0.014)\end{array}$ & $\begin{array}{c}<7.2 \mathrm{E}-3 \\
<(13.771)\end{array}$ & $\begin{array}{l}1.66 \mathrm{E}-5 \\
(0.032)\end{array}$ & $\begin{array}{l}2.71 \mathrm{E}-6 \\
(0.0052)\end{array}$ & $\begin{array}{l}5.11 \mathrm{E}-6 \\
(0.0098)\end{array}$ & $\begin{array}{c}<2.1 \mathrm{E}-6 \\
<(0.0041)\end{array}$ & $\begin{array}{l}<1.4 \mathrm{E}-5 \\
<(0.026)\end{array}$ & $\begin{array}{l}<8.4 \mathrm{E}-6 \\
<(0.016)\end{array}$ \\
\hline Preburn leach 2 & $\begin{array}{l}4.53 \mathrm{E}-7 \\
(0.0009)\end{array}$ & $\begin{array}{l}1.78 \mathrm{E}-5 \\
(0.034)\end{array}$ & $\begin{array}{c}<1.1 \mathrm{E}-2 \\
<(20.637)\end{array}$ & $\begin{array}{l}<1.2 \mathrm{E}-5 \\
<(0.023)\end{array}$ & $\begin{array}{c}1.19 \mathrm{E}-6 \\
(0.0023)\end{array}$ & $\begin{array}{l}1.52 \mathrm{E}-6 \\
(0.0029)\end{array}$ & $\begin{array}{l}<3.1 \mathrm{E}-6 \\
<(0.006)\end{array}$ & $\begin{array}{c}6.35 \mathrm{E}-5 \\
(0.122)\end{array}$ & $\begin{array}{l}<1.6 \mathrm{E}-5 \\
<(0.031)\end{array}$ \\
\hline Postburn matrix leach 1 & $\begin{array}{c}4.36 \mathrm{E}-5 \\
(0.084)\end{array}$ & $\begin{array}{l}3.43 \mathrm{E}-6 \\
(0.0066)\end{array}$ & $\begin{array}{l}<4.7 \mathrm{E}-3 \\
<(8.952)\end{array}$ & $\begin{array}{l}<9.6 \mathrm{E}-6 \\
<(0.018)\end{array}$ & $\begin{array}{c}1.02 \mathrm{E}-5 \\
(0.020)\end{array}$ & $\begin{array}{c}2.10 \mathrm{E}-5 \\
(0.040)\end{array}$ & $\begin{array}{c}3.34 \mathrm{E}-6 \\
(0.0064)\end{array}$ & $\begin{array}{c}9.84 \mathrm{E}-5 \\
(0.189)\end{array}$ & $\begin{array}{c}5.28 \mathrm{E}-5 \\
(0.101)\end{array}$ \\
\hline Postburn matrix leach 2 & $\begin{array}{l}6.17 \mathrm{E}-7 \\
(0.0012)\end{array}$ & $\begin{array}{c}<4.3 \mathrm{E}-6 \\
<(0.0083)\end{array}$ & $\begin{array}{l}<2.8 \mathrm{E}-3 \\
<(5.346)\end{array}$ & $\begin{array}{c}<4.0 \mathrm{E}-6 \\
<(0.0077)\end{array}$ & $\begin{array}{l}7.37 \mathrm{E}-7 \\
(0.0014)\end{array}$ & $\begin{array}{c}1.62 \mathrm{E}-6 \\
(0.0031)\end{array}$ & $\begin{array}{c}<8.6 \mathrm{E}-7 \\
<(0.0017)\end{array}$ & $\begin{array}{c}<5.1 \mathrm{E}-6 \\
<(0.0098)\end{array}$ & $\begin{array}{c}<3.4 \mathrm{E}-6 \\
<(0.0066)\end{array}$ \\
\hline Postburn particle leach $1^{a}$ & $\begin{array}{l}6.18 \mathrm{E}-4 \\
(1.185)\end{array}$ & $\begin{array}{l}<7.6 \mathrm{E}-5 \\
<(0.147)\end{array}$ & $\begin{array}{c}<3.0 \mathrm{E}-2 \\
<(56.658)\end{array}$ & $\begin{array}{c}3.20 \mathrm{E}-4 \\
(0.615)\end{array}$ & $\begin{array}{c}3.02 \mathrm{E}-4 \\
(0.580)\end{array}$ & $\begin{array}{c}4.29 \mathrm{E}-4 \\
(0.824)\end{array}$ & $\begin{array}{c}5.60 \mathrm{E}-4 \\
(1.073)\end{array}$ & $\begin{array}{c}5.31 \mathrm{E}-4 \\
(1.019)\end{array}$ & $\begin{array}{c}5.57 \mathrm{E}-4 \\
(1.068)\end{array}$ \\
\hline Postburn particle leach $2^{a}$ & $\begin{array}{c}6.53 \mathrm{E}-6 \\
(0.013)\end{array}$ & $\begin{array}{l}<1.9 \mathrm{E}-5 \\
<(0.036)\end{array}$ & $\begin{array}{c}<1.0 \mathrm{E}-2 \\
<(19.822)\end{array}$ & $\begin{array}{l}<1.7 \mathrm{E}-5 \\
<(0.033)\end{array}$ & $\begin{array}{c}8.69 \mathrm{E}-6 \\
(0.017)\end{array}$ & $\begin{array}{l}1.45 \mathrm{E}-5 \\
(0.028)\end{array}$ & $\begin{array}{c}<4.2 \mathrm{E}-6 \\
<(0.0081)\end{array}$ & $\begin{array}{l}<7.6 \mathrm{E}-6 \\
<(0.015)\end{array}$ & $\begin{array}{l}<1.3 \mathrm{E}-4 \\
<(0.240)\end{array}$ \\
\hline Total & $\begin{array}{l}7.02 \mathrm{E}-4 \\
(1.346)\end{array}$ & $\begin{array}{c}2.86 \mathrm{E}-5 \\
(0.055)\end{array}$ & $\begin{array}{c}0.00 \mathrm{E}+0 \\
(0.000)\end{array}$ & $\begin{array}{c}3.37 \mathrm{E}-4 \\
(0.646)\end{array}$ & $\begin{array}{c}4.56 \mathrm{E}-4 \\
(0.874)\end{array}$ & $\begin{array}{c}6.49 \mathrm{E}-4 \\
(1.244)\end{array}$ & $\begin{array}{c}6.02 \mathrm{E}-4 \\
(1.154)\end{array}$ & $\begin{array}{l}7.34 \mathrm{E}-4 \\
(1.408)\end{array}$ & $\begin{array}{c}6.59 \mathrm{E}-4 \\
(1.264)\end{array}$ \\
\hline
\end{tabular}

Note: Chemical separation and beta analysis were used to measure ${ }^{90} \mathrm{Sr}$; other nuclides were measured by gamma spectrometry.

Note: Values are reported as compact inventory fractions and particle equivalents (in parentheses).

Note: A less-than value indicates that the concentration in the leachate was below the minimum detectable limit; these values are not included in the totals.

${ }^{a}$ Because of the presence of an exposed kernel in the first postburn particle leach, no scaling factor was applied to account for $\sim 11 \%$ particle population

withheld from postburn analysis. 
Appendix Table A-9. Typically tracked beta/gamma-emitting fission products detected by DLBL of AGR-3/4 Compact 1-4 Segment 2

\begin{tabular}{|c|c|c|c|c|c|c|c|c|c|}
\hline DLBL Step & ${ }^{90} \mathrm{Sr}$ & ${ }^{106} \mathrm{Ru}$ & ${ }^{110 m} \mathrm{Ag}$ & ${ }^{125} \mathrm{Sb}$ & ${ }^{134} \mathrm{Cs}$ & ${ }^{137} \mathrm{Cs}$ & ${ }^{144} \mathrm{Ce}$ & ${ }^{154} \mathbf{E u}$ & ${ }^{155} \mathbf{E u}$ \\
\hline Deconsolidation acid & $\begin{array}{c}2.73 \mathrm{E}-4 \\
(0.523)\end{array}$ & $\begin{array}{c}9.26 \mathrm{E}-5 \\
(0.178)\end{array}$ & $\begin{array}{c}<2.0 \mathrm{E}-2 \\
<(38.245)\end{array}$ & $\begin{array}{l}<8.3 \mathrm{E}-5 \\
<(0.159)\end{array}$ & $\begin{array}{c}5.00 \mathrm{E}-4 \\
(0.959)\end{array}$ & $\begin{array}{c}6.70 \mathrm{E}-4 \\
(1.285)\end{array}$ & $\begin{array}{c}3.41 \mathrm{E}-4 \\
(0.655)\end{array}$ & $\begin{array}{c}2.77 \mathrm{E}-4 \\
(0.531)\end{array}$ & $\begin{array}{c}3.50 \mathrm{E}-4 \\
(0.672)\end{array}$ \\
\hline Preburn leach 1 & $\begin{array}{c}1.73 \mathrm{E}-6 \\
(0.0033)\end{array}$ & $\begin{array}{l}<8.8 \mathrm{E}-6 \\
<(0.017)\end{array}$ & $\begin{array}{l}<5.6 \mathrm{E}-3 \\
<(10.647)\end{array}$ & $\begin{array}{c}1.80 \mathrm{E}-5 \\
(0.035)\end{array}$ & $\begin{array}{c}1.24 \mathrm{E}-6 \\
(0.0024)\end{array}$ & $\begin{array}{l}2.74 \mathrm{E}-6 \\
(0.0053)\end{array}$ & $\begin{array}{c}<1.6 \mathrm{E}-6 \\
<(0.0031)\end{array}$ & $\begin{array}{l}<1.2 \mathrm{E}-5 \\
<(0.023)\end{array}$ & $\begin{array}{l}<6.7 \mathrm{E}-6 \\
<(0.013)\end{array}$ \\
\hline Preburn leach 2 & $\begin{array}{l}5.98 \mathrm{E}-7 \\
(0.0011)\end{array}$ & $\begin{array}{l}<1.7 \mathrm{E}-5 \\
<(0.032)\end{array}$ & $\begin{array}{c}<1.1 \mathrm{E}-2 \\
<(20.893)\end{array}$ & $\begin{array}{l}<1.3 \mathrm{E}-5 \\
<(0.026)\end{array}$ & $\begin{array}{c}<1.3 \mathrm{E}-6 \\
<(0.0024)\end{array}$ & $\begin{array}{c}1.06 \mathrm{E}-6 \\
(0.002)\end{array}$ & $\begin{array}{l}<3.7 \mathrm{E}-6 \\
<(0.007)\end{array}$ & $\begin{array}{l}<2.0 \mathrm{E}-5 \\
<(0.039)\end{array}$ & $\begin{array}{l}<1.8 \mathrm{E}-5 \\
<(0.035)\end{array}$ \\
\hline Postburn matrix leach 1 & $\begin{array}{c}4.30 \mathrm{E}-5 \\
(0.083)\end{array}$ & $\begin{array}{c}1.75 \mathrm{E}-5 \\
(0.034)\end{array}$ & $\begin{array}{c}<1.1 \mathrm{E}-2 \\
<(20.535)\end{array}$ & $\begin{array}{l}<2.0 \mathrm{E}-5 \\
<(0.039)\end{array}$ & $\begin{array}{c}7.95 \mathrm{E}-6 \\
(0.015)\end{array}$ & $\begin{array}{c}2.98 \mathrm{E}-5 \\
(0.057)\end{array}$ & $\begin{array}{l}3.48 \mathrm{E}-6 \\
(0.0067)\end{array}$ & $\begin{array}{c}1.26 \mathrm{E}-4 \\
(0.241)\end{array}$ & $\begin{array}{c}7.45 \mathrm{E}-5 \\
(0.143)\end{array}$ \\
\hline Postburn matrix leach 2 & $\begin{array}{l}2.80 \mathrm{E}-6 \\
(0.0054)\end{array}$ & $\begin{array}{l}<7.3 \mathrm{E}-6 \\
<(0.014)\end{array}$ & $\begin{array}{l}<3.4 \mathrm{E}-3 \\
<(6.582)\end{array}$ & $\begin{array}{l}<7.9 \mathrm{E}-6 \\
<(0.015)\end{array}$ & $\begin{array}{c}4.57 \mathrm{E}-6 \\
(0.0088)\end{array}$ & $\begin{array}{c}1.19 \mathrm{E}-5 \\
(0.023)\end{array}$ & $\begin{array}{l}<1.6 \mathrm{E}-6 \\
<(0.003)\end{array}$ & $\begin{array}{l}<7.0 \mathrm{E}-6 \\
<(0.013)\end{array}$ & $\begin{array}{l}<5.2 \mathrm{E}-6 \\
<(0.010)\end{array}$ \\
\hline Postburn particle leach $1^{a}$ & $\begin{array}{c}5.35 \mathrm{E}-5 \\
(0.103)\end{array}$ & $\begin{array}{l}<7.9 \mathrm{E}-5 \\
<(0.151)\end{array}$ & $\begin{array}{c}<3.0 \mathrm{E}-2 \\
<(56.925)\end{array}$ & $\begin{array}{l}<7.8 \mathrm{E}-5 \\
<(0.149)\end{array}$ & $\begin{array}{c}5.09 \mathrm{E}-5 \\
(0.098)\end{array}$ & $\begin{array}{c}1.06 \mathrm{E}-4 \\
(0.203)\end{array}$ & $\begin{array}{l}<1.9 \mathrm{E}-5 \\
<(0.037)\end{array}$ & $\begin{array}{c}1.92 \mathrm{E}-4 \\
(0.368)\end{array}$ & $\begin{array}{c}1.32 \mathrm{E}-4 \\
(0.253)\end{array}$ \\
\hline Postburn particle leach $2^{a}$ & $\begin{array}{c}1.66 \mathrm{E}-6 \\
(0.0032)\end{array}$ & $\begin{array}{l}<1.4 \mathrm{E}-5 \\
<(0.028)\end{array}$ & $\begin{array}{c}<1.3 \mathrm{E}-2 \\
<(24.970)\end{array}$ & $\begin{array}{l}<1.2 \mathrm{E}-5 \\
<(0.022)\end{array}$ & $\begin{array}{l}4.01 \mathrm{E}-6 \\
(0.0077)\end{array}$ & $\begin{array}{c}4.74 \mathrm{E}-6 \\
(0.0091)\end{array}$ & $\begin{array}{c}<3.5 \mathrm{E}-6 \\
<(0.0068)\end{array}$ & $\begin{array}{l}<1.8 \mathrm{E}-5 \\
<(0.034)\end{array}$ & $\begin{array}{l}<9.8 \mathrm{E}-6 \\
<(0.019)\end{array}$ \\
\hline Total & $\begin{array}{c}3.76 \mathrm{E}-4 \\
(0.722)\end{array}$ & $\begin{array}{c}1.10 \mathrm{E}-4 \\
(0.211)\end{array}$ & $\begin{array}{c}0.00 \mathrm{E}+0 \\
(0.000)\end{array}$ & $\begin{array}{l}1.80 \mathrm{E}-5 \\
(0.035)\end{array}$ & $\begin{array}{c}5.69 \mathrm{E}-4 \\
(1.090)\end{array}$ & $\begin{array}{c}8.26 \mathrm{E}-4 \\
(1.585)\end{array}$ & $\begin{array}{c}3.45 \mathrm{E}-4 \\
(0.662)\end{array}$ & $\begin{array}{c}5.94 \mathrm{E}-4 \\
(1.140)\end{array}$ & $\begin{array}{c}5.57 \mathrm{E}-4 \\
(1.068)\end{array}$ \\
\hline
\end{tabular}

Note: Chemical separation and beta analysis were used to measure ${ }^{90} \mathrm{Sr}$; other nuclides were measured by gamma spectrometry.

Note: Values are reported as compact inventory fractions and particle equivalents (in parentheses).

Note: A less-than value indicates that the concentration in the leachate was below the minimum detectable limit; these values are not included in the totals.

${ }^{a}$ Postburn particle leach data were scaled to account for $\sim 14 \%$ particle population withheld from postburn analysis. 
Appendix Table A-10. Typically tracked beta/gamma-emitting fission products detected by DLBL of AGR-3/4 Compact 1-4 Segment 3

\begin{tabular}{|c|c|c|c|c|c|c|c|c|c|}
\hline DLBL Step & ${ }^{90} \mathrm{Sr}$ & ${ }^{106} \mathrm{Ru}$ & ${ }^{110 m} \mathrm{Ag}$ & ${ }^{125} \mathrm{Sb}$ & ${ }^{134} \mathrm{Cs}$ & ${ }^{137} \mathrm{Cs}$ & ${ }^{144} \mathrm{Ce}$ & ${ }^{154} \mathbf{E u}$ & ${ }^{155} \mathbf{E u}$ \\
\hline Deconsolidation acid & $\begin{array}{c}5.07 \mathrm{E}-4 \\
(0.973)\end{array}$ & $\begin{array}{c}2.01 \mathrm{E}-4 \\
(0.386)\end{array}$ & $\begin{array}{c}<3.1 \mathrm{E}-2 \\
<(60.041)\end{array}$ & $\begin{array}{l}<1.3 \mathrm{E}-4 \\
<(0.240)\end{array}$ & $\begin{array}{c}8.29 \mathrm{E}-4 \\
(1.590)\end{array}$ & $\begin{array}{c}1.10 \mathrm{E}-3 \\
(2.106)\end{array}$ & $\begin{array}{c}4.89 \mathrm{E}-4 \\
(0.938)\end{array}$ & $\begin{array}{c}4.66 \mathrm{E}-4 \\
(0.894)\end{array}$ & $\begin{array}{c}4.97 \mathrm{E}-4 \\
(0.953)\end{array}$ \\
\hline Preburn leach 1 & $\begin{array}{l}2.86 \mathrm{E}-6 \\
(0.0055)\end{array}$ & $\begin{array}{l}<1.2 \mathrm{E}-5 \\
<(0.024)\end{array}$ & $\begin{array}{c}<7.4 \mathrm{E}-3 \\
<(14.173)\end{array}$ & $\begin{array}{l}<9.7 \mathrm{E}-6 \\
<(0.019)\end{array}$ & $\begin{array}{c}<6.8 \mathrm{E}-7 \\
<(0.0013)\end{array}$ & $\begin{array}{l}4.21 \mathrm{E}-6 \\
(0.0081)\end{array}$ & $\begin{array}{l}<2.4 \mathrm{E}-6 \\
<(0.0047)\end{array}$ & $\begin{array}{l}<1.5 \mathrm{E}-5 \\
<(0.030)\end{array}$ & $\begin{array}{l}<8.5 \mathrm{E}-6 \\
<(0.016)\end{array}$ \\
\hline Preburn leach 2 & $\begin{array}{c}6.93 \mathrm{E}-6 \\
(0.013)\end{array}$ & $\begin{array}{c}1.61 \mathrm{E}-5 \\
(0.031)\end{array}$ & $\begin{array}{c}<1.7 \mathrm{E}-2 \\
<(32.163)\end{array}$ & $\begin{array}{l}<3.6 \mathrm{E}-5 \\
<(0.070)\end{array}$ & $\begin{array}{c}1.16 \mathrm{E}-5 \\
(0.022)\end{array}$ & $\begin{array}{c}1.99 \mathrm{E}-5 \\
(0.038)\end{array}$ & $\begin{array}{l}<7.6 \mathrm{E}-6 \\
<(0.015)\end{array}$ & $\begin{array}{l}<3.1 \mathrm{E}-5 \\
<(0.059)\end{array}$ & $\begin{array}{l}<3.5 \mathrm{E}-5 \\
<(0.066)\end{array}$ \\
\hline Postburn matrix leach 1 & $\begin{array}{c}3.29 \mathrm{E}-5 \\
(0.063)\end{array}$ & $\begin{array}{l}<1.3 \mathrm{E}-5 \\
<(0.026)\end{array}$ & $\begin{array}{c}<6.4 \mathrm{E}-3 \\
<(12.272)\end{array}$ & $\begin{array}{l}<1.5 \mathrm{E}-5 \\
<(0.028)\end{array}$ & $\begin{array}{c}7.98 \mathrm{E}-6 \\
(0.015)\end{array}$ & $\begin{array}{c}3.33 \mathrm{E}-5 \\
(0.064)\end{array}$ & $\begin{array}{l}2.44 \mathrm{E}-6 \\
(0.0047)\end{array}$ & $\begin{array}{c}7.42 \mathrm{E}-5 \\
(0.142)\end{array}$ & $\begin{array}{c}4.39 \mathrm{E}-5 \\
(0.084)\end{array}$ \\
\hline Postburn matrix leach 2 & $\begin{array}{l}2.54 \mathrm{E}-6 \\
(0.0049)\end{array}$ & $\begin{array}{l}<7.6 \mathrm{E}-6 \\
<(0.015)\end{array}$ & $\begin{array}{l}<5.0 \mathrm{E}-3 \\
<(9.602)\end{array}$ & $\begin{array}{l}<7.1 \mathrm{E}-6 \\
<(0.014)\end{array}$ & $\begin{array}{l}2.33 \mathrm{E}-6 \\
(0.0045)\end{array}$ & $\begin{array}{l}5.03 \mathrm{E}-6 \\
(0.0097)\end{array}$ & $\begin{array}{c}<1.6 \mathrm{E}-6 \\
<(0.0032)\end{array}$ & $\begin{array}{c}6.37 \mathrm{E}-6 \\
(0.012)\end{array}$ & $\begin{array}{l}<5.9 \mathrm{E}-6 \\
<(0.011)\end{array}$ \\
\hline Postburn particle leach $1^{a}$ & $\begin{array}{c}2.06 \mathrm{E}-5 \\
(0.039)\end{array}$ & $\begin{array}{l}<3.9 \mathrm{E}-5 \\
<(0.075)\end{array}$ & $\begin{array}{c}<1.7 \mathrm{E}-2 \\
<(33.562)\end{array}$ & $\begin{array}{l}<3.6 \mathrm{E}-5 \\
<(0.070)\end{array}$ & $\begin{array}{l}4.75 \mathrm{E}-6 \\
(0.0091)\end{array}$ & $\begin{array}{c}2.78 \mathrm{E}-5 \\
(0.053)\end{array}$ & $\begin{array}{l}<1.0 \mathrm{E}-5 \\
<(0.020)\end{array}$ & $\begin{array}{c}5.89 \mathrm{E}-5 \\
(0.113)\end{array}$ & $\begin{array}{l}<3.7 \mathrm{E}-5 \\
<(0.070)\end{array}$ \\
\hline Postburn particle leach $2^{a}$ & $\begin{array}{c}1.08 \mathrm{E}-5 \\
(0.021)\end{array}$ & $\begin{array}{l}<1.8 \mathrm{E}-5 \\
<(0.034)\end{array}$ & $\begin{array}{c}<9.9 \mathrm{E}-3 \\
<(18.954)\end{array}$ & $\begin{array}{l}<1.6 \mathrm{E}-5 \\
<(0.031)\end{array}$ & $\begin{array}{c}2.61 \mathrm{E}-6 \\
(0.005)\end{array}$ & $\begin{array}{c}1.70 \mathrm{E}-5 \\
(0.033)\end{array}$ & $\begin{array}{c}<4.3 \mathrm{E}-6 \\
<(0.0083)\end{array}$ & $\begin{array}{c}2.24 \mathrm{E}-5 \\
(0.043)\end{array}$ & $\begin{array}{l}<1.0 \mathrm{E}-5 \\
<(0.020)\end{array}$ \\
\hline Total & $\begin{array}{c}5.84 \mathrm{E}-4 \\
(1.120)\end{array}$ & $\begin{array}{c}2.17 \mathrm{E}-4 \\
(0.417)\end{array}$ & $\begin{array}{c}0.00 \mathrm{E}+0 \\
(0.000)\end{array}$ & $\begin{array}{c}0.00 \mathrm{E}+0 \\
(0.000)\end{array}$ & $\begin{array}{c}8.58 \mathrm{E}-4 \\
(1.646)\end{array}$ & $\begin{array}{l}1.21 \mathrm{E}-3 \\
(2.312)\end{array}$ & $\begin{array}{c}4.91 \mathrm{E}-4 \\
(0.943)\end{array}$ & $\begin{array}{c}6.28 \mathrm{E}-4 \\
(1.204)\end{array}$ & $\begin{array}{c}5.41 \mathrm{E}-4 \\
(1.037)\end{array}$ \\
\hline
\end{tabular}

Note: Chemical separation and beta analysis were used to measure ${ }^{90} \mathrm{Sr}$; other nuclides were measured by gamma spectrometry.

Note: Values are reported as compact inventory fractions and particle equivalents (in parentheses).

Note: A less-than value indicates that the concentration in the leachate was below the minimum detectable limit; these values are not included in the totals.

${ }^{a}$ Because most of the particles deconsolidated from Segment 3 were lost when sieve stack was knocked over, only $2 \%$ of the particles were included in

postburn particle leach and data were not scaled. 
Appendix Table A-11. Typically tracked beta/gamma-emitting fission products detected by DLBL of AGR-3/4 Compact 1-4 Segment 4

\begin{tabular}{|c|c|c|c|c|c|c|c|c|c|}
\hline DLBL Step & ${ }^{90} \mathrm{Sr}$ & ${ }^{106} \mathbf{R u}$ & ${ }^{110 m} \mathrm{Ag}$ & ${ }^{125} \mathrm{Sb}$ & ${ }^{134} \mathrm{Cs}$ & ${ }^{137} \mathrm{Cs}$ & ${ }^{144} \mathrm{Ce}$ & ${ }^{154} \mathbf{E u}$ & ${ }^{155} \mathbf{E u}$ \\
\hline Deconsolidation acid & $\begin{array}{l}1.10 \mathrm{E}-2 \\
(21.092)\end{array}$ & $\begin{array}{c}6.04 \mathrm{E}-3 \\
(11.592)\end{array}$ & $\begin{array}{c}<1.0 \mathrm{E}-1 \\
<(195.455)\end{array}$ & $\begin{array}{l}1.83 \mathrm{E}-3 \\
(3.500)\end{array}$ & $\begin{array}{l}5.19 \mathrm{E}-3 \\
(9.945)\end{array}$ & $\begin{array}{c}6.95 \mathrm{E}-3 \\
(13.336)\end{array}$ & $\begin{array}{l}9.04 \mathrm{E}-3 \\
(17.332)\end{array}$ & $\begin{array}{c}7.02 \mathrm{E}-3 \\
(13.467)\end{array}$ & $\begin{array}{c}7.20 \mathrm{E}-3 \\
(13.805)\end{array}$ \\
\hline Preburn leach 1 & $\begin{array}{c}8.50 \mathrm{E}-5 \\
(0.163)\end{array}$ & $\begin{array}{l}1.14 \mathrm{E}-3 \\
(2.184)\end{array}$ & $\begin{array}{c}<2.9 \mathrm{E}-2 \\
<(56.395)\end{array}$ & $\begin{array}{c}5.07 \mathrm{E}-4 \\
(0.973)\end{array}$ & $\begin{array}{c}6.72 \mathrm{E}-4 \\
(1.289)\end{array}$ & $\begin{array}{c}8.44 \mathrm{E}-4 \\
(1.618)\end{array}$ & $\begin{array}{l}7.47 \mathrm{E}-5 \\
(0.143)\end{array}$ & $\begin{array}{l}8.53 \mathrm{E}-5 \\
(0.164)\end{array}$ & $\begin{array}{l}7.90 \mathrm{E}-5 \\
(0.152)\end{array}$ \\
\hline Preburn leach 2 & $\begin{array}{l}1.87 \mathrm{E}-5 \\
(0.036)\end{array}$ & $\begin{array}{l}1.55 \mathrm{E}-4 \\
(0.297)\end{array}$ & $\begin{array}{c}<1.3 \mathrm{E}-2 \\
<(25.776)\end{array}$ & $\begin{array}{c}8.16 \mathrm{E}-4 \\
(1.566)\end{array}$ & $\begin{array}{c}4.65 \mathrm{E}-5 \\
(0.089)\end{array}$ & $\begin{array}{c}6.03 \mathrm{E}-5 \\
(0.116)\end{array}$ & $\begin{array}{c}2.81 \mathrm{E}-5 \\
(0.054)\end{array}$ & $\begin{array}{c}2.21 \mathrm{E}-5 \\
(0.042)\end{array}$ & $\begin{array}{l}1.36 \mathrm{E}-5 \\
(0.026)\end{array}$ \\
\hline Postburn matrix leach 1 & $\begin{array}{c}2.36 \mathrm{E}-4 \\
(0.452)\end{array}$ & $\begin{array}{c}4.74 \mathrm{E}-5 \\
(0.091)\end{array}$ & $\begin{array}{l}<9.4 \mathrm{E}-3 \\
<(18.078)\end{array}$ & $\begin{array}{c}9.15 \mathrm{E}-4 \\
(1.754)\end{array}$ & $\begin{array}{c}3.44 \mathrm{E}-5 \\
(0.066)\end{array}$ & $\begin{array}{c}6.09 \mathrm{E}-5 \\
(0.117)\end{array}$ & $\begin{array}{c}8.62 \mathrm{E}-5 \\
(0.165)\end{array}$ & $\begin{array}{c}2.22 \mathrm{E}-4 \\
(0.425)\end{array}$ & $\begin{array}{c}1.98 \mathrm{E}-4 \\
(0.380)\end{array}$ \\
\hline Postburn matrix leach 2 & $\begin{array}{l}4.90 \mathrm{E}-6 \\
(0.0094)\end{array}$ & $\begin{array}{l}<1.3 \mathrm{E}-5 \\
<(0.024)\end{array}$ & $\begin{array}{c}<7.3 \mathrm{E}-3 \\
<(14.023)\end{array}$ & $\begin{array}{c}9.73 \mathrm{E}-5 \\
(0.187)\end{array}$ & $\begin{array}{l}2.46 \mathrm{E}-6 \\
(0.0047)\end{array}$ & $\begin{array}{l}3.98 \mathrm{E}-6 \\
(0.0076)\end{array}$ & $\begin{array}{l}2.43 \mathrm{E}-6 \\
(0.0047)\end{array}$ & $\begin{array}{l}<1.2 \mathrm{E}-5 \\
<(0.022)\end{array}$ & $\begin{array}{l}<1.3 \mathrm{E}-5 \\
<(0.025)\end{array}$ \\
\hline Postburn particle leach $1^{a}$ & $\begin{array}{c}3.18 \mathrm{E}-4 \\
(0.610)\end{array}$ & $\begin{array}{l}<6.4 \mathrm{E}-5 \\
<(0.123)\end{array}$ & $\begin{array}{c}<3.0 \mathrm{E}-2 \\
<(56.639)\end{array}$ & $\begin{array}{l}<1.2 \mathrm{E}-5 \\
<(0.022)\end{array}$ & $\begin{array}{c}3.48 \mathrm{E}-5 \\
(0.067)\end{array}$ & $\begin{array}{c}6.69 \mathrm{E}-5 \\
(0.128)\end{array}$ & $\begin{array}{c}2.88 \mathrm{E}-4 \\
(0.553)\end{array}$ & $\begin{array}{c}3.05 \mathrm{E}-4 \\
(0.585)\end{array}$ & $\begin{array}{c}3.08 \mathrm{E}-4 \\
(0.590)\end{array}$ \\
\hline Postburn particle leach $2^{a}$ & $\begin{array}{c}6.27 \mathrm{E}-6 \\
(0.012)\end{array}$ & $\begin{array}{l}<1.7 \mathrm{E}-5 \\
<(0.032)\end{array}$ & $\begin{array}{c}<1.0 \mathrm{E}-2 \\
<(19.224)\end{array}$ & $\begin{array}{l}<1.8 \mathrm{E}-5 \\
<(0.034)\end{array}$ & $\begin{array}{l}2.75 \mathrm{E}-6 \\
(0.0053)\end{array}$ & $\begin{array}{l}1.68 \mathrm{E}-5 \\
(0.032)\end{array}$ & $\begin{array}{l}<4.5 \mathrm{E}-6 \\
<(0.0086)\end{array}$ & $\begin{array}{l}<1.5 \mathrm{E}-5 \\
<(0.028)\end{array}$ & $\begin{array}{l}<1.2 \mathrm{E}-5 \\
<(0.023)\end{array}$ \\
\hline Total & $\begin{array}{c}1.17 \mathrm{E}-2 \\
(22.375)\end{array}$ & $\begin{array}{c}7.38 \mathrm{E}-3 \\
(14.164)\end{array}$ & $\begin{array}{c}0.00 \mathrm{E}+0 \\
(0.000)\end{array}$ & $\begin{array}{c}4.16 \mathrm{E}-3 \\
(7.980)\end{array}$ & $\begin{array}{c}5.98 \mathrm{E}-3 \\
(11.466)\end{array}$ & $\begin{array}{c}8.01 \mathrm{E}-3 \\
(15.355)\end{array}$ & $\begin{array}{c}9.52 \mathrm{E}-3 \\
(18.253)\end{array}$ & $\begin{array}{c}7.66 \mathrm{E}-3 \\
(14.683)\end{array}$ & $\begin{array}{c}7.80 \mathrm{E}-3 \\
(14.953)\end{array}$ \\
\hline
\end{tabular}

Note: Chemical separation and beta analysis were used to measure ${ }^{90} \mathrm{Sr}$; other nuclides were measured by gamma spectrometry.

Note: Values are reported as compact inventory fractions and particle equivalents (in parentheses).

Note: A less-than value indicates that the concentration in the leachate was below the minimum detectable limit; these values are not included in the totals.

${ }^{a}$ Postburn particle leach data were scaled to account for $\sim 15 \%$ particle population withheld from postburn analysis. 
Appendix Table A-12. Typically tracked beta/gamma-emitting fission products detected by DLBL of AGR-3/4 Compact 10-4 Segment 1

\begin{tabular}{|c|c|c|c|c|c|c|c|c|c|}
\hline DLBL Step & ${ }^{90} \mathrm{Sr}$ & ${ }^{106} \mathbf{R u}$ & ${ }^{110 \mathrm{~m}} \mathrm{Ag}$ & ${ }^{125} \mathrm{Sb}$ & ${ }^{134} \mathrm{Cs}$ & ${ }^{137} \mathrm{Cs}$ & ${ }^{144} \mathrm{Ce}$ & ${ }^{154} \mathbf{E u}$ & ${ }^{155} \mathbf{E u}$ \\
\hline Deconsolidation acid & $\begin{array}{c}2.86 \mathrm{E}-4 \\
(0.548)\end{array}$ & $\begin{array}{l}1.98 \mathrm{E}-5 \\
(0.038)\end{array}$ & $\begin{array}{l}<4.1 \mathrm{E}-3 \\
<(7.824)\end{array}$ & $\begin{array}{c}3.43 \mathrm{E}-5 \\
(0.066)\end{array}$ & $\begin{array}{c}4.77 \mathrm{E}-6 \\
(0.0091)\end{array}$ & $\begin{array}{c}2.87 \mathrm{E}-5 \\
(0.055)\end{array}$ & $\begin{array}{l}1.91 \mathrm{E}-5 \\
(0.037)\end{array}$ & $\begin{array}{l}1.88 \mathrm{E}-4 \\
(0.361)\end{array}$ & $\begin{array}{c}2.10 \mathrm{E}-4 \\
(0.403)\end{array}$ \\
\hline Preburn leach 1 & $\begin{array}{c}5.98 \mathrm{E}-5 \\
(0.115)\end{array}$ & $\begin{array}{l}<1.0 \mathrm{E}-5 \\
<(0.020)\end{array}$ & $\begin{array}{l}<4.0 \mathrm{E}-3 \\
<(7.766)\end{array}$ & $\begin{array}{l}1.75 \mathrm{E}-5 \\
(0.034)\end{array}$ & $\begin{array}{l}3.11 \mathrm{E}-7 \\
(0.0006)\end{array}$ & $\begin{array}{l}2.18 \mathrm{E}-6 \\
(0.0042)\end{array}$ & $\begin{array}{c}<2.7 \mathrm{E}-6 \\
<(0.0052)\end{array}$ & $\begin{array}{c}1.43 \mathrm{E}-4 \\
(0.275)\end{array}$ & $\begin{array}{c}1.43 \mathrm{E}-4 \\
(0.274)\end{array}$ \\
\hline Preburn leach 2 & $\begin{array}{c}9.86 \mathrm{E}-6 \\
(0.019)\end{array}$ & $\begin{array}{l}<1.0 \mathrm{E}-5 \\
<(0.019)\end{array}$ & $\begin{array}{l}<3.6 \mathrm{E}-3 \\
<(6.960)\end{array}$ & $\begin{array}{l}<8.9 \mathrm{E}-6 \\
<(0.017)\end{array}$ & $\begin{array}{l}2.09 \mathrm{E}-7 \\
(0.0004)\end{array}$ & $\begin{array}{c}1.28 \mathrm{E}-6 \\
(0.0024)\end{array}$ & $\begin{array}{l}<3.7 \mathrm{E}-6 \\
<(0.007)\end{array}$ & $\begin{array}{c}4.89 \mathrm{E}-5 \\
(0.094)\end{array}$ & $\begin{array}{c}4.60 \mathrm{E}-5 \\
(0.088)\end{array}$ \\
\hline Postburn matrix leach 1 & $\begin{array}{c}4.60 \mathrm{E}-4 \\
(0.883)\end{array}$ & $\begin{array}{l}<9.7 \mathrm{E}-6 \\
<(0.019)\end{array}$ & $\begin{array}{l}<3.4 \mathrm{E}-3 \\
<(6.541)\end{array}$ & $\begin{array}{c}1.89 \mathrm{E}-5 \\
(0.036)\end{array}$ & $\begin{array}{l}2.02 \mathrm{E}-6 \\
(0.0039)\end{array}$ & $\begin{array}{c}1.93 \mathrm{E}-5 \\
(0.037)\end{array}$ & $\begin{array}{c}<3.5 \mathrm{E}-6 \\
<(0.0066)\end{array}$ & $\begin{array}{c}3.81 \mathrm{E}-4 \\
(0.730)\end{array}$ & $\begin{array}{c}3.95 \mathrm{E}-4 \\
(0.758)\end{array}$ \\
\hline Postburn matrix leach 2 & $\begin{array}{l}1.27 \mathrm{E}-5 \\
(0.024)\end{array}$ & $\begin{array}{c}<4.4 \mathrm{E}-6 \\
<(0.0084)\end{array}$ & $\begin{array}{l}<1.2 \mathrm{E}-3 \\
<(2.354)\end{array}$ & $\begin{array}{c}<4.7 \mathrm{E}-6 \\
<(0.0089)\end{array}$ & $\begin{array}{c}2.57 \mathrm{E}-7 \\
(0.0005)\end{array}$ & $\begin{array}{c}3.21 \mathrm{E}-6 \\
(0.0061)\end{array}$ & $\begin{array}{c}<1.2 \mathrm{E}-6 \\
<(0.0024)\end{array}$ & $\begin{array}{l}1.02 \mathrm{E}-5 \\
(0.020)\end{array}$ & $\begin{array}{l}1.13 \mathrm{E}-5 \\
(0.022)\end{array}$ \\
\hline Postburn particle leach $1^{a}$ & $\begin{array}{l}1.95 \mathrm{E}-4 \\
(0.375)\end{array}$ & $\begin{array}{l}<3.2 \mathrm{E}-5 \\
<(0.061)\end{array}$ & $\begin{array}{c}<8.0 \mathrm{E}-3 \\
<(15.275)\end{array}$ & $\begin{array}{l}<3.5 \mathrm{E}-5 \\
<(0.068)\end{array}$ & $\begin{array}{l}4.42 \mathrm{E}-6 \\
(0.0085)\end{array}$ & $\begin{array}{c}4.42 \mathrm{E}-5 \\
(0.085)\end{array}$ & $\begin{array}{l}1.06 \mathrm{E}-5 \\
(0.020)\end{array}$ & $\begin{array}{c}1.93 \mathrm{E}-4 \\
(0.371)\end{array}$ & $\begin{array}{c}1.73 E-4 \\
(0.332)\end{array}$ \\
\hline Postburn particle leach $2^{a}$ & $\begin{array}{c}4.94 \mathrm{E}-6 \\
(0.0095)\end{array}$ & $\begin{array}{l}<7.8 \mathrm{E}-6 \\
<(0.015)\end{array}$ & $\begin{array}{l}<2.2 \mathrm{E}-3 \\
<(4.229)\end{array}$ & $\begin{array}{l}<8.0 \mathrm{E}-6 \\
<(0.015)\end{array}$ & $\begin{array}{c}8.54 \mathrm{E}-7 \\
(0.0016)\end{array}$ & $\begin{array}{c}7.16 \mathrm{E}-6 \\
(0.014)\end{array}$ & $\begin{array}{c}<2.5 \mathrm{E}-6 \\
<(0.0048)\end{array}$ & $\begin{array}{l}<6.0 \mathrm{E}-6 \\
<(0.012)\end{array}$ & $\begin{array}{c}<5.0 \mathrm{E}-6 \\
<(0.0097)\end{array}$ \\
\hline Total & $\begin{array}{l}1.03 \mathrm{E}-3 \\
(1.973)\end{array}$ & $\begin{array}{c}1.98 \mathrm{E}-5 \\
(0.038)\end{array}$ & $\begin{array}{c}0.00 \mathrm{E}+0 \\
(0.000)\end{array}$ & $\begin{array}{c}7.08 \mathrm{E}-5 \\
(0.136)\end{array}$ & $\begin{array}{l}1.28 \mathrm{E}-5 \\
(0.025)\end{array}$ & $\begin{array}{c}1.06 \mathrm{E}-4 \\
(0.203)\end{array}$ & $\begin{array}{c}2.97 \mathrm{E}-5 \\
(0.057)\end{array}$ & $\begin{array}{c}9.65 \mathrm{E}-4 \\
(1.850)\end{array}$ & $\begin{array}{c}9.79 \mathrm{E}-4 \\
(1.877)\end{array}$ \\
\hline
\end{tabular}

Note: Chemical separation and beta analysis were used to measure ${ }^{90} \mathrm{Sr}$; other nuclides were measured by gamma spectrometry.

Note: Values are reported as compact inventory fractions and particle equivalents (in parentheses).

Note: A less-than value indicates that the concentration in the leachate was below the minimum detectable limit; these values are not included in the totals.

${ }^{a}$ Postburn particle leach data were scaled to account for $\sim 8 \%$ particle population withheld from postburn analysis. 
Appendix Table A-13. Typically tracked beta/gamma-emitting fission products detected by DLBL of AGR-3/4 Compact 10-4 Segment 2

\begin{tabular}{|c|c|c|c|c|c|c|c|c|c|}
\hline DLBL Step & ${ }^{90} \mathrm{Sr}$ & ${ }^{106} \mathrm{Ru}$ & ${ }^{110 m} \mathrm{Ag}$ & ${ }^{125} \mathrm{Sb}$ & ${ }^{134} \mathrm{Cs}$ & ${ }^{137} \mathrm{Cs}$ & ${ }^{144} \mathrm{Ce}$ & ${ }^{154} \mathbf{E u}$ & ${ }^{155} \mathbf{E u}$ \\
\hline Deconsolidation acid & $\begin{array}{c}4.40 \mathrm{E}-4 \\
(0.844)\end{array}$ & $\begin{array}{c}1.13 \mathrm{E}-4 \\
(0.217)\end{array}$ & $\begin{array}{l}<4.1 \mathrm{E}-3 \\
<(7.822)\end{array}$ & $\begin{array}{l}<2.3 \mathrm{E}-5 \\
<(0.044)\end{array}$ & $\begin{array}{c}2.68 \mathrm{E}-5 \\
(0.051)\end{array}$ & $\begin{array}{c}1.13 \mathrm{E}-4 \\
(0.217)\end{array}$ & $\begin{array}{c}8.98 \mathrm{E}-5 \\
(0.172)\end{array}$ & $\begin{array}{c}2.65 \mathrm{E}-4 \\
(0.508)\end{array}$ & $\begin{array}{c}2.90 \mathrm{E}-4 \\
(0.557)\end{array}$ \\
\hline Preburn leach 1 & $\begin{array}{c}9.00 \mathrm{E}-5 \\
(0.173)\end{array}$ & $\begin{array}{c}1.56 \mathrm{E}-5 \\
(0.030)\end{array}$ & $\begin{array}{l}<3.6 \mathrm{E}-3 \\
<(6.975)\end{array}$ & $\begin{array}{c}1.69 \mathrm{E}-5 \\
(0.032)\end{array}$ & $\begin{array}{c}7.87 \mathrm{E}-7 \\
(0.0015)\end{array}$ & $\begin{array}{c}5.76 \mathrm{E}-6 \\
(0.011)\end{array}$ & $\begin{array}{c}<3.0 \mathrm{E}-6 \\
<(0.0058)\end{array}$ & $\begin{array}{c}1.58 \mathrm{E}-4 \\
(0.304)\end{array}$ & $\begin{array}{c}1.65 \mathrm{E}-4 \\
(0.317)\end{array}$ \\
\hline Preburn leach 2 & $\begin{array}{c}4.31 \mathrm{E}-5 \\
(0.083)\end{array}$ & $\begin{array}{l}<1.1 \mathrm{E}-5 \\
<(0.020)\end{array}$ & $\begin{array}{l}<3.9 \mathrm{E}-3 \\
<(7.417)\end{array}$ & $\begin{array}{l}<9.7 \mathrm{E}-6 \\
<(0.019)\end{array}$ & $\begin{array}{c}<4.3 \mathrm{E}-7 \\
<(0.0008)\end{array}$ & $\begin{array}{l}2.30 \mathrm{E}-6 \\
(0.0044)\end{array}$ & $\begin{array}{c}<3.6 \mathrm{E}-6 \\
<(0.0068)\end{array}$ & $\begin{array}{c}3.79 \mathrm{E}-5 \\
(0.073)\end{array}$ & $\begin{array}{c}3.88 \mathrm{E}-5 \\
(0.074)\end{array}$ \\
\hline Postburn matrix leach 1 & $\begin{array}{c}4.83 \mathrm{E}-4 \\
(0.925)\end{array}$ & $\begin{array}{l}<1.3 \mathrm{E}-5 \\
<(0.026)\end{array}$ & $\begin{array}{l}<4.8 \mathrm{E}-3 \\
<(9.237)\end{array}$ & $\begin{array}{c}1.05 \mathrm{E}-5 \\
(0.020)\end{array}$ & $\begin{array}{c}1.53 \mathrm{E}-6 \\
(0.0029)\end{array}$ & $\begin{array}{l}1.50 \mathrm{E}-5 \\
(0.029)\end{array}$ & $\begin{array}{c}<4.1 \mathrm{E}-6 \\
<(0.0078)\end{array}$ & $\begin{array}{c}4.92 \mathrm{E}-4 \\
(0.944)\end{array}$ & $\begin{array}{c}4.70 \mathrm{E}-4 \\
(0.901)\end{array}$ \\
\hline Postburn matrix leach 2 & $\begin{array}{c}1.21 \mathrm{E}-5 \\
(0.023)\end{array}$ & $\begin{array}{l}<8.2 \mathrm{E}-6 \\
<(0.016)\end{array}$ & $\begin{array}{l}<2.5 \mathrm{E}-3 \\
<(4.800)\end{array}$ & $\begin{array}{l}<8.9 \mathrm{E}-6 \\
<(0.017)\end{array}$ & $\begin{array}{c}1.56 \mathrm{E}-6 \\
(0.003)\end{array}$ & $\begin{array}{l}4.57 \mathrm{E}-6 \\
(0.0088)\end{array}$ & $\begin{array}{l}<2.7 \mathrm{E}-6 \\
<(0.0051)\end{array}$ & $\begin{array}{c}1.14 \mathrm{E}-5 \\
(0.022)\end{array}$ & $\begin{array}{l}1.36 \mathrm{E}-5 \\
(0.026)\end{array}$ \\
\hline Postburn particle leach $1^{a}$ & $\begin{array}{c}2.05 \mathrm{E}-4 \\
(0.393)\end{array}$ & $\begin{array}{l}<2.9 \mathrm{E}-5 \\
<(0.056)\end{array}$ & $\begin{array}{c}<8.4 \mathrm{E}-3 \\
<(16.189)\end{array}$ & $\begin{array}{l}<3.1 \mathrm{E}-5 \\
<(0.059)\end{array}$ & $\begin{array}{l}2.66 \mathrm{E}-6 \\
(0.0051)\end{array}$ & $\begin{array}{c}2.94 \mathrm{E}-5 \\
(0.056)\end{array}$ & $\begin{array}{l}<6.7 \mathrm{E}-6 \\
<(0.013)\end{array}$ & $\begin{array}{c}2.21 \mathrm{E}-4 \\
(0.424)\end{array}$ & $\begin{array}{c}1.94 \mathrm{E}-4 \\
(0.372)\end{array}$ \\
\hline Postburn particle leach $2^{a}$ & $\begin{array}{c}6.02 \mathrm{E}-6 \\
(0.012)\end{array}$ & $\begin{array}{l}<8.3 \mathrm{E}-6 \\
<(0.016)\end{array}$ & $\begin{array}{l}<2.6 \mathrm{E}-3 \\
<(5.001)\end{array}$ & $\begin{array}{l}<9.6 \mathrm{E}-6 \\
<(0.018)\end{array}$ & $\begin{array}{c}7.78 \mathrm{E}-7 \\
(0.0015)\end{array}$ & $\begin{array}{c}1.02 \mathrm{E}-5 \\
(0.020)\end{array}$ & $\begin{array}{c}<2.8 \mathrm{E}-6 \\
<(0.0053)\end{array}$ & $\begin{array}{c}9.05 \mathrm{E}-6 \\
(0.017)\end{array}$ & $\begin{array}{c}4.71 \mathrm{E}-6 \\
(0.009)\end{array}$ \\
\hline Total & $\begin{array}{c}1.28 \mathrm{E}-3 \\
(2.452)\end{array}$ & $\begin{array}{c}1.28 \mathrm{E}-4 \\
(0.246)\end{array}$ & $\begin{array}{c}0.00 \mathrm{E}+0 \\
(0.000)\end{array}$ & $\begin{array}{c}2.74 \mathrm{E}-5 \\
(0.053)\end{array}$ & $\begin{array}{c}3.41 \mathrm{E}-5 \\
(0.065)\end{array}$ & $\begin{array}{c}1.81 \mathrm{E}-4 \\
(0.346)\end{array}$ & $\begin{array}{c}8.98 \mathrm{E}-5 \\
(0.172)\end{array}$ & $\begin{array}{l}1.19 \mathrm{E}-3 \\
(2.291)\end{array}$ & $\begin{array}{c}1.18 \mathrm{E}-3 \\
(2.256)\end{array}$ \\
\hline
\end{tabular}

Note: Chemical separation and beta analysis were used to measure ${ }^{90} \mathrm{Sr}$; other nuclides were measured by gamma spectrometry.

Note: Values are reported as compact inventory fractions and particle equivalents (in parentheses).

Note: A less-than value indicates that the concentration in the leachate was below the minimum detectable limit; these values are not included in the totals.

${ }^{a}$ Postburn particle leach data were scaled to account for $\sim 10 \%$ particle population withheld from postburn analysis. 
Appendix Table A-14. Typically tracked beta/gamma-emitting fission products detected by DLBL of AGR-3/4 Compact 10-4 Segment 3

\begin{tabular}{|c|c|c|c|c|c|c|c|c|c|}
\hline DLBL Step & ${ }^{90} \mathrm{Sr}$ & ${ }^{106} \mathbf{R u}$ & ${ }^{110 m} \mathrm{Ag}$ & ${ }^{125} \mathrm{Sb}$ & ${ }^{134} \mathrm{Cs}$ & ${ }^{137} \mathrm{Cs}$ & ${ }^{144} \mathrm{Ce}$ & ${ }^{154} \mathbf{E u}$ & ${ }^{155} \mathbf{E u}$ \\
\hline Deconsolidation acid & $\begin{array}{c}2.13 \mathrm{E}-3 \\
(4.093)\end{array}$ & $\begin{array}{l}6.33 \mathrm{E}-3 \\
(12.148)\end{array}$ & $\begin{array}{c}<1.4 \mathrm{E}-2 \\
<(26.278)\end{array}$ & $\begin{array}{c}1.60 \mathrm{E}-4 \\
(0.308)\end{array}$ & $\begin{array}{c}3.60 \mathrm{E}-4 \\
(0.690)\end{array}$ & $\begin{array}{c}1.44 \mathrm{E}-3 \\
(2.753)\end{array}$ & $\begin{array}{c}4.93 \mathrm{E}-3 \\
(9.448)\end{array}$ & $\begin{array}{l}1.10 \mathrm{E}-3 \\
(2.119)\end{array}$ & $\begin{array}{c}1.45 \mathrm{E}-3 \\
(2.790)\end{array}$ \\
\hline Preburn leach 1 & $\begin{array}{c}2.59 \mathrm{E}-4 \\
(0.498)\end{array}$ & $\begin{array}{l}1.11 \mathrm{E}-3 \\
(2.128)\end{array}$ & $\begin{array}{c}<1.3 \mathrm{E}-2 \\
<(23.976)\end{array}$ & $\begin{array}{c}1.47 \mathrm{E}-4 \\
(0.283)\end{array}$ & $\begin{array}{c}5.39 \mathrm{E}-5 \\
(0.103)\end{array}$ & $\begin{array}{c}1.95 \mathrm{E}-4 \\
(0.374)\end{array}$ & $\begin{array}{c}9.68 \mathrm{E}-4 \\
(1.857)\end{array}$ & $\begin{array}{c}5.96 \mathrm{E}-4 \\
(1.144)\end{array}$ & $\begin{array}{c}6.16 \mathrm{E}-4 \\
(1.181)\end{array}$ \\
\hline Preburn leach 2 & $\begin{array}{c}3.83 \mathrm{E}-5 \\
(0.073)\end{array}$ & $\begin{array}{c}1.28 \mathrm{E}-4 \\
(0.246)\end{array}$ & $\begin{array}{l}<3.7 \mathrm{E}-3 \\
<(7.079)\end{array}$ & $\begin{array}{c}6.39 \mathrm{E}-5 \\
(0.123)\end{array}$ & $\begin{array}{l}3.82 \mathrm{E}-6 \\
(0.0073)\end{array}$ & $\begin{array}{c}1.54 \mathrm{E}-5 \\
(0.030)\end{array}$ & $\begin{array}{c}1.40 \mathrm{E}-4 \\
(0.269)\end{array}$ & $\begin{array}{c}7.96 \mathrm{E}-5 \\
(0.153)\end{array}$ & $\begin{array}{c}9.73 \mathrm{E}-5 \\
(0.187)\end{array}$ \\
\hline Postburn matrix leach 1 & $\begin{array}{l}1.17 \mathrm{E}-3 \\
(2.237)\end{array}$ & $\begin{array}{c}4.48 \mathrm{E}-5 \\
(0.086)\end{array}$ & $\begin{array}{c}<1.3 \mathrm{E}-2 \\
<(24.756)\end{array}$ & $\begin{array}{c}1.59 \mathrm{E}-4 \\
(0.304)\end{array}$ & $\begin{array}{c}2.70 \mathrm{E}-5 \\
(0.052)\end{array}$ & $\begin{array}{c}2.21 \mathrm{E}-4 \\
(0.424)\end{array}$ & $\begin{array}{c}9.51 \mathrm{E}-4 \\
(1.825)\end{array}$ & $\begin{array}{c}1.51 \mathrm{E}-3 \\
(2.903)\end{array}$ & $\begin{array}{l}1.49 \mathrm{E}-3 \\
(2.860)\end{array}$ \\
\hline Postburn matrix leach 2 & $\begin{array}{c}2.47 \mathrm{E}-5 \\
(0.047)\end{array}$ & $\begin{array}{c}6.97 \mathrm{E}-6 \\
(0.013)\end{array}$ & $\begin{array}{l}<1.9 \mathrm{E}-3 \\
<(3.661)\end{array}$ & $\begin{array}{l}1.22 \mathrm{E}-5 \\
(0.023)\end{array}$ & $\begin{array}{l}1.14 \mathrm{E}-6 \\
(0.0022)\end{array}$ & $\begin{array}{c}1.17 \mathrm{E}-5 \\
(0.022)\end{array}$ & $\begin{array}{c}2.48 \mathrm{E}-5 \\
(0.048)\end{array}$ & $\begin{array}{c}3.41 \mathrm{E}-5 \\
(0.065)\end{array}$ & $\begin{array}{c}3.96 \mathrm{E}-5 \\
(0.076)\end{array}$ \\
\hline Postburn particle leach $1^{a}$ & $\begin{array}{l}1.48 \mathrm{E}-3 \\
(2.841)\end{array}$ & $\begin{array}{l}<4.9 \mathrm{E}-5 \\
<(0.095)\end{array}$ & $\begin{array}{c}<1.9 \mathrm{E}-2 \\
<(35.816)\end{array}$ & $\begin{array}{l}1.24 \mathrm{E}-4 \\
(0.238)\end{array}$ & $\begin{array}{c}4.43 \mathrm{E}-6 \\
(0.0085)\end{array}$ & $\begin{array}{c}3.27 \mathrm{E}-5 \\
(0.063)\end{array}$ & $\begin{array}{c}2.44 \mathrm{E}-3 \\
(4.679)\end{array}$ & $\begin{array}{l}1.73 \mathrm{E}-3 \\
(3.314)\end{array}$ & $\begin{array}{l}1.93 \mathrm{E}-3 \\
(3.697)\end{array}$ \\
\hline Postburn particle leach $2^{a}$ & $\begin{array}{c}6.58 \mathrm{E}-5 \\
(0.126)\end{array}$ & $\begin{array}{l}<1.9 \mathrm{E}-5 \\
<(0.036)\end{array}$ & $\begin{array}{l}<3.4 \mathrm{E}-3 \\
<(6.439)\end{array}$ & $\begin{array}{c}2.13 \mathrm{E}-5 \\
(0.041)\end{array}$ & $\begin{array}{c}5.60 \mathrm{E}-6 \\
(0.011)\end{array}$ & $\begin{array}{c}7.29 \mathrm{E}-5 \\
(0.140)\end{array}$ & $\begin{array}{c}6.96 \mathrm{E}-6 \\
(0.013)\end{array}$ & $\begin{array}{l}7.12 \mathrm{E}-5 \\
(0.136)\end{array}$ & $\begin{array}{c}4.33 \mathrm{E}-5 \\
(0.083)\end{array}$ \\
\hline Total & $\begin{array}{c}5.17 \mathrm{E}-3 \\
(9.915)\end{array}$ & $\begin{array}{l}7.62 \mathrm{E}-3 \\
(14.621)\end{array}$ & $\begin{array}{c}0.00 \mathrm{E}+0 \\
(0.000)\end{array}$ & $\begin{array}{c}6.88 \mathrm{E}-4 \\
(1.320)\end{array}$ & $\begin{array}{c}4.56 \mathrm{E}-4 \\
(0.874)\end{array}$ & $\begin{array}{c}1.98 \mathrm{E}-3 \\
(3.806)\end{array}$ & $\begin{array}{l}9.46 \mathrm{E}-3 \\
(18.139)\end{array}$ & $\begin{array}{c}5.13 \mathrm{E}-3 \\
(9.834)\end{array}$ & $\begin{array}{c}5.67 \mathrm{E}-3 \\
(10.875)\end{array}$ \\
\hline
\end{tabular}

Note: Chemical separation and beta analysis were used to measure ${ }^{90} \mathrm{Sr}$; other nuclides were measured by gamma spectrometry.

Note: Values are reported as compact inventory fractions and particle equivalents (in parentheses).

Note: A less-than value indicates that the concentration in the leachate was below the minimum detectable limit; these values are not included in the totals.

${ }^{a}$ Postburn particle leach data were scaled to account for $\sim 7 \%$ particle population withheld from postburn analysis. 
Appendix Table A-15. Exposed inventory of stable nuclides of interest detected by DLBL of AGR-3/4 Compact 1-4 Segment 1

\begin{tabular}{|c|c|c|c|c|c|c|c|c|c|c|}
\hline DLBL Step & ${ }^{105} \mathbf{P d}$ & ${ }^{109} \mathrm{Ag}$ & ${ }^{133} \mathrm{Cs}$ & ${ }^{139} \mathbf{L a}$ & ${ }^{140} \mathrm{Ce}$ & ${ }^{141} \mathrm{Pr}$ & ${ }^{146} \mathrm{Nd}$ & ${ }^{152} \mathrm{Sm}$ & ${ }^{153} \mathbf{E u}$ & ${ }^{156} \mathrm{Gd}$ \\
\hline Deconsolidation acid & $\begin{array}{l}<1.5 \mathrm{E}-4 \\
<(0.280)\end{array}$ & $\begin{array}{l}1.75 \mathrm{E}-3 \\
(3.351)\end{array}$ & $\begin{array}{c}1.63 \mathrm{E}-4 \\
(0.312)\end{array}$ & $\begin{array}{c}2.30 \mathrm{E}-4 \\
(0.441)\end{array}$ & $\begin{array}{c}1.06 \mathrm{E}-4 \\
(0.203)\end{array}$ & $\begin{array}{c}5.29 \mathrm{E}-5 \\
(0.101)\end{array}$ & $\begin{array}{c}4.51 \mathrm{E}-5 \\
(0.087)\end{array}$ & $\begin{array}{l}<4.5 \mathrm{E}-5 \\
<(0.087)\end{array}$ & $\begin{array}{l}<8.7 \mathrm{E}-5 \\
<(0.166)\end{array}$ & $\begin{array}{l}<3.4 \mathrm{E}-4 \\
<(0.650)\end{array}$ \\
\hline Preburn leach 1 & $\begin{array}{c}5.74 \mathrm{E}-4 \\
(1.100)\end{array}$ & $\begin{array}{c}1.79 \mathrm{E}-3 \\
(3.436)\end{array}$ & $\begin{array}{c}8.81 \mathrm{E}-6 \\
(0.017)\end{array}$ & $\begin{array}{c}1.08 \mathrm{E}-4 \\
(0.207)\end{array}$ & $\begin{array}{c}8.54 \mathrm{E}-5 \\
(0.164)\end{array}$ & $\begin{array}{c}4.84 \mathrm{E}-6 \\
(0.0093)\end{array}$ & $\begin{array}{c}4.21 \mathrm{E}-6 \\
(0.0081)\end{array}$ & $\begin{array}{l}<2.4 \mathrm{E}-5 \\
<(0.045)\end{array}$ & $\begin{array}{l}<4.5 \mathrm{E}-5 \\
<(0.087)\end{array}$ & $\begin{array}{l}<1.8 \mathrm{E}-4 \\
<(0.340)\end{array}$ \\
\hline Preburn leach 2 & $\begin{array}{c}2.00 \mathrm{E}-4 \\
(0.384)\end{array}$ & $\begin{array}{c}4.88 \mathrm{E}-4 \\
(0.935)\end{array}$ & $\begin{array}{c}<4.3 \mathrm{E}-6 \\
<(0.0082)\end{array}$ & $\begin{array}{c}1.38 \mathrm{E}-5 \\
(0.026)\end{array}$ & $\begin{array}{c}1.40 \mathrm{E}-5 \\
(0.027)\end{array}$ & $\begin{array}{l}<4.6 \mathrm{E}-6 \\
<(0.0087)\end{array}$ & $\begin{array}{l}<7.2 \mathrm{E}-6 \\
<(0.014)\end{array}$ & $\begin{array}{l}<4.3 \mathrm{E}-5 \\
<(0.082)\end{array}$ & $\begin{array}{l}<8.2 \mathrm{E}-5 \\
<(0.157)\end{array}$ & $\begin{array}{l}<3.2 \mathrm{E}-4 \\
<(0.615)\end{array}$ \\
\hline Postburn matrix leach 1 & $\begin{array}{c}1.86 \mathrm{E}-4 \\
(0.356)\end{array}$ & $\begin{array}{c}2.33 \mathrm{E}-3 \\
(4.473)\end{array}$ & $\begin{array}{c}2.52 \mathrm{E}-5 \\
(0.048)\end{array}$ & $\begin{array}{c}2.16 \mathrm{E}-4 \\
(0.414)\end{array}$ & $\begin{array}{c}3.86 \mathrm{E}-4 \\
(0.741)\end{array}$ & $\begin{array}{c}8.16 \mathrm{E}-5 \\
(0.157)\end{array}$ & $\begin{array}{c}8.68 \mathrm{E}-5 \\
(0.167)\end{array}$ & $\begin{array}{c}9.47 \mathrm{E}-5 \\
(0.182)\end{array}$ & $\begin{array}{c}3.16 \mathrm{E}-4 \\
(0.607)\end{array}$ & $\begin{array}{l}1.50 \mathrm{E}-3 \\
(2.872)\end{array}$ \\
\hline Postburn matrix leach 2 & $\begin{array}{l}<5.7 \mathrm{E}-5 \\
<(0.110)\end{array}$ & $\begin{array}{c}6.85 \mathrm{E}-4 \\
(1.314)\end{array}$ & $\begin{array}{c}1.97 \mathrm{E}-6 \\
(0.0038)\end{array}$ & $\begin{array}{c}4.56 \mathrm{E}-6 \\
(0.0087)\end{array}$ & $\begin{array}{c}2.61 \mathrm{E}-5 \\
(0.050)\end{array}$ & $\begin{array}{l}<1.9 \mathrm{E}-6 \\
<(0.0036)\end{array}$ & $\begin{array}{c}<3.0 \mathrm{E}-6 \\
<(0.0057)\end{array}$ & $\begin{array}{l}<1.8 \mathrm{E}-5 \\
<(0.034)\end{array}$ & $\begin{array}{l}<3.4 \mathrm{E}-5 \\
<(0.065)\end{array}$ & $\begin{array}{l}<1.3 \mathrm{E}-4 \\
<(0.256)\end{array}$ \\
\hline Postburn particle leach $1^{a}$ & $\begin{array}{l}<1.5 \mathrm{E}-4 \\
<(0.289)\end{array}$ & $\begin{array}{c}3.47 \mathrm{E}-3 \\
(6.664)\end{array}$ & $\begin{array}{c}4.07 \mathrm{E}-4 \\
(0.780)\end{array}$ & $\begin{array}{c}3.04 \mathrm{E}-4 \\
(0.583)\end{array}$ & $\begin{array}{c}8.20 \mathrm{E}-4 \\
(1.573)\end{array}$ & $\begin{array}{c}6.23 \mathrm{E}-4 \\
(1.195)\end{array}$ & $\begin{array}{c}5.22 \mathrm{E}-4 \\
(1.001)\end{array}$ & $\begin{array}{c}5.81 \mathrm{E}-4 \\
(1.115)\end{array}$ & $\begin{array}{c}8.09 \mathrm{E}-4 \\
(1.552)\end{array}$ & $\begin{array}{c}2.29 \mathrm{E}-3 \\
(4.393)\end{array}$ \\
\hline Postburn particle leach $2^{a}$ & $\begin{array}{l}<1.3 \mathrm{E}-4 \\
<(0.258)\end{array}$ & $\begin{array}{c}9.37 \mathrm{E}-4 \\
(1.797)\end{array}$ & $\begin{array}{c}2.37 \mathrm{E}-5 \\
(0.045)\end{array}$ & $\begin{array}{c}6.03 \mathrm{E}-6 \\
(0.012)\end{array}$ & $\begin{array}{c}1.27 \mathrm{E}-4 \\
(0.244)\end{array}$ & $\begin{array}{c}1.06 \mathrm{E}-5 \\
(0.020)\end{array}$ & $\begin{array}{l}1.03 \mathrm{E}-5 \\
(0.020)\end{array}$ & $\begin{array}{l}<4.2 \mathrm{E}-5 \\
<(0.080)\end{array}$ & $\begin{array}{l}<8.0 \mathrm{E}-5 \\
<(0.153)\end{array}$ & $\begin{array}{l}<3.1 \mathrm{E}-4 \\
<(0.600)\end{array}$ \\
\hline Total & $\begin{array}{c}9.60 \mathrm{E}-4 \\
(1.840)\end{array}$ & $\begin{array}{c}1.15 \mathrm{E}-2 \\
(21.969)\end{array}$ & $\begin{array}{c}6.29 \mathrm{E}-4 \\
(1.206)\end{array}$ & $\begin{array}{c}8.82 \mathrm{E}-4 \\
(1.692)\end{array}$ & $\begin{array}{c}1.57 \mathrm{E}-3 \\
(3.002)\end{array}$ & $\begin{array}{c}7.73 \mathrm{E}-4 \\
(1.483)\end{array}$ & $\begin{array}{c}6.69 \mathrm{E}-4 \\
(1.282)\end{array}$ & $\begin{array}{c}6.76 \mathrm{E}-4 \\
(1.297)\end{array}$ & $\begin{array}{c}1.13 \mathrm{E}-3 \\
(2.159)\end{array}$ & $\begin{array}{c}3.79 \mathrm{E}-3 \\
(7.265)\end{array}$ \\
\hline
\end{tabular}

Note: Values are reported as compact inventory fractions and particle equivalents (in parentheses).

Note: A less-than value indicates that the concentration in the leachate was below the minimum detectable limit; these values are not included in the totals.

${ }^{a}$ Because of the presence of an exposed kernel in the first postburn particle leach, no scaling factor was applied to account for $\sim 11 \%$ particle population withheld from postburn analysis. 
Appendix Table A-16. Exposed inventory of stable nuclides of interest detected by DLBL of AGR-3/4 Compact 1-4 Segment 2

\begin{tabular}{|c|c|c|c|c|c|c|c|c|c|c|}
\hline DLBL Step & ${ }^{105} \mathrm{Pd}$ & ${ }^{109} \mathrm{Ag}$ & ${ }^{133} \mathrm{Cs}$ & ${ }^{139} \mathbf{L a}$ & ${ }^{140} \mathrm{Ce}$ & ${ }^{141} \operatorname{Pr}$ & ${ }^{146} \mathrm{Nd}$ & ${ }^{152} \mathrm{Sm}$ & ${ }^{153} \mathbf{E u}$ & ${ }^{156} \mathrm{Gd}$ \\
\hline Deconsolidation acid & $\begin{array}{l}<1.2 \mathrm{E}-4 \\
<(0.236)\end{array}$ & $\begin{array}{c}4.62 \mathrm{E}-3 \\
(8.866)\end{array}$ & $\begin{array}{c}6.30 \mathrm{E}-4 \\
(1.209)\end{array}$ & $\begin{array}{c}4.78 \mathrm{E}-4 \\
(0.917)\end{array}$ & $\begin{array}{c}3.86 \mathrm{E}-4 \\
(0.741)\end{array}$ & $\begin{array}{c}3.72 \mathrm{E}-4 \\
(0.713)\end{array}$ & $\begin{array}{c}3.25 \mathrm{E}-4 \\
(0.623)\end{array}$ & $\begin{array}{c}3.58 \mathrm{E}-4 \\
(0.687)\end{array}$ & $\begin{array}{c}3.64 \mathrm{E}-4 \\
(0.698)\end{array}$ & $\begin{array}{l}1.07 \mathrm{E}-3 \\
(2.058)\end{array}$ \\
\hline Preburn leach 1 & $\begin{array}{l}<1.1 \mathrm{E}-4 \\
<(0.201)\end{array}$ & $\begin{array}{c}5.00 \mathrm{E}-4 \\
(0.958)\end{array}$ & $\begin{array}{c}5.10 \mathrm{E}-6 \\
(0.0098)\end{array}$ & $\begin{array}{c}9.76 \mathrm{E}-5 \\
(0.187)\end{array}$ & $\begin{array}{c}9.02 \mathrm{E}-5 \\
(0.173)\end{array}$ & $\begin{array}{c}6.02 \mathrm{E}-6 \\
(0.012)\end{array}$ & $\begin{array}{l}<5.5 \mathrm{E}-6 \\
<(0.010)\end{array}$ & $\begin{array}{l}<3.3 \mathrm{E}-5 \\
<(0.062)\end{array}$ & $\begin{array}{l}<6.2 \mathrm{E}-5 \\
<(0.120)\end{array}$ & $\begin{array}{l}<2.4 \mathrm{E}-4 \\
<(0.467)\end{array}$ \\
\hline Preburn leach 2 & $\begin{array}{l}<1.7 \mathrm{E}-4 \\
<(0.322)\end{array}$ & $\begin{array}{c}4.07 \mathrm{E}-4 \\
(0.780)\end{array}$ & $\begin{array}{l}<5.2 \mathrm{E}-6 \\
<(0.010)\end{array}$ & $\begin{array}{l}1.45 \mathrm{E}-5 \\
(0.028)\end{array}$ & $\begin{array}{c}3.13 \mathrm{E}-5 \\
(0.060)\end{array}$ & $\begin{array}{l}<5.5 \mathrm{E}-6 \\
<(0.011)\end{array}$ & $\begin{array}{l}<8.7 \mathrm{E}-6 \\
<(0.017)\end{array}$ & $\begin{array}{l}<5.2 \mathrm{E}-5 \\
<(0.100)\end{array}$ & $\begin{array}{l}<1.0 \mathrm{E}-4 \\
<(0.191)\end{array}$ & $\begin{array}{l}<3.9 \mathrm{E}-4 \\
<(0.747)\end{array}$ \\
\hline Postburn matrix leach 1 & $\begin{array}{c}3.53 \mathrm{E}-4 \\
(0.677)\end{array}$ & $\begin{array}{l}6.14 \mathrm{E}-3 \\
(11.774)\end{array}$ & $\begin{array}{c}3.65 \mathrm{E}-5 \\
(0.070)\end{array}$ & $\begin{array}{c}3.54 \mathrm{E}-4 \\
(0.679)\end{array}$ & $\begin{array}{c}6.51 \mathrm{E}-4 \\
(1.249)\end{array}$ & $\begin{array}{c}1.32 \mathrm{E}-4 \\
(0.253)\end{array}$ & $\begin{array}{c}1.36 \mathrm{E}-4 \\
(0.260)\end{array}$ & $\begin{array}{c}1.47 \mathrm{E}-4 \\
(0.282)\end{array}$ & $\begin{array}{c}4.73 \mathrm{E}-4 \\
(0.907)\end{array}$ & $\begin{array}{c}2.23 \mathrm{E}-3 \\
(4.277)\end{array}$ \\
\hline Postburn matrix leach 2 & $\begin{array}{l}<5.9 \mathrm{E}-5 \\
<(0.113)\end{array}$ & $\begin{array}{l}1.10 \mathrm{E}-3 \\
(2.112)\end{array}$ & $\begin{array}{l}1.44 \mathrm{E}-5 \\
(0.028)\end{array}$ & $\begin{array}{l}1.70 \mathrm{E}-5 \\
(0.033)\end{array}$ & $\begin{array}{c}5.00 \mathrm{E}-5 \\
(0.096)\end{array}$ & $\begin{array}{c}6.68 \mathrm{E}-6 \\
(0.013)\end{array}$ & $\begin{array}{c}7.19 \mathrm{E}-6 \\
(0.014)\end{array}$ & $\begin{array}{l}<1.8 \mathrm{E}-5 \\
<(0.035)\end{array}$ & $\begin{array}{l}<3.5 \mathrm{E}-5 \\
<(0.067)\end{array}$ & $\begin{array}{l}<1.4 \mathrm{E}-4 \\
<(0.261)\end{array}$ \\
\hline Postburn particle leach $1^{a}$ & $\begin{array}{l}<1.8 \mathrm{E}-4 \\
<(0.345)\end{array}$ & $\begin{array}{c}2.62 \mathrm{E}-3 \\
(5.034)\end{array}$ & $\begin{array}{c}1.11 \mathrm{E}-4 \\
(0.213)\end{array}$ & $\begin{array}{c}7.35 \mathrm{E}-5 \\
(0.141)\end{array}$ & $\begin{array}{c}2.67 \mathrm{E}-4 \\
(0.512)\end{array}$ & $\begin{array}{c}1.27 \mathrm{E}-4 \\
(0.243)\end{array}$ & $\begin{array}{c}1.26 \mathrm{E}-4 \\
(0.242)\end{array}$ & $\begin{array}{c}9.19 \mathrm{E}-5 \\
(0.176)\end{array}$ & $\begin{array}{c}3.28 \mathrm{E}-4 \\
(0.629)\end{array}$ & $\begin{array}{l}1.50 \mathrm{E}-3 \\
(2.881)\end{array}$ \\
\hline Postburn particle leach $2^{a}$ & $\begin{array}{l}<1.9 \mathrm{E}-4 \\
<(0.360)\end{array}$ & $\begin{array}{c}3.91 \mathrm{E}-4 \\
(0.750)\end{array}$ & $\begin{array}{c}1.13 \mathrm{E}-5 \\
(0.022)\end{array}$ & $\begin{array}{l}<5.7 \mathrm{E}-6 \\
<(0.011)\end{array}$ & $\begin{array}{l}1.18 \mathrm{E}-4 \\
(0.227)\end{array}$ & $\begin{array}{l}<6.2 \mathrm{E}-6 \\
<(0.012)\end{array}$ & $\begin{array}{l}<9.7 \mathrm{E}-6 \\
<(0.019)\end{array}$ & $\begin{array}{l}<5.8 \mathrm{E}-5 \\
<(0.112)\end{array}$ & $\begin{array}{l}<1.1 \mathrm{E}-4 \\
<(0.214)\end{array}$ & $\begin{array}{l}<4.4 \mathrm{E}-4 \\
<(0.836)\end{array}$ \\
\hline Total & $\begin{array}{c}3.53 \mathrm{E}-4 \\
(0.677)\end{array}$ & $\begin{array}{c}1.58 \mathrm{E}-2 \\
(30.273)\end{array}$ & $\begin{array}{c}8.08 \mathrm{E}-4 \\
(1.550)\end{array}$ & $\begin{array}{c}1.03 \mathrm{E}-3 \\
(1.984)\end{array}$ & $\begin{array}{c}1.59 \mathrm{E}-3 \\
(3.057)\end{array}$ & $\begin{array}{c}6.43 \mathrm{E}-4 \\
(1.233)\end{array}$ & $\begin{array}{c}5.94 \mathrm{E}-4 \\
(1.139)\end{array}$ & $\begin{array}{c}5.97 \mathrm{E}-4 \\
(1.145)\end{array}$ & $\begin{array}{l}1.16 \mathrm{E}-3 \\
(2.234)\end{array}$ & $\begin{array}{c}4.80 \mathrm{E}-3 \\
(9.215)\end{array}$ \\
\hline
\end{tabular}

Note: Values are reported as compact inventory fractions and particle equivalents (in parentheses).

Note: A less-than value indicates that the concentration in the leachate was below the minimum detectable limit; these values are not included in the totals.

${ }^{a}$ Postburn particle leach data were scaled to account for $\sim 14 \%$ particle population withheld from postburn analysis. 
Appendix Table A-17. Exposed inventory of stable nuclides of interest detected by DLBL of AGR-3/4 Compact 1-4 Segment 3

\begin{tabular}{|c|c|c|c|c|c|c|c|c|c|c|}
\hline DLBL Step & ${ }^{105} \mathrm{Pd}$ & ${ }^{109} \mathrm{Ag}$ & ${ }^{133} \mathrm{Cs}$ & ${ }^{139} \mathbf{L a}$ & ${ }^{140} \mathrm{Ce}$ & ${ }^{141} \mathrm{Pr}$ & ${ }^{146} \mathrm{Nd}$ & ${ }^{152} \mathrm{Sm}$ & ${ }^{153} \mathbf{E u}$ & ${ }^{156} \mathbf{G d}$ \\
\hline Deconsolidation acid & $\begin{array}{l}<1.2 \mathrm{E}-4 \\
<(0.234)\end{array}$ & $\begin{array}{l}1.78 \mathrm{E}-3 \\
(3.420)\end{array}$ & $\begin{array}{c}1.03 \mathrm{E}-3 \\
(1.968)\end{array}$ & $\begin{array}{c}6.86 \mathrm{E}-4 \\
(1.315)\end{array}$ & $\begin{array}{c}5.44 \mathrm{E}-4 \\
(1.043)\end{array}$ & $\begin{array}{c}5.72 \mathrm{E}-4 \\
(1.096)\end{array}$ & $\begin{array}{c}5.03 \mathrm{E}-4 \\
(0.964)\end{array}$ & $\begin{array}{c}5.56 \mathrm{E}-4 \\
(1.067)\end{array}$ & $\begin{array}{c}5.78 \mathrm{E}-4 \\
(1.109)\end{array}$ & $\begin{array}{l}1.37 \mathrm{E}-3 \\
(2.623)\end{array}$ \\
\hline Preburn leach 1 & $\begin{array}{l}<1.6 \mathrm{E}-4 \\
<(0.315)\end{array}$ & $\begin{array}{c}2.11 \mathrm{E}-3 \\
(4.039)\end{array}$ & $\begin{array}{c}8.80 \mathrm{E}-6 \\
(0.017)\end{array}$ & $\begin{array}{c}4.07 \mathrm{E}-5 \\
(0.078)\end{array}$ & $\begin{array}{c}6.09 \mathrm{E}-5 \\
(0.117)\end{array}$ & $\begin{array}{c}1.03 \mathrm{E}-5 \\
(0.020)\end{array}$ & $\begin{array}{c}1.02 \mathrm{E}-5 \\
(0.020)\end{array}$ & $\begin{array}{l}<5.1 \mathrm{E}-5 \\
<(0.098)\end{array}$ & $\begin{array}{l}<9.8 \mathrm{E}-5 \\
<(0.187)\end{array}$ & $\begin{array}{l}<3.8 \mathrm{E}-4 \\
<(0.732)\end{array}$ \\
\hline Preburn leach 2 & $\begin{array}{c}2.34 \mathrm{E}-4 \\
(0.449)\end{array}$ & $\begin{array}{l}1.19 \mathrm{E}-3 \\
(2.278)\end{array}$ & $\begin{array}{c}4.38 \mathrm{E}-5 \\
(0.084)\end{array}$ & $\begin{array}{c}1.25 \mathrm{E}-4 \\
(0.239)\end{array}$ & $\begin{array}{c}2.87 \mathrm{E}-4 \\
(0.550)\end{array}$ & $\begin{array}{c}2.76 \mathrm{E}-5 \\
(0.053)\end{array}$ & $\begin{array}{c}3.38 \mathrm{E}-5 \\
(0.065)\end{array}$ & $\begin{array}{l}1.06 \mathrm{E}-3 \\
(2.028)\end{array}$ & $\begin{array}{c}2.54 \mathrm{E}-3 \\
(4.869)\end{array}$ & $\begin{array}{c}7.78 \mathrm{E}-4 \\
(1.492)\end{array}$ \\
\hline Postburn matrix leach 1 & $\begin{array}{l}<7.5 \mathrm{E}-5 \\
<(0.144)\end{array}$ & $\begin{array}{l}5.63 \mathrm{E}-3 \\
(10.804)\end{array}$ & $\begin{array}{c}3.76 \mathrm{E}-5 \\
(0.072)\end{array}$ & $\begin{array}{c}1.44 \mathrm{E}-4 \\
(0.277)\end{array}$ & $\begin{array}{c}2.71 \mathrm{E}-4 \\
(0.520)\end{array}$ & $\begin{array}{l}7.03 \mathrm{E}-5 \\
(0.135)\end{array}$ & $\begin{array}{c}7.33 \mathrm{E}-5 \\
(0.141)\end{array}$ & $\begin{array}{c}7.25 \mathrm{E}-5 \\
(0.139)\end{array}$ & $\begin{array}{c}3.35 \mathrm{E}-4 \\
(0.643)\end{array}$ & $\begin{array}{l}1.09 \mathrm{E}-3 \\
(2.091)\end{array}$ \\
\hline Postburn matrix leach 2 & $\begin{array}{l}<7.4 \mathrm{E}-5 \\
<(0.141)\end{array}$ & $\begin{array}{l}1.23 \mathrm{E}-3 \\
(2.356)\end{array}$ & $\begin{array}{c}6.65 \mathrm{E}-6 \\
(0.013)\end{array}$ & $\begin{array}{l}1.33 \mathrm{E}-5 \\
(0.025)\end{array}$ & $\begin{array}{c}3.88 \mathrm{E}-5 \\
(0.074)\end{array}$ & $\begin{array}{c}6.86 \mathrm{E}-6 \\
(0.013)\end{array}$ & $\begin{array}{c}6.77 \mathrm{E}-6 \\
(0.013)\end{array}$ & $\begin{array}{l}<2.3 \mathrm{E}-5 \\
<(0.044)\end{array}$ & $\begin{array}{l}<4.4 \mathrm{E}-5 \\
<(0.084)\end{array}$ & $\begin{array}{l}<1.7 \mathrm{E}-4 \\
<(0.328)\end{array}$ \\
\hline Postburn particle leach $1^{a}$ & $\begin{array}{l}<1.5 \mathrm{E}-4 \\
<(0.285)\end{array}$ & $\begin{array}{c}2.20 \mathrm{E}-3 \\
(4.225)\end{array}$ & $\begin{array}{c}3.30 \mathrm{E}-5 \\
(0.063)\end{array}$ & $\begin{array}{c}2.10 \mathrm{E}-5 \\
(0.040)\end{array}$ & $\begin{array}{c}1.26 \mathrm{E}-4 \\
(0.242)\end{array}$ & $\begin{array}{c}3.61 \mathrm{E}-5 \\
(0.069)\end{array}$ & $\begin{array}{c}3.60 \mathrm{E}-5 \\
(0.069)\end{array}$ & $\begin{array}{l}<4.6 \mathrm{E}-5 \\
<(0.088)\end{array}$ & $\begin{array}{c}1.59 \mathrm{E}-4 \\
(0.306)\end{array}$ & $\begin{array}{c}5.48 \mathrm{E}-4 \\
(1.050)\end{array}$ \\
\hline Postburn particle leach $2^{a}$ & $\begin{array}{l}<1.4 \mathrm{E}-4 \\
<(0.276)\end{array}$ & $\begin{array}{c}7.49 \mathrm{E}-4 \\
(1.436)\end{array}$ & $\begin{array}{c}2.27 \mathrm{E}-5 \\
(0.044)\end{array}$ & $\begin{array}{l}1.13 \mathrm{E}-5 \\
(0.022)\end{array}$ & $\begin{array}{l}1.17 \mathrm{E}-4 \\
(0.224)\end{array}$ & $\begin{array}{c}1.87 \mathrm{E}-5 \\
(0.036)\end{array}$ & $\begin{array}{l}1.94 \mathrm{E}-5 \\
(0.037)\end{array}$ & $\begin{array}{l}<4.5 \mathrm{E}-5 \\
<(0.086)\end{array}$ & $\begin{array}{l}<8.5 \mathrm{E}-5 \\
<(0.164)\end{array}$ & $\begin{array}{c}3.71 \mathrm{E}-4 \\
(0.711)\end{array}$ \\
\hline Total & $\begin{array}{c}2.34 \mathrm{E}-4 \\
(0.449)\end{array}$ & $\begin{array}{c}1.49 \mathrm{E}-2 \\
(28.558)\end{array}$ & $\begin{array}{c}1.18 \mathrm{E}-3 \\
(2.261)\end{array}$ & $\begin{array}{l}1.04 \mathrm{E}-3 \\
(1.997)\end{array}$ & $\begin{array}{l}1.44 \mathrm{E}-3 \\
(2.771)\end{array}$ & $\begin{array}{l}7.42 \mathrm{E}-4 \\
(1.422)\end{array}$ & $\begin{array}{c}6.82 \mathrm{E}-4 \\
(1.308)\end{array}$ & $\begin{array}{c}1.69 \mathrm{E}-3 \\
(3.235)\end{array}$ & $\begin{array}{c}3.61 \mathrm{E}-3 \\
(6.927)\end{array}$ & $\begin{array}{c}4.15 \mathrm{E}-3 \\
(7.968)\end{array}$ \\
\hline
\end{tabular}

Note: Values are reported as compact inventory fractions and particle equivalents (in parentheses).

Note: A less-than value indicates that the concentration in the leachate was below the minimum detectable limit; these values are not included in the totals.

${ }^{a}$ Because most of the particles deconsolidated from Segment 3 were lost when sieve stack was knocked over, only $2 \%$ of the particles were included in postburn particle leach and data were not scaled. 
Appendix Table A-18. Exposed inventory of stable nuclides of interest detected by DLBL of AGR-3/4 Compact 1-4 Segment 4

\begin{tabular}{|c|c|c|c|c|c|c|c|c|c|c|}
\hline DLBL Step & ${ }^{105} \mathrm{Pd}$ & ${ }^{109} \mathrm{Ag}$ & ${ }^{133} \mathrm{Cs}$ & ${ }^{139} \mathbf{L a}$ & ${ }^{140} \mathrm{Ce}$ & ${ }^{141} \mathrm{Pr}$ & ${ }^{146} \mathrm{Nd}$ & ${ }^{152} \mathrm{Sm}$ & ${ }^{153} \mathbf{E u}$ & ${ }^{156} \mathbf{G d}$ \\
\hline Deconsolidation acid & $\begin{array}{c}1.64 \mathrm{E}-4 \\
(0.314)\end{array}$ & $\begin{array}{c}7.43 \mathrm{E}-3 \\
(14.248)\end{array}$ & $\begin{array}{c}6.47 \mathrm{E}-3 \\
(12.416)\end{array}$ & $\begin{array}{c}8.97 \mathrm{E}-3 \\
(17.210)\end{array}$ & $\begin{array}{l}9.07 \mathrm{E}-3 \\
(17.398)\end{array}$ & $\begin{array}{c}8.98 \mathrm{E}-3 \\
(17.230)\end{array}$ & $\begin{array}{c}7.64 \mathrm{E}-3 \\
(14.651)\end{array}$ & $\begin{array}{c}8.21 \mathrm{E}-3 \\
(15.749)\end{array}$ & $\begin{array}{c}7.57 \mathrm{E}-3 \\
(14.522)\end{array}$ & $\begin{array}{c}1.87 \mathrm{E}-2 \\
(35.817)\end{array}$ \\
\hline Preburn leach 1 & $\begin{array}{l}<1.4 \mathrm{E}-4 \\
<(0.276)\end{array}$ & $\begin{array}{c}2.53 \mathrm{E}-3 \\
(4.847)\end{array}$ & $\begin{array}{c}7.78 \mathrm{E}-4 \\
(1.492)\end{array}$ & $\begin{array}{c}1.13 \mathrm{E}-4 \\
(0.217)\end{array}$ & $\begin{array}{c}2.76 \mathrm{E}-4 \\
(0.530)\end{array}$ & $\begin{array}{c}6.45 \mathrm{E}-5 \\
(0.124)\end{array}$ & $\begin{array}{c}5.41 \mathrm{E}-5 \\
(0.104)\end{array}$ & $\begin{array}{c}6.20 \mathrm{E}-5 \\
(0.119)\end{array}$ & $\begin{array}{c}1.02 \mathrm{E}-4 \\
(0.196)\end{array}$ & $\begin{array}{c}5.21 \mathrm{E}-4 \\
(0.999)\end{array}$ \\
\hline Preburn leach 2 & $\begin{array}{l}<1.6 \mathrm{E}-4 \\
<(0.298)\end{array}$ & $\begin{array}{c}6.94 \mathrm{E}-4 \\
(1.332)\end{array}$ & $\begin{array}{c}6.69 \mathrm{E}-5 \\
(0.128)\end{array}$ & $\begin{array}{c}4.32 \mathrm{E}-5 \\
(0.083)\end{array}$ & $\begin{array}{c}1.39 \mathrm{E}-4 \\
(0.267)\end{array}$ & $\begin{array}{c}2.98 \mathrm{E}-5 \\
(0.057)\end{array}$ & $\begin{array}{c}2.44 \mathrm{E}-5 \\
(0.047)\end{array}$ & $\begin{array}{l}<4.8 \mathrm{E}-5 \\
<(0.092)\end{array}$ & $\begin{array}{l}<9.2 \mathrm{E}-5 \\
<(0.177)\end{array}$ & $\begin{array}{l}<3.6 \mathrm{E}-4 \\
<(0.691)\end{array}$ \\
\hline Postburn matrix leach 1 & $\begin{array}{c}1.61 \mathrm{E}-3 \\
(3.083)\end{array}$ & $\begin{array}{c}9.02 \mathrm{E}-3 \\
(17.305)\end{array}$ & $\begin{array}{c}7.75 \mathrm{E}-5 \\
(0.149)\end{array}$ & $\begin{array}{c}2.44 \mathrm{E}-4 \\
(0.468)\end{array}$ & $\begin{array}{c}3.09 \mathrm{E}-4 \\
(0.593)\end{array}$ & $\begin{array}{c}1.36 \mathrm{E}-4 \\
(0.261)\end{array}$ & $\begin{array}{c}1.19 \mathrm{E}-4 \\
(0.228)\end{array}$ & $\begin{array}{c}1.22 \mathrm{E}-4 \\
(0.234)\end{array}$ & $\begin{array}{c}4.53 \mathrm{E}-4 \\
(0.870)\end{array}$ & $\begin{array}{l}1.14 \mathrm{E}-3 \\
(2.181)\end{array}$ \\
\hline Postburn matrix leach 2 & $\begin{array}{l}<7.8 \mathrm{E}-5 \\
<(0.150)\end{array}$ & $\begin{array}{c}3.66 \mathrm{E}-4 \\
(0.702)\end{array}$ & $\begin{array}{c}4.56 \mathrm{E}-6 \\
(0.0087)\end{array}$ & $\begin{array}{c}8.99 \mathrm{E}-6 \\
(0.017)\end{array}$ & $\begin{array}{c}2.78 \mathrm{E}-5 \\
(0.053)\end{array}$ & $\begin{array}{c}3.84 \mathrm{E}-6 \\
(0.0074)\end{array}$ & $\begin{array}{c}<4.1 \mathrm{E}-6 \\
<(0.0078)\end{array}$ & $\begin{array}{l}<2.4 \mathrm{E}-5 \\
<(0.047)\end{array}$ & $\begin{array}{l}<4.6 \mathrm{E}-5 \\
<(0.089)\end{array}$ & $\begin{array}{l}<1.8 \mathrm{E}-4 \\
<(0.349)\end{array}$ \\
\hline Postburn particle leach $1^{a}$ & $\begin{array}{c}2.60 \mathrm{E}-3 \\
(4.996)\end{array}$ & $\begin{array}{c}7.18 \mathrm{E}-4 \\
(1.378)\end{array}$ & $\begin{array}{c}8.48 \mathrm{E}-5 \\
(0.163)\end{array}$ & $\begin{array}{c}1.49 \mathrm{E}-4 \\
(0.287)\end{array}$ & $\begin{array}{c}5.60 \mathrm{E}-4 \\
(1.075)\end{array}$ & $\begin{array}{c}3.17 \mathrm{E}-4 \\
(0.609)\end{array}$ & $\begin{array}{c}2.57 \mathrm{E}-4 \\
(0.492)\end{array}$ & $\begin{array}{c}4.41 \mathrm{E}-4 \\
(0.846)\end{array}$ & $\begin{array}{c}4.62 \mathrm{E}-4 \\
(0.885)\end{array}$ & $\begin{array}{l}1.37 \mathrm{E}-3 \\
(2.621)\end{array}$ \\
\hline Postburn particle leach $2^{a}$ & $\begin{array}{l}<1.6 \mathrm{E}-4 \\
<(0.310)\end{array}$ & $\begin{array}{c}7.37 \mathrm{E}-4 \\
(1.413)\end{array}$ & $\begin{array}{c}2.74 \mathrm{E}-5 \\
(0.053)\end{array}$ & $\begin{array}{c}7.09 \mathrm{E}-6 \\
(0.014)\end{array}$ & $\begin{array}{c}1.19 \mathrm{E}-4 \\
(0.227)\end{array}$ & $\begin{array}{l}1.13 \mathrm{E}-5 \\
(0.022)\end{array}$ & $\begin{array}{l}1.22 \mathrm{E}-5 \\
(0.023)\end{array}$ & $\begin{array}{l}<5.0 \mathrm{E}-5 \\
<(0.096)\end{array}$ & $\begin{array}{l}<9.6 \mathrm{E}-5 \\
<(0.184)\end{array}$ & $\begin{array}{l}<3.8 \mathrm{E}-4 \\
<(0.720)\end{array}$ \\
\hline Total & $\begin{array}{c}4.38 \mathrm{E}-3 \\
(8.393)\end{array}$ & $\begin{array}{l}2.15 \mathrm{E}-2 \\
(41.225)\end{array}$ & $\begin{array}{c}7.51 \mathrm{E}-3 \\
(14.409)\end{array}$ & $\begin{array}{l}9.54 \mathrm{E}-3 \\
(18.295)\end{array}$ & $\begin{array}{c}1.05 \mathrm{E}-2 \\
(20.144)\end{array}$ & $\begin{array}{c}9.55 \mathrm{E}-3 \\
(18.309)\end{array}$ & $\begin{array}{c}8.11 \mathrm{E}-3 \\
(15.546)\end{array}$ & $\begin{array}{c}8.84 \mathrm{E}-3 \\
(16.948)\end{array}$ & $\begin{array}{c}8.59 \mathrm{E}-3 \\
(16.473)\end{array}$ & $\begin{array}{c}2.17 \mathrm{E}-2 \\
(41.618)\end{array}$ \\
\hline
\end{tabular}

Note: Values are reported as compact inventory fractions and particle equivalents (in parentheses).

Note: A less-than value indicates that the concentration in the leachate was below the minimum detectable limit; these values are not included in the totals.

${ }^{a}$ Postburn particle leach data were scaled to account for $\sim 15 \%$ particle population withheld from postburn analysis. 
Appendix Table A-19. Exposed inventory of stable nuclides of interest detected by DLBL of AGR-3/4 Compact 10-4 Segment 1

\begin{tabular}{|c|c|c|c|c|c|c|c|c|c|c|}
\hline DLBL Step & ${ }^{105} \mathrm{Pd}$ & ${ }^{109} \mathrm{Ag}$ & ${ }^{133} \mathrm{Cs}$ & ${ }^{139} \mathbf{L a}$ & ${ }^{140} \mathrm{Ce}$ & ${ }^{141} \mathrm{Pr}$ & ${ }^{146} \mathrm{Nd}$ & ${ }^{152} \mathrm{Sm}$ & ${ }^{153} \mathbf{E u}$ & ${ }^{156} \mathbf{G d}$ \\
\hline Deconsolidation acid & $\begin{array}{l}<8.1 \mathrm{E}-5 \\
<(0.156)\end{array}$ & $\begin{array}{l}1.53 \mathrm{E}-3 \\
(2.937)\end{array}$ & $\begin{array}{c}3.07 \mathrm{E}-5 \\
(0.059)\end{array}$ & $\begin{array}{c}6.28 \mathrm{E}-5 \\
(0.120)\end{array}$ & $\begin{array}{c}4.43 \mathrm{E}-5 \\
(0.085)\end{array}$ & $\begin{array}{c}3.05 \mathrm{E}-5 \\
(0.058)\end{array}$ & $\begin{array}{c}3.22 \mathrm{E}-5 \\
(0.062)\end{array}$ & $\begin{array}{c}4.71 \mathrm{E}-5 \\
(0.090)\end{array}$ & $\begin{array}{c}2.35 \mathrm{E}-4 \\
(0.450)\end{array}$ & $\begin{array}{c}2.89 \mathrm{E}-4 \\
(0.553)\end{array}$ \\
\hline Preburn leach 1 & $\begin{array}{l}<7.3 \mathrm{E}-5 \\
<(0.141)\end{array}$ & $\begin{array}{c}3.95 \mathrm{E}-4 \\
(0.757)\end{array}$ & $\begin{array}{c}9.62 \mathrm{E}-6 \\
(0.018)\end{array}$ & $\begin{array}{c}3.18 \mathrm{E}-5 \\
(0.061)\end{array}$ & $\begin{array}{c}1.13 \mathrm{E}-4 \\
(0.217)\end{array}$ & $\begin{array}{l}4.94 \mathrm{E}-6 \\
(0.0095)\end{array}$ & $\begin{array}{c}4.25 \mathrm{E}-6 \\
(0.0082)\end{array}$ & $\begin{array}{l}<2.6 \mathrm{E}-5 \\
<(0.049)\end{array}$ & $\begin{array}{c}7.93 \mathrm{E}-5 \\
(0.152)\end{array}$ & $\begin{array}{c}1.43 \mathrm{E}-4 \\
(0.274)\end{array}$ \\
\hline Preburn leach 2 & $\begin{array}{l}<7.6 \mathrm{E}-5 \\
<(0.146)\end{array}$ & $\begin{array}{c}3.13 \mathrm{E}-4 \\
(0.601)\end{array}$ & $\begin{array}{l}4.80 \mathrm{E}-6 \\
(0.0092)\end{array}$ & $\begin{array}{c}8.02 \mathrm{E}-6 \\
(0.015)\end{array}$ & $\begin{array}{c}6.55 \mathrm{E}-5 \\
(0.126)\end{array}$ & $\begin{array}{c}<2.7 \mathrm{E}-6 \\
<(0.0052)\end{array}$ & $\begin{array}{l}<4.1 \mathrm{E}-6 \\
<(0.008)\end{array}$ & $\begin{array}{l}<2.6 \mathrm{E}-5 \\
<(0.051)\end{array}$ & $\begin{array}{l}<3.8 \mathrm{E}-5 \\
<(0.072)\end{array}$ & $\begin{array}{l}<1.1 \mathrm{E}-4 \\
<(0.208)\end{array}$ \\
\hline Postburn matrix leach 1 & $\begin{array}{c}5.12 \mathrm{E}-5 \\
(0.098)\end{array}$ & $\begin{array}{l}1.83 \mathrm{E}-3 \\
(3.510)\end{array}$ & $\begin{array}{c}2.28 \mathrm{E}-5 \\
(0.044)\end{array}$ & $\begin{array}{c}1.09 \mathrm{E}-4 \\
(0.209)\end{array}$ & $\begin{array}{c}1.35 \mathrm{E}-4 \\
(0.259)\end{array}$ & $\begin{array}{c}4.93 \mathrm{E}-5 \\
(0.094)\end{array}$ & $\begin{array}{c}4.84 \mathrm{E}-5 \\
(0.093)\end{array}$ & $\begin{array}{c}5.83 \mathrm{E}-5 \\
(0.112)\end{array}$ & $\begin{array}{c}4.04 \mathrm{E}-4 \\
(0.774)\end{array}$ & $\begin{array}{c}4.83 \mathrm{E}-4 \\
(0.926)\end{array}$ \\
\hline Postburn matrix leach 2 & $\begin{array}{l}<4.3 \mathrm{E}-5 \\
<(0.083)\end{array}$ & $\begin{array}{c}2.89 \mathrm{E}-4 \\
(0.555)\end{array}$ & $\begin{array}{c}4.19 \mathrm{E}-6 \\
(0.008)\end{array}$ & $\begin{array}{l}4.64 \mathrm{E}-6 \\
(0.0089)\end{array}$ & $\begin{array}{c}1.11 \mathrm{E}-5 \\
(0.021)\end{array}$ & $\begin{array}{l}2.55 \mathrm{E}-6 \\
(0.0049)\end{array}$ & $\begin{array}{c}2.51 \mathrm{E}-6 \\
(0.0048)\end{array}$ & $\begin{array}{l}<1.5 \mathrm{E}-5 \\
<(0.029)\end{array}$ & $\begin{array}{l}<2.1 \mathrm{E}-5 \\
<(0.041)\end{array}$ & $\begin{array}{l}<6.2 \mathrm{E}-5 \\
<(0.119)\end{array}$ \\
\hline Postburn particle leach $1^{a}$ & $\begin{array}{l}<8.9 \mathrm{E}-5 \\
<(0.171)\end{array}$ & $\begin{array}{c}5.13 \mathrm{E}-4 \\
(0.984)\end{array}$ & $\begin{array}{c}4.97 \mathrm{E}-5 \\
(0.095)\end{array}$ & $\begin{array}{c}4.46 \mathrm{E}-5 \\
(0.086)\end{array}$ & $\begin{array}{c}1.61 \mathrm{E}-4 \\
(0.310)\end{array}$ & $\begin{array}{c}7.13 \mathrm{E}-5 \\
(0.137)\end{array}$ & $\begin{array}{c}7.39 \mathrm{E}-5 \\
(0.142)\end{array}$ & $\begin{array}{c}5.69 \mathrm{E}-5 \\
(0.109)\end{array}$ & $\begin{array}{c}2.29 \mathrm{E}-4 \\
(0.439)\end{array}$ & $\begin{array}{c}6.51 \mathrm{E}-4 \\
(1.249)\end{array}$ \\
\hline Postburn particle leach $2^{a}$ & $\begin{array}{l}<8.7 \mathrm{E}-5 \\
<(0.166)\end{array}$ & $\begin{array}{l}<1.1 \mathrm{E}-4 \\
<(0.207)\end{array}$ & $\begin{array}{l}1.13 \mathrm{E}-5 \\
(0.022)\end{array}$ & $\begin{array}{l}1.18 \mathrm{E}-5 \\
(0.023)\end{array}$ & $\begin{array}{c}7.39 \mathrm{E}-5 \\
(0.142)\end{array}$ & $\begin{array}{c}7.19 \mathrm{E}-6 \\
(0.014)\end{array}$ & $\begin{array}{c}1.96 \mathrm{E}-5 \\
(0.038)\end{array}$ & $\begin{array}{l}<3.0 \mathrm{E}-5 \\
<(0.058)\end{array}$ & $\begin{array}{l}<4.3 \mathrm{E}-5 \\
<(0.082)\end{array}$ & $\begin{array}{l}<1.2 \mathrm{E}-4 \\
<(0.237)\end{array}$ \\
\hline Total & $\begin{array}{c}5.12 \mathrm{E}-5 \\
(0.098)\end{array}$ & $\begin{array}{c}4.87 \mathrm{E}-3 \\
(9.344)\end{array}$ & $\begin{array}{c}1.33 \mathrm{E}-4 \\
(0.255)\end{array}$ & $\begin{array}{c}2.73 \mathrm{E}-4 \\
(0.523)\end{array}$ & $\begin{array}{c}6.04 \mathrm{E}-4 \\
(1.159)\end{array}$ & $\begin{array}{c}1.66 \mathrm{E}-4 \\
(0.318)\end{array}$ & $\begin{array}{c}1.81 \mathrm{E}-4 \\
(0.347)\end{array}$ & $\begin{array}{c}1.62 \mathrm{E}-4 \\
(0.311)\end{array}$ & $\begin{array}{c}9.47 \mathrm{E}-4 \\
(1.815)\end{array}$ & $\begin{array}{c}1.57 \mathrm{E}-3 \\
(3.002)\end{array}$ \\
\hline
\end{tabular}

Note: Values are reported as compact inventory fractions and particle equivalents (in parentheses).

Note: A less-than value indicates that the concentration in the leachate was below the minimum detectable limit; these values are not included in the totals.

${ }^{a}$ Postburn particle leach data were scaled to account for $\sim 8 \%$ particle population withheld from postburn analysis. 
Appendix Table A-20. Exposed inventory of stable nuclides of interest detected by DLBL of AGR-3/4 Compact 10-4 Segment 2

\begin{tabular}{|c|c|c|c|c|c|c|c|c|c|c|}
\hline DLBL Step & ${ }^{105} \mathbf{P d}$ & ${ }^{109} \mathrm{Ag}$ & ${ }^{133} \mathrm{Cs}$ & ${ }^{139} \mathbf{L a}$ & ${ }^{140} \mathrm{Ce}$ & ${ }^{141} \mathrm{Pr}$ & ${ }^{146} \mathrm{Nd}$ & ${ }^{152} \mathrm{Sm}$ & ${ }^{153} \mathbf{E u}$ & ${ }^{156} \mathrm{Gd}$ \\
\hline Deconsolidation acid & $\begin{array}{l}<5.2 \mathrm{E}-5 \\
<(0.100)\end{array}$ & $\begin{array}{c}1.13 \mathrm{E}-3 \\
(2.168)\end{array}$ & $\begin{array}{c}1.13 \mathrm{E}-4 \\
(0.216)\end{array}$ & $\begin{array}{c}9.59 \mathrm{E}-5 \\
(0.184)\end{array}$ & $\begin{array}{c}8.43 \mathrm{E}-5 \\
(0.162)\end{array}$ & $\begin{array}{c}9.20 \mathrm{E}-5 \\
(0.176)\end{array}$ & $\begin{array}{c}9.71 \mathrm{E}-5 \\
(0.186)\end{array}$ & $\begin{array}{c}9.58 \mathrm{E}-5 \\
(0.184)\end{array}$ & $\begin{array}{c}2.92 \mathrm{E}-4 \\
(0.561)\end{array}$ & $\begin{array}{c}3.99 \mathrm{E}-4 \\
(0.765)\end{array}$ \\
\hline Preburn leach 1 & $\begin{array}{l}<7.2 \mathrm{E}-5 \\
<(0.139)\end{array}$ & $\begin{array}{c}3.45 \mathrm{E}-4 \\
(0.662)\end{array}$ & $\begin{array}{l}1.84 \mathrm{E}-5 \\
(0.035)\end{array}$ & $\begin{array}{c}5.16 \mathrm{E}-5 \\
(0.099)\end{array}$ & $\begin{array}{c}8.18 \mathrm{E}-5 \\
(0.157)\end{array}$ & $\begin{array}{c}8.18 \mathrm{E}-6 \\
(0.016)\end{array}$ & $\begin{array}{c}8.00 \mathrm{E}-6 \\
(0.015)\end{array}$ & $\begin{array}{l}<2.5 \mathrm{E}-5 \\
<(0.048)\end{array}$ & $\begin{array}{l}1.32 \mathrm{E}-4 \\
(0.254)\end{array}$ & $\begin{array}{c}1.77 \mathrm{E}-4 \\
(0.340)\end{array}$ \\
\hline Preburn leach 2 & $\begin{array}{l}<7.7 \mathrm{E}-5 \\
<(0.148)\end{array}$ & $\begin{array}{c}9.07 \mathrm{E}-4 \\
(1.740)\end{array}$ & $\begin{array}{c}6.28 \mathrm{E}-6 \\
(0.012)\end{array}$ & $\begin{array}{c}9.11 \mathrm{E}-6 \\
(0.017)\end{array}$ & $\begin{array}{c}4.60 \mathrm{E}-5 \\
(0.088)\end{array}$ & $\begin{array}{l}3.45 \mathrm{E}-6 \\
(0.0066)\end{array}$ & $\begin{array}{l}<4.2 \mathrm{E}-6 \\
<(0.0081)\end{array}$ & $\begin{array}{l}<2.7 \mathrm{E}-5 \\
<(0.052)\end{array}$ & $\begin{array}{c}3.98 \mathrm{E}-5 \\
(0.076)\end{array}$ & $\begin{array}{l}<1.1 \mathrm{E}-4 \\
<(0.212)\end{array}$ \\
\hline Postburn matrix leach 1 & $\begin{array}{c}4.87 \mathrm{E}-5 \\
(0.093)\end{array}$ & $\begin{array}{l}1.44 \mathrm{E}-3 \\
(2.755)\end{array}$ & $\begin{array}{l}1.70 \mathrm{E}-5 \\
(0.033)\end{array}$ & $\begin{array}{c}8.93 \mathrm{E}-5 \\
(0.171)\end{array}$ & $\begin{array}{l}1.35 \mathrm{E}-4 \\
(0.258)\end{array}$ & $\begin{array}{c}3.39 \mathrm{E}-5 \\
(0.065)\end{array}$ & $\begin{array}{c}3.25 \mathrm{E}-5 \\
(0.062)\end{array}$ & $\begin{array}{c}4.81 \mathrm{E}-5 \\
(0.092)\end{array}$ & $\begin{array}{c}4.77 \mathrm{E}-4 \\
(0.915)\end{array}$ & $\begin{array}{c}4.77 \mathrm{E}-4 \\
(0.915)\end{array}$ \\
\hline Postburn matrix leach 2 & $\begin{array}{l}<4.8 \mathrm{E}-5 \\
<(0.093)\end{array}$ & $\begin{array}{c}9.04 \mathrm{E}-5 \\
(0.173)\end{array}$ & $\begin{array}{l}4.46 \mathrm{E}-6 \\
(0.0086)\end{array}$ & $\begin{array}{c}6.36 \mathrm{E}-6 \\
(0.012)\end{array}$ & $\begin{array}{l}1.69 \mathrm{E}-5 \\
(0.032)\end{array}$ & $\begin{array}{c}8.46 \mathrm{E}-6 \\
(0.016)\end{array}$ & $\begin{array}{c}7.24 \mathrm{E}-6 \\
(0.014)\end{array}$ & $\begin{array}{l}<1.7 \mathrm{E}-5 \\
<(0.032)\end{array}$ & $\begin{array}{l}<2.4 \mathrm{E}-5 \\
<(0.046)\end{array}$ & $\begin{array}{l}<6.9 \mathrm{E}-5 \\
<(0.132)\end{array}$ \\
\hline Postburn particle leach $1^{a}$ & $\begin{array}{l}<9.4 \mathrm{E}-5 \\
<(0.181)\end{array}$ & $\begin{array}{c}4.71 \mathrm{E}-4 \\
(0.904)\end{array}$ & $\begin{array}{c}3.48 \mathrm{E}-5 \\
(0.067)\end{array}$ & $\begin{array}{c}4.15 \mathrm{E}-5 \\
(0.080)\end{array}$ & $\begin{array}{l}1.63 \mathrm{E}-4 \\
(0.312)\end{array}$ & $\begin{array}{c}6.78 \mathrm{E}-5 \\
(0.130)\end{array}$ & $\begin{array}{c}6.88 \mathrm{E}-5 \\
(0.132)\end{array}$ & $\begin{array}{c}4.92 \mathrm{E}-5 \\
(0.094)\end{array}$ & $\begin{array}{l}7.80 \mathrm{E}-4 \\
(1.496)\end{array}$ & $\begin{array}{l}7.18 \mathrm{E}-4 \\
(1.377)\end{array}$ \\
\hline Postburn particle leach $2^{a}$ & $\begin{array}{l}<8.6 \mathrm{E}-5 \\
<(0.165)\end{array}$ & $\begin{array}{c}2.40 \mathrm{E}-4 \\
(0.461)\end{array}$ & $\begin{array}{l}1.64 \mathrm{E}-5 \\
(0.031)\end{array}$ & $\begin{array}{c}6.40 \mathrm{E}-6 \\
(0.012)\end{array}$ & $\begin{array}{c}9.29 \mathrm{E}-5 \\
(0.178)\end{array}$ & $\begin{array}{l}1.03 \mathrm{E}-5 \\
(0.020)\end{array}$ & $\begin{array}{c}1.06 \mathrm{E}-5 \\
(0.020)\end{array}$ & $\begin{array}{l}<3.0 \mathrm{E}-5 \\
<(0.057)\end{array}$ & $\begin{array}{c}5.83 \mathrm{E}-5 \\
(0.112)\end{array}$ & $\begin{array}{c}1.33 \mathrm{E}-4 \\
(0.254)\end{array}$ \\
\hline Total & $\begin{array}{c}4.87 \mathrm{E}-5 \\
(0.093)\end{array}$ & $\begin{array}{c}4.62 \mathrm{E}-3 \\
(8.863)\end{array}$ & $\begin{array}{c}2.10 \mathrm{E}-4 \\
(0.403)\end{array}$ & $\begin{array}{c}3.00 \mathrm{E}-4 \\
(0.576)\end{array}$ & $\begin{array}{c}6.19 \mathrm{E}-4 \\
(1.187)\end{array}$ & $\begin{array}{c}2.24 \mathrm{E}-4 \\
(0.430)\end{array}$ & $\begin{array}{c}2.24 \mathrm{E}-4 \\
(0.430)\end{array}$ & $\begin{array}{l}1.93 \mathrm{E}-4 \\
(0.370)\end{array}$ & $\begin{array}{l}1.78 \mathrm{E}-3 \\
(3.414)\end{array}$ & $\begin{array}{l}1.90 \mathrm{E}-3 \\
(3.653)\end{array}$ \\
\hline
\end{tabular}

Note: Values are reported as compact inventory fractions and particle equivalents (in parentheses).

Note: A less-than value indicates that the concentration in the leachate was below the minimum detectable limit; these values are not included in the totals.

${ }^{a}$ Postburn particle leach data were scaled to account for $\sim 10 \%$ particle population withheld from postburn analysis. 
Appendix Table A-21. Exposed inventory of stable nuclides of interest detected by DLBL of AGR-3/4 Compact 10-4 Segment 3

\begin{tabular}{|c|c|c|c|c|c|c|c|c|c|c|}
\hline DLBL Step & ${ }^{105} \mathrm{Pd}$ & ${ }^{109} \mathrm{Ag}$ & ${ }^{133} \mathrm{Cs}$ & ${ }^{139} \mathrm{La}$ & ${ }^{140} \mathrm{Ce}$ & ${ }^{141} \mathrm{Pr}$ & ${ }^{146} \mathrm{Nd}$ & ${ }^{152} \mathrm{Sm}$ & ${ }^{153} \mathbf{E u}$ & ${ }^{156} \mathbf{G d}$ \\
\hline Deconsolidation acid & $\begin{array}{c}7.76 \mathrm{E}-5 \\
(0.149)\end{array}$ & $\begin{array}{c}3.63 \mathrm{E}-3 \\
(6.958)\end{array}$ & $\begin{array}{l}1.42 \mathrm{E}-3 \\
(2.718)\end{array}$ & $\begin{array}{c}3.66 \mathrm{E}-3 \\
(7.029)\end{array}$ & $\begin{array}{c}4.09 \mathrm{E}-3 \\
(7.838)\end{array}$ & $\begin{array}{c}4.48 \mathrm{E}-3 \\
(8.601)\end{array}$ & $\begin{array}{c}4.46 \mathrm{E}-3 \\
(8.545)\end{array}$ & $\begin{array}{l}3.82 \mathrm{E}-3 \\
(7.323)\end{array}$ & $\begin{array}{l}1.71 \mathrm{E}-3 \\
(3.282)\end{array}$ & $\begin{array}{c}6.44 \mathrm{E}-3 \\
(12.357)\end{array}$ \\
\hline Preburn leach 1 & $\begin{array}{l}<8.0 \mathrm{E}-5 \\
<(0.153)\end{array}$ & $\begin{array}{l}1.71 \mathrm{E}-3 \\
(3.274)\end{array}$ & $\begin{array}{c}1.91 \mathrm{E}-4 \\
(0.366)\end{array}$ & $\begin{array}{l}1.14 \mathrm{E}-3 \\
(2.182)\end{array}$ & $\begin{array}{l}1.12 \mathrm{E}-3 \\
(2.147)\end{array}$ & $\begin{array}{c}9.76 \mathrm{E}-4 \\
(1.871)\end{array}$ & $\begin{array}{c}7.53 \mathrm{E}-4 \\
(1.443)\end{array}$ & $\begin{array}{c}7.57 \mathrm{E}-4 \\
(1.451)\end{array}$ & $\begin{array}{c}6.83 \mathrm{E}-4 \\
(1.309)\end{array}$ & $\begin{array}{l}1.66 \mathrm{E}-3 \\
(3.183)\end{array}$ \\
\hline Preburn leach 2 & $\begin{array}{l}<8.2 \mathrm{E}-5 \\
<(0.158)\end{array}$ & $\begin{array}{c}2.93 \mathrm{E}-4 \\
(0.562)\end{array}$ & $\begin{array}{c}1.85 \mathrm{E}-5 \\
(0.035)\end{array}$ & $\begin{array}{l}1.38 \mathrm{E}-4 \\
(0.265)\end{array}$ & $\begin{array}{c}1.79 \mathrm{E}-4 \\
(0.343)\end{array}$ & $\begin{array}{c}1.40 \mathrm{E}-4 \\
(0.268)\end{array}$ & $\begin{array}{l}1.15 \mathrm{E}-4 \\
(0.220)\end{array}$ & $\begin{array}{c}8.31 \mathrm{E}-5 \\
(0.159)\end{array}$ & $\begin{array}{c}7.17 \mathrm{E}-5 \\
(0.138)\end{array}$ & $\begin{array}{c}2.29 \mathrm{E}-4 \\
(0.440)\end{array}$ \\
\hline Postburn matrix leach 1 & $\begin{array}{c}1.92 \mathrm{E}-4 \\
(0.369)\end{array}$ & $\begin{array}{c}2.13 \mathrm{E}-3 \\
(4.089)\end{array}$ & $\begin{array}{c}2.08 \mathrm{E}-4 \\
(0.399)\end{array}$ & $\begin{array}{l}1.42 \mathrm{E}-3 \\
(2.732)\end{array}$ & $\begin{array}{l}1.46 \mathrm{E}-3 \\
(2.795)\end{array}$ & $\begin{array}{l}1.33 \mathrm{E}-3 \\
(2.543)\end{array}$ & $\begin{array}{l}1.09 \mathrm{E}-3 \\
(2.096)\end{array}$ & $\begin{array}{l}1.38 \mathrm{E}-3 \\
(2.650)\end{array}$ & $\begin{array}{l}1.96 \mathrm{E}-3 \\
(3.761)\end{array}$ & $\begin{array}{c}3.66 \mathrm{E}-3 \\
(7.018)\end{array}$ \\
\hline Postburn matrix leach 2 & $\begin{array}{l}<4.5 \mathrm{E}-5 \\
<(0.087)\end{array}$ & $\begin{array}{c}2.51 \mathrm{E}-4 \\
(0.481)\end{array}$ & $\begin{array}{c}1.06 \mathrm{E}-5 \\
(0.020)\end{array}$ & $\begin{array}{c}3.20 \mathrm{E}-5 \\
(0.061)\end{array}$ & $\begin{array}{c}4.31 \mathrm{E}-5 \\
(0.083)\end{array}$ & $\begin{array}{c}3.04 \mathrm{E}-5 \\
(0.058)\end{array}$ & $\begin{array}{c}2.58 \mathrm{E}-5 \\
(0.049)\end{array}$ & $\begin{array}{c}2.82 \mathrm{E}-5 \\
(0.054)\end{array}$ & $\begin{array}{c}5.16 \mathrm{E}-5 \\
(0.099)\end{array}$ & $\begin{array}{c}1.17 \mathrm{E}-4 \\
(0.225)\end{array}$ \\
\hline Postburn particle leach $1^{a}$ & $\begin{array}{c}1.74 \mathrm{E}-4 \\
(0.334)\end{array}$ & $\begin{array}{c}5.48 \mathrm{E}-4 \\
(1.052)\end{array}$ & $\begin{array}{c}3.97 \mathrm{E}-5 \\
(0.076)\end{array}$ & $\begin{array}{l}1.11 \mathrm{E}-3 \\
(2.137)\end{array}$ & $\begin{array}{c}2.92 \mathrm{E}-3 \\
(5.604)\end{array}$ & $\begin{array}{c}2.59 \mathrm{E}-3 \\
(4.970)\end{array}$ & $\begin{array}{c}1.85 \mathrm{E}-3 \\
(3.539)\end{array}$ & $\begin{array}{c}2.72 \mathrm{E}-3 \\
(5.224)\end{array}$ & $\begin{array}{c}2.27 \mathrm{E}-3 \\
(4.353)\end{array}$ & $\begin{array}{c}4.11 \mathrm{E}-3 \\
(7.881)\end{array}$ \\
\hline Postburn particle leach $2^{a}$ & $\begin{array}{l}<8.3 \mathrm{E}-5 \\
<(0.160)\end{array}$ & $\begin{array}{c}2.01 \mathrm{E}-3 \\
(3.860)\end{array}$ & $\begin{array}{c}7.33 \mathrm{E}-5 \\
(0.141)\end{array}$ & $\begin{array}{c}5.54 \mathrm{E}-5 \\
(0.106)\end{array}$ & $\begin{array}{c}1.61 \mathrm{E}-4 \\
(0.309)\end{array}$ & $\begin{array}{c}8.67 \mathrm{E}-5 \\
(0.166)\end{array}$ & $\begin{array}{c}9.17 \mathrm{E}-5 \\
(0.176)\end{array}$ & $\begin{array}{c}6.22 \mathrm{E}-5 \\
(0.119)\end{array}$ & $\begin{array}{c}2.77 \mathrm{E}-4 \\
(0.531)\end{array}$ & $\begin{array}{c}6.86 \mathrm{E}-4 \\
(1.316)\end{array}$ \\
\hline Total & $\begin{array}{c}4.44 \mathrm{E}-4 \\
(0.852)\end{array}$ & $\begin{array}{c}1.06 \mathrm{E}-2 \\
(20.275)\end{array}$ & $\begin{array}{c}1.96 \mathrm{E}-3 \\
(3.756)\end{array}$ & $\begin{array}{c}7.57 \mathrm{E}-3 \\
(14.514)\end{array}$ & $\begin{array}{c}9.97 \mathrm{E}-3 \\
(19.117)\end{array}$ & $\begin{array}{l}9.63 \mathrm{E}-3 \\
(18.479)\end{array}$ & $\begin{array}{c}8.38 \mathrm{E}-3 \\
(16.069)\end{array}$ & $\begin{array}{c}8.85 \mathrm{E}-3 \\
(16.982)\end{array}$ & $\begin{array}{c}7.02 \mathrm{E}-3 \\
(13.473)\end{array}$ & $\begin{array}{c}1.69 \mathrm{E}-2 \\
(32.421)\end{array}$ \\
\hline
\end{tabular}

Note: Values are reported as compact inventory fractions and particle equivalents (in parentheses).

Note: A less-than value indicates that the concentration in the leachate was below the minimum detectable limit; these values are not included in the totals.

${ }^{a}$ Postburn particle leach data were scaled to account for $\sim 7 \%$ particle population withheld from postburn analysis. 
Appendix Table A-22. Concentration in each segment from AGR-3/4 Compact 1-4

\begin{tabular}{|c|c|c|c|c|}
\hline Nuclide & Segment $1^{a}$ & Segment 2 & Segment 3 & Segment 4 \\
\hline${ }^{235} \mathbf{U}$ & $3.41 \mathrm{E}-5 \quad(0.065)$ & $1.01 \mathrm{E}-3 \quad(1.931)$ & $1.59 \mathrm{E}-3 \quad(3.048)$ & $2.24 \mathrm{E}-2 \quad(43.044)$ \\
\hline${ }^{236} \mathbf{U}$ & $8.43 \mathrm{E}-5 \quad(0.162)$ & $1.31 \mathrm{E}-3 \quad(2.512)$ & $1.80 \mathrm{E}-3 \quad(3.459)$ & $2.29 \mathrm{E}-2 \quad(43.827)$ \\
\hline${ }^{238} \mathbf{U}$ & $2.29 \mathrm{E}-4 \quad(0.439)$ & $1.97 \mathrm{E}-3 \quad(3.783)$ & 2.19E-3 (4.209) & $2.25 \mathrm{E}-2 \quad(43.160)$ \\
\hline${ }^{239} \mathrm{Pu}$ & $3.48 \mathrm{E}-5 \quad(0.067)$ & $3.88 \mathrm{E}-4 \quad(0.744)$ & $6.16 \mathrm{E}-4 \quad(1.182)$ & $2.22 \mathrm{E}-2 \quad(42.577)$ \\
\hline${ }^{240} \mathrm{Pu}$ & $1.01 \mathrm{E}-4 \quad(0.193)$ & $1.05 \mathrm{E}-3 \quad(2.018)$ & 9.33E-4 (1.790) & $2.12 \mathrm{E}-2 \quad(40.594)$ \\
\hline${ }^{90} \mathrm{Sr}$ & $\begin{array}{ll}7.73 \mathrm{E}-5 \quad(0.148) \\
\end{array}$ & $1.09 \mathrm{E}-3 \quad(2.084)$ & $1.38 \mathrm{E}-3 \quad(2.644)$ & $2.78 \mathrm{E}-2 \quad(53.321)$ \\
\hline${ }^{106} \mathrm{Ru}$ & $2.86 \mathrm{E}-5 \quad(0.055)$ & $3.18 \mathrm{E}-4 \quad(0.610)$ & $5.13 \mathrm{E}-4 \quad(0.984)$ & $1.76 \mathrm{E}-2 \quad(33.753)$ \\
\hline${ }^{110 m} \mathrm{Ag}$ & $0.00 \mathrm{E}+0 \quad(0.000)$ & $0.00 \mathrm{E}+0 \quad(0.000)$ & $0.00 \mathrm{E}+0 \quad(0.000)$ & $0.00 \mathrm{E}+0 \quad(0.000)$ \\
\hline${ }^{125} \mathrm{Sb}$ & $1.66 \mathrm{E}-5 \quad(0.032)$ & $5.21 \mathrm{E}-5 \quad(0.100)$ & $0.00 \mathrm{E}+0 \quad(0.000)$ & $9.91 \mathrm{E}-3 \quad(19.017)$ \\
\hline${ }^{134} \mathrm{Cs}$ & $1.45 \mathrm{E}-4 \quad(0.278)$ & $1.64 \mathrm{E}-3 \quad(3.150)$ & $2.03 \mathrm{E}-3 \quad(3.887)$ & $1.42 \mathrm{E}-2 \quad(27.324)$ \\
\hline${ }^{137} \mathrm{Cs}$ & $2.05 \mathrm{E}-4 \quad(0.393)$ & $2.39 \mathrm{E}-3 \quad(4.578)$ & $2.85 \mathrm{E}-3 \quad(5.459)$ & $1.91 \mathrm{E}-2 \quad(36.591)$ \\
\hline${ }^{144} \mathrm{Ce}$ & $4.22 \mathrm{E}-5 \quad(0.081)$ & 9.96E-4 (1.911) & $1.16 \mathrm{E}-3 \quad(2.226)$ & $2.27 \mathrm{E}-2 \quad(43.498)$ \\
\hline${ }^{154} \mathbf{E u}$ & 2.03E-4 (0.389) & $1.72 \mathrm{E}-3 \quad(3.292)$ & $1.48 \mathrm{E}-3 \quad(2.844)$ & $1.82 \mathrm{E}-2 \quad(34.991)$ \\
\hline${ }^{155} \mathbf{E u}$ & $1.02 \mathrm{E}-4 \quad(0.196)$ & $1.61 \mathrm{E}-3 \quad(3.084)$ & $1.28 \mathrm{E}-3 \quad(2.449)$ & $1.86 \mathrm{E}-2 \quad(35.634)$ \\
\hline${ }^{105} \mathrm{Pd}$ & 9.60E-4 (1.840) & 1.02E-3 (1.954) & 5.53E-4 (1.060) & $1.04 \mathrm{E}-2 \quad(20.002)$ \\
\hline${ }^{109} \mathrm{Ag}$ & 7.04E-3 (13.508) & 4.56E-2 (87.447) & $3.52 \mathrm{E}-2 \quad(67.435)$ & $5.12 \mathrm{E}-2 \quad(98.243)$ \\
\hline${ }^{133} \mathrm{Cs}$ & $1.99 \mathrm{E}-4 \quad(0.381)$ & $2.33 \mathrm{E}-3 \quad(4.478)$ & $2.78 \mathrm{E}-3 \quad(5.339)$ & $1.79 \mathrm{E}-2 \quad(34.337)$ \\
\hline${ }^{139} \mathbf{L a}$ & 5.72E-4 (1.097) & $2.99 \mathrm{E}-3 \quad(5.730)$ & $2.46 \mathrm{E}-3 \quad(4.716)$ & $2.27 \mathrm{E}-2 \quad(43.599)$ \\
\hline${ }^{140} \mathrm{Ce}$ & $6.18 \mathrm{E}-4 \quad(1.185)$ & 4.60E-3 (8.831) & $3.41 \mathrm{E}-3 \quad(6.543)$ & $2.50 \mathrm{E}-2 \quad(48.004)$ \\
\hline${ }^{141} \mathrm{Pr}$ & $1.39 \mathrm{E}-4 \quad(0.267)$ & $1.86 \mathrm{E}-3 \quad(3.562)$ & $1.75 \mathrm{E}-3 \quad(3.359)$ & $2.27 \mathrm{E}-2 \quad(43.633)$ \\
\hline${ }^{146} \mathrm{Nd}$ & $1.36 \mathrm{E}-4 \quad(0.261)$ & $1.72 \mathrm{E}-3 \quad(3.291)$ & $1.61 \mathrm{E}-3 \quad(3.089)$ & $1.93 \mathrm{E}-2 \quad(37.047)$ \\
\hline${ }^{152} \mathrm{Sm}$ & $9.47 \mathrm{E}-5 \quad(0.182)$ & $1.72 \mathrm{E}-3 \quad(3.307)$ & $3.98 \mathrm{E}-3 \quad(7.638)$ & $2.11 \mathrm{E}-2 \quad(40.389)$ \\
\hline${ }^{153} \mathbf{E u}$ & $3.16 \mathrm{E}-4 \quad(0.607)$ & $3.36 \mathrm{E}-3 \quad(6.454)$ & $8.53 \mathrm{E}-3 \quad(16.358)$ & $2.05 \mathrm{E}-2 \quad(39.257)$ \\
\hline${ }^{156} \mathrm{Gd}$ & $1.50 \mathrm{E}-3 \quad(2.872)$ & $1.39 \mathrm{E}-2 \quad(26.619)$ & $9.81 \mathrm{E}-3 \quad(18.814)$ & 5.17E-2 (99.179) \\
\hline
\end{tabular}


Appendix Table A-23. Concentration in each segment from AGR-3/4 Compact 10-4

\begin{tabular}{|c|c|c|c|}
\hline Nuclide & Segment 1 & Segment 2 & Segment 3 \\
\hline${ }^{235} \mathbf{U}$ & $2.27 \mathrm{E}-4 \quad(0.436)$ & $1.14 \mathrm{E}-3 \quad(2.178)$ & $2.08 \mathrm{E}-2 \quad(39.935)$ \\
\hline${ }^{236} \mathbf{U}$ & $2.79 \mathrm{E}-4 \quad(0.536)$ & $1.17 \mathrm{E}-3 \quad(2.247)$ & $1.98 \mathrm{E}-2 \quad(37.928)$ \\
\hline${ }^{238} \mathbf{U}$ & 5.96E-4 (1.144) & $1.60 \mathrm{E}-3 \quad(3.066)$ & $2.12 \mathrm{E}-2 \quad(40.637)$ \\
\hline${ }^{239} \mathrm{Pu}$ & $2.89 \mathrm{E}-4 \quad(0.554)$ & $8.08 \mathrm{E}-4 \quad(1.550)$ & $1.74 \mathrm{E}-2 \quad(33.456)$ \\
\hline${ }^{240} \mathrm{Pu}$ & $4.32 \mathrm{E}-4 \quad(0.829)$ & 9.93E-4 (1.905) & $1.83 \mathrm{E}-2 \quad(35.109)$ \\
\hline${ }^{90} \mathrm{Sr}$ & $1.91 \mathrm{E}-3 \quad(3.668)$ & $3.15 \mathrm{E}-3 \quad(6.035)$ & $1.04 \mathrm{E}-2 \quad(19.920)$ \\
\hline${ }^{106} \mathrm{Ru}$ & $3.69 \mathrm{E}-5 \quad(0.071)$ & $3.16 \mathrm{E}-4 \quad(0.606)$ & $1.53 \mathrm{E}-2 \quad(29.374)$ \\
\hline${ }^{110 m} \mathrm{Ag}$ & $0.00 \mathrm{E}+0 \quad(0.000)$ & $0.00 \mathrm{E}+0 \quad(0.000)$ & $0.00 \mathrm{E}+0 \quad(0.000)$ \\
\hline${ }^{125} \mathrm{Sb}$ & $1.32 \mathrm{E}-4 \quad(0.252)$ & $6.74 \mathrm{E}-5 \quad(0.129)$ & $1.38 \mathrm{E}-3 \quad(2.651)$ \\
\hline${ }^{134} \mathrm{Cs}$ & $2.39 \mathrm{E}-5 \quad(0.046)$ & $8.40 \mathrm{E}-5 \quad(0.161)$ & 9.16E-4 (1.756) \\
\hline${ }^{137} \mathrm{Cs}$ & $1.97 \mathrm{E}-4 \quad(0.378)$ & 4.44E-4 (0.852) & $3.99 \mathrm{E}-3 \quad(7.646)$ \\
\hline${ }^{144} \mathrm{Ce}$ & $5.51 \mathrm{E}-5 \quad(0.106)$ & $2.21 \mathrm{E}-4 \quad(0.424)$ & $1.90 \mathrm{E}-2 \quad(36.441)$ \\
\hline${ }^{154} \mathbf{E u}$ & $1.79 \mathrm{E}-3 \quad(3.439)$ & $2.94 \mathrm{E}-3 \quad(5.639)$ & $1.03 \mathrm{E}-2 \quad(19.757)$ \\
\hline${ }^{155} \mathbf{E u}$ & $1.82 \mathrm{E}-3 \quad(3.489)$ & $2.90 \mathrm{E}-3 \quad(5.553)$ & $1.14 \mathrm{E}-2 \quad(21.848)$ \\
\hline${ }^{105} \mathrm{Pd}$ & $9.52 \mathrm{E}-5 \quad(0.183)$ & $1.20 \mathrm{E}-4 \quad(0.230)$ & $8.92 \mathrm{E}-4 \quad(1.711)$ \\
\hline${ }^{109} \mathrm{Ag}$ & $9.06 \mathrm{E}-3 \quad(17.371)$ & $1.14 \mathrm{E}-2 \quad(21.811)$ & $2.12 \mathrm{E}-2 \quad(40.732)$ \\
\hline${ }^{133} \mathrm{Cs}$ & $2.47 \mathrm{E}-4 \quad(0.474)$ & $5.17 \mathrm{E}-4 \quad(0.992)$ & $3.93 \mathrm{E}-3 \quad(7.546)$ \\
\hline${ }^{139} \mathrm{La}$ & $5.07 \mathrm{E}-4 \quad(0.973)$ & 7.39E-4 (1.417) & $1.52 \mathrm{E}-2 \quad(29.159)$ \\
\hline${ }^{140} \mathrm{Ce}$ & $1.12 \mathrm{E}-3 \quad(2.155)$ & $1.52 \mathrm{E}-3 \quad(2.922)$ & $2.00 \mathrm{E}-2 \quad(38.407)$ \\
\hline${ }^{141} \mathrm{Pr}$ & $3.08 \mathrm{E}-4 \quad(0.591)$ & $5.51 \mathrm{E}-4 \quad(1.058)$ & $1.94 \mathrm{E}-2 \quad(37.124)$ \\
\hline${ }^{146} \mathrm{Nd}$ & $3.36 \mathrm{E}-4 \quad(0.645)$ & $5.52 \mathrm{E}-4 \quad(1.058)$ & $1.68 \mathrm{E}-2 \quad(32.282)$ \\
\hline${ }^{152} \mathrm{Sm}$ & $3.02 \mathrm{E}-4 \quad(0.578)$ & 4.75E-4 (0.912) & $1.78 \mathrm{E}-2 \quad(34.117)$ \\
\hline${ }^{153} \mathbf{E u}$ & $1.76 \mathrm{E}-3 \quad(3.375)$ & $4.38 \mathrm{E}-3 \quad(8.401)$ & $1.41 \mathrm{E}-2 \quad(27.067)$ \\
\hline${ }^{156} \mathbf{G d}$ & $2.91 \mathrm{E}-3 \quad(5.580)$ & $4.69 \mathrm{E}-3 \quad(8.989)$ & $3.40 \mathrm{E}-2 \quad(65.134)$ \\
\hline
\end{tabular}




\section{APPENDIX B. IMGA DATA}

The tables in this appendix document the IMGA data for key gamma-emitting fission products. Values are reported as measured activities in units of $\mathrm{Bq}$ that have been decay-corrected to one day after EOL and as various unitless ratios, as described in Section 2. The M/A values (e.g., Equation 2.1) are indicative of particle-to-particle variation in isotopic content. For particles with negligible radionuclide release, this particle-to-particle variation may be related to variation in fissionable material and/or burnup. Fissionable material in an as-fabricated particle may vary due to variation in kernel size (e.g., spherical kernels with different diameters or fragmented kernels), variation in kernel uranium fraction, and/or variation in uranium enrichment. Variation in local neutron fluence will cause a variation in burnup between spatially-separated particles even if the physical properties of the particles are identical. The M/AA values (e.g., Equation 2.4) are adjusted using a normally well retained nuclide to attempt to separate the variation in M/A as a function of fission product retention from the variation as a function of fissionable material and/or burnup $\left({ }^{144} \mathrm{Ce}\right.$ was used for the M/AA values reported herein). This makes the $\mathrm{M} / \mathrm{AA}$ values indicative of the fission product retention in a particle relative to the average of all measured RS particles. Particles with M/AA near unity for a given nuclide exhibited close to average retention of that nuclide. However, if a given nuclide was released from a large fraction of particles, then an M/AA value of unity does not indicate good retention of that nuclide. Such was often the case for ${ }^{110 \mathrm{~m}} \mathrm{Ag}$ in particles from the AGR-1 and AGR-2 experiments (Demkowicz et al. 2016, Hunn et al. 2018). The M/C values (e.g., Equation 2.3) provide an indication of the particle inventory relative to the average calculated inventory (Appendix C). For well retained nuclides, the mean $\mathrm{M} / \mathrm{C}$ values are typically $1.00 \pm 0.10$, where the variation is mostly due to error in the calculated average inventories stemming from uncertainty in the values used for the calculation. For the AGR-1 and AGR-2 irradiations, the mean M/C

values for ${ }^{125} \mathrm{Sb}$ and ${ }^{154} \mathrm{Eu}$ have been consistently offset from unity by more than $10 \%$ due to larger errors in the calculated values. 
Appendix Table B-1. Radionuclide inventories of particles from AGR-3/4 Compact 1-4

\begin{tabular}{|c|c|c|c|c|c|c|c|}
\hline Particle & Value & ${ }^{106} \mathrm{Ru}$ & ${ }^{125} \mathrm{Sb}$ & ${ }^{134} \mathrm{Cs}$ & ${ }^{137} \mathrm{Cs}$ & ${ }^{144} \mathrm{Ce}$ & ${ }^{154} \mathbf{E u}$ \\
\hline 014-S4-SP01 & $\mathrm{Bq}$ & $4.24 \mathrm{E}+6$ & $9.18 \mathrm{E}+4$ & $9.70 \mathrm{E}+5$ & $1.89 \mathrm{E}+6$ & $2.75 \mathrm{E}+7$ & $3.04 \mathrm{E}+4$ \\
\hline 014-S4-SP01 & $\mathrm{M} / \mathrm{A}$ & 1.06 & 0.97 & 1.04 & 1.01 & 0.99 & 1.06 \\
\hline 014-S4-SP01 & $\mathrm{M} / \mathrm{AA}$ & 1.05 & 0.96 & 1.03 & 1.00 & 0.98 & 1.05 \\
\hline 014-S4-SP01 & $\mathrm{M} / \mathrm{C}$ & 1.04 & 0.72 & 1.03 & 1.05 & 0.94 & 0.94 \\
\hline 014-S1-RS01 & $\mathrm{Bq}$ & $4.53 \mathrm{E}+6$ & $9.96 \mathrm{E}+4$ & $1.02 \mathrm{E}+6$ & $1.95 \mathrm{E}+6$ & $2.90 \mathrm{E}+7$ & $3.19 \mathrm{E}+4$ \\
\hline 014-S1-RS01 & $\mathrm{M} / \mathrm{A}$ & 1.13 & 1.06 & 1.09 & 1.04 & 1.04 & 1.12 \\
\hline 014-S1-RS01 & M/AA & 1.08 & 1.01 & 1.04 & 1.00 & 1.00 & 1.07 \\
\hline 014-S1-RS01 & $\mathrm{M} / \mathrm{C}$ & 1.08 & 0.76 & 1.05 & 1.05 & 0.96 & 0.96 \\
\hline 014-S1-RS02 & $\mathrm{Bq}$ & $3.42 \mathrm{E}+6$ & $8.49 \mathrm{E}+4$ & $8.00 \mathrm{E}+5$ & $1.64 \mathrm{E}+6$ & $2.47 \mathrm{E}+7$ & $2.38 \mathrm{E}+4$ \\
\hline 014-S1-RS02 & $\mathrm{M} / \mathrm{A}$ & 0.85 & 0.90 & 0.86 & 0.87 & 0.89 & 0.83 \\
\hline 014-S1-RS02 & $\mathrm{M} / \mathrm{AA}$ & 0.98 & 1.03 & 0.98 & 1.00 & 1.02 & 0.95 \\
\hline 014-S1-RS02 & $\mathrm{M} / \mathrm{C}$ & 0.97 & 0.77 & 0.98 & 1.05 & 0.98 & 0.85 \\
\hline 014-S1-RS03 & $\mathrm{Bq}$ & $3.80 \mathrm{E}+6$ & $9.39 \mathrm{E}+4$ & $8.88 \mathrm{E}+5$ & $1.73 \mathrm{E}+6$ & $2.56 \mathrm{E}+7$ & $2.69 \mathrm{E}+4$ \\
\hline 014-S1-RS03 & $\mathrm{M} / \mathrm{A}$ & 0.95 & 1.00 & 0.95 & 0.92 & 0.92 & 0.94 \\
\hline 014-S1-RS03 & $\mathrm{M} / \mathrm{AA}$ & 1.02 & 1.08 & 1.03 & 1.00 & 1.00 & 1.02 \\
\hline 014-S1-RS03 & $\mathrm{M} / \mathrm{C}$ & 1.02 & 0.81 & 1.03 & 1.05 & 0.96 & 0.91 \\
\hline 014-S1-RS04 & $\mathrm{Bq}$ & $4.35 \mathrm{E}+6$ & $9.92 \mathrm{E}+4$ & $9.88 \mathrm{E}+5$ & $1.99 \mathrm{E}+6$ & $2.95 \mathrm{E}+7$ & $2.97 \mathrm{E}+4$ \\
\hline 014-S1-RS04 & $\mathrm{M} / \mathrm{A}$ & 1.09 & 1.05 & 1.06 & 1.06 & 1.06 & 1.04 \\
\hline 014-S1-RS04 & $\mathrm{M} / \mathrm{AA}$ & 1.02 & 0.99 & 0.99 & 1.00 & 1.00 & 0.98 \\
\hline 014-S1-RS04 & $\mathrm{M} / \mathrm{C}$ & 1.02 & 0.74 & 1.00 & 1.05 & 0.96 & 0.87 \\
\hline 014-S1-RS05 & $\mathrm{Bq}$ & $3.92 \mathrm{E}+6$ & $9.12 \mathrm{E}+4$ & $8.95 \mathrm{E}+5$ & $1.85 \mathrm{E}+6$ & $2.73 \mathrm{E}+7$ & $2.74 \mathrm{E}+4$ \\
\hline 014-S1-RS05 & $\mathrm{M} / \mathrm{A}$ & 0.98 & 0.97 & 0.96 & 0.99 & 0.98 & 0.96 \\
\hline 014-S1-RS05 & $\mathrm{M} / \mathrm{AA}$ & 0.99 & 0.98 & 0.97 & 1.00 & 0.99 & 0.97 \\
\hline 014-S1-RS05 & $\mathrm{M} / \mathrm{C}$ & 0.99 & 0.73 & 0.97 & 1.05 & 0.96 & 0.86 \\
\hline 014-S1-RS06 & $\mathrm{Bq}$ & $4.31 \mathrm{E}+6$ & $9.78 \mathrm{E}+4$ & $9.99 \mathrm{E}+5$ & $1.92 \mathrm{E}+6$ & $2.86 \mathrm{E}+7$ & $3.13 E+4$ \\
\hline 014-S1-RS06 & $\mathrm{M} / \mathrm{A}$ & 1.08 & 1.04 & 1.07 & 1.03 & 1.03 & 1.10 \\
\hline 014-S1-RS06 & M/AA & 1.05 & 1.01 & 1.04 & 1.00 & 1.00 & 1.07 \\
\hline 014-S1-RS06 & $\mathrm{M} / \mathrm{C}$ & 1.04 & 0.76 & 1.04 & 1.05 & 0.96 & 0.95 \\
\hline 014-S1-RS07 & $\mathrm{Bq}$ & $4.10 \mathrm{E}+6$ & $9.36 \mathrm{E}+4$ & $8.95 \mathrm{E}+5$ & $1.85 \mathrm{E}+6$ & $2.72 \mathrm{E}+7$ & $2.70 \mathrm{E}+4$ \\
\hline 014-S1-RS07 & M/A & 1.02 & 0.99 & 0.96 & 0.99 & 0.98 & 0.94 \\
\hline 014-S1-RS07 & M/AA & 1.04 & 1.01 & 0.97 & 1.00 & 1.00 & 0.96 \\
\hline 014-S1-RS07 & $\mathrm{M} / \mathrm{C}$ & 1.03 & 0.76 & 0.98 & 1.05 & 0.96 & 0.85 \\
\hline 014-S1-RS08 & $\mathrm{Bq}$ & $4.00 \mathrm{E}+6$ & $9.30 \mathrm{E}+4$ & $8.76 \mathrm{E}+5$ & $1.78 \mathrm{E}+6$ & $2.65 \mathrm{E}+7$ & $2.66 \mathrm{E}+4$ \\
\hline 014-S1-RS08 & $\mathrm{M} / \mathrm{A}$ & 1.00 & 0.98 & 0.94 & 0.95 & 0.95 & 0.93 \\
\hline 014-S1-RS08 & $\mathrm{M} / \mathrm{AA}$ & 1.05 & 1.03 & 0.98 & 1.00 & 1.00 & 0.98 \\
\hline 014-S1-RS08 & $\mathrm{M} / \mathrm{C}$ & 1.04 & 0.78 & 0.99 & 1.05 & 0.96 & 0.87 \\
\hline 014-S1-RS09 & $\mathrm{Bq}$ & $4.10 \mathrm{E}+6$ & $9.45 \mathrm{E}+4$ & $9.46 \mathrm{E}+5$ & $1.97 \mathrm{E}+6$ & $2.92 \mathrm{E}+7$ & $2.92 \mathrm{E}+4$ \\
\hline 014-S1-RS09 & $\mathrm{M} / \mathrm{A}$ & 1.02 & 1.00 & 1.01 & 1.05 & 1.05 & 1.02 \\
\hline 014-S1-RS09 & $\mathrm{M} / \mathrm{AA}$ & 0.97 & 0.95 & 0.96 & 1.00 & 1.00 & 0.97 \\
\hline 014-S1-RS09 & $\mathrm{M} / \mathrm{C}$ & 0.97 & 0.72 & 0.97 & 1.05 & 0.96 & 0.87 \\
\hline 014-S1-RS10 & $\mathrm{Bq}$ & $4.48 \mathrm{E}+6$ & $1.00 \mathrm{E}+5$ & $9.99 \mathrm{E}+5$ & $2.04 \mathrm{E}+6$ & $2.98 \mathrm{E}+7$ & $3.02 \mathrm{E}+4$ \\
\hline 014-S1-RS10 & $\mathrm{M} / \mathrm{A}$ & 1.12 & 1.06 & 1.07 & 1.09 & 1.07 & 1.06 \\
\hline 014-S1-RS10 & $\mathrm{M} / \mathrm{AA}$ & 1.03 & 0.98 & 0.98 & 1.00 & 0.98 & 0.97 \\
\hline 014-S1-RS10 & $\mathrm{M} / \mathrm{C}$ & 1.02 & 0.73 & 0.98 & 1.05 & 0.95 & 0.87 \\
\hline 014-S1-RS11 & $\mathrm{Bq}$ & $4.49 \mathrm{E}+6$ & $9.91 \mathrm{E}+4$ & $1.00 \mathrm{E}+6$ & $2.01 \mathrm{E}+6$ & $2.97 \mathrm{E}+7$ & $3.08 \mathrm{E}+4$ \\
\hline 014-S1-RS11 & $\mathrm{M} / \mathrm{A}$ & 1.12 & 1.05 & 1.07 & 1.07 & 1.07 & 1.08 \\
\hline 014-S1-RS11 & $\mathrm{M} / \mathrm{AA}$ & 1.05 & 0.98 & 1.00 & 1.00 & 1.00 & 1.01 \\
\hline 014-S1-RS11 & $\mathrm{M} / \mathrm{C}$ & 1.04 & 0.73 & 1.00 & 1.05 & 0.96 & 0.90 \\
\hline
\end{tabular}


Appendix Table B-1 continued. Radionuclide inventories of particles from AGR-3/4 Compact 1-4

\begin{tabular}{|c|c|c|c|c|c|c|c|}
\hline Particle & Value & ${ }^{106} \mathrm{Ru}$ & ${ }^{125} \mathrm{Sb}$ & ${ }^{134} \mathrm{Cs}$ & ${ }^{137} \mathrm{Cs}$ & ${ }^{144} \mathrm{Ce}$ & ${ }^{154} \mathbf{E u}$ \\
\hline 014-S1-RS12 & $\mathrm{Bq}$ & $3.99 E+6$ & $9.83 \mathrm{E}+4$ & $9.08 \mathrm{E}+5$ & $1.86 \mathrm{E}+6$ & $2.81 \mathrm{E}+7$ & $2.68 \mathrm{E}+4$ \\
\hline 014-S1-RS12 & $\mathrm{M} / \mathrm{A}$ & 1.00 & 1.04 & 0.97 & 1.00 & 1.01 & 0.94 \\
\hline 014-S1-RS12 & $\mathrm{M} / \mathrm{AA}$ & 1.00 & 1.05 & 0.98 & 1.00 & 1.02 & 0.94 \\
\hline 014-S1-RS12 & $\mathrm{M} / \mathrm{C}$ & 1.00 & 0.79 & 0.98 & 1.05 & 0.98 & 0.84 \\
\hline 014-S1-RS13 & $\mathrm{Bq}$ & $3.75 \mathrm{E}+6$ & $8.48 \mathrm{E}+4$ & $8.52 \mathrm{E}+5$ & $1.73 E+6$ & $2.53 \mathrm{E}+7$ & $2.57 \mathrm{E}+4$ \\
\hline 014-S1-RS13 & $\mathrm{M} / \mathrm{A}$ & 0.93 & 0.90 & 0.91 & 0.92 & 0.91 & 0.90 \\
\hline 014-S1-RS13 & $\mathrm{M} / \mathrm{AA}$ & 1.01 & 0.98 & 0.99 & 1.00 & 0.99 & 0.98 \\
\hline 014-S1-RS13 & $\mathrm{M} / \mathrm{C}$ & 1.01 & 0.73 & 0.99 & 1.05 & 0.95 & 0.87 \\
\hline 014-S1-RS14 & $\mathrm{Bq}$ & $3.95 E+6$ & $8.39 \mathrm{E}+4$ & $8.58 \mathrm{E}+5$ & $1.72 \mathrm{E}+6$ & $2.61 \mathrm{E}+7$ & $2.60 \mathrm{E}+4$ \\
\hline 014-S1-RS14 & $\mathrm{M} / \mathrm{A}$ & 0.99 & 0.89 & 0.92 & 0.92 & 0.94 & 0.91 \\
\hline 014-S1-RS14 & $\mathrm{M} / \mathrm{AA}$ & 1.07 & 0.97 & 1.00 & 1.00 & 1.02 & 0.99 \\
\hline 014-S1-RS14 & $\mathrm{M} / \mathrm{C}$ & 1.07 & 0.72 & 1.00 & 1.05 & 0.98 & 0.88 \\
\hline 014-S1-RS15 & $\mathrm{Bq}$ & $4.22 \mathrm{E}+6$ & $9.79 \mathrm{E}+4$ & $9.69 \mathrm{E}+5$ & $1.85 \mathrm{E}+6$ & $2.77 \mathrm{E}+7$ & $2.92 \mathrm{E}+4$ \\
\hline 014-S1-RS15 & $\mathrm{M} / \mathrm{A}$ & 1.05 & 1.04 & 1.04 & 0.99 & 1.00 & 1.02 \\
\hline 014-S1-RS15 & $\mathrm{M} / \mathrm{AA}$ & 1.07 & 1.05 & 1.05 & 1.00 & 1.01 & 1.04 \\
\hline 014-S1-RS15 & $\mathrm{M} / \mathrm{C}$ & 1.06 & 0.79 & 1.05 & 1.05 & 0.97 & 0.92 \\
\hline 014-S2-RS01 & $\mathrm{Bq}$ & $4.45 \mathrm{E}+6$ & $1.05 \mathrm{E}+5$ & $9.89 \mathrm{E}+5$ & $1.95 \mathrm{E}+6$ & $2.97 \mathrm{E}+7$ & $3.08 \mathrm{E}+4$ \\
\hline 014-S2-RS01 & $\mathrm{M} / \mathrm{A}$ & 1.11 & 1.11 & 1.06 & 1.04 & 1.07 & 1.08 \\
\hline 014-S2-RS01 & $\mathrm{M} / \mathrm{AA}$ & 1.07 & 1.07 & 1.02 & 1.00 & 1.03 & 1.04 \\
\hline 014-S2-RS01 & $\mathrm{M} / \mathrm{C}$ & 1.06 & 0.80 & 1.02 & 1.05 & 0.99 & 0.92 \\
\hline 014-S2-RS02 & $\mathrm{Bq}$ & $4.14 E+6$ & $9.91 \mathrm{E}+4$ & $9.74 \mathrm{E}+5$ & $1.94 \mathrm{E}+6$ & $2.96 \mathrm{E}+7$ & $3.06 \mathrm{E}+4$ \\
\hline 014-S2-RS02 & $\mathrm{M} / \mathrm{A}$ & 1.03 & 1.05 & 1.04 & 1.04 & 1.07 & 1.07 \\
\hline 014-S2-RS02 & $\mathrm{M} / \mathrm{AA}$ & 0.99 & 1.01 & 1.00 & 1.00 & 1.03 & 1.04 \\
\hline 014-S2-RS02 & $\mathrm{M} / \mathrm{C}$ & 0.99 & 0.76 & 1.01 & 1.05 & 0.99 & 0.92 \\
\hline 014-S2-RS03 & $\mathrm{Bq}$ & $4.11 \mathrm{E}+6$ & $9.98 \mathrm{E}+4$ & $9.56 \mathrm{E}+5$ & $1.98 \mathrm{E}+6$ & $2.87 \mathrm{E}+7$ & $2.88 \mathrm{E}+4$ \\
\hline 014-S2-RS03 & $\mathrm{M} / \mathrm{A}$ & 1.03 & 1.06 & 1.02 & 1.06 & 1.03 & 1.01 \\
\hline 014-S2-RS03 & $\mathrm{M} / \mathrm{AA}$ & 0.97 & 1.00 & 0.97 & 1.00 & 0.98 & 0.96 \\
\hline 014-S2-RS03 & $\mathrm{M} / \mathrm{C}$ & 0.97 & 0.75 & 0.97 & 1.05 & 0.94 & 0.85 \\
\hline 014-S2-RS04 & $\mathrm{Bq}$ & $4.01 \mathrm{E}+6$ & $9.14 \mathrm{E}+4$ & $9.27 \mathrm{E}+5$ & $1.86 \mathrm{E}+6$ & $2.65 \mathrm{E}+7$ & $2.85 \mathrm{E}+4$ \\
\hline 014-S2-RS04 & $\mathrm{M} / \mathrm{A}$ & 1.00 & 0.97 & 0.99 & 0.99 & 0.95 & 1.00 \\
\hline 014-S2-RS04 & $\mathrm{M} / \mathrm{AA}$ & 1.01 & 0.97 & 1.00 & 1.00 & 0.96 & 1.01 \\
\hline 014-S2-RS04 & $\mathrm{M} / \mathrm{C}$ & 1.00 & 0.73 & 1.00 & 1.05 & 0.92 & 0.90 \\
\hline 014-S2-RS05 & $\mathrm{Bq}$ & $5.00 \mathrm{E}+6$ & $1.13 \mathrm{E}+5$ & $1.15 \mathrm{E}+6$ & $2.24 \mathrm{E}+6$ & $3.21 \mathrm{E}+7$ & $3.49 \mathrm{E}+4$ \\
\hline 014-S2-RS05 & $\mathrm{M} / \mathrm{A}$ & 1.25 & 1.20 & 1.23 & 1.20 & 1.16 & 1.22 \\
\hline 014-S2-RS05 & $\mathrm{M} / \mathrm{AA}$ & 1.04 & 1.01 & 1.03 & 1.00 & 0.97 & 1.02 \\
\hline 014-S2-RS05 & $\mathrm{M} / \mathrm{C}$ & 1.04 & 0.75 & 1.03 & 1.05 & 0.93 & 0.91 \\
\hline 014-S2-RS06 & $\mathrm{Bq}$ & $4.40 \mathrm{E}+6$ & $9.80 \mathrm{E}+4$ & $1.01 \mathrm{E}+6$ & $1.94 \mathrm{E}+6$ & $2.86 \mathrm{E}+7$ & $3.07 \mathrm{E}+4$ \\
\hline 014-S2-RS06 & $\mathrm{M} / \mathrm{A}$ & 1.10 & 1.04 & 1.08 & 1.04 & 1.03 & 1.08 \\
\hline 014-S2-RS06 & $\mathrm{M} / \mathrm{AA}$ & 1.06 & 1.00 & 1.04 & 1.00 & 0.99 & 1.04 \\
\hline 014-S2-RS06 & $\mathrm{M} / \mathrm{C}$ & 1.05 & 0.75 & 1.04 & 1.05 & 0.96 & 0.92 \\
\hline 014-S2-RS07 & $\mathrm{Bq}$ & $4.33 \mathrm{E}+6$ & $1.04 \mathrm{E}+5$ & $1.00 \mathrm{E}+6$ & $1.99 \mathrm{E}+6$ & $2.96 \mathrm{E}+7$ & $3.08 \mathrm{E}+4$ \\
\hline 014-S2-RS07 & $\mathrm{M} / \mathrm{A}$ & 1.08 & 1.11 & 1.07 & 1.06 & 1.07 & 1.08 \\
\hline 014-S2-RS07 & $\mathrm{M} / \mathrm{AA}$ & 1.02 & 1.04 & 1.01 & 1.00 & 1.01 & 1.02 \\
\hline 014-S2-RS07 & $\mathrm{M} / \mathrm{C}$ & 1.01 & 0.78 & 1.01 & 1.05 & 0.97 & 0.91 \\
\hline 014-S2-RS08 & $\mathrm{Bq}$ & $4.72 \mathrm{E}+6$ & $1.07 \mathrm{E}+5$ & $1.11 \mathrm{E}+6$ & $2.21 \mathrm{E}+6$ & $3.25 \mathrm{E}+7$ & $3.39 \mathrm{E}+4$ \\
\hline 014-S2-RS08 & $\mathrm{M} / \mathrm{A}$ & 1.18 & 1.14 & 1.19 & 1.18 & 1.17 & 1.19 \\
\hline 014-S2-RS08 & $\mathrm{M} / \mathrm{AA}$ & 1.00 & 0.96 & 1.01 & 1.00 & 0.99 & 1.01 \\
\hline 014-S2-RS08 & $\mathrm{M} / \mathrm{C}$ & 0.99 & 0.72 & 1.01 & 1.05 & 0.96 & 0.90 \\
\hline
\end{tabular}


Appendix Table B-1 continued. Radionuclide inventories of particles from AGR-3/4 Compact 1-4

\begin{tabular}{|c|c|c|c|c|c|c|c|}
\hline Particle & Value & ${ }^{106} \mathrm{Ru}$ & ${ }^{125} \mathrm{Sb}$ & ${ }^{134} \mathrm{Cs}$ & ${ }^{137} \mathrm{Cs}$ & ${ }^{144} \mathrm{Ce}$ & ${ }^{154} \mathbf{E u}$ \\
\hline 014-S2-RS09 & $\mathrm{Bq}$ & $4.10 \mathrm{E}+6$ & $9.51 \mathrm{E}+4$ & $9.21 \mathrm{E}+5$ & $1.89 \mathrm{E}+6$ & $2.83 \mathrm{E}+7$ & $2.74 \mathrm{E}+4$ \\
\hline 014-S2-RS09 & $\mathrm{M} / \mathrm{A}$ & 1.02 & 1.01 & 0.98 & 1.01 & 1.02 & 0.96 \\
\hline 014-S2-RS09 & $\mathrm{M} / \mathrm{AA}$ & 1.01 & 1.00 & 0.97 & 1.00 & 1.01 & 0.95 \\
\hline 014-S2-RS09 & $\mathrm{M} / \mathrm{C}$ & 1.01 & 0.75 & 0.98 & 1.05 & 0.97 & 0.84 \\
\hline 014-S2-RS10 & $\mathrm{Bq}$ & $4.50 \mathrm{E}+6$ & $9.98 \mathrm{E}+4$ & $1.04 \mathrm{E}+6$ & $2.04 \mathrm{E}+6$ & $3.07 \mathrm{E}+7$ & $3.21 \mathrm{E}+4$ \\
\hline 014-S2-RS10 & $\mathrm{M} / \mathrm{A}$ & 1.12 & 1.06 & 1.12 & 1.09 & 1.11 & 1.13 \\
\hline 014-S2-RS10 & $\mathrm{M} / \mathrm{AA}$ & 1.03 & 0.97 & 1.03 & 1.00 & 1.02 & 1.04 \\
\hline 014-S2-RS10 & $\mathrm{M} / \mathrm{C}$ & 1.03 & 0.73 & 1.03 & 1.05 & 0.98 & 0.92 \\
\hline 014-S2-RS11 & $\mathrm{Bq}$ & $4.21 \mathrm{E}+6$ & $9.87 \mathrm{E}+4$ & $1.00 \mathrm{E}+6$ & $1.99 \mathrm{E}+6$ & $2.96 \mathrm{E}+7$ & $2.97 \mathrm{E}+4$ \\
\hline 014-S2-RS11 & $\mathrm{M} / \mathrm{A}$ & 1.05 & 1.05 & 1.07 & 1.06 & 1.06 & 1.04 \\
\hline 014-S2-RS11 & $\mathrm{M} / \mathrm{AA}$ & 0.99 & 0.99 & 1.01 & 1.00 & 1.00 & 0.98 \\
\hline 014-S2-RS11 & $\mathrm{M} / \mathrm{C}$ & 0.99 & 0.74 & 1.02 & 1.05 & 0.97 & 0.87 \\
\hline 014-S2-RS12 & $\mathrm{Bq}$ & $4.32 \mathrm{E}+6$ & $1.02 \mathrm{E}+5$ & $9.99 \mathrm{E}+5$ & $2.02 \mathrm{E}+6$ & $2.96 \mathrm{E}+7$ & $2.99 \mathrm{E}+4$ \\
\hline 014-S2-RS12 & $\mathrm{M} / \mathrm{A}$ & 1.08 & 1.08 & 1.07 & 1.08 & 1.07 & 1.05 \\
\hline 014-S2-RS12 & $\mathrm{M} / \mathrm{AA}$ & 1.00 & 1.00 & 0.99 & 1.00 & 0.99 & 0.97 \\
\hline 014-S2-RS12 & $\mathrm{M} / \mathrm{C}$ & 1.00 & 0.75 & 1.00 & 1.05 & 0.95 & 0.87 \\
\hline 014-S2-RS13 & $\mathrm{Bq}$ & $3.49 E+6$ & $8.07 \mathrm{E}+4$ & $8.14 \mathrm{E}+5$ & $1.66 \mathrm{E}+6$ & $2.47 \mathrm{E}+7$ & $2.43 \mathrm{E}+4$ \\
\hline 014-S2-RS13 & $\mathrm{M} / \mathrm{A}$ & 0.87 & 0.86 & 0.87 & 0.88 & 0.89 & 0.85 \\
\hline 014-S2-RS13 & $\mathrm{M} / \mathrm{AA}$ & 0.98 & 0.97 & 0.99 & 1.00 & 1.01 & 0.96 \\
\hline 014-S2-RS13 & $\mathrm{M} / \mathrm{C}$ & 0.98 & 0.73 & 0.99 & 1.05 & 0.97 & 0.86 \\
\hline 014-S2-RS14 & $\mathrm{Bq}$ & $4.97 E+6$ & $1.10 \mathrm{E}+5$ & $1.09 \mathrm{E}+6$ & $2.11 \mathrm{E}+6$ & $3.17 \mathrm{E}+7$ & $3.38 \mathrm{E}+4$ \\
\hline 014-S2-RS14 & $\mathrm{M} / \mathrm{A}$ & 1.24 & 1.16 & 1.17 & 1.13 & 1.14 & 1.18 \\
\hline 014-S2-RS14 & $\mathrm{M} / \mathrm{AA}$ & 1.10 & 1.03 & 1.03 & 1.00 & 1.01 & 1.05 \\
\hline 014-S2-RS14 & $\mathrm{M} / \mathrm{C}$ & 1.09 & 0.77 & 1.04 & 1.05 & 0.97 & 0.93 \\
\hline 014-S2-RS15 & $\mathrm{Bq}$ & $4.41 \mathrm{E}+6$ & $1.01 \mathrm{E}+5$ & $1.04 \mathrm{E}+6$ & $2.02 \mathrm{E}+6$ & $3.05 \mathrm{E}+7$ & $3.22 \mathrm{E}+4$ \\
\hline 014-S2-RS15 & $\mathrm{M} / \mathrm{A}$ & 1.10 & 1.07 & 1.11 & 1.08 & 1.10 & 1.13 \\
\hline 014-S2-RS15 & $\mathrm{M} / \mathrm{AA}$ & 1.02 & 0.99 & 1.03 & 1.00 & 1.02 & 1.05 \\
\hline 014-S2-RS15 & $\mathrm{M} / \mathrm{C}$ & 1.02 & 0.74 & 1.03 & 1.05 & 0.98 & 0.93 \\
\hline 014-S3-RS01 & $\mathrm{Bq}$ & $3.26 \mathrm{E}+6$ & $8.28 \mathrm{E}+4$ & $7.68 \mathrm{E}+5$ & $1.58 \mathrm{E}+6$ & $2.34 \mathrm{E}+7$ & $2.28 \mathrm{E}+4$ \\
\hline 014-S3-RS01 & $\mathrm{M} / \mathrm{A}$ & 0.81 & 0.88 & 0.82 & 0.84 & 0.84 & 0.80 \\
\hline 014-S3-RS01 & $\mathrm{M} / \mathrm{AA}$ & 0.97 & 1.04 & 0.98 & 1.00 & 1.00 & 0.95 \\
\hline 014-S3-RS01 & $\mathrm{M} / \mathrm{C}$ & 0.96 & 0.78 & 0.98 & 1.05 & 0.96 & 0.84 \\
\hline 014-S3-RS02 & $\mathrm{Bq}$ & $3.63 \mathrm{E}+6$ & $8.33 \mathrm{E}+4$ & $8.56 \mathrm{E}+5$ & $1.74 \mathrm{E}+6$ & $2.58 \mathrm{E}+7$ & $2.61 \mathrm{E}+4$ \\
\hline 014-S3-RS02 & $\mathrm{M} / \mathrm{A}$ & 0.91 & 0.88 & 0.92 & 0.93 & 0.93 & 0.91 \\
\hline 014-S3-RS02 & $\mathrm{M} / \mathrm{AA}$ & 0.98 & 0.95 & 0.99 & 1.00 & 1.00 & 0.99 \\
\hline 014-S3-RS02 & $\mathrm{M} / \mathrm{C}$ & 0.97 & 0.71 & 0.99 & 1.05 & 0.97 & 0.88 \\
\hline 014-S3-RS03 & $\mathrm{Bq}$ & $3.81 \mathrm{E}+6$ & $8.73 \mathrm{E}+4$ & $9.25 \mathrm{E}+5$ & $1.82 \mathrm{E}+6$ & $2.79 \mathrm{E}+7$ & $2.80 \mathrm{E}+4$ \\
\hline 014-S3-RS03 & $\mathrm{M} / \mathrm{A}$ & 0.95 & 0.92 & 0.99 & 0.97 & 1.01 & 0.98 \\
\hline 014-S3-RS03 & $\mathrm{M} / \mathrm{AA}$ & 0.98 & 0.95 & 1.02 & 1.00 & 1.03 & 1.01 \\
\hline 014-S3-RS03 & $\mathrm{M} / \mathrm{C}$ & 0.97 & 0.71 & 1.02 & 1.05 & 0.99 & 0.90 \\
\hline 014-S3-RS04 & $\mathrm{Bq}$ & $4.04 \mathrm{E}+6$ & $9.40 \mathrm{E}+4$ & $9.49 \mathrm{E}+5$ & $1.85 \mathrm{E}+6$ & $2.73 \mathrm{E}+7$ & $2.98 \mathrm{E}+4$ \\
\hline 014-S3-RS04 & $\mathrm{M} / \mathrm{A}$ & 1.01 & 1.00 & 1.01 & 0.99 & 0.98 & 1.04 \\
\hline 014-S3-RS04 & $\mathrm{M} / \mathrm{AA}$ & 1.02 & 1.01 & 1.03 & 1.00 & 1.00 & 1.06 \\
\hline 014-S3-RS04 & $\mathrm{M} / \mathrm{C}$ & 1.02 & 0.76 & 1.03 & 1.05 & 0.96 & 0.94 \\
\hline 014-S3-RS05 & $\mathrm{Bq}$ & $3.78 \mathrm{E}+6$ & $9.34 \mathrm{E}+4$ & $9.20 \mathrm{E}+5$ & $1.87 \mathrm{E}+6$ & $2.77 \mathrm{E}+7$ & $2.78 \mathrm{E}+4$ \\
\hline 014-S3-RS05 & $\mathrm{M} / \mathrm{A}$ & 0.94 & 0.99 & 0.98 & 1.00 & 1.00 & 0.98 \\
\hline 014-S3-RS05 & $\mathrm{M} / \mathrm{AA}$ & 0.95 & 0.99 & 0.99 & 1.00 & 1.00 & 0.98 \\
\hline 014-S3-RS05 & $\mathrm{M} / \mathrm{C}$ & 0.94 & 0.75 & 0.99 & 1.05 & 0.96 & 0.87 \\
\hline
\end{tabular}


Appendix Table B-1 continued. Radionuclide inventories of particles from AGR-3/4 Compact 1-4

\begin{tabular}{|c|c|c|c|c|c|c|c|}
\hline Particle & Value & ${ }^{106} \mathrm{Ru}$ & ${ }^{125} \mathrm{Sb}$ & ${ }^{134} \mathrm{Cs}$ & ${ }^{137} \mathrm{Cs}$ & ${ }^{144} \mathrm{Ce}$ & ${ }^{154} \mathbf{E u}$ \\
\hline 014-S3-RS06 & $\mathrm{Bq}$ & $3.61 \mathrm{E}+6$ & $9.39 \mathrm{E}+4$ & $8.38 \mathrm{E}+5$ & $1.69 \mathrm{E}+6$ & $2.53 \mathrm{E}+7$ & $2.61 \mathrm{E}+4$ \\
\hline 014-S3-RS06 & $\mathrm{M} / \mathrm{A}$ & 0.90 & 0.99 & 0.90 & 0.90 & 0.91 & 0.92 \\
\hline 014-S3-RS06 & $\mathrm{M} / \mathrm{AA}$ & 1.00 & 1.10 & 0.99 & 1.00 & 1.01 & 1.02 \\
\hline 014-S3-RS06 & $\mathrm{M} / \mathrm{C}$ & 1.00 & 0.83 & 1.00 & 1.05 & 0.97 & 0.90 \\
\hline 014-S3-RS07 & $\mathrm{Bq}$ & $3.60 \mathrm{E}+6$ & $8.13 \mathrm{E}+4$ & $8.33 \mathrm{E}+5$ & $1.70 \mathrm{E}+6$ & $2.59 \mathrm{E}+7$ & $2.47 \mathrm{E}+4$ \\
\hline 014-S3-RS07 & $\mathrm{M} / \mathrm{A}$ & 0.90 & 0.86 & 0.89 & 0.91 & 0.93 & 0.87 \\
\hline 014-S3-RS07 & $\mathrm{M} / \mathrm{AA}$ & 0.99 & 0.95 & 0.98 & 1.00 & 1.03 & 0.96 \\
\hline 014-S3-RS07 & $\mathrm{M} / \mathrm{C}$ & 0.99 & 0.71 & 0.99 & 1.05 & 0.99 & 0.85 \\
\hline 014-S3-RS08 & $\mathrm{Bq}$ & $4.05 \mathrm{E}+6$ & $9.09 \mathrm{E}+4$ & $9.27 \mathrm{E}+5$ & $1.79 \mathrm{E}+6$ & $2.65 \mathrm{E}+7$ & $2.86 \mathrm{E}+4$ \\
\hline 014-S3-RS08 & $\mathrm{M} / \mathrm{A}$ & 1.01 & 0.96 & 0.99 & 0.95 & 0.96 & 1.00 \\
\hline 014-S3-RS08 & $\mathrm{M} / \mathrm{AA}$ & 1.06 & 1.01 & 1.04 & 1.00 & 1.00 & 1.05 \\
\hline 014-S3-RS08 & $\mathrm{M} / \mathrm{C}$ & 1.06 & 0.76 & 1.04 & 1.05 & 0.96 & 0.94 \\
\hline 014-S3-RS09 & $\mathrm{Bq}$ & $3.36 \mathrm{E}+6$ & $8.43 \mathrm{E}+4$ & $8.21 \mathrm{E}+5$ & $1.65 \mathrm{E}+6$ & $2.50 \mathrm{E}+7$ & $2.48 \mathrm{E}+4$ \\
\hline 014-S3-RS09 & $\mathrm{M} / \mathrm{A}$ & 0.84 & 0.89 & 0.88 & 0.88 & 0.90 & 0.87 \\
\hline 014-S3-RS09 & $\mathrm{M} / \mathrm{AA}$ & 0.95 & 1.01 & 0.99 & 1.00 & 1.02 & 0.98 \\
\hline 014-S3-RS09 & $\mathrm{M} / \mathrm{C}$ & 0.95 & 0.76 & 1.00 & 1.05 & 0.98 & 0.88 \\
\hline 014-S3-RS10 & $\mathrm{Bq}$ & $3.70 \mathrm{E}+6$ & $9.03 \mathrm{E}+4$ & $8.93 \mathrm{E}+5$ & $1.82 \mathrm{E}+6$ & $2.66 \mathrm{E}+7$ & $2.69 \mathrm{E}+4$ \\
\hline 014-S3-RS10 & $\mathrm{M} / \mathrm{A}$ & 0.92 & 0.96 & 0.96 & 0.97 & 0.96 & 0.94 \\
\hline 014-S3-RS10 & $\mathrm{M} / \mathrm{AA}$ & 0.95 & 0.99 & 0.98 & 1.00 & 0.99 & 0.97 \\
\hline 014-S3-RS10 & $\mathrm{M} / \mathrm{C}$ & 0.95 & 0.74 & 0.99 & 1.05 & 0.95 & 0.87 \\
\hline 014-S3-RS11 & $\mathrm{Bq}$ & $3.70 \mathrm{E}+6$ & $8.61 \mathrm{E}+4$ & $8.67 \mathrm{E}+5$ & $1.77 \mathrm{E}+6$ & $2.71 \mathrm{E}+7$ & $2.64 \mathrm{E}+4$ \\
\hline 014-S3-RS11 & $\mathrm{M} / \mathrm{A}$ & 0.92 & 0.91 & 0.93 & 0.94 & 0.98 & 0.93 \\
\hline 014-S3-RS11 & $\mathrm{M} / \mathrm{AA}$ & 0.98 & 0.97 & 0.98 & 1.00 & 1.03 & 0.98 \\
\hline 014-S3-RS11 & $\mathrm{M} / \mathrm{C}$ & 0.98 & 0.73 & 0.99 & 1.05 & 1.00 & 0.87 \\
\hline 014-S3-RS12 & $\mathrm{Bq}$ & $3.28 \mathrm{E}+6$ & $8.30 \mathrm{E}+4$ & $8.09 \mathrm{E}+5$ & $1.61 \mathrm{E}+6$ & $2.47 \mathrm{E}+7$ & $2.45 \mathrm{E}+4$ \\
\hline 014-S3-RS12 & $\mathrm{M} / \mathrm{A}$ & 0.82 & 0.88 & 0.87 & 0.86 & 0.89 & 0.86 \\
\hline 014-S3-RS12 & $\mathrm{M} / \mathrm{AA}$ & 0.95 & 1.02 & 1.01 & 1.00 & 1.03 & 1.00 \\
\hline 014-S3-RS12 & $\mathrm{M} / \mathrm{C}$ & 0.95 & 0.77 & 1.01 & 1.05 & 1.00 & 0.89 \\
\hline 014-S3-RS13 & $\mathrm{Bq}$ & $3.92 \mathrm{E}+6$ & $9.64 \mathrm{E}+4$ & $9.22 \mathrm{E}+5$ & $1.87 \mathrm{E}+6$ & $2.79 \mathrm{E}+7$ & $2.80 \mathrm{E}+4$ \\
\hline 014-S3-RS13 & $\mathrm{M} / \mathrm{A}$ & 0.98 & 1.02 & 0.99 & 1.00 & 1.01 & 0.98 \\
\hline 014-S3-RS13 & $\mathrm{M} / \mathrm{AA}$ & 0.98 & 1.02 & 0.99 & 1.00 & 1.01 & 0.98 \\
\hline 014-S3-RS13 & $\mathrm{M} / \mathrm{C}$ & 0.98 & 0.77 & 0.99 & 1.05 & 0.97 & 0.88 \\
\hline 014-S3-RS14 & $\mathrm{Bq}$ & $3.62 \mathrm{E}+6$ & $8.96 \mathrm{E}+4$ & $8.80 \mathrm{E}+5$ & $1.80 \mathrm{E}+6$ & $2.67 \mathrm{E}+7$ & $2.67 \mathrm{E}+4$ \\
\hline 014-S3-RS14 & $\mathrm{M} / \mathrm{A}$ & 0.90 & 0.95 & 0.94 & 0.96 & 0.96 & 0.93 \\
\hline 014-S3-RS14 & $\mathrm{M} / \mathrm{AA}$ & 0.94 & 0.98 & 0.98 & 1.00 & 1.00 & 0.97 \\
\hline 014-S3-RS14 & $\mathrm{M} / \mathrm{C}$ & 0.93 & 0.74 & 0.98 & 1.05 & 0.96 & 0.86 \\
\hline 014-S3-RS15 & $\mathrm{Bq}$ & $3.06 \mathrm{E}+6$ & $8.13 \mathrm{E}+4$ & $7.51 \mathrm{E}+5$ & $1.56 \mathrm{E}+6$ & $2.34 \mathrm{E}+7$ & $2.28 \mathrm{E}+4$ \\
\hline 014-S3-RS15 & $\mathrm{M} / \mathrm{A}$ & 0.76 & 0.86 & 0.80 & 0.83 & 0.84 & 0.80 \\
\hline 014-S3-RS15 & $\mathrm{M} / \mathrm{AA}$ & 0.92 & 1.04 & 0.97 & 1.00 & 1.01 & 0.96 \\
\hline 014-S3-RS15 & $\mathrm{M} / \mathrm{C}$ & 0.92 & 0.78 & 0.97 & 1.05 & 0.98 & 0.86 \\
\hline 014-S4-RS01 & $\mathrm{Bq}$ & $4.75 E+6$ & $1.11 \mathrm{E}+5$ & $1.08 \mathrm{E}+6$ & $2.11 \mathrm{E}+6$ & $3.10 \mathrm{E}+7$ & $3.36 \mathrm{E}+4$ \\
\hline 014-S4-RS01 & $\mathrm{M} / \mathrm{A}$ & 1.19 & 1.18 & 1.16 & 1.13 & 1.11 & 1.18 \\
\hline 014-S4-RS01 & $\mathrm{M} / \mathrm{AA}$ & 1.05 & 1.05 & 1.03 & 1.00 & 0.99 & 1.05 \\
\hline 014-S4-RS01 & $\mathrm{M} / \mathrm{C}$ & 1.05 & 0.79 & 1.03 & 1.05 & 0.95 & 0.93 \\
\hline 014-S4-RS02 & $\mathrm{Bq}$ & $3.68 \mathrm{E}+6$ & $8.45 \mathrm{E}+4$ & $8.69 \mathrm{E}+5$ & $1.80 \mathrm{E}+6$ & $2.72 \mathrm{E}+7$ & $2.65 \mathrm{E}+4$ \\
\hline 014-S4-RS02 & $\mathrm{M} / \mathrm{A}$ & 0.92 & 0.89 & 0.93 & 0.96 & 0.98 & 0.93 \\
\hline 014-S4-RS02 & $\mathrm{M} / \mathrm{AA}$ & 0.95 & 0.93 & 0.97 & 1.00 & 1.02 & 0.97 \\
\hline 014-S4-RS02 & $\mathrm{M} / \mathrm{C}$ & 0.95 & 0.70 & 0.97 & 1.05 & 0.98 & 0.86 \\
\hline
\end{tabular}


Appendix Table B-1 continued. Radionuclide inventories of particles from AGR-3/4 Compact 1-4

\begin{tabular}{|c|c|c|c|c|c|c|c|}
\hline Particle & Value & ${ }^{106} \mathrm{Ru}$ & ${ }^{125} \mathrm{Sb}$ & ${ }^{134} \mathrm{Cs}$ & ${ }^{137} \mathrm{Cs}$ & ${ }^{144} \mathrm{Ce}$ & ${ }^{154} \mathbf{E u}$ \\
\hline 014-S4-RS03 & $\mathrm{Bq}$ & $4.23 \mathrm{E}+6$ & $8.88 \mathrm{E}+4$ & $9.68 \mathrm{E}+5$ & $1.89 \mathrm{E}+6$ & $2.75 \mathrm{E}+7$ & $3.02 \mathrm{E}+4$ \\
\hline 014-S4-RS03 & $\mathrm{M} / \mathrm{A}$ & 1.06 & 0.94 & 1.04 & 1.01 & 0.99 & 1.06 \\
\hline 014-S4-RS03 & $\mathrm{M} / \mathrm{AA}$ & 1.05 & 0.93 & 1.03 & 1.00 & 0.98 & 1.05 \\
\hline 014-S4-RS03 & $\mathrm{M} / \mathrm{C}$ & 1.04 & 0.70 & 1.03 & 1.05 & 0.95 & 0.94 \\
\hline 014-S4-RS04 & $\mathrm{Bq}$ & $3.97 \mathrm{E}+6$ & $1.03 \mathrm{E}+5$ & $9.65 \mathrm{E}+5$ & $1.94 \mathrm{E}+6$ & $2.87 \mathrm{E}+7$ & $3.04 \mathrm{E}+4$ \\
\hline 014-S4-RS04 & $\mathrm{M} / \mathrm{A}$ & 0.99 & 1.09 & 1.03 & 1.03 & 1.03 & 1.07 \\
\hline 014-S4-RS04 & $\mathrm{M} / \mathrm{AA}$ & 0.96 & 1.05 & 1.00 & 1.00 & 1.00 & 1.03 \\
\hline 014-S4-RS04 & $\mathrm{M} / \mathrm{C}$ & 0.95 & 0.79 & 1.00 & 1.05 & 0.96 & 0.92 \\
\hline 014-S4-RS05 & $\mathrm{Bq}$ & $3.77 \mathrm{E}+6$ & $8.83 \mathrm{E}+4$ & $9.21 \mathrm{E}+5$ & $1.84 \mathrm{E}+6$ & $2.68 \mathrm{E}+7$ & $2.73 \mathrm{E}+4$ \\
\hline 014-S4-RS05 & $\mathrm{M} / \mathrm{A}$ & 0.94 & 0.94 & 0.99 & 0.98 & 0.96 & 0.96 \\
\hline 014-S4-RS05 & $\mathrm{M} / \mathrm{AA}$ & 0.96 & 0.95 & 1.00 & 1.00 & 0.98 & 0.97 \\
\hline 014-S4-RS05 & $\mathrm{M} / \mathrm{C}$ & 0.95 & 0.71 & 1.01 & 1.05 & 0.95 & 0.87 \\
\hline 014-S4-RS06 & $\mathrm{Bq}$ & $3.90 \mathrm{E}+6$ & $1.02 \mathrm{E}+5$ & $9.50 \mathrm{E}+5$ & $1.92 \mathrm{E}+6$ & $2.82 \mathrm{E}+7$ & $2.89 \mathrm{E}+4$ \\
\hline 014-S4-RS06 & $\mathrm{M} / \mathrm{A}$ & 0.97 & 1.08 & 1.02 & 1.03 & 1.02 & 1.01 \\
\hline 014-S4-RS06 & $\mathrm{M} / \mathrm{AA}$ & 0.95 & 1.06 & 0.99 & 1.00 & 0.99 & 0.99 \\
\hline 014-S4-RS06 & $\mathrm{M} / \mathrm{C}$ & 0.94 & 0.79 & 0.99 & 1.05 & 0.95 & 0.88 \\
\hline 014-S4-RS07 & $\mathrm{Bq}$ & $4.04 \mathrm{E}+6$ & $9.80 \mathrm{E}+4$ & $9.76 \mathrm{E}+5$ & $1.96 \mathrm{E}+6$ & $2.88 \mathrm{E}+7$ & $3.03 \mathrm{E}+4$ \\
\hline 014-S4-RS07 & $\mathrm{M} / \mathrm{A}$ & 1.01 & 1.04 & 1.04 & 1.05 & 1.04 & 1.06 \\
\hline 014-S4-RS07 & $\mathrm{M} / \mathrm{AA}$ & 0.96 & 0.99 & 1.00 & 1.00 & 0.99 & 1.02 \\
\hline 014-S4-RS07 & $\mathrm{M} / \mathrm{C}$ & 0.96 & 0.74 & 1.00 & 1.05 & 0.95 & 0.90 \\
\hline 014-S4-RS08 & $\mathrm{Bq}$ & $3.72 \mathrm{E}+6$ & $9.74 \mathrm{E}+4$ & $9.14 \mathrm{E}+5$ & $1.80 \mathrm{E}+6$ & $2.68 \mathrm{E}+7$ & $2.79 \mathrm{E}+4$ \\
\hline 014-S4-RS08 & $\mathrm{M} / \mathrm{A}$ & 0.93 & 1.03 & 0.98 & 0.96 & 0.96 & 0.98 \\
\hline 014-S4-RS08 & $\mathrm{M} / \mathrm{AA}$ & 0.96 & 1.07 & 1.01 & 1.00 & 1.00 & 1.02 \\
\hline 014-S4-RS08 & $\mathrm{M} / \mathrm{C}$ & 0.96 & 0.80 & 1.02 & 1.05 & 0.96 & 0.90 \\
\hline 014-S4-RS09 & $\mathrm{Bq}$ & $4.35 \mathrm{E}+6$ & $1.03 \mathrm{E}+5$ & $1.07 \mathrm{E}+6$ & $2.13 \mathrm{E}+6$ & $3.09 \mathrm{E}+7$ & $3.24 \mathrm{E}+4$ \\
\hline 014-S4-RS09 & $\mathrm{M} / \mathrm{A}$ & 1.08 & 1.09 & 1.15 & 1.14 & 1.11 & 1.13 \\
\hline 014-S4-RS09 & $\mathrm{M} / \mathrm{AA}$ & 0.95 & 0.96 & 1.01 & 1.00 & 0.98 & 1.00 \\
\hline 014-S4-RS09 & $\mathrm{M} / \mathrm{C}$ & 0.95 & 0.72 & 1.01 & 1.05 & 0.94 & 0.89 \\
\hline 014-S4-RS10 & $\mathrm{Bq}$ & $4.25 \mathrm{E}+6$ & $9.91 \mathrm{E}+4$ & $9.82 \mathrm{E}+5$ & $1.96 \mathrm{E}+6$ & $2.85 \mathrm{E}+7$ & $3.02 \mathrm{E}+4$ \\
\hline 014-S4-RS10 & $\mathrm{M} / \mathrm{A}$ & 1.06 & 1.05 & 1.05 & 1.05 & 1.03 & 1.06 \\
\hline 014-S4-RS10 & $\mathrm{M} / \mathrm{AA}$ & 1.01 & 1.00 & 1.00 & 1.00 & 0.98 & 1.01 \\
\hline 014-S4-RS10 & $\mathrm{M} / \mathrm{C}$ & 1.01 & 0.75 & 1.00 & 1.05 & 0.94 & 0.90 \\
\hline 014-S4-RS11 & $\mathrm{Bq}$ & $3.78 \mathrm{E}+6$ & $9.17 \mathrm{E}+4$ & $9.36 \mathrm{E}+5$ & $1.87 \mathrm{E}+6$ & $2.75 \mathrm{E}+7$ & $2.91 \mathrm{E}+4$ \\
\hline 014-S4-RS11 & $\mathrm{M} / \mathrm{A}$ & 0.94 & 0.97 & 1.00 & 1.00 & 0.99 & 1.02 \\
\hline 014-S4-RS11 & $\mathrm{M} / \mathrm{AA}$ & 0.95 & 0.97 & 1.00 & 1.00 & 0.99 & 1.02 \\
\hline 014-S4-RS11 & $\mathrm{M} / \mathrm{C}$ & 0.94 & 0.73 & 1.01 & 1.05 & 0.95 & 0.91 \\
\hline 014-S4-RS12 & $\mathrm{Bq}$ & $4.43 \mathrm{E}+6$ & $1.05 \mathrm{E}+5$ & $1.02 \mathrm{E}+6$ & $2.04 \mathrm{E}+6$ & $2.99 \mathrm{E}+7$ & $3.09 \mathrm{E}+4$ \\
\hline 014-S4-RS12 & $\mathrm{M} / \mathrm{A}$ & 1.10 & 1.11 & 1.09 & 1.09 & 1.08 & 1.08 \\
\hline 014-S4-RS12 & $\mathrm{M} / \mathrm{AA}$ & 1.01 & 1.02 & 1.01 & 1.00 & 0.99 & 0.99 \\
\hline 014-S4-RS12 & $\mathrm{M} / \mathrm{C}$ & 1.01 & 0.76 & 1.01 & 1.05 & 0.95 & 0.89 \\
\hline 014-S4-RS13 & $\mathrm{Bq}$ & $3.57 \mathrm{E}+6$ & $8.40 \mathrm{E}+4$ & $8.22 \mathrm{E}+5$ & $1.71 \mathrm{E}+6$ & $2.43 \mathrm{E}+7$ & $2.52 \mathrm{E}+4$ \\
\hline 014-S4-RS13 & $\mathrm{M} / \mathrm{A}$ & 0.89 & 0.89 & 0.88 & 0.91 & 0.88 & 0.88 \\
\hline 014-S4-RS13 & $\mathrm{M} / \mathrm{AA}$ & 0.98 & 0.98 & 0.96 & 1.00 & 0.96 & 0.97 \\
\hline 014-S4-RS13 & $\mathrm{M} / \mathrm{C}$ & 0.97 & 0.73 & 0.97 & 1.05 & 0.93 & 0.86 \\
\hline 014-S4-RS14 & $\mathrm{Bq}$ & $3.32 \mathrm{E}+6$ & $8.03 \mathrm{E}+4$ & $8.20 \mathrm{E}+5$ & $1.66 \mathrm{E}+6$ & $2.43 \mathrm{E}+7$ & $2.51 \mathrm{E}+4$ \\
\hline 014-S4-RS14 & $\mathrm{M} / \mathrm{A}$ & 0.83 & 0.85 & 0.88 & 0.88 & 0.87 & 0.88 \\
\hline 014-S4-RS14 & $\mathrm{M} / \mathrm{AA}$ & 0.94 & 0.96 & 0.99 & 1.00 & 0.99 & 1.00 \\
\hline 014-S4-RS14 & $\mathrm{M} / \mathrm{C}$ & 0.93 & 0.72 & 1.00 & 1.05 & 0.95 & 0.89 \\
\hline
\end{tabular}


Appendix Table B-1 continued. Radionuclide inventories of particles from AGR-3/4 Compact 1-4

\begin{tabular}{lccccccc}
\hline Particle & Value & ${ }^{\mathbf{1 0 6}} \mathbf{R u}$ & ${ }^{\mathbf{1 2 5}} \mathbf{S b}$ & ${ }^{\mathbf{1 3 4}} \mathbf{C s}$ & ${ }^{{ }^{37} \mathbf{C s}}$ & ${ }^{144} \mathbf{C e}$ & ${ }^{154} \mathbf{E u}$ \\
\hline 014-S4-RS15 & $\mathrm{Bq}$ & $3.80 \mathrm{E}+6$ & $9.20 \mathrm{E}+4$ & $9.18 \mathrm{E}+5$ & $1.91 \mathrm{E}+6$ & $2.75 \mathrm{E}+7$ & $2.87 \mathrm{E}+4$ \\
014-S4-RS15 & $\mathrm{M} / \mathrm{A}$ & 0.95 & 0.97 & 0.98 & 1.02 & 0.99 & 1.01 \\
014-S4-RS15 & $\mathrm{M} / \mathrm{AA}$ & 0.93 & 0.95 & 0.96 & 1.00 & 0.97 & 0.99 \\
014-S4-RS15 & $\mathrm{M} / \mathrm{C}$ & 0.92 & 0.72 & 0.96 & 1.05 & 0.93 & 0.88 \\
\hline Maximum & $\mathrm{Bq}$ & $5.00 \mathrm{E}+6$ & $1.13 \mathrm{E}+5$ & $1.15 \mathrm{E}+6$ & $2.24 \mathrm{E}+6$ & $3.25 \mathrm{E}+7$ & $3.49 \mathrm{E}+4$ \\
Maximum & $\mathrm{M} / \mathrm{A}$ & 1.25 & 1.20 & 1.23 & 1.20 & 1.17 & 1.22 \\
Maximum & $\mathrm{M} / \mathrm{AA}$ & 1.10 & 1.10 & 1.05 & 1.00 & 1.03 & 1.07 \\
Maximum & $\mathrm{M} / \mathrm{C}$ & 1.09 & 0.83 & 1.05 & 1.05 & 1.00 & 0.96 \\
Minimum & $\mathrm{Bq}$ & $3.06 \mathrm{E}+6$ & $8.03 \mathrm{E}+4$ & $7.51 \mathrm{E}+5$ & $1.56 \mathrm{E}+6$ & $2.34 \mathrm{E}+7$ & $2.28 \mathrm{E}+4$ \\
Minimum & $\mathrm{M} / \mathrm{A}$ & 0.76 & 0.85 & 0.80 & 0.83 & 0.84 & 0.80 \\
Minimum & $\mathrm{M} / \mathrm{AA}$ & 0.92 & 0.93 & 0.96 & 1.00 & 0.96 & 0.94 \\
Minimum & $\mathrm{M} / \mathrm{C}$ & 0.92 & 0.70 & 0.96 & 1.05 & 0.92 & 0.84 \\
Mean & $\mathrm{Bq}$ & $4.01 \mathrm{E}+6$ & $9.44 \mathrm{E}+4$ & $9.35 \mathrm{E}+5$ & $1.87 \mathrm{E}+6$ & $2.78 \mathrm{E}+7$ & $2.85 \mathrm{E}+4$ \\
Mean & $\mathrm{M} / \mathrm{A}$ & 1.00 & 1.00 & 1.00 & 1.00 & 1.00 & 1.00 \\
Mean & $\mathrm{M} / \mathrm{AA}$ & 1.00 & 1.00 & 1.00 & 1.00 & 1.00 & 1.00 \\
Mean & $\mathrm{M} / \mathrm{C}$ & 0.99 & 0.75 & 1.00 & 1.05 & 0.96 & 0.89 \\
SD & $\mathrm{Bq}$ & $10.5 \%$ & $8.7 \%$ & $9.2 \%$ & $8.1 \%$ & $7.7 \%$ & $9.9 \%$ \\
SD & $\mathrm{M} / \mathrm{A}$ & $10.5 \%$ & $8.7 \%$ & $9.2 \%$ & $8.1 \%$ & $7.7 \%$ & $9.9 \%$ \\
SD & $\mathrm{M} / \mathrm{AA}$ & $4.3 \%$ & $3.8 \%$ & $2.3 \%$ & $0.0 \%$ & $1.7 \%$ & $3.3 \%$ \\
SD & $\mathrm{M} / \mathrm{C}$ & $4.3 \%$ & $3.8 \%$ & $2.3 \%$ & $0.0 \%$ & $1.7 \%$ & $3.3 \%$ \\
\hline
\end{tabular}


Appendix Table B-2. Radionuclide inventories of particles from AGR-3/4 Compact 10-4

\begin{tabular}{|c|c|c|c|c|c|c|c|}
\hline Particle & Value & ${ }^{106} \mathrm{Ru}$ & ${ }^{125} \mathrm{Sb}$ & ${ }^{134} \mathrm{Cs}$ & ${ }^{137} \mathrm{Cs}$ & ${ }^{144} \mathrm{Ce}$ & ${ }^{154} \mathbf{E u}$ \\
\hline 104-S1-SP01 & $\mathrm{Bq}$ & $0.00 \mathrm{E}+0$ & $0.00 \mathrm{E}+0$ & $0.00 \mathrm{E}+0$ & $0.00 \mathrm{E}+0$ & $0.00 \mathrm{E}+0$ & $0.00 \mathrm{E}+0$ \\
\hline 104-S1-SP01 & $\mathrm{M} / \mathrm{A}$ & 0.00 & 0.00 & 0.00 & 0.00 & 0.00 & 0.00 \\
\hline 104-S1-SP01 & M/AA & & & & & & \\
\hline 104-S1-SP01 & $\mathrm{M} / \mathrm{C}$ & & & & & & \\
\hline 104-S1-SP02 & $\mathrm{Bq}$ & $1.04 \mathrm{E}+7$ & $2.09 \mathrm{E}+5$ & $4.08 \mathrm{E}+6$ & $4.67 \mathrm{E}+6$ & $3.15 \mathrm{E}+7$ & $1.43 \mathrm{E}+5$ \\
\hline 104-S1-SP02 & $\mathrm{M} / \mathrm{A}$ & 1.08 & 1.32 & 1.49 & 1.55 & 0.65 & 1.80 \\
\hline 104-S1-SP02 & M/AA & 0.70 & 0.85 & 0.96 & 1.00 & 0.42 & 1.17 \\
\hline 104-S1-SP02 & $\mathrm{M} / \mathrm{C}$ & 0.77 & 0.60 & 0.93 & 1.01 & 0.44 & 0.99 \\
\hline 104-S3-SP01 & $\mathrm{Bq}$ & $3.30 \mathrm{E}+5$ & $0.00 \mathrm{E}+0$ & $0.00 \mathrm{E}+0$ & $0.00 \mathrm{E}+0$ & $1.74 \mathrm{E}+7$ & $0.00 \mathrm{E}+0$ \\
\hline 104-S3-SP01 & $\mathrm{M} / \mathrm{A}$ & 0.03 & 0.00 & 0.00 & 0.00 & 0.36 & 0.00 \\
\hline 104-S3-SP01 & M/AA & & & & & & \\
\hline 104-S3-SP01 & $\mathrm{M} / \mathrm{C}$ & & & & & & \\
\hline 104-S3-SP02 & $\mathrm{Bq}$ & $4.47 \mathrm{E}+5$ & $0.00 \mathrm{E}+0$ & $0.00 \mathrm{E}+0$ & $0.00 \mathrm{E}+0$ & $1.92 \mathrm{E}+7$ & $0.00 \mathrm{E}+0$ \\
\hline 104-S3-SP02 & $\mathrm{M} / \mathrm{A}$ & 0.05 & 0.00 & 0.00 & 0.00 & 0.40 & 0.00 \\
\hline 104-S3-SP02 & M/AA & & & & & & \\
\hline 104-S3-SP02 & $\mathrm{M} / \mathrm{C}$ & & & & & & \\
\hline 104-S3-SP03 & $\mathrm{Bq}$ & $1.19 \mathrm{E}+5$ & $0.00 \mathrm{E}+0$ & $0.00 \mathrm{E}+0$ & $0.00 \mathrm{E}+0$ & $5.77 \mathrm{E}+6$ & $0.00 \mathrm{E}+0$ \\
\hline 104-S3-SP03 & $\mathrm{M} / \mathrm{A}$ & 0.01 & 0.00 & 0.00 & 0.00 & 0.12 & 0.00 \\
\hline 104-S3-SP03 & M/AA & & & & & & \\
\hline 104-S3-SP03 & $\mathrm{M} / \mathrm{C}$ & & & & & & \\
\hline 104-S1-RS01 & $\mathrm{Bq}$ & $1.00 \mathrm{E}+7$ & $1.62 \mathrm{E}+5$ & $2.82 \mathrm{E}+6$ & $3.08 \mathrm{E}+6$ & $5.10 \mathrm{E}+7$ & $7.06 \mathrm{E}+4$ \\
\hline 104-S1-RS01 & $\mathrm{M} / \mathrm{A}$ & 1.04 & 1.02 & 1.03 & 1.02 & 1.05 & 0.89 \\
\hline 104-S1-RS01 & $\mathrm{M} / \mathrm{AA}$ & 1.02 & 1.00 & 1.00 & 1.00 & 1.03 & 0.87 \\
\hline 104-S1-RS01 & $\mathrm{M} / \mathrm{C}$ & 1.12 & 0.70 & 0.98 & 1.01 & 1.08 & 0.74 \\
\hline 104-S1-RS02 & $\mathrm{Bq}$ & $1.06 \mathrm{E}+7$ & $1.62 \mathrm{E}+5$ & $2.81 \mathrm{E}+6$ & $3.16 \mathrm{E}+6$ & $5.06 \mathrm{E}+7$ & $8.21 \mathrm{E}+4$ \\
\hline 104-S1-RS02 & $\mathrm{M} / \mathrm{A}$ & 1.10 & 1.02 & 1.03 & 1.05 & 1.04 & 1.04 \\
\hline 104-S1-RS02 & $\mathrm{M} / \mathrm{AA}$ & 1.05 & 0.97 & 0.98 & 1.00 & 0.99 & 0.99 \\
\hline 104-S1-RS02 & $\mathrm{M} / \mathrm{C}$ & 1.15 & 0.68 & 0.95 & 1.01 & 1.05 & 0.84 \\
\hline 104-S1-RS03 & $\mathrm{Bq}$ & $9.14 \mathrm{E}+6$ & $1.49 \mathrm{E}+5$ & $2.58 \mathrm{E}+6$ & $2.73 E+6$ & $4.54 \mathrm{E}+7$ & $7.12 \mathrm{E}+4$ \\
\hline 104-S1-RS03 & $\mathrm{M} / \mathrm{A}$ & 0.95 & 0.94 & 0.94 & 0.90 & 0.93 & 0.90 \\
\hline 104-S1-RS03 & M/AA & 1.05 & 1.04 & 1.04 & 1.00 & 1.03 & 1.00 \\
\hline 104-S1-RS03 & $\mathrm{M} / \mathrm{C}$ & 1.15 & 0.73 & 1.01 & 1.01 & 1.09 & 0.84 \\
\hline 104-S1-RS04 & $\mathrm{Bq}$ & $1.02 \mathrm{E}+7$ & $1.72 \mathrm{E}+5$ & $2.95 \mathrm{E}+6$ & $3.17 \mathrm{E}+6$ & $5.09 \mathrm{E}+7$ & $8.30 \mathrm{E}+4$ \\
\hline 104-S1-RS04 & $\mathrm{M} / \mathrm{A}$ & 1.06 & 1.08 & 1.08 & 1.05 & 1.05 & 1.05 \\
\hline 104-S1-RS04 & M/AA & 1.01 & 1.03 & 1.02 & 1.00 & 1.00 & 1.00 \\
\hline 104-S1-RS04 & $\mathrm{M} / \mathrm{C}$ & 1.10 & 0.72 & 0.99 & 1.01 & 1.05 & 0.84 \\
\hline 104-S1-RS05 & $\mathrm{Bq}$ & $9.99 \mathrm{E}+6$ & $1.72 \mathrm{E}+5$ & $2.84 \mathrm{E}+6$ & $3.10 \mathrm{E}+6$ & $5.11 \mathrm{E}+7$ & $8.27 \mathrm{E}+4$ \\
\hline 104-S1-RS05 & $\mathrm{M} / \mathrm{A}$ & 1.04 & 1.08 & 1.04 & 1.03 & 1.05 & 1.05 \\
\hline 104-S1-RS05 & M/AA & 1.01 & 1.05 & 1.01 & 1.00 & 1.02 & 1.02 \\
\hline 104-S1-RS05 & $\mathrm{M} / \mathrm{C}$ & 1.10 & 0.74 & 0.98 & 1.01 & 1.08 & 0.86 \\
\hline 104-S1-RS06 & $\mathrm{Bq}$ & $9.75 \mathrm{E}+6$ & $1.50 \mathrm{E}+5$ & $2.57 \mathrm{E}+6$ & $2.88 \mathrm{E}+6$ & $4.81 \mathrm{E}+7$ & $7.59 \mathrm{E}+4$ \\
\hline 104-S1-RS06 & $\mathrm{M} / \mathrm{A}$ & 1.01 & 0.95 & 0.94 & 0.95 & 0.99 & 0.96 \\
\hline 104-S1-RS06 & $\mathrm{M} / \mathrm{AA}$ & 1.06 & 0.99 & 0.98 & 1.00 & 1.04 & 1.00 \\
\hline 104-S1-RS06 & $\mathrm{M} / \mathrm{C}$ & 1.16 & 0.69 & 0.95 & 1.01 & 1.09 & 0.85 \\
\hline 104-S1-RS07 & $\mathrm{Bq}$ & $1.05 \mathrm{E}+7$ & $1.65 \mathrm{E}+5$ & $2.85 \mathrm{E}+6$ & $3.17 \mathrm{E}+6$ & $4.99 \mathrm{E}+7$ & $8.63 \mathrm{E}+4$ \\
\hline 104-S1-RS07 & $\mathrm{M} / \mathrm{A}$ & 1.09 & 1.04 & 1.04 & 1.05 & 1.03 & 1.09 \\
\hline 104-S1-RS07 & $\mathrm{M} / \mathrm{AA}$ & 1.03 & 0.99 & 0.99 & 1.00 & 0.97 & 1.04 \\
\hline 104-S1-RS07 & $\mathrm{M} / \mathrm{C}$ & 1.13 & 0.69 & 0.96 & 1.01 & 1.03 & 0.88 \\
\hline
\end{tabular}


Appendix Table B-2 continued. Radionuclide inventories of particles from AGR-3/4 Compact 10-4

\begin{tabular}{|c|c|c|c|c|c|c|c|}
\hline Particle & Value & ${ }^{106} \mathbf{R u}$ & ${ }^{125} \mathrm{Sb}$ & ${ }^{134} \mathrm{Cs}$ & ${ }^{137} \mathrm{Cs}$ & ${ }^{144} \mathrm{Ce}$ & ${ }^{154} \mathbf{E u}$ \\
\hline 104-S1-RS08 & $\mathrm{Bq}$ & $8.93 \mathrm{E}+6$ & $1.51 \mathrm{E}+5$ & $2.41 \mathrm{E}+6$ & $2.71 \mathrm{E}+6$ & $4.44 \mathrm{E}+7$ & $7.35 \mathrm{E}+4$ \\
\hline 104-S1-RS08 & $\mathrm{M} / \mathrm{A}$ & 0.93 & 0.95 & 0.88 & 0.90 & 0.91 & 0.93 \\
\hline 104-S1-RS08 & $\mathrm{M} / \mathrm{AA}$ & 1.03 & 1.06 & 0.98 & 1.00 & 1.02 & 1.03 \\
\hline 104-S1-RS08 & $\mathrm{M} / \mathrm{C}$ & 1.13 & 0.74 & 0.95 & 1.01 & 1.08 & 0.87 \\
\hline 104-S1-RS09 & $\mathrm{Bq}$ & $1.09 \mathrm{E}+7$ & $1.84 \mathrm{E}+5$ & $2.83 \mathrm{E}+6$ & $3.17 \mathrm{E}+6$ & $5.14 \mathrm{E}+7$ & $8.13 \mathrm{E}+4$ \\
\hline 104-S1-RS09 & $\mathrm{M} / \mathrm{A}$ & 1.13 & 1.16 & 1.03 & 1.05 & 1.06 & 1.03 \\
\hline 104-S1-RS09 & $\mathrm{M} / \mathrm{AA}$ & 1.07 & 1.10 & 0.98 & 1.00 & 1.00 & 0.98 \\
\hline 104-S1-RS09 & $\mathrm{M} / \mathrm{C}$ & 1.17 & 0.77 & 0.95 & 1.01 & 1.06 & 0.83 \\
\hline 104-S1-RS10 & $\mathrm{Bq}$ & $9.16 \mathrm{E}+6$ & $1.48 \mathrm{E}+5$ & $2.43 \mathrm{E}+6$ & $2.67 \mathrm{E}+6$ & $4.33 \mathrm{E}+7$ & $7.29 \mathrm{E}+4$ \\
\hline 104-S1-RS10 & $\mathrm{M} / \mathrm{A}$ & 0.95 & 0.93 & 0.89 & 0.89 & 0.89 & 0.92 \\
\hline 104-S1-RS10 & $\mathrm{M} / \mathrm{AA}$ & 1.07 & 1.05 & 1.00 & 1.00 & 1.01 & 1.04 \\
\hline 104-S1-RS10 & $\mathrm{M} / \mathrm{C}$ & 1.17 & 0.74 & 0.97 & 1.01 & 1.06 & 0.88 \\
\hline 104-S1-RS11 & $\mathrm{Bq}$ & $1.07 \mathrm{E}+7$ & $1.68 \mathrm{E}+5$ & $3.61 \mathrm{E}+6$ & $4.16 \mathrm{E}+6$ & $5.15 \mathrm{E}+7$ & $9.40 \mathrm{E}+4$ \\
\hline 104-S1-RS11 & $\mathrm{M} / \mathrm{A}$ & 1.11 & 1.06 & 1.32 & 1.38 & 1.06 & 1.19 \\
\hline 104-S1-RS11 & $\mathrm{M} / \mathrm{AA}$ & 0.80 & 0.77 & 0.95 & 1.00 & 0.77 & 0.86 \\
\hline 104-S1-RS11 & $\mathrm{M} / \mathrm{C}$ & 0.88 & 0.54 & 0.93 & 1.01 & 0.81 & 0.73 \\
\hline 104-S1-RS12 & $\mathrm{Bq}$ & $1.07 \mathrm{E}+7$ & $1.70 \mathrm{E}+5$ & $2.97 \mathrm{E}+6$ & $3.16 \mathrm{E}+6$ & $5.09 \mathrm{E}+7$ & $8.73 \mathrm{E}+4$ \\
\hline 104-S1-RS12 & $\mathrm{M} / \mathrm{A}$ & 1.11 & 1.07 & 1.08 & 1.05 & 1.05 & 1.10 \\
\hline 104-S1-RS12 & $\mathrm{M} / \mathrm{AA}$ & 1.06 & 1.02 & 1.03 & 1.00 & 1.00 & 1.05 \\
\hline 104-S1-RS12 & $\mathrm{M} / \mathrm{C}$ & 1.16 & 0.71 & 1.00 & 1.01 & 1.06 & 0.89 \\
\hline 104-S1-RS13 & $\mathrm{Bq}$ & $1.02 \mathrm{E}+7$ & $1.70 \mathrm{E}+5$ & $2.84 \mathrm{E}+6$ & $3.11 \mathrm{E}+6$ & $5.02 \mathrm{E}+7$ & $8.24 \mathrm{E}+4$ \\
\hline 104-S1-RS13 & $\mathrm{M} / \mathrm{A}$ & 1.06 & 1.07 & 1.04 & 1.03 & 1.03 & 1.04 \\
\hline 104-S1-RS13 & $\mathrm{M} / \mathrm{AA}$ & 1.02 & 1.04 & 1.00 & 1.00 & 1.00 & 1.01 \\
\hline 104-S1-RS13 & $\mathrm{M} / \mathrm{C}$ & 1.12 & 0.73 & 0.98 & 1.01 & 1.06 & 0.85 \\
\hline 104-S1-RS14 & $\mathrm{Bq}$ & $1.08 \mathrm{E}+7$ & $1.68 \mathrm{E}+5$ & $2.94 \mathrm{E}+6$ & $3.18 \mathrm{E}+6$ & $4.99 \mathrm{E}+7$ & $8.54 \mathrm{E}+4$ \\
\hline 104-S1-RS14 & $\mathrm{M} / \mathrm{A}$ & 1.12 & 1.06 & 1.07 & 1.05 & 1.03 & 1.08 \\
\hline 104-S1-RS14 & $\mathrm{M} / \mathrm{AA}$ & 1.06 & 1.00 & 1.02 & 1.00 & 0.97 & 1.02 \\
\hline 104-S1-RS14 & $\mathrm{M} / \mathrm{C}$ & 1.16 & 0.70 & 0.99 & 1.01 & 1.03 & 0.87 \\
\hline 104-S1-RS15 & $\mathrm{Bq}$ & $1.09 \mathrm{E}+7$ & $1.69 \mathrm{E}+5$ & $2.91 \mathrm{E}+6$ & $3.33 \mathrm{E}+6$ & $5.23 \mathrm{E}+7$ & $8.54 \mathrm{E}+4$ \\
\hline 104-S1-RS15 & $\mathrm{M} / \mathrm{A}$ & 1.13 & 1.07 & 1.06 & 1.10 & 1.08 & 1.08 \\
\hline 104-S1-RS15 & $\mathrm{M} / \mathrm{AA}$ & 1.02 & 0.97 & 0.96 & 1.00 & 0.97 & 0.98 \\
\hline 104-S1-RS15 & $\mathrm{M} / \mathrm{C}$ & 1.12 & 0.68 & 0.93 & 1.01 & 1.03 & 0.83 \\
\hline 104-S2-RS01 & $\mathrm{Bq}$ & $9.13 \mathrm{E}+6$ & $1.51 \mathrm{E}+5$ & $2.56 \mathrm{E}+6$ & $2.87 \mathrm{E}+6$ & $4.68 \mathrm{E}+7$ & $7.50 \mathrm{E}+4$ \\
\hline 104-S2-RS01 & $\mathrm{M} / \mathrm{A}$ & 0.95 & 0.95 & 0.93 & 0.95 & 0.96 & 0.95 \\
\hline 104-S2-RS01 & $\mathrm{M} / \mathrm{AA}$ & 1.00 & 1.00 & 0.98 & 1.00 & 1.01 & 1.00 \\
\hline 104-S2-RS01 & $\mathrm{M} / \mathrm{C}$ & 1.09 & 0.70 & 0.96 & 1.01 & 1.07 & 0.84 \\
\hline 104-S2-RS02 & $\mathrm{Bq}$ & $1.16 \mathrm{E}+7$ & $1.96 \mathrm{E}+5$ & $3.14 \mathrm{E}+6$ & $3.57 \mathrm{E}+6$ & $5.77 \mathrm{E}+7$ & $9.25 \mathrm{E}+4$ \\
\hline 104-S2-RS02 & $\mathrm{M} / \mathrm{A}$ & 1.20 & 1.23 & 1.14 & 1.18 & 1.19 & 1.17 \\
\hline 104-S2-RS02 & $\mathrm{M} / \mathrm{AA}$ & 1.02 & 1.04 & 0.97 & 1.00 & 1.00 & 0.99 \\
\hline 104-S2-RS02 & $\mathrm{M} / \mathrm{C}$ & 1.11 & 0.73 & 0.94 & 1.01 & 1.06 & 0.84 \\
\hline 104-S2-RS03 & $\mathrm{Bq}$ & $8.93 \mathrm{E}+6$ & $1.51 \mathrm{E}+5$ & $2.62 \mathrm{E}+6$ & $2.82 \mathrm{E}+6$ & $4.69 \mathrm{E}+7$ & $7.50 \mathrm{E}+4$ \\
\hline 104-S2-RS03 & $\mathrm{M} / \mathrm{A}$ & 0.93 & 0.95 & 0.96 & 0.94 & 0.97 & 0.95 \\
\hline 104-S2-RS03 & $\mathrm{M} / \mathrm{AA}$ & 0.99 & 1.02 & 1.02 & 1.00 & 1.03 & 1.01 \\
\hline 104-S2-RS03 & $\mathrm{M} / \mathrm{C}$ & 1.08 & 0.71 & 0.99 & 1.01 & 1.09 & 0.86 \\
\hline 104-S2-RS04 & $\mathrm{Bq}$ & $1.08 \mathrm{E}+7$ & $1.75 \mathrm{E}+5$ & $3.05 \mathrm{E}+6$ & $3.40 \mathrm{E}+6$ & $5.49 \mathrm{E}+7$ & $8.92 \mathrm{E}+4$ \\
\hline 104-S2-RS04 & $\mathrm{M} / \mathrm{A}$ & 1.12 & 1.11 & 1.11 & 1.13 & 1.13 & 1.13 \\
\hline 104-S2-RS04 & $\mathrm{M} / \mathrm{AA}$ & 1.00 & 0.98 & 0.99 & 1.00 & 1.00 & 1.00 \\
\hline 104-S2-RS04 & $\mathrm{M} / \mathrm{C}$ & 1.09 & 0.69 & 0.96 & 1.01 & 1.06 & 0.85 \\
\hline
\end{tabular}


Appendix Table B-2 continued. Radionuclide inventories of particles from AGR-3/4 Compact 10-4

\begin{tabular}{|c|c|c|c|c|c|c|c|}
\hline Particle & Value & ${ }^{106} \mathbf{R u}$ & ${ }^{125} \mathrm{Sb}$ & ${ }^{134} \mathrm{Cs}$ & ${ }^{137} \mathrm{Cs}$ & ${ }^{144} \mathrm{Ce}$ & ${ }^{154} \mathbf{E u}$ \\
\hline 104-S2-RS05 & $\mathrm{Bq}$ & $9.58 \mathrm{E}+6$ & $1.63 \mathrm{E}+5$ & $2.61 \mathrm{E}+6$ & $2.90 \mathrm{E}+6$ & $4.82 \mathrm{E}+7$ & $7.78 \mathrm{E}+4$ \\
\hline 104-S2-RS05 & $\mathrm{M} / \mathrm{A}$ & 0.99 & 1.03 & 0.95 & 0.96 & 0.99 & 0.98 \\
\hline 104-S2-RS05 & $\mathrm{M} / \mathrm{AA}$ & 1.03 & 1.07 & 0.99 & 1.00 & 1.03 & 1.02 \\
\hline 104-S2-RS05 & $\mathrm{M} / \mathrm{C}$ & 1.13 & 0.75 & 0.96 & 1.01 & 1.09 & 0.87 \\
\hline 104-S2-RS06 & $\mathrm{Bq}$ & $1.02 \mathrm{E}+7$ & $1.65 \mathrm{E}+5$ & $2.91 \mathrm{E}+6$ & $3.12 \mathrm{E}+6$ & $4.99 \mathrm{E}+7$ & $8.29 \mathrm{E}+4$ \\
\hline 104-S2-RS06 & $\mathrm{M} / \mathrm{A}$ & 1.06 & 1.04 & 1.06 & 1.03 & 1.03 & 1.05 \\
\hline 104-S2-RS06 & $\mathrm{M} / \mathrm{AA}$ & 1.02 & 1.00 & 1.03 & 1.00 & 0.99 & 1.01 \\
\hline 104-S2-RS06 & $\mathrm{M} / \mathrm{C}$ & 1.12 & 0.70 & 1.00 & 1.01 & 1.05 & 0.86 \\
\hline 104-S2-RS07 & $\mathrm{Bq}$ & $1.00 \mathrm{E}+7$ & $1.70 \mathrm{E}+5$ & $2.96 \mathrm{E}+6$ & $3.14 \mathrm{E}+6$ & $5.09 \mathrm{E}+7$ & $8.58 \mathrm{E}+4$ \\
\hline 104-S2-RS07 & $\mathrm{M} / \mathrm{A}$ & 1.04 & 1.07 & 1.08 & 1.04 & 1.05 & 1.08 \\
\hline 104-S2-RS07 & $\mathrm{M} / \mathrm{AA}$ & 1.00 & 1.03 & 1.04 & 1.00 & 1.00 & 1.04 \\
\hline 104-S2-RS07 & $\mathrm{M} / \mathrm{C}$ & 1.09 & 0.72 & 1.01 & 1.01 & 1.06 & 0.88 \\
\hline 104-S2-RS08 & $\mathrm{Bq}$ & $9.12 \mathrm{E}+6$ & $1.43 \mathrm{E}+5$ & $2.61 \mathrm{E}+6$ & $2.80 \mathrm{E}+6$ & $4.57 \mathrm{E}+7$ & $7.38 \mathrm{E}+4$ \\
\hline 104-S2-RS08 & $\mathrm{M} / \mathrm{A}$ & 0.95 & 0.90 & 0.95 & 0.93 & 0.94 & 0.93 \\
\hline 104-S2-RS08 & $\mathrm{M} / \mathrm{AA}$ & 1.02 & 0.98 & 1.03 & 1.00 & 1.01 & 1.01 \\
\hline 104-S2-RS08 & $\mathrm{M} / \mathrm{C}$ & 1.12 & 0.68 & 1.00 & 1.01 & 1.07 & 0.85 \\
\hline 104-S2-RS09 & $\mathrm{Bq}$ & $9.86 \mathrm{E}+6$ & $1.53 \mathrm{E}+5$ & $2.83 \mathrm{E}+6$ & $3.15 \mathrm{E}+6$ & $5.00 \mathrm{E}+7$ & $8.25 \mathrm{E}+4$ \\
\hline 104-S2-RS09 & $\mathrm{M} / \mathrm{A}$ & 1.02 & 0.96 & 1.03 & 1.04 & 1.03 & 1.04 \\
\hline 104-S2-RS09 & $\mathrm{M} / \mathrm{AA}$ & 0.98 & 0.92 & 0.99 & 1.00 & 0.99 & 1.00 \\
\hline 104-S2-RS09 & $\mathrm{M} / \mathrm{C}$ & 1.07 & 0.64 & 0.96 & 1.01 & 1.04 & 0.84 \\
\hline 104-S2-RS10 & $\mathrm{Bq}$ & $1.03 \mathrm{E}+7$ & $1.58 \mathrm{E}+5$ & $2.91 \mathrm{E}+6$ & $3.13 E+6$ & $5.10 \mathrm{E}+7$ & $8.19 \mathrm{E}+4$ \\
\hline 104-S2-RS10 & $\mathrm{M} / \mathrm{A}$ & 1.07 & 0.99 & 1.06 & 1.04 & 1.05 & 1.04 \\
\hline $104-S 2-R S 10$ & $\mathrm{M} / \mathrm{AA}$ & 1.03 & 0.96 & 1.02 & 1.00 & 1.01 & 1.00 \\
\hline 104-S2-RS10 & $\mathrm{M} / \mathrm{C}$ & 1.13 & 0.67 & 0.99 & 1.01 & 1.07 & 0.85 \\
\hline 104-S2-RS11 & $\mathrm{Bq}$ & $8.78 \mathrm{E}+6$ & $1.47 \mathrm{E}+5$ & $2.53 \mathrm{E}+6$ & $2.76 \mathrm{E}+6$ & $4.56 \mathrm{E}+7$ & $7.31 \mathrm{E}+4$ \\
\hline 104-S2-RS11 & $\mathrm{M} / \mathrm{A}$ & 0.91 & 0.93 & 0.92 & 0.91 & 0.94 & 0.92 \\
\hline 104-S2-RS11 & $\mathrm{M} / \mathrm{AA}$ & 1.00 & 1.01 & 1.01 & 1.00 & 1.03 & 1.01 \\
\hline 104-S2-RS11 & $\mathrm{M} / \mathrm{C}$ & 1.09 & 0.71 & 0.98 & 1.01 & 1.08 & 0.86 \\
\hline 104-S2-RS12 & $\mathrm{Bq}$ & $9.66 \mathrm{E}+6$ & $1.64 \mathrm{E}+5$ & $2.81 \mathrm{E}+6$ & $3.06 \mathrm{E}+6$ & $4.95 \mathrm{E}+7$ & $8.02 \mathrm{E}+4$ \\
\hline 104-S2-RS12 & $\mathrm{M} / \mathrm{A}$ & 1.00 & 1.03 & 1.03 & 1.01 & 1.02 & 1.01 \\
\hline 104-S2-RS12 & $\mathrm{M} / \mathrm{AA}$ & 0.99 & 1.02 & 1.01 & 1.00 & 1.00 & 1.00 \\
\hline 104-S2-RS12 & $\mathrm{M} / \mathrm{C}$ & 1.08 & 0.71 & 0.98 & 1.01 & 1.06 & 0.85 \\
\hline 104-S2-RS13 & $\mathrm{Bq}$ & $1.02 \mathrm{E}+7$ & $1.73 \mathrm{E}+5$ & $2.88 \mathrm{E}+6$ & $3.12 \mathrm{E}+6$ & $4.97 \mathrm{E}+7$ & $8.38 \mathrm{E}+4$ \\
\hline 104-S2-RS13 & $\mathrm{M} / \mathrm{A}$ & 1.06 & 1.09 & 1.05 & 1.03 & 1.02 & 1.06 \\
\hline 104-S2-RS13 & $\mathrm{M} / \mathrm{AA}$ & 1.02 & 1.06 & 1.02 & 1.00 & 0.99 & 1.03 \\
\hline 104-S2-RS13 & $\mathrm{M} / \mathrm{C}$ & 1.12 & 0.74 & 0.99 & 1.01 & 1.05 & 0.87 \\
\hline 104-S2-RS14 & $\mathrm{Bq}$ & $1.06 \mathrm{E}+7$ & $1.80 \mathrm{E}+5$ & $3.08 \mathrm{E}+6$ & $3.32 \mathrm{E}+6$ & $5.30 \mathrm{E}+7$ & $8.97 \mathrm{E}+4$ \\
\hline 104-S2-RS14 & $\mathrm{M} / \mathrm{A}$ & 1.10 & 1.13 & 1.12 & 1.10 & 1.09 & 1.13 \\
\hline 104-S2-RS14 & $\mathrm{M} / \mathrm{AA}$ & 1.00 & 1.03 & 1.02 & 1.00 & 0.99 & 1.03 \\
\hline 104-S2-RS14 & $\mathrm{M} / \mathrm{C}$ & 1.10 & 0.72 & 0.99 & 1.01 & 1.05 & 0.87 \\
\hline 104-S2-RS15 & $\mathrm{Bq}$ & $9.69 \mathrm{E}+6$ & $1.67 \mathrm{E}+5$ & $2.85 \mathrm{E}+6$ & $3.13 \mathrm{E}+6$ & $5.23 \mathrm{E}+7$ & $8.44 \mathrm{E}+4$ \\
\hline 104-S2-RS15 & $\mathrm{M} / \mathrm{A}$ & 1.00 & 1.05 & 1.04 & 1.04 & 1.07 & 1.07 \\
\hline 104-S2-RS15 & $\mathrm{M} / \mathrm{AA}$ & 0.97 & 1.02 & 1.00 & 1.00 & 1.04 & 1.03 \\
\hline 104-S2-RS15 & $\mathrm{M} / \mathrm{C}$ & 1.06 & 0.71 & 0.97 & 1.01 & 1.10 & 0.87 \\
\hline 104-S3-RS01 & $\mathrm{Bq}$ & $8.42 \mathrm{E}+6$ & $1.37 \mathrm{E}+5$ & $2.47 \mathrm{E}+6$ & $2.72 \mathrm{E}+6$ & $4.51 \mathrm{E}+7$ & $7.02 \mathrm{E}+4$ \\
\hline 104-S3-RS01 & $\mathrm{M} / \mathrm{A}$ & 0.87 & 0.87 & 0.90 & 0.90 & 0.93 & 0.89 \\
\hline 104-S3-RS01 & $\mathrm{M} / \mathrm{AA}$ & 0.97 & 0.96 & 1.00 & 1.00 & 1.03 & 0.98 \\
\hline 104-S3-RS01 & $\mathrm{M} / \mathrm{C}$ & 1.06 & 0.67 & 0.97 & 1.01 & 1.09 & 0.83 \\
\hline
\end{tabular}


Appendix Table B-2 continued. Radionuclide inventories of particles from AGR-3/4 Compact 10-4

\begin{tabular}{|c|c|c|c|c|c|c|c|}
\hline Particle & Value & ${ }^{106} \mathbf{R u}$ & ${ }^{125} \mathrm{Sb}$ & ${ }^{134} \mathrm{Cs}$ & ${ }^{137} \mathrm{Cs}$ & ${ }^{144} \mathrm{Ce}$ & ${ }^{154} \mathbf{E u}$ \\
\hline 104-S3-RS02 & $\mathrm{Bq}$ & $8.30 \mathrm{E}+6$ & $1.36 \mathrm{E}+5$ & $2.42 \mathrm{E}+6$ & $2.62 \mathrm{E}+6$ & $4.36 \mathrm{E}+7$ & $7.03 \mathrm{E}+4$ \\
\hline 104-S3-RS02 & $\mathrm{M} / \mathrm{A}$ & 0.86 & 0.86 & 0.88 & 0.87 & 0.90 & 0.89 \\
\hline 104-S3-RS02 & $\mathrm{M} / \mathrm{AA}$ & 0.99 & 0.99 & 1.02 & 1.00 & 1.03 & 1.02 \\
\hline 104-S3-RS02 & $\mathrm{M} / \mathrm{C}$ & 1.09 & 0.69 & 0.99 & 1.01 & 1.09 & 0.87 \\
\hline 104-S3-RS03 & $\mathrm{Bq}$ & $9.57 \mathrm{E}+6$ & $1.57 \mathrm{E}+5$ & $2.76 \mathrm{E}+6$ & $3.04 \mathrm{E}+6$ & $4.95 \mathrm{E}+7$ & $7.98 \mathrm{E}+4$ \\
\hline 104-S3-RS03 & $\mathrm{M} / \mathrm{A}$ & 0.99 & 0.99 & 1.01 & 1.01 & 1.02 & 1.01 \\
\hline 104-S3-RS03 & $\mathrm{M} / \mathrm{AA}$ & 0.98 & 0.98 & 1.00 & 1.00 & 1.01 & 1.00 \\
\hline 104-S3-RS03 & $\mathrm{M} / \mathrm{C}$ & 1.08 & 0.68 & 0.97 & 1.01 & 1.07 & 0.85 \\
\hline 104-S3-RS04 & $\mathrm{Bq}$ & $1.01 \mathrm{E}+7$ & $1.77 \mathrm{E}+5$ & $3.02 \mathrm{E}+6$ & $3.32 \mathrm{E}+6$ & $5.39 \mathrm{E}+7$ & $8.87 \mathrm{E}+4$ \\
\hline 104-S3-RS04 & $\mathrm{M} / \mathrm{A}$ & 1.04 & 1.11 & 1.10 & 1.10 & 1.11 & 1.12 \\
\hline 104-S3-RS04 & $\mathrm{M} / \mathrm{AA}$ & 0.95 & 1.01 & 1.00 & 1.00 & 1.01 & 1.02 \\
\hline 104-S3-RS04 & $\mathrm{M} / \mathrm{C}$ & 1.04 & 0.71 & 0.97 & 1.01 & 1.07 & 0.86 \\
\hline 104-S3-RS05 & $\mathrm{Bq}$ & $8.01 \mathrm{E}+6$ & $1.36 \mathrm{E}+5$ & $2.33 \mathrm{E}+6$ & $2.60 \mathrm{E}+6$ & $4.33 \mathrm{E}+7$ & $6.66 \mathrm{E}+4$ \\
\hline 104-S3-RS05 & $\mathrm{M} / \mathrm{A}$ & 0.83 & 0.86 & 0.85 & 0.86 & 0.89 & 0.84 \\
\hline 104-S3-RS05 & $\mathrm{M} / \mathrm{AA}$ & 0.96 & 0.99 & 0.99 & 1.00 & 1.03 & 0.98 \\
\hline 104-S3-RS05 & $\mathrm{M} / \mathrm{C}$ & 1.05 & 0.69 & 0.96 & 1.01 & 1.09 & 0.83 \\
\hline 104-S3-RS06 & $\mathrm{Bq}$ & $9.85 \mathrm{E}+6$ & $1.55 \mathrm{E}+5$ & $2.84 \mathrm{E}+6$ & $3.18 \mathrm{E}+6$ & $4.95 \mathrm{E}+7$ & $8.12 \mathrm{E}+4$ \\
\hline 104-S3-RS06 & $\mathrm{M} / \mathrm{A}$ & 1.02 & 0.98 & 1.04 & 1.05 & 1.02 & 1.03 \\
\hline 104-S3-RS06 & $\mathrm{M} / \mathrm{AA}$ & 0.97 & 0.93 & 0.98 & 1.00 & 0.97 & 0.98 \\
\hline 104-S3-RS06 & $\mathrm{M} / \mathrm{C}$ & 1.06 & 0.65 & 0.95 & 1.01 & 1.02 & 0.82 \\
\hline 104-S3-RS07 & $\mathrm{Bq}$ & $8.66 \mathrm{E}+6$ & $1.35 \mathrm{E}+5$ & $2.50 \mathrm{E}+6$ & $2.79 \mathrm{E}+6$ & $4.65 \mathrm{E}+7$ & $7.20 \mathrm{E}+4$ \\
\hline 104-S3-RS07 & $\mathrm{M} / \mathrm{A}$ & 0.90 & 0.85 & 0.91 & 0.93 & 0.96 & 0.91 \\
\hline 104-S3-RS07 & $\mathrm{M} / \mathrm{AA}$ & 0.97 & 0.92 & 0.99 & 1.00 & 1.03 & 0.98 \\
\hline 104-S3-RS07 & $\mathrm{M} / \mathrm{C}$ & 1.06 & 0.64 & 0.96 & 1.01 & 1.09 & 0.83 \\
\hline 104-S3-RS08 & $\mathrm{Bq}$ & $9.30 \mathrm{E}+6$ & $1.64 \mathrm{E}+5$ & $2.82 \mathrm{E}+6$ & $3.04 \mathrm{E}+6$ & $5.01 \mathrm{E}+7$ & $8.09 \mathrm{E}+4$ \\
\hline 104-S3-RS08 & $\mathrm{M} / \mathrm{A}$ & 0.96 & 1.03 & 1.03 & 1.01 & 1.03 & 1.02 \\
\hline 104-S3-RS08 & $\mathrm{M} / \mathrm{AA}$ & 0.96 & 1.03 & 1.02 & 1.00 & 1.02 & 1.02 \\
\hline 104-S3-RS08 & $\mathrm{M} / \mathrm{C}$ & 1.05 & 0.72 & 0.99 & 1.01 & 1.08 & 0.86 \\
\hline 104-S3-RS09 & $\mathrm{Bq}$ & $8.44 \mathrm{E}+6$ & $1.36 \mathrm{E}+5$ & $2.54 \mathrm{E}+6$ & $2.76 \mathrm{E}+6$ & $4.47 \mathrm{E}+7$ & $7.32 \mathrm{E}+4$ \\
\hline 104-S3-RS09 & $\mathrm{M} / \mathrm{A}$ & 0.87 & 0.86 & 0.93 & 0.91 & 0.92 & 0.93 \\
\hline 104-S3-RS09 & $\mathrm{M} / \mathrm{AA}$ & 0.96 & 0.94 & 1.01 & 1.00 & 1.01 & 1.01 \\
\hline 104-S3-RS09 & $\mathrm{M} / \mathrm{C}$ & 1.05 & 0.66 & 0.98 & 1.01 & 1.06 & 0.86 \\
\hline 104-S3-RS10 & $\mathrm{Bq}$ & $8.89 E+6$ & $1.57 \mathrm{E}+5$ & $2.57 \mathrm{E}+6$ & $2.90 \mathrm{E}+6$ & $4.58 \mathrm{E}+7$ & $7.44 \mathrm{E}+4$ \\
\hline 104-S3-RS10 & $\mathrm{M} / \mathrm{A}$ & 0.92 & 0.99 & 0.94 & 0.96 & 0.94 & 0.94 \\
\hline 104-S3-RS10 & $\mathrm{M} / \mathrm{AA}$ & 0.96 & 1.03 & 0.97 & 1.00 & 0.98 & 0.98 \\
\hline 104-S3-RS10 & $\mathrm{M} / \mathrm{C}$ & 1.05 & 0.72 & 0.94 & 1.01 & 1.03 & 0.83 \\
\hline 104-S3-RS11 & $\mathrm{Bq}$ & $8.81 \mathrm{E}+6$ & $1.53 \mathrm{E}+5$ & $2.48 \mathrm{E}+6$ & $2.76 \mathrm{E}+6$ & $4.41 \mathrm{E}+7$ & $7.23 \mathrm{E}+4$ \\
\hline 104-S3-RS11 & $\mathrm{M} / \mathrm{A}$ & 0.91 & 0.96 & 0.90 & 0.91 & 0.91 & 0.91 \\
\hline 104-S3-RS11 & $\mathrm{M} / \mathrm{AA}$ & 1.00 & 1.05 & 0.99 & 1.00 & 0.99 & 1.00 \\
\hline 104-S3-RS1 1 & $\mathrm{M} / \mathrm{C}$ & 1.09 & 0.74 & 0.96 & 1.01 & 1.05 & 0.85 \\
\hline 104-S3-RS12 & $\mathrm{Bq}$ & $9.19 \mathrm{E}+6$ & $1.55 \mathrm{E}+5$ & $2.72 \mathrm{E}+6$ & $2.98 \mathrm{E}+6$ & $4.80 \mathrm{E}+7$ & $7.88 \mathrm{E}+4$ \\
\hline 104-S3-RS12 & $\mathrm{M} / \mathrm{A}$ & 0.95 & 0.98 & 0.99 & 0.99 & 0.99 & 1.00 \\
\hline 104-S3-RS12 & $\mathrm{M} / \mathrm{AA}$ & 0.96 & 0.99 & 1.00 & 1.00 & 1.00 & 1.01 \\
\hline 104-S3-RS12 & $\mathrm{M} / \mathrm{C}$ & 1.05 & 0.69 & 0.98 & 1.01 & 1.06 & 0.85 \\
\hline 104-S3-RS13 & $\mathrm{Bq}$ & $8.02 \mathrm{E}+6$ & $1.28 \mathrm{E}+5$ & $2.27 \mathrm{E}+6$ & $2.49 \mathrm{E}+6$ & $4.10 \mathrm{E}+7$ & $6.61 \mathrm{E}+4$ \\
\hline 104-S3-RS13 & $\mathrm{M} / \mathrm{A}$ & 0.83 & 0.81 & 0.83 & 0.82 & 0.84 & 0.84 \\
\hline 104-S3-RS13 & $\mathrm{M} / \mathrm{AA}$ & 1.01 & 0.98 & 1.01 & 1.00 & 1.02 & 1.01 \\
\hline 104-S3-RS13 & $\mathrm{M} / \mathrm{C}$ & 1.10 & 0.68 & 0.98 & 1.01 & 1.08 & 0.86 \\
\hline
\end{tabular}


Appendix Table B-2 continued. Radionuclide inventories of particles from AGR-3/4 Compact 10-4

\begin{tabular}{lccccccc}
\hline Particle & Value & ${ }^{\mathbf{1 0 6}} \mathbf{R u}$ & ${ }^{\mathbf{1 2 5}} \mathbf{S b}$ & ${ }^{\mathbf{1 3 4}} \mathbf{C s}$ & ${ }^{\mathbf{1 3 7}} \mathbf{C s}$ & ${ }^{\mathbf{1 4 4}} \mathbf{C e}$ & ${ }^{\mathbf{1 5 4}} \mathbf{E u}$ \\
\hline 104-S3-RS14 & $\mathrm{Bq}$ & $8.56 \mathrm{E}+6$ & $1.49 \mathrm{E}+5$ & $2.40 \mathrm{E}+6$ & $2.68 \mathrm{E}+6$ & $4.46 \mathrm{E}+7$ & $6.96 \mathrm{E}+4$ \\
$104-S 3-R S 14$ & $\mathrm{M} / \mathrm{A}$ & 0.89 & 0.94 & 0.87 & 0.89 & 0.92 & 0.88 \\
$104-S 3-R S 14$ & $\mathrm{M} / \mathrm{AA}$ & 1.00 & 1.06 & 0.98 & 1.00 & 1.03 & 0.99 \\
$104-S 3-R S 14$ & $\mathrm{M} / \mathrm{C}$ & 1.09 & 0.74 & 0.96 & 1.01 & 1.09 & 0.84 \\
$104-S 3-R S 15$ & $\mathrm{~Bq}$ & $9.01 \mathrm{E}+6$ & $1.48 \mathrm{E}+5$ & $2.56 \mathrm{E}+6$ & $2.86 \mathrm{E}+6$ & $4.59 \mathrm{E}+7$ & $7.38 \mathrm{E}+4$ \\
104-S3-RS15 & $\mathrm{M} / \mathrm{A}$ & 0.93 & 0.93 & 0.93 & 0.95 & 0.94 & 0.93 \\
104-S3-RS15 & $\mathrm{M} / \mathrm{AA}$ & 0.99 & 0.98 & 0.99 & 1.00 & 1.00 & 0.99 \\
104-S3-RS15 & $\mathrm{M} / \mathrm{C}$ & 1.08 & 0.69 & 0.96 & 1.01 & 1.05 & 0.83 \\
\hline Maximum & $\mathrm{Bq}$ & $1.16 \mathrm{E}+7$ & $1.96 \mathrm{E}+5$ & $3.61 \mathrm{E}+6$ & $4.16 \mathrm{E}+6$ & $5.77 \mathrm{E}+7$ & $9.40 \mathrm{E}+4$ \\
Maximum & $\mathrm{M} / \mathrm{A}$ & 1.20 & 1.23 & 1.32 & 1.38 & 1.19 & 1.19 \\
Maximum & $\mathrm{M} / \mathrm{AA}$ & 1.07 & 1.10 & 1.04 & 1.00 & 1.04 & 1.05 \\
Maximum & $\mathrm{M} / \mathrm{C}$ & 1.17 & 0.77 & 1.01 & 1.01 & 1.10 & 0.89 \\
Minimum & $\mathrm{Bq}$ & $8.01 \mathrm{E}+6$ & $1.28 \mathrm{E}+5$ & $2.27 \mathrm{E}+6$ & $2.49 \mathrm{E}+6$ & $4.10 \mathrm{E}+7$ & $6.61 \mathrm{E}+4$ \\
Minimum & $\mathrm{M} / \mathrm{A}$ & 0.83 & 0.81 & 0.83 & 0.82 & 0.84 & 0.84 \\
Minimum & $\mathrm{M} / \mathrm{AA}$ & 0.80 & 0.77 & 0.95 & 1.00 & 0.77 & 0.86 \\
Minimum & $\mathrm{M} / \mathrm{C}$ & 0.88 & 0.54 & 0.93 & 1.01 & 0.81 & 0.73 \\
Mean & $\mathrm{Bq}$ & $9.65 \mathrm{E}+6$ & $1.59 \mathrm{E}+5$ & $2.74 \mathrm{E}+6$ & $3.02 \mathrm{E}+6$ & $4.86 \mathrm{E}+7$ & $7.91 \mathrm{E}+4$ \\
Mean & $\mathrm{M} / \mathrm{A}$ & 1.00 & 1.00 & 1.00 & 1.00 & 1.00 & 1.00 \\
Mean & $\mathrm{M} / \mathrm{AA}$ & 1.00 & 1.00 & 1.00 & 1.00 & 1.00 & 1.00 \\
Mean & $\mathrm{M} / \mathrm{C}$ & 1.10 & 0.70 & 0.97 & 1.01 & 1.06 & 0.85 \\
SD & $\mathrm{Bq}$ & $9.1 \%$ & $9.1 \%$ & $9.3 \%$ & $9.8 \%$ & $7.2 \%$ & $8.9 \%$ \\
SD & $\mathrm{M} / \mathrm{A}$ & $9.1 \%$ & $9.1 \%$ & $9.3 \%$ & $9.8 \%$ & $7.2 \%$ & $8.9 \%$ \\
SD & $\mathrm{M} / \mathrm{AA}$ & $4.5 \%$ & $5.4 \%$ & $2.1 \%$ & $0.0 \%$ & $4.1 \%$ & $3.5 \%$ \\
SD & $\mathrm{M} / \mathrm{C}$ & $4.5 \%$ & $5.4 \%$ & $2.1 \%$ & $0.0 \%$ & $4.1 \%$ & $3.5 \%$ \\
\hline
\end{tabular}




\section{APPENDIX C. CALCULATED INVENTORIES}

The tables in this appendix provide the calculated inventories for select actinides and fission products (both radionuclides and stable nuclides) that were used to calculate values reported herein (i.e., compact fraction and M/C as described in Section 2). Calculated inventories were estimated via physics depletion calculations using the Oak Ridge Isotope Generation and Depletion (ORIGEN2) code (Croff 1983; Ludwig and Croff 2002), the Monte Carlo N-Particle Transport (MCNP) code (X-5 Monte Carlo Team 2003), and Jim Sterbentz's MCNP-ORIGEN2 coupled utility program (JMOCUP) and software extraction modules (Sterbentz 2015).

Appendix Table C-1. Calculated inventories of select actinides one year after EOL

\begin{tabular}{lcccccc}
\hline Compact & Value & ${ }^{235} \mathbf{U}$ & ${ }^{\mathbf{2 3}} \mathbf{U}$ & ${ }^{238} \mathbf{U}$ & ${ }^{239} \mathbf{P u}$ & ${ }^{240} \mathbf{P u}$ \\
\hline AGR-3/4 1-4 & moles/compact & $2.3480 \mathrm{E}-4$ & $2.6620 \mathrm{E}-5$ & $1.4755 \mathrm{E}-3$ & $1.8410 \mathrm{E}-5$ & $3.7130 \mathrm{E}-6$ \\
AGR-3/4 1-4 & $\mu \mathrm{g} /$ compact & $5.5188 \mathrm{E}+4$ & $6.2835 \mathrm{E}+3$ & $3.5124 \mathrm{E}+5$ & $4.4009 \mathrm{E}+3$ & $8.9132 \mathrm{E}+2$ \\
AGR-3/4 10-4 & moles/compact & $1.5314 \mathrm{E}-4$ & $3.9090 \mathrm{E}-5$ & $1.4474 \mathrm{E}-3$ & $2.1420 \mathrm{E}-5$ & $7.0290 \mathrm{E}-6$ \\
AGR-3/4 10-4 & $\mu \mathrm{g} /$ compact & $3.5995 \mathrm{E}+4$ & $9.2270 \mathrm{E}+3$ & $3.4456 \mathrm{E}+5$ & $5.1205 \mathrm{E}+3$ & $1.6873 \mathrm{E}+3$ \\
\hline
\end{tabular}

Appendix Table C-2. Calculated inventories of select stable nuclides one year after EOL

\begin{tabular}{lcccccc}
\hline Compact & Value & ${ }^{105} \mathbf{P d}$ & ${ }^{109} \mathbf{A g}$ & ${ }^{133} \mathbf{C s}$ & ${ }^{139} \mathbf{L a}$ & ${ }^{140} \mathbf{C e}$ \\
\hline AGR-3/4 1-4 & moles/compact & $1.6701 \mathrm{E}-6$ & $1.9780 \mathrm{E}-7$ & $8.4730 \mathrm{E}-6$ & $8.3450 \mathrm{E}-6$ & $8.0160 \mathrm{E}-6$ \\
AGR-3/4 1-4 & $\mu \mathrm{g} /$ compact & $1.7520 \mathrm{E}+2$ & $2.1541 \mathrm{E}+1$ & $1.1261 \mathrm{E}+3$ & $1.1592 \mathrm{E}+3$ & $1.1215 \mathrm{E}+3$ \\
AGR-3/4 10-4 & moles/compact & $3.0090 \mathrm{E}-6$ & $4.6430 \mathrm{E}-7$ & $1.3616 \mathrm{E}-5$ & $1.3793 \mathrm{E}-5$ & $1.3356 \mathrm{E}-5$ \\
AGR-3/4 10-4 & $\mu \mathrm{g} /$ compact & $3.1566 \mathrm{E}+2$ & $5.0564 \mathrm{E}+1$ & $1.8096 \mathrm{E}+3$ & $1.9159 \mathrm{E}+3$ & $1.8686 \mathrm{E}+3$ \\
\hline
\end{tabular}

Appendix Table C-2 continued. Calculated inventories of select stable nuclides one year after EOL

\begin{tabular}{lcccccc}
\hline Compact & Value & ${ }^{\mathbf{1 4 1}} \mathbf{P r}$ & ${ }^{\mathbf{1 4 6}} \mathbf{N d}$ & ${ }^{\mathbf{1 5 2}} \mathbf{S m}$ & ${ }^{\mathbf{1 5 3}} \mathbf{E u}$ & ${ }^{\mathbf{1 5 6}} \mathbf{G d}$ \\
\hline AGR-3/4 1-4 & moles/compact & $7.5450 \mathrm{E}-6$ & $4.6260 \mathrm{E}-6$ & $7.4420 \mathrm{E}-7$ & $3.8610 \mathrm{E}-7$ & $9.6830 \mathrm{E}-8$ \\
AGR-3/4 1-4 & $\mu \mathrm{g} /$ compact & $1.0631 \mathrm{E}+3$ & $6.7499 \mathrm{E}+2$ & $1.1306 \mathrm{E}+2$ & $5.9043 \mathrm{E}+1$ & $1.5098 \mathrm{E}+1$ \\
AGR-3/4 10-4 & moles/compact & $1.2465 \mathrm{E}-5$ & $7.9290 \mathrm{E}-6$ & $1.1948 \mathrm{E}-6$ & $8.3420 \mathrm{E}-7$ & $2.8340 \mathrm{E}-7$ \\
AGR-3/4 10-4 & $\mu \mathrm{g} /$ compact & $1.7564 \mathrm{E}+3$ & $1.1569 \mathrm{E}+3$ & $1.8151 \mathrm{E}+2$ & $1.2757 \mathrm{E}+2$ & $4.4188 \mathrm{E}+1$ \\
\hline
\end{tabular}


Appendix Table C-3. Calculated inventories of select radionuclides one day after EOL

\begin{tabular}{lcccccc}
\hline Compact & Value & ${ }^{\mathbf{8 5}} \mathbf{K r}$ & ${ }^{\mathbf{9 0}} \mathbf{S r}$ & ${ }^{\mathbf{1 0 6}} \mathbf{R u}$ & ${ }^{\mathbf{1 1 0}} \mathbf{A g}$ & ${ }^{\mathbf{1 2 5}} \mathbf{S b}$ \\
\hline AGR-3/4 1-4 & moles/compact & $3.1330 \mathrm{E}-7$ & $6.8510 \mathrm{E}-6$ & $5.9420 \mathrm{E}-7$ & $6.1410 \mathrm{E}-10$ & $5.0290 \mathrm{E}-8$ \\
AGR-3/4 1-4 & Bq/compact & $3.8530 \mathrm{E}+8$ & $3.1477 \mathrm{E}+9$ & $7.7212 \mathrm{E}+9$ & $1.1879 \mathrm{E}+7$ & $2.4115 \mathrm{E}+8$ \\
AGR-3/4 1-4 & Bq/particle & $2.0088 \mathrm{E}+5$ & $1.6411 \mathrm{E}+6$ & $4.0257 \mathrm{E}+6$ & $6.1934 \mathrm{E}+3$ & $1.2573 \mathrm{E}+5$ \\
AGR-3/4 10-4 & moles/compact & $5.0560 \mathrm{E}-7$ & $1.1019 \mathrm{E}-5$ & $1.3014 \mathrm{E}-6$ & $2.6390 \mathrm{E}-9$ & $9.0770 \mathrm{E}-8$ \\
AGR-3/4 10-4 & Bq/compact & $6.2179 \mathrm{E}+8$ & $5.0627 \mathrm{E}+9$ & $1.6911 \mathrm{E}+10$ & $5.1048 \mathrm{E}+7$ & $4.3526 \mathrm{E}+8$ \\
AGR-3/4 10-4 & Bq/particle & $3.2418 \mathrm{E}+5$ & $2.6396 \mathrm{E}+6$ & $8.8169 \mathrm{E}+6$ & $2.6615 \mathrm{E}+4$ & $2.2693 \mathrm{E}+5$ \\
\hline
\end{tabular}

Appendix Table C-3 continued. Calculated inventories of select radionuclides one day after EOL

\begin{tabular}{lcccccc}
\hline Compact & Value & ${ }^{134} \mathbf{C s}$ & ${ }^{137} \mathbf{C s}$ & ${ }^{144} \mathbf{C e}$ & ${ }^{154} \mathbf{E u}$ & ${ }^{155} \mathbf{E u}$ \\
\hline AGR-3/4 1-4 & moles/compact & $2.7900 \mathrm{E}-7$ & $7.7840 \mathrm{E}-6$ & $3.2630 \mathrm{E}-6$ & $3.9960 \mathrm{E}-8$ & $2.1080 \mathrm{E}-8$ \\
AGR-3/4 1-4 & Bq/compact & $1.7870 \mathrm{E}+9$ & $3.4230 \mathrm{E}+9$ & $5.5331 \mathrm{E}+10$ & $6.1456 \mathrm{E}+7$ & $5.8666 \mathrm{E}+7$ \\
AGR-3/4 1-4 & Bq/particle & $9.3170 \mathrm{E}+5$ & $1.7847 \mathrm{E}+6$ & $2.8849 \mathrm{E}+7$ & $3.2041 \mathrm{E}+4$ & $3.0587 \mathrm{E}+4$ \\
AGR-3/4 10-4 & moles/compact & $8.4560 \mathrm{E}-7$ & $1.3031 \mathrm{E}-5$ & $5.2060 \mathrm{E}-6$ & $1.1672 \mathrm{E}-7$ & $4.5150 \mathrm{E}-8$ \\
AGR-3/4 10-4 & Bq/compact & $5.4161 \mathrm{E}+9$ & $5.7304 \mathrm{E}+9$ & $8.8279 \mathrm{E}+10$ & $1.7951 \mathrm{E}+8$ & $1.2565 \mathrm{E}+8$ \\
AGR-3/4 10-4 & Bq/particle & $2.8238 \mathrm{E}+6$ & $2.9877 \mathrm{E}+6$ & $4.6027 \mathrm{E}+7$ & $9.3591 \mathrm{E}+4$ & $6.5513 \mathrm{E}+4$ \\
\hline
\end{tabular}

